\author{
Universidade de São Paulo \\ Faculdade de Filosofia, Letras e CiênCias Humanas \\ DePartamento de TeOria Literária e Literatura CoMParada
}

NILSON JOAQUIM DA SILVA

\title{
RIOBALDO, SIRUIZ E O CANTO DAS ÁGUAS \\ Nos versos da canção, o destino (de)cifrado de um baldo narrador-rio
}

VERSÃO CORRIGIDA 


\title{
NILSON JOAQUIM DA SILVA
}

\section{RIOBALDO, SIRUIZ E O CANTO DAS ÁGUAS}

Nos versos da canção, o destino (de)cifrado de um baldo narrador-rio

\author{
VERSÃO CORRIGIDA
}

Dissertação apresentada à Faculdade de Filosofia, Letras e Ciências Humanas da Universidade de São Paulo para obtenção do título de Mestre em Teoria Literária e Literatura Comparada.

Área de Concentração: Teoria Literária e Literatura Comparada.

Orientador: Prof. Dr. Marcus Vinícius Mazzari. 
Nome: SILVA, Nilson Joaquim da

Título: Riobaldo, Siruiz e o canto das águas: nos versos da canção, o destino (de)cifrado de um baldo narrador-rio

Dissertação apresentada à Faculdade de Filosofia, Letras e Ciências Humanas da Universidade de São Paulo para obtenção do título de Mestre em Teoria Literária e Literatura Comparada.

Aprovado em:

Banca Examinadora:

Prof. Dr.:

Instituição:

Julgamento:

Assinatura:

Prof. Dr.

Instituição:

Julgamento:

Assinatura:

Prof. Dr.:

Instituição:

Julgamento:

Assinatura: 
Para Rê e João Pedro, encontro das águas. 


\section{AGRADECIMENTOS}

Minha gratidão a todos, familiares e amigos, pelo incentivo.

Ao Prof. Dr. Marcus Vinícius Mazzari, mestre nas palavras e no silêncio, pela orientação e pela gentileza no compartilhar de seu conhecimento.

Ao Prof. Dr. Murilo Marcondes de Moura, à Prof. Dra. Yudith Rosenbaum e ao Prof. Dr. Alberto Martins, pela aferição de rumos, pelo partilhar da poesia e da sabedoria, pela plena presença.

À CAPES, pela concessão da bolsa de estudos que muito contribuiu para a elaboração deste trabalho.

À Nilza Aparecida Tabai e à Regina Celi Quarenta, pelas leituras minuciosas, pelo carinho, pelo diálogo.

Aos professores e colegas, pela enriquecedora troca de experiências.

A Luiz de Mattos Alves e à equipe da secretaria, pelo apoio e pela atenção.

Ao meu pequeno João Pedro, concebido junto com estas linhas, pelos sorrisos, pelo olhar já tão atento e pelo alento em meio à travessia.

À minha esposa Rê, pela dádiva, pela luz.

À Brisa e ao Dom, terceira margem. 


\section{RESUMO}

Para Davi Arrigucci Jr., em “O mundo misturado: romance e experiência em Guimarães Rosa”, a canção de Siruiz contém, "cifrada em suas palavras enigmáticas", o "destino de Riobaldo". O propósito deste estudo é, a partir da análise mitopoética dos versos dessa canção e dos que o próprio protagonista-narrador do Grande sertão: veredas compôs para complementá-la, tentar decifrar o "destino individual" do herói problemático Riobaldo e os plurais e dialéticos sentidos de sua travessia. Para tanto, embasados na fortuna crítica e no acervo de leituras, depoimentos e cartas de Rosa, buscamos analisar comparativamente o motivo da canção no romance, em algumas das demais obras do autor, e em clássicos como a Teogonia, de Hesíodo, a Vita Nuova e A Divina Comédia, de Dante Alighieri, Os anos de aprendizado de Wilhelm Meister e o Fausto, de Goethe, a obra inacabada Heinrich von Ofterdingen, de Novalis, além de levantar alusões à Bíblia, à tradição fáustica e à tradição romanesca medieval que, ao que tudo indica, também serviram de inspiração e intertexto para Rosa na gênese e nos desígnios da canção de Siruiz e de seus contextos de representação.

Palavras-chave: Grande sertão: veredas; Canção de Siruiz; Teogonia; Pacto fáustico. 


\begin{abstract}
According to Arrigucci Jr., in "The Mixed World - Romance and Experience in Guimarães Rosa”, the song of Siruiz contains, "encrypted in his enigmatic words", the "destiny of Riobaldo". The purpose of this study is, from the mythopoetic analysis of the verses of this song and of those that the protagonist-narrator of Grande Sertão: Veredas composed in order to complement it, try to decipher the "individual destiny" of the problematical hero Riobaldo and the plurals and dialecticals senses of his trajectory. In order to do so, we sought, based on readings acquis and critiques, as well as on depositions and letters from Rosa, to analyze comparatively the motif of the song not only in the romance but also in some other works of the author, as well as in other classics, such as Theogony, by Hesiod, Vita Nuova and The Divine Comedy, by Dante Alighieri, Wilhelm Meister's Apprenticeship and the Faust, by Goethe, and the incomplete novel Heinrich von Ofterdingen, by Novalis. In addition, we sought to raise allusions to the Bible, to the Faustian traditions and to the medieval novelistic tradition, which, it seems, were also used as inspiration and intertext by Rosa on Siruiz song's genesis and designs, as well as on its contexts of representation.
\end{abstract}

Keywords. Grande Sertão: Veredas; Song of Siruiz; Theogony; Faustian pact. 


\section{Sumário}

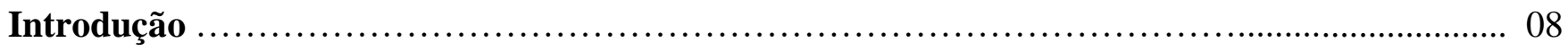

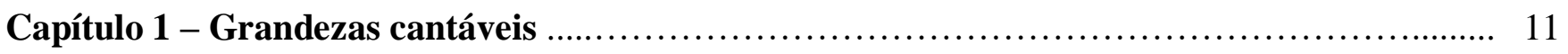

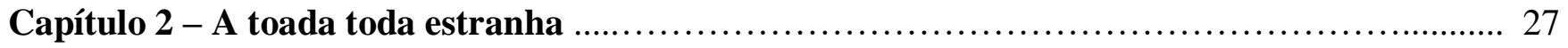

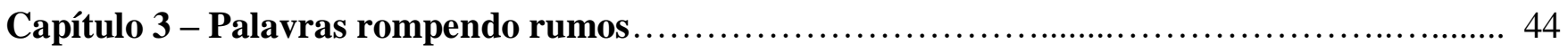

Capítulo 4 - Canção de Siruiz, neblina de Riobaldo ........................................................ 63

Capítulo 5 - Da matéria vertente às vertentes do viver..................................................... 89

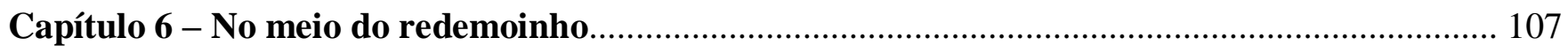

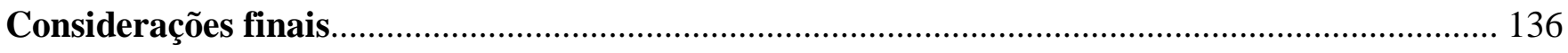

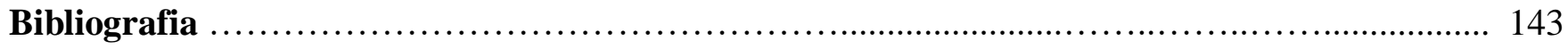




\section{INTRODUÇÃO}

Essa vida está cheia de ocultos caminhos. Se o senhor souber, sabe; não sabendo, não me entenderá.

(Grande sertão: veredas, Guimarães Rosa) ${ }^{1}$

Davi Arrigucci Jr., em "O mundo misturado: romance e experiência em Guimarães Rosa"2, chama a atenção para a importância da canção de Siruiz no decifrar da "travessia individual" de Riobaldo e da "vasta poesia épica do sertão" no Grande sertão de Rosa. Para Arrigucci, a balada contém, "cifrada em suas palavras enigmáticas", o "destino de Riobaldo". O objetivo desta pesquisa é, a partir da análise mitopoética e poético-literária dos versos dessa canção, em perspectiva comparada com a tradição e com a própria obra de Rosa, e embasados na fortuna crítica e nos depoimentos, cartas e entrevistas do autor, além de seu acervo de leituras ${ }^{3}$, trazer nova luz à sua decifração e à relação da canção de Siruiz com o "destino individual”, o percurso iniciático e o processo de aprendizagem de Riobaldo.

Dialogando com clássicos da tradição literária - como Vita Nuova, de Dante Alighieri, Os anos de aprendizado de Wilhelm Meister, de Goethe, e a obra inacabada Heinrich von Ofterdingen, de Novalis, que também apresentam heróis a terem seus destinos e suas aprendizagens pressentidos e preditos por enigmáticos cantos e versos que, inicialmente obscuros, cifrados, culminariam, ao final do percurso narrativo, em um instrumento de decifração e de elucidação de suas travessias -, a canção ouvida da voz de Siruiz por um Riobaldo ainda menino, numa orvalhada madrugada lírica e épica de maio, primeiro encontro com a canção, primeiro encontro com a jagunçagem, é muito mais do que uma simples balada boiadeira.

Apoiando nossa pesquisa não apenas na interpretação da hermética glosa oferecida pelo próprio Rosa no meio do romance, mas também mergulhando na importância dos nomes, da mitopoiesis e da geografia mítico-sertaneja em Rosa - em que, segundo Candido, em "O homem dos avessos" ", homem e paisagem são mesclas da realidade e símbolos -, numa perspectiva hermenêutica, indo do grande para o pequeno e do pequeno para o grande, pretendemos ir além na decifração, atendo-nos, inclusive, aos versos que o próprio Riobaldo fez para dar sequência à canção de Siruiz, quando ela parecia querer já desaparecer de sua memória

${ }^{1}$ Grande sertão: veredas. $19^{\mathrm{a}}$ ed. Rio de Janeiro: Nova Fronteira, 2001, p. 170. Todas as citações de páginas do GSV tomarão por referência essa edição.

${ }^{2}$ ARRIGUCCI Jr., Davi. “O mundo misturado: romance e experiência em Guimarães Rosa”, in: Revistas Novos Estudos CEBRAP (40). São Paulo, outubro, 1994, p. 7-29.

${ }^{3}$ Levantado por SPERBER, Suzi. Frankl, in: Caos e cosmos - Leituras de Guimarães Rosa. São Paulo: Livraria Duas Cidades, 1976.

${ }^{4}$ CANDIDO, Antonio: "O homem dos avessos". In: COUTINHO, Eduardo F. (org.) Coleção fortuna Crítica: Guimarães Rosa. Rio de Janeiro: Civilização Brasileira, 1991, p. 294-320. 
ou, feito o domar do cavalo Siruiz, quando ele já começava a tomar, pelas próprias mãos, as rédeas de um destino supostamente fáustico e predito pela canção, mas que, todavia, pedia transformações.

Para a análise das mutações sofridas por Riobaldo e do caminho de ascese, de elevação espiritual - ou de "aventuras épico-metafísicas", como afirma Francis Utéza - e de aprendizagem pelo narrador vivenciados em Grande sertão: veredas, buscamos aproximar a obra de Rosa à de outros ícones da literatura mundial.

Para tratar do motivo fáustico, nossa análise comparada teve como lastro principal o enfoque do pacto demoníaco e de sua representação a partir de Johann Wolfgang von Goethe, no seu Fausto (1808 e 1832). Como afirma Marks: “A tradição fáustica, do pacto com o demônio, é recorrente na literatura ocidental (...) Proeminentes autores debruçaram-se sobre o tema, que traz em sua essência a relação do ser humano com essa esfera supra-humana, que está fora do alcance do indivíduo e faz parte do universo das divindades, mas que, em determinadas circunstâncias, surge e estabelece contato com a realidade. ${ }^{5}$ E Rosa, mesmo com as singularidades de seu romance e de sua inventiva escritura, mesmo com as incertezas de Riobaldo sobre a veracidade do pacto e sobre a própria existência do diabo, não procedeu diferente. Analisar o suposto pacto fáustico do narrador de Grande sertão: veredas, em perspectiva comparada com a tradição fáustica, é fundamental para esclarecer os versos por ele compostos, seus contextos, e as relações deles com a canção de Siruiz e a narrativa como um todo.

Para abordar o arquetípico poder de revelação da canção de Siruiz e o suposto percurso iniciático de Riobaldo - outras esferas supra-humanas do romance, outras tentativas de se estabelecer relações com o metafísico -, analisamos a obra-prima rosiana também em perspectiva comparada com outros clássicos da tradição literária ocidental, em particular, com a Teogonia, de Hesíodo e A Divina Comédia, de Dante Alighieri. Além disso, não perderemos de vista os diálogos mantidos por Rosa com a Bíblia Sagrada, outra importante fonte de inspiração e referência dialógica para o autor e seu romance.

Sabendo-se que, tal e qual o Riobaldo de Grande sertão: veredas, Guimarães Rosa não esperdiça palavras e que nada em sua escritura é "macaquice", dado do acaso, começamos nosso estudo com a análise da importância das canções e da mitopoiesis das "palavras cantadas" na obra rosiana. Se, na Teogonia hesiódica, pelas Musas tudo começou, o começo da exploração dessa outra "teogonia moderna", que é o Grande sertão: veredas, não poderia ser diferente.

A obra de Rosa entoa e ecoa um infinito, um sem fim, de cantos. Das cantigas boiadeiras e da tradição sertaneja colhidas durante as incursões que o autor fez nos gerais mineiros e que, por suas linhas, readaptadas ou ressignificadas, ganham e trazem nova luz às narrativas às quais prefaciam ou intercalam, até os sons dos

\footnotetext{
${ }^{5}$ MARKS, Maria Cecília. Fausto e a representação do Diabo na Literatura: Um estudo comparativo da tradição fáustica em Guimarães Rosa, Thomas Mann e Fiódor Dostoiévski. Tese de Mestrado FFLCH-SP, 2012, p. 11.
} 
pássaros, convertidos em simbólicas e sugestivas onomatopeias, ou os cantos litúrgicos e glossolálicos - por vezes, inclusive, entoados pelo próprio diabo a tocar sua viola -, toda palavra cantada em Guimarães Rosa, tal as filhas de Mnemosine, parecem convocar e convidar os leitores ao desejo de decifrar e de se deixar transportar para tempos outros, primevos tempos, em que o aedo era também, e ao mesmo tempo, poeta, tradutor e adivinho. Poeta, por trazer plumagem, som e cor às palavras a serem cantadas; tradutor daquilo que precisava ser apreendido, cifrado e decifrado, arcaica e arquetípica voz das divindades; e adivinho, profeta, por conjugar presente, passado e futuro num só instante, o tempo da eternidade, tempo das Musas e da música.

Mergulhar nesse universo sonoro e tentar entender o encanto do canto - essa algaravia, essa chirimia, essa glossolalia, essa lírica e, tantas vezes, melancólica e incognoscível mitopoesia -, em Rosa, é acompanhar Orfeu em seus transes e trânsitos pelos labirintos do desconhecido e, como o lírico herói, ser vencido pelo irresistível desejo de olhar para trás. É dançar ao som da viola de Queluz e, em uníssono, entoar os tantas vezes proibidos cânticos em noite de festejo de São Gonçalo do Amaranto. É se deixar seduzir, sem cera nos ouvidos, pelo perigoso canto das sereias. E, nessa "navegação no mar alto" proposta por Candido, como afirma Gabriela Reinaldo ${ }^{6}$, é seguir a lição de Ulisses, da qual aprendemos que nem sempre é preciso se tapar os ouvidos com cera e, amedrontados com os caminhos e descaminhos do encanto, continuar remando. “Amarremo-nos ao mastro - afirma Reinaldo, com quem concordamos - e deixemos que as sereias cantem. Desfrutemos de doces momentos de insanidade. Sem nos precipitarmos no mar."

\footnotetext{
${ }^{6}$ REINALDO, Gabriela, in: Uma cantiga de se fechar os olhos... - Mito e música em Guimarães Rosa. São Paulo: Annablume; FAPESP, 2005, p. 17.
} 


\section{GRANDEZAS CANTÁVEIS}

A lembrança dela me fantasiou, fraseou - só face dum momento - feito grandeza cantável, feito entre madrugar e amanhecer.

(Grande sertão: veredas, Guimarães Rosa $)^{7}$

As sertanejas linhas e trilhas, sons e silêncios, da obra de Guimarães Rosa, entoam e ecoam reverberam - um sem fim de cantos. Há música por toda parte nos sertões rosianos. Uma grandeza cantável $^{8}$, dir-nos-ia o Riobaldo, de Grande sertão: veredas, em face de coisa de tanta importância.

Para além da musicalidade e da sonoridade típicas da natureza e da tradição sertanejas - como o canto dos pássaros, o zumbido dos mosquitos e os sons dos outros bichos, do mato, dos rios e riachos, das cachoeiras, chuvas, ventos e carros de boi, dos aboios e vaquejadas, das cantigas de ninar, das celebrações religiosas e das coplas, repentes e modas dos cantadores e violeiros, sem falar dos hinos de amor e de guerra, dos reisados e lundus, das saudações e ladainhas -, há ainda os cantos e cantigas inventados pelo próprio Rosa e é disso que, de imediato, pretendemos tratar neste itinerário em busca da canção de Siruiz.

Dentre tantas canções que se bifurcam, se ramificam e se entrecruzam feito as águas do São Francisco ou do Urucuia no meio, no além e no aquém de um grande sertão transmutado, pelo princípio do Verbo, em mundo e imensidão, grosso modo, respeitando a lição de Heráclito ${ }^{9}$ - afinal, como afirma Riobaldo, tudo é e ñ̃a é... (GSV, p. 27) -, tentaremos, para início de conversa, vasculhar passo a passo, linha e linha, a obra rosiana a fim de agrupar ou categorizar, por meio de uma organização consciente, essas inventivas canções criadas ou recriadas por Rosa. Para tanto, buscaremos as aparentes afinidades mantidas entre elas, suas riquezas sugestivas, seus contextos, suas fontes comuns de inspiração e as hipotéticas intenções criativas do autor.

\footnotetext{
${ }^{7}$ Grande sertão: veredas. 19a. ed. Rio de Janeiro: Nova Fronteira, 2001, p. 57.

${ }^{8}$ Os termos e trechos transcritos de Grande sertão: veredas estarão grafados em negrito e itálico. As referências das páginas virão precedidas da sigla GSV.

${ }^{9}$ Aqui, vale lembrar a reelaboração que Rosa, na voz de Riobaldo, faz da máxima heraclitiana: Assaz o senhor sabe: a gente quer passar um rio a nado, e passa; mas vai dar na outra banda é num ponto muito mais em baixo, bem diverso do que em primeiro se pensou. Viver não é muito perigoso? (GSV, p. 51). Não pretendemos, neste início de estudo, fechar conceitos ou conter completamente os diversos significados das diversas canções da obra rosiana, afinal elas se "bifurcam", espalhando e espelhando a vasta e labiríntica bagagem cultural e intuitiva do autor, antes, almejamos apontar caminhos de interpretação pertinentes ao roteiro de tentativa de busca e de decifração da canção de Siruiz.
} 
Há, em Guimarães Rosa, por exemplo, tal e qual em tempos arcaicos e anteriores à escrita, cantigas que curam ${ }^{10}$ - como as de Aristeu ${ }^{11}$ para com o adoecer de alma e de corpo de Miguilim, em “Campo Geral"12, "cantiga memoriã", que "de profundo dizia" -, ou cantigas que tentam, de modo catártico, curar - como a que o próprio Miguilim cantava para si na despedida da sua recém-partida Cuca Pingo-de-Ouro ${ }^{13}$, canto fúnebre, saudoso e melancólico canto de consolo e redenção em face da crueldade da realidade regida pelos adultos, cantiga que, acreditava o menino, podia com seus tristes versos de despedida e de saudade, tal como um phármakon platônico ${ }^{14}$, veneno e remédio ao mesmo tempo, fazê-lo se entristecer menos, sentir-se menos saudoso, e esquecer.

E há as cantigas de êxtase, transes e trânsitos, como o dionisíaco canto da filha e da mãe de Sorôco ${ }^{15}$, em Primeiras Estórias. Cantiga que “já não vigorava certa, nem no tom, nem no se-dizer das palavras - o nenhum”, espécie de descante que desautorizava o sentido da letra, jamais conhecida pelo leitor, mas que representava, na voz daqueles que a entoavam, “de outrora grandezas, impossíveis", uma glossolálica ${ }^{16}$ canção de embriaguez e de transcendência. Canto órfico que parecia conduzir aos subterrâneos do mundo para poder trazer de volta, apaziguando feras, seduzindo o próprio senhor das trevas. Cantilena fúnebre de adeus, mas também de libertação. Canção santa, demoníaca - daimônica - canção que "ninguém não entendia" e que, mais por isso, mesmo sem compreensão, no "acorçoo do canto", todos entendiam demais, a

10 TORRANO, Jaa, em "O mundo como função das musas”, in: Teogonia - a origem dos deuses, de Hesíodo. São Paulo: Iluminuras, 2007, ao tratar dos milênios anteriores à adoção e à difusão da escrita e da importância e do poder da poesia oral como "o centro e o eixo da vida espiritual dos povos, da gente que - reunida em torno do poeta numa cerimônia ao mesmo tempo festiva, religiosa e mágica - a ouvia", comenta:

“(...) a palavra cantada tinha o poder de fazer o mundo e o tempo retornarem à sua matriz original e ressurgirem com o vigor, perfeição e opulência de vida com que vieram pela primeira vez. A recitação de cantos cosmogônicos tinha o poder de pôr os doentes que os ouvissem em contato com as fontes originárias da Vida e restabelecer-lhes a saúde, tal o poder e o impacto que a força da palavra tinha sobre seus ouvintes" (p. 19).

${ }^{11}$ Em carta a Edoardo Bizarri, in: João Guimarães Rosa - Correspondências com seu tradutor italiano Edoardo Bizzarri. Rio de Janeiro: Nova Fronteira, 2003, Rosa relaciona Aristeu com Apolo, deus que preside os oráculos gregos, associado à música, à alegria, ao sol. Afirma o autor: "pois, como V. sabe, Aristeu era uma das personificações de Apollo - como músico, protetor das colmeias de abelhas e benfazejo curador de doenças" (p. 39-40). Em "Campo Geral” (ROSA: 2001), vemos que Aristeu, com seu canto, com sua alegria, cura duas vezes Miguilim:

- Escuta, meu Miguilim, você sarou foi assim, sabe: ...Eu vou e vou e vou e volto!/ Porque se eu for/ Porque se eu for/ Porque se eu for/ hei de voltar... (p. 78-79) (...)

Seu Aristeu, quando deu de vir, trazia um favo grande de mel de oropa, enrolado nas folhas verdes. - 'Miguilim, você sara! Sara, que já estão longe as chuvas janeiras e fevereiras... Miguilim, você carece de ficar alegre. Tristeza é agouraria...' [...] Escuta como você vai sarar sempre: Amarro fitas no raio,/formo as estrelas em par,/ faço o inferno fechar porta,/ dou cachaça ao sabiá,/ bota gibão no tatu,/ calça espora em marruá;/ sojigo onça pelas tetas,/ mô de os meninos mamar!

Seo Aristeu fincava o dedo na testa, fazia vênia de rapapé no meio do quarto, trançava as pernas, ele era tão engraçado, tão comprido.

- Adeusinho de adeus, Miguilim. Quando você sarar mais, escuta, é assim: Ô ninho de passarim,/ ovinho de passarinhar:/ se eu não gostar de mim,/ quem é que vai gostar?"(p. 146-147).

${ }^{12}$ ROSA, Guimarães. Corpo de baile - Volume 1. $3^{\mathrm{a}}$ ed. Rio de Janeiro: Nova Fronteira, 2010, p. 13-156.

13 "Minha Cuca, cadê minha Cuca?/ Minha Cuca, cadê minha Cuca?/ Ai, minha Cuca/ que o mato me deu!...", repetia Miguilim a cantiga do Menino Triste, da história que um dia lhe contaram. (ROSA, 1994: 35).

${ }^{14}$ Phármakon é um termo grego de sentido ambíguo, podendo ser traduzido - entre outros significados - como remédio e como veneno. Em Fedro, e depois também em A República, Platão afirma que a linguagem é um phármakon.

15 "Sorôco, sua mãe, sua filha", in: ROSA, Guimarães. Primeiras estórias. Rio de Janeiro: Nova Fronteira, 2005, p. 61-69.

${ }^{16}$ Segundo REINALDO, Gabriela, in: Uma cantiga de se fechar os olhos... - Mito e música em Guimarães Rosa. São Paulo: Annablume; FAPESP, 2005, glossolálica é a "voz da divindade, inacessível aos planos da razão. Linguagem que foge de seu papel fundamental de representação. A glossolalia está ligada à ideia de uma pretensa linguagem universal” (p. 128-129). A glossolalia, do grego glôssais lalein, falar em línguas, é um fenômeno recorrente nos cultos primitivos. 
ponto de cantarem juntos após a partida de filha e mãe, em uníssona comunhão com Sorôco, pai e filho, na hora da volta ao lar, até onde a cantiga os levasse, todavia, contrariando o mito de Orfeu, sem olhar para trás.

Há também as cifradas canções de advertência ou admoestação moral ${ }^{17}$, espécie de sobreavisos aos personagens - e leitores - a respeito das estórias e destinos que, pelas linhas rosianas, compartilham. Em “diálogo"18 com Günter Lorenz (1991: 86), Rosa afirma que, no sertão, “os anjos ou o diabo ainda manuseiam a língua". Em "Sarapalha"19, traindo o pacto de silêncio proposto e aconselhado pelos versos da cantiga de um capiau beira-rio ${ }^{20}$, versos esses que servem de advertência moral e de epígrafe ao conto, o sertanejo Argemiro "canta fora de hora" e confessa ao primo Ribeiro a culpa e o pecado de ter se enamorado de sua esposa.

O destino comum de Argemiro e de Ribeiro, predito e interdito no verso "coitado de quem namora", da canção capiau, feito cifras manuseadas por um Deus, ou por um diabo, concretiza-se, e os primos sertanejos se separam: Argemiro é expulso e liberto da fazenda e da companhia de Ribeiro, que fica apenas acompanhado da negra Ceição, do cachorro Jiló e dos mosquitos da sezão.

Pouco antes, porém, para além da "meiga voz de descante" dos mosquitos, zumbido "soturno e sombrio" de espera da morte, para além da zoeira do quinino subindo à cabeça dos "febrentos", "para

\footnotetext{
${ }^{17}$ SPERBER, Suzi F., in: Caos e Cosmos - Leituras de Guimarães Rosa. São Paulo: Livraria Duas Cidades, 1976, ao analisar a biblioteca de Rosa - que contava, por ocasião de sua morte, com 2477 volumes -, deixa clara a predileção do autor pelas ditas "leituras espirituais", todavia, em nota, faz uma ressalva: "Com esta denominação queremos indicar as obras de caráter religioso e moral, não as filosóficas propriamente ditas, das mais diferentes tendências e níveis.” (p. 17). O próprio autor, pela voz de Riobaldo, confirma a importância dessas leituras em frases que poderiam ser tomadas em sentido autobiográfico: Muita religião, seu moço! Eu cá, não perco ocasião de religião. Aproveito de todas, bebo água de todo rio. (GSV, p. 32); Eu gosto muito de moral. (GSV, p. 31). Um trecho de correspondência entre Rosa e Bizzarri, op. cit., endossa essa aproximação entre autor e obra em GSV: “[...] sou profundamente, essencialmente religioso, ainda que fora do rótulo estricto e das fileiras de qualquer confissão ou seita; antes, talvez, como o Riobaldo, do 'G.S.V', pertença eu a todas. E especulativo demais. Daí, todas as minhas, constantes, preocupações religiosas, metafísicas, embeberem meus livros. Talvez meio-existencialista-cristão (alguns me classificam assim), meio neoplatônico (outros me carimbam disto), e sempre impregnado de hinduísmo (conforme terceiros). Os livros são como eu." (2003: 90). HAZIN, Elizabeth, em sua tese de doutorado "No Nada, o Infinito" (da gênese de "Grande Sertão: Veredas"); São Paulo: USP, 1991 (p. 270 272), ressalta que nessa "moral" assimilada pelo autor e disseminada em sua obra, não há lugar para maniqueísmos, tudo se relativiza, tudo se complementa, inclusive o bem e o mal. Afirma a pesquisadora - citando a "fórmula analógica dos alquimistas e rosa-cruzes tão caros a Guimarães Rosa 'id quod inferius sicut quod superius '”, - que, para Rosa, a ideia de que as coisas são boas ou más depende de cada um, de sua maneira de ser e de encarar o mundo. E, para confirmar essa tese, transcreve trechos de páginas destacadas, pelo próprio autor, da revista $O$ Pensamento e mantidas por ele guardadas - hoje, na pasta E18 do IEB - (os grifos são de Rosa):

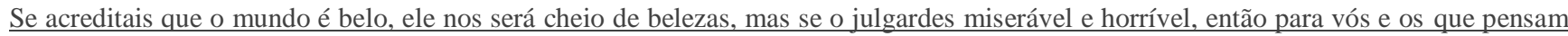
como vós, ele assim é. (E18, p. 33)

O mundo pode ser e é o céu ou o inferno, conforme o fazeis por vós mesmo. Podeis olhar para um tanque e ver o céu refletindo nele; ou podeis ver apenas a sujidade e o barro no fundo. Ambas as vistas são verdadeiras, porém são lados opostos da verdade; pois o mundo é como um espelho, em que todas as coisas são refletidas e o homem pode escolher o aspecto que lhe aprouver. (E18, p. 33)

E a pesquisadora conclui: "Permeando o Grande sertão: veredas, essas ideias vêm à luz também em reflexões orais de Riobaldo: $\boldsymbol{O}$ mal ou $\boldsymbol{o}$ bem, estão é em quem faz, não é no efeito que dão. (GSV, p. 113); "Sertão não é o malino nem caridoso, mano oh mano! - ele tira ou dá, ou agrada ou amarga, ao senhor, conforme o senhor mesmo.” (GSV, p. 537); O que há é uma certa coisa - uma só, diversa para cada um - que Deus está esperando que esse faça. Neste mundo tem maus e bons - todo grau de pessoa. Mas, então, todos são maus. Mas, então, todos não serão bons? (GSV, p. 328)".

${ }^{18}$ Rosa pediu a Lorenz que não tratasse o encontro que mantinham no "Congresso de Escritores Latino-Americanos", em Gênova, janeiro de 1965, como entrevista, e respeitaremos sua vontade, tratando-o, como fez Afrânio Coutinho, como "diálogo".

${ }^{19}$ ROSA, Guimarães. Sagarana. Rio de Janeiro: Nova Fronteira, 2001, p. 151-173.

20 “Canta, canta canarinho, ai, ai, ai.../ Não cantes fora de hora, ai, ai, ai.../ A barra do dia ai vem, ai, ai, ai.../ Coitado de quem namora!... (o trecho mais alegre, da cantiga mais alegre, de um capiau beira-rio)” (ROSA, 2001: 151).
} 
consolar", e da "música santa, de outro mundo" que brota de dentro do corpo dos que têm febre, e para além do pacto de silêncio e da dor em silêncio dos primos, outra canção, de uma outra funesta estória, a pedido de Ribeiro, é evocada pela voz de Argemiro. Trata-se de uma encantatória cantilena entoada por um diabo bonito e encantador - "vestido com roupa de dia-de-domingo e com a viola enfeitada de fitas" -, chamando uma moça para fugir com ele: "Eu vou rodando/ rio-abaixo, Sinhá.../ Eu vou rodando/ rio-abaixo, Sinhá...” (p. 167-168). E, por mais que Argemiro dissesse tratar-se de uma narrativa triste, a sinistra e arcaica história do moço-bonito capeta e de sua canção, feito as vozes das Musas, parecia tranquilizar Ribeiro, fazendo-o melhorar, tornando em remédio o que veneno era e, por isso, o primo abandonado pela esposa insistia em, repetidas vezes, pedi-la, ouvi-la, clamar por ela - pela canção, pela amada ausente.

A vertiginosa canção do diabo belo convidando, rio-abaixo, a mocinha a se perder, aliviava a vertigem da febre e da dor de Ribeiro, que também teve sua amada Luísa seduzida por um forasteiro, que também tinha se perdido por amor: "coitado de quem namora", predizia o "trecho mais alegre, da canção mais alegre, de um capiau beira-rio", as sinas de Argemiro e de Ribeiro.

Há ainda, em Rosa, as cantigas de retorno ao passado, às origens - muitas vezes associadas a um passado arquetípico, uma $\operatorname{arche}^{21}$, um modelo. Cantos que propiciam uma espécie de retorno restaurador no tempo por meio de memórias que não estão atreladas aos fatos e atos do cotidiano, aos eventos corriqueiros, mas que, como em "Um moço muito branco"22, de Primeiras estórias, funcionam - parafraseando Gabriela Reinaldo (2005) - tal e qual uma ponte para o perdido e o esquecido, para o necessário e o imperecível, "saudade inteirada, a salvo do entendimento". Cantilenas que, feito o canto das Musas da Teogonia hesiódica, conjugam passado, presente e futuro num só instante, o tempo da eternidade.

Sem “crer nem increr", o moço em branco tido por todos como aquele que "perdera a completa memória de si, sua pessoa, além do uso da fala” (p. 140), é levado a uma missa onde os cânticos litúrgicos provocam nele essa "saudade inteirada, a salvo do entendimento, e que por tanto se apurava numa maior alegria coração de cão com dono" (p.141). O rapaz que, antes, só tinha a memória de "olhar sempre para cima", apoiado pelo preto José Kakende, em harmonioso contraste, reversibilidade de opostos ${ }^{23}$, aos poucos rememorava seu lugar, sua origem: "Com a primeira luz do sol, o moço se fora, tidas asas.” (p. 144)

\footnotetext{
${ }^{21}$ TORRANO, Jaa (2007), ao tratar a poesia de Hesíodo como canção arcaica, aponta: "devemos levar em conta o sentido historiográfico da palavra arcaica ('Época arcaica'), o sentido que aponta a anterioridade e a antiguidade (uma canção composta quando o pensamento racional começava a pré-figurar-se), e ainda um sentido etimológico, que envolve a ideia de arkhé, de um princípio inaugural, constitutivo e dirigente de toda a experiência da palavra poética” (p. 15). Para os filósofos pré-socráticos, a arché, arkhé ou arqué (origem) seria um princípio que deveria estar presente em todos os momentos da existência de todas as coisas; no início, no desenvolvimento e no fim de tudo. Princípio pelo qual tudo vem a ser.

22 ROSA, Guimarães. Primeiras estórias. Rio de Janeiro: Nova Fronteira, 2005, p. 139-144.

${ }^{23}$ CANDIDO, Antonio, em "O homem dos avessos" - primeira publicação em 1964 (reprod. de Diálogo. São Paulo (8), nov. 1957, sob o título "O sertão e o mundo" - e, após em "Jagunços e mineiros de Cláudio a Guimarães" - primeira publicação em 1970 -, ao tratar das recíprocas relações de poder entre terra e homem no sertão rosiano, conclui que há, em $G S V$, uma espécie de "grande princípio geral da reversibilidade" que
} 
A busca pela unidade original - pela renovação através dos laços que unem o homem ao imperecível por meio da música e da canção, acontece também em outras narrativas rosianas. Em "Cara-de-Bronze"24, de No Urubùquaquá, no Pinhém, do Corpo de Baile, por exemplo, um tal João Fulano, cantador, cognominado Quantidades, "é pago para não conhecer sossego nenhum de ideia: pra estar sempre cantando modas novas, que carece de tirar de-juízo" (p. 673). Quantidades, à procura da nota certa, sempre experimentando, experienciando, canta sobre Grivo, viajante, vaqueiro e poeta contratado pelo fazendeiro Cara-de-Bronze para que buscasse para ele o "quem das coisas".

Cara-de-Bronze é o apelido de Segisberto Saturnino Jéia Velho Filho ${ }^{25}$, proprietário de muitas terras e incontáveis rebanhos bovinos e equinos, chegado jovem a um recôndito lugar, o Urubùquaquá, onde, com o passar dos anos, constrói poder e riqueza.

Também conhecido como Sigisbéu, Sejisbel, Saturnim, Xezisbéo Saturnim, Jizisbéu, Zijisbéu Saturnim, Sezisbério ou simplesmente como o Velho ${ }^{26}$-, Cara-de-Bronze aparece na novela já idoso, adoecido, paralisado, todavia, como afirma Hill (2009), tudo comandando do quarto da casa grande em que se fizera recluso. A alcunha principal pelo personagem recebida vem, de uma primeira impressão, de sua face crestada pelo tempo e pelo sofrimento, e tal epíteto associa-se ao mistério geral da obra, pois nada se sabe sobre quem ou o que a cunhou assim.

dá, à obra, "um caráter fluido e uma misteriosa eficácia". Acreditamos que esse princípio pode ser expandido e aplicado à análise não apenas do romance, mas da obra rosiana como um todo, e, portanto, tomamos essa tese como premissa. Sobre a "misteriosa eficácia" oriunda do "princípio da reversibilidade", afirma Cândido, em "O homem dos avessos":

A ela se prendem as diversas ambiguidades. Ambiguidade da geografia, que desliza para o espaço lendário; ambiguidade dos tipos sociais, que participam da Cavalaria e do banditismo; ambiguidade afetiva, que faz o narrador [de GSV] oscilar, não apenas entre o amor sagrado de Otacília e o amor profano da encantadora 'militriz' Nhorinhá, mas entre a face permitida e a face interdita do amor, simbolizado na suprema ambiguidade mulher-homem que é Diadorim; ambiguidade metafísica, que balança Riobaldo entre Deus e o diabo, entre a realidade e a dúvida do pacto, dando-lhe o caráter de iniciado ao mal para chegar ao bem. Estes diversos planos da ambiguidade compõem um deslizamento entre os polos, uma fusão de contrários, uma dialética extremamente viva - que nos suspende entre o ser e o não ser para sugerir formas mais ricas de integração do ser. E todos se exprimem na ambiguidade inicial e final do estilo, a grande matriz, que é popular e erudito, arcaico e moderno, claro e obscuro, artificial e espontâneo. (p. 134-135)

${ }^{24}$ ROSA, Guimarães. Corpo de baile - Volume 2. $3^{\mathrm{a}}$ ed. Rio de Janeiro: Nova Fronteira, 2010, p. 203-276.

${ }^{25}$ Merecem análise os termos que compõem o nome batismal de Cara-de-Bronze. O Titã Saturno, que dá origem ao seu primeiro sobrenome para a mitologia grega Cronos, filho mais jovem de Urano, o Céu, e de Geia, a Terra - é a representação mítica romana do tempo e do passado incomensurável. Segundo MACHADO (2003), pela idade avançada e pelo domínio territorial, Cara-de-Bronze está sob o patrocínio de Saturno (senhor do Tempo) e de Geia (a Terra) - "O Velho, com a cabeça encalombada de bossas - como se dela fossem brotar idades e montanhas" e o "Filho", do final do nome, representam o núcleo de um problema que poderia inclusive abrir uma linha psicanalítica de análise edípica. HILL, Amariles Guimarães, in: "Cara-de-Bronze", publicado em Navegações - revista eletrônica Pucrs - v. 2, n. 2, p. 91-94, jul./dez. 2009, retoma, para a análise do nome, autores que muito influenciaram a escritura de Corpo de baile, inclusive, o segundo, servindo de epígrafe à obra: “[...] a influência de Saturno é aprofundada em Hesíodo e Jan Ruysbroeck, acentuando os atributos das personalidades saturninas, que seriam a melancolia (melanía, "negrura", em grego), a tendência à meditação e à especulação metafísica, e à apreciação das artes, características encontráveis na apresentação do Cara-de-Bronze". Para aprofundamento das especulações metafísicas, segundo CHEVALIER, Jean \& GHEERBRANT, Alain. Dicionário de Símbolos, $15^{\text {a }}$ ed. Tradução: Vera da Costa e Silva. Rio de Janeiro: José Olympio Editora, 2000, sob uma ótica astrológica, Saturno "encarna o princípio da concentração, da contração, da fixação, da condensação e da inércia. É, em suma, uma força que tende a cristalizar, a fixar na rigidez as coisas existentes, opondo-se, assim, a toda mudança, Saturno é o chumbo do pensamento hermético". (p. 806).

${ }^{26}$ Sobre os diversos apelidos da personagem, afirma HILL (2009): “Constatada a polionomásia como processo habitual do escritor [Guimarães Rosa], essas variantes talvez sejam as mais numerosas aplicadas a uma personagem. A sequência em que aparece o conjunto, organizado na narrativa para orientar (ou desorientar) a busca do nome "verdadeiro", é similar àquela que motiva e estrutura a estória "Famigerado", em Primeiras estórias. 
Cara-de-Bronze, casmurro, ressabiado, paralisado, é o que "quer saber o porquê de tudo nesta vida", "pensa sem falar dias muito inteiros" e "em qualquer lugar que estivesse, era como se tivesse medo de espiar pra trás”, comentam os vaqueiros que com ele convivem e que são seu único canal de comunicação com o mundo.

Envelhecido, "morgado de morte", o fazendeiro que "acredita em mentiras, mesmo sabendo que mentira é", que outrora tanto quis esquecer, "descontente de triste", imobilizado como em bronze por memórias do que supõe ter acontecido, busca com as estórias do poeta Grivo, pelas canções de Quantidades, “o toque de viola sem viola..., coisas iguais ao que nunca em mão se pode ter pertencente...”, busca “alvíssaras de alforria" 27 , pois sabe que, para o áureo Grivo, toda noite é promessa de aurora, e sabe também que sempre pode haver uma "pedra-de-ouro no caminho" e que "todo buriti é uma esperança". E o violeiro da estória canta: "Buriti vendeu seu coco/ tem família a sustentar:/ninho de arara vermelha/ dois ovinhos por chocar..." (p. 690).

Da canção de Quantidades, temos o velho e plúmbeo fazendeiro metaforizado em buriti, alienado de seus frutos, mas temos também os "ovinhos a chocar" e a "brotação das coisas" - o "raminho com orvalhos" da poética voz do Grivo, a “noite p'ra a aurora/ pedra-de ouro no caminho” da sextilha que serve de epígrafe ao conto -, esperança oriunda do platônico ${ }^{28}$ conhecimento pela rememoração.

E, noutro trecho da labiríntica narrativa, da hermética cantiga, João Fulano conclui: "Perguntei: Vaquinha branca,/ teu nascido e teu sinal?/ - Bezerrinho de três ${ }^{29}$ dias/ pasto do Buritizal...“" (p. 713). Pouco antes, Grivo, recém-retornado de viagem, decifrava aos vaqueiros - cavaleiros do Cara-de-Bronze -, os mistérios da vida do dono das terras, desvendados na cruzada que lhe fora demandada pelo patrão, e contava

\footnotetext{
${ }^{27}$ Em carta a Bizzarri (2003: p. 100), Rosa explica: "Literalmente: Alvíssaras = prêmio que se dá a quem anuncia boa nova, notícia boa . Alforria: libertação (de escravo). Como já notou a sextilha [que serve de epígrafe ao conto] se refere à POESIA". Merece nota a sextilha de boas novas comentada por Rosa: Eu sou a noite p'ra a aurora,/ pedra-de-ouro no caminho:/ sei a beleza do sapo,/ a regra do passarinho;/ acho a sisudez. da rosa,/ o brinquedo dos espinhos. (DAS CANTIGAS DE SERÃO DE JOÃO BARANDÃO) (ROSA, 1994: 667).

${ }^{28}$ REINALDO (2005) retoma a importância de Platão, e do Timeu, para a compreensão de Corpo de Baile: "No Timeu, Platão diz que, para formar o belo, o artista tem que ter acesso ao modelo original, ao que não está sujeito ao devir e de onde tudo provém, a brotação das coisas" (p. 69). Do próprio Timeu: "Quando o artista trabalha em sua obra, a vista dirigida para o que sempre se conserva igual a si mesmo, e lhe transmite a forma e a virtude desse modelo, é natural que seja belo o fruto que realiza" (28a-b).

${ }^{29}$ Vemos em CHEVALIER, \& GHEERBRANT (2000: 899): “O três é um número fundamental universalmente. Exprime uma ordem intelectual e espiritual, em Deus, no cosmo ou no homem. Sintetiza a triunidade do ser vivo ou resulta da conjunção do 1 e do 2 , produzido, neste caso, da União do Céu e da Terra." Vale lembrar que, no mesmo dicionário, temos que o 1 representa o princípio criador (p. 918), enquanto o 2 - "cifra de todas as ambivalências e desdobramentos [...] zona de conflito e dualismo sobre o qual repousa toda dialética" - representa a criação (p. 346). HAZIN (1991: 144) - citando um estudo seu intitulado "A terceira travessia" e tratando do GSV assim como poderia estar tratando de "Cara-de-Bronze" - denota: "Acredito que a escolha do número três, que não só preside numerologicamente Grande sertão: veredas, mas toda a obra de Guimarães Rosa, deve-se a razões puramente místicas (...) sendo o Grande sertão: veredas um texto dual, onde se confrontam os opostos - o Bem e o Mal, Deus e o Diabo, o Claro e o Escuro -, a meu ver essa radical dualidade é conciliada, ao nível da narrativa, por Riobaldo, que, como aplicando uma fórmula mágica, recorre ao Três, numa tentativa rudimentarmente religiosa de esconjurar os perigos da Travessia". O três, em "Cara-de-Bronze", assim como os esconjuros de Riobaldo e o "bezerrinho de três dias" de Quantidades, simboliza um suposto "equilíbrio ambivalente", pois aproxima opostos, criador e criatura, céu e terra, passado, presente e futuro numa promessa de porvir, semeando eternidade e tornando em dialético, em "caminho entre ideias", o que outrora era apenas dual, propondo, assim, a realidade como essencialmente contraditória e em permanente transformação: travessia.
} 
do pedido dele por alguém "que lhe abençoasse". Nesse momento, temos notícia, pela voz do cantador, da vaquinha branca que pariu no pasto. Na canção de Quantidades, o nascimento de um "bezerrinho de três dias, pasto do Buritizal...” é o alvo princípio, pasto, provisão e alimento pelo qual tudo vem a ser, é a cândida bênção pedida por Cara-de-Bronze, concedida pelo destino e pela candura terneira da poesia de Grivo.

Vejamos o resumo que o próprio Rosa faz da novela "Cara-de-Bronze” para o seu tradutor Bizzarri:

O "Cara-de-Bronze" era do Maranhão (os campos gerais, paisagem e formação geográfica típica, vão de Minas Gerais até lá, ininterrompidamente). Mocinho, fugira de lá, pensando que tivesse matado o pai, etc. Veio, fixou-se, concentrou-se na ambição e no trabalho, ficou fazendeiro, poderoso e rico. Triste, fechado, exilado, imobilizado pela paralisia (que é a exteriorização de uma como que "paralisia da alma"), parece misterioso, e é; porém, seu coração, na última velhice, estalava. Então, sem se explicar, examinou seus vaqueiros - para ver qual teria mais viva e "apreensora" sensibilidade para captar a poesia das paisagens e lugares. E mandou-o à sua terra, para, depois, poder ouvir, dele, trazidas por ele, por esse especialíssimo intermediário, todas as belezas e poesias de lá. O Cara-de-Bronze, pois, mandou o Grivo... buscar Poesia. Que tal? (BIZZARRI: 2003, p. 93-94)

Grivo é como um cavaleiro em busca do Graal, um Parsifal ou um Galaaz sertanejo ${ }^{30}$, e Cara-de-Bronze é o solitário e ferido senhor do castelo, rei e dono das terras, por elas e nelas adoecido, paralítico de corpo e de alma, exilado de si mesmo e do mundo por acreditar que, num passado incomensurável, tinha matado o próprio pai e, por conta disso, para além disso, por perder seu grande amor tentando fugir de sua sina e, de forma edípica, indo ao encontro dela - amor, aliás, que sempre servira de guia para Grivo ${ }^{31}$.

Feito a mítica serpente Uroborus que abocanha a própria cauda, senhor e cavaleiro, passado e presente, completam-se, promissores de devir e de futuro, todavia é a alquímica canção de Quantidades, de um incerto aiodos $^{32}$ João - nome que se confunde com o de Rosa -, que lhes semeia eternidade, dá-lhes, por meio da palavra cantada, ânimo e encantamento - aliás, canto, encanto e encantamento são termos etimologicamente muito próximos - impedindo a mitológica serpente de, no todo, se autodevorar.

\footnotetext{
${ }^{30}$ NUNES. Benedito, in "A viagem do Grivo", de $O$ dorso do Tigre, São Paulo: Editora 34, 2009, concorda que há inúmeros pontos de contato e de relação entre a novela "Cara-de-Bronze" e os romances medievais da Demanda do Graal - tratada por Nunes como Demanda do Gral todavia, traçando também relações com o Gênese e o Deuteronômio bíblicos, acrescenta:

"Em algumas versões da Demanda do Gral, o objetivo da busca é restaurar a saúde e a juventude do Rei, enfermo e extremamente idoso. Mas o único bem, finalmente alcançado em "Cara-de-Bronze" que o Grivo entrega, na volta, ao mandante do feito, é o relato das coisas vistas e imaginadas durante o percurso: a Viagem transformada em palavras, súmula da atividade poética, que abriu os espaços do sertão e os converteu na profusão do mundo natural e humano [...] A missão do Grivo, objeto da demanda que o velho Cara-de-Bronze ordenou, foi retraçar o surto originário da linguagem, recuperar a potencialidade criadora do Verbo. O que ao fim o exemplar viajante entrega ao velho não é a Noiva real, finalidade da viagem para os vaqueiros comuns, mas a imaginária, feita desses 'nadas aéreos' que as palavras são. [...] Foi esse Gral das palavras da vida, que abrem a imaginação, consolam e humanizam, que o Grivo trouxera. 'Palavras de voz. Palavras muito trazidas. De agora tudo sossegou. Tudo estava em ordem'.” (p. 175-176)

${ }^{31}$ REINALDO (2005) chama a atenção para a migração do viajor Grivo de "Campo Geral" para "O Cara-de-Bronze", ambas as obras de Corpo de Baile. "Ele é o menino das palavras sozinhas, o menino que tem intimidade com a poesia em 'Campo Geral”". (p. 65)

${ }^{32} \mathrm{Na}$ Antiga Grécia, a palavra que definia o poeta como cantor (aiodos) é, cronologicamente, anterior a que o definia como fazedor (poietés).
} 
Animado - ou reanimado, reavivado - por uma canção, temos também o personagem Augusto Matraga, de "A hora e a vez de Augusto Matraga"33, da obra Sagarana.

Passando-se por morto, enquanto se recuperava dum atentado de morte na casa com os pretos samaritanos que lhe ofereceram abrigo, Augusto ouve canções como a que a negra entoava lavando panelas - "As árvores do Mato Bento/ deitam no chão p'ra dormir" (p. 378) - e, deitado e adormecido do mundo como as próprias árvores da cantiga, foge de música: “(...) fugia às léguas de viola ou sanfona, ou de qualquer outra qualidade de música que escuma tristeza no coração” (p. 382-383). Todavia, quando escuta a toada de guerra entoada pelo bando de Joãozinho Bem-Bem - "O terreiro lá de casa/ não se varre com vassoura:/ varre com ponta de sabre,/ bala de metralhadora..." (p. 396) - rememora os tempos de outrora, tempos do famigerado Nhô Augusto Estêves, de mau e mal, e sente saudades da bandoleira vida passada, vida em que tudo se varria com ponta de sabre e bala de metralhadora.

Seis ${ }^{34}$ anos, seis anos e meio após o atentado sofrido, sempre repetindo a fala final dum padre que um dia fora trazido pelos pretos para consolar sua alma - "Cada um tem a sua hora e a sua vez: você há-de ter a sua.” (p. 380) -, numa manhã aberta e animada pelo canto das maritacas, das maracanãs, dos papagaios e dos periquitos, todos com muita pressa, "Nhô Augusto saiu para o terreiro e desconheceu o mundo". "Mas, também, como é que podia haver um de-manhã mesmo bonito, sem as maitacas ${ }^{35}$ ?!...” (p. 400).

E, após prestar atenção na beleza de uma rapariga que passava do outro lado da cerca, o pulsional recém-desperto homem novo, augusto e não mais desasado, pegou a cantar uma cantiga, muito velha, de um capiau exilado: “Eu quero ver a moreninha tabaroa,/ arregaçada, enchendo o pote na lagoa...” (p. 400). Assim é narrada a cena no conto:

Cantou longo tempo. Até que todas as asas saíssem do céu.

- Não passam mais... Ô papagaiada vagabunda! Já devem de estar longe daqui... Longe, onde?

"Como corisca, como ronca a trovoada, no meu sertão, na minha terra abençoada..."

Longe onde?

"Quero ir namorar com as pequenas, com as morenas do Norte de Minas..."

Mas, ali mesmo, no sertão do Norte, Nhô Augusto estava. Longe onde, então?

\footnotetext{
${ }^{33}$ ROSA, Guimarães. Sagarana. Rio de Janeiro: Nova Fronteira, 2005, p. 363-413.

${ }^{34}$ De CHEVALIER \& GHEERBRANT (2000: 809), temos que, simbolicamente, o número seis "marca essencialmente a oposição da criatura ao Criador, em um equilíbrio indefinido [...] número da prova entre o bem e o mal".

${ }^{35}$ Evidencia-se, no conto, a relação quase anagramática entre o nome das maritacas - tratadas pelo narrador, respeitando-se a variação linguística local, como "maitacas" - com o sobrenome do protagonista da história, Matraga, a quem os pássaros reconvocam para a vida guerreira, e com os próprios sons produzidos pelos psitacídeos. Por aliteração, todos remetem aos sons "grulhantes, gralhantes" das "maitacas", das matracas e de tiros, os mesmos tiros, aliás, produzidos pelas "balas de metralhadora" da canção do bando de Bem-Bem. Um trecho, extraído do desfecho do conto, torna ainda mais evidente a relação: "E a casa matraqueou que nem panela de assar pipocas, escurecida à fumaça dos tiros".
} 
Quando ele encostou a enxada e veio andando para a porta da cozinha, ainda não possuía ideia alguma do que ia fazer. Mas, dali a pouco, nada adiantava, para retê-lo, os rougos reunidos de mãe preta Quitéria e do pai preto Serapião.

- Adeus, minha gente, que aqui é que mais não fico, porque a minha vez vai chegar, e eu tenho que estar por ela em outras partes!" (p. 400-401)

O mesmo canto que convoca Augusto para a guerra, epifânico, como que regido pelo "princípio da reversibilidade" proposto por Candido, conclama-lhe para a redenção. Montado num jumento, "animal assim meio sagrado, muito misturado às passagens da vida de Jesus” (p. 401), como lhe recordou mãe Quitéria assim como poderia estar montado na jumenta de Balaão do Velho Testamento -, o predestinado cavaleiro Matraga, "sem obrigação nenhuma e bem com Deus", reinterpretando, com suas palavras, a cantiga que ouvira do bando de Joãozinho Bem-Bem - "A roupa lá de casa/ não se lava com sabão:/ lava com ponta de sabre e com bala de canhão...” (p. 401) - é guiado pelo "bendito animal” até o arraial do Rala-Coco, todo ele feito refém da jagunçagem de Bem-Bem. Aí aconteceria a tão esperada hora e vez de Augusto Matraga.

Despertado pela algaravia dos pássaros, intimado pelo canto, selando seu destino de armas, luta e morte, o augusto guerreiro, reverenciado em todo o arraial, redime-se e, retomando o velho provérbio que diz que "roupa suja se lava em casa", livremente parafraseado em sua canção, lava o seu nome, sua alma e sua honra, enfrentando, sozinho, o bando de jagunços e o próprio Joãozinho Bem-Bem para salvar o acossado povoado do arraial:

"Foi Deus que mandou esse homem no jumento, por mor de salvar as famílias da gente!..." E a turba começou a querer desfeitar o cadáver de seu Joãozinho Bem-Bem, todos cantando uma cantiga que qualquer-um estava inventando na horinha:

Não me mata, não me mata

seu Joãozinho-Bem-Bem!

Você não presta mais pra nada,

seu Joãozinho Bem-Bem! (p. 412)

“Eu vou p'ra o céu e vou mesmo por bem ou por mal!... E a minha vez há de chegar... Pr’a o céu eu vou, nem que seja a porrete!...” (p. 381), sentenciara Matraga sua sina ao buscar a salvação de sua alma. A oportunidade, a "hora e a vez" de Nhô Augusto, consiste em fazer do mal, com o mal, o bem, e com isso assegurar, por meio da pulsional violência destruidora do jagunço matador, que ele reprimira até então, a paz do povoado e a redenção de seu espírito. Como bem afirmou Candido, em "Jagunços e mineiros de Cláudio a Guimarães": "O tiroteio e o duelo a faca, com o qual mata Joãozinho Bem-Bem e é por ele morto (como em Grande sertão o Hermógenes e Diadorim), surge [para Matraga] ao modo de um prêmio de Deus".

“É para esses casos 'sem comparação' que se canta. Casos de "não sair da memória", afirma a pesquisadora da musicalidade em Rosa, Gabriela Reinaldo, fazendo uso de trechos de "Sorôco, sua mãe, sua filha" para ilustrar sua proposição. E acrescenta: 
A função do canto, na obra de Guimarães Rosa, parece ser a de tentar de alguma forma nomear o que não pode ser tocado, dito, exposto. É imprimir um signo, assinalar, para que esses fatos não sejam engolidos pela camada dura do real, que embrutece, apaga o que escapa ao mundo dos sentidos, da urgência, da sobrevivência. A música, essa 'imagem rendada', pode aparecer como metáfora para falar do que transcende. O olhar dos amantes para a não distância é como um canto de passarinhos. O canto diz o que não está sujeito às circunstâncias, às mudanças. (REINALDO, 2005: 106)

Na Teogonia, o mundo começa pelo canto: "Pelas musas comecemos..." 36 , diz - ou canta - Hesíodo. ${ }^{37}$ Para tratar da volta ao passado, às origens, e, sob a égide das Musas, por meio do encantamento mitopoético das canções, reorganizar o presente ou, na orvalhada voz de Grivo, de "Cara-de-Bronze", "relembrar alegrias inventadas" - alegrias essas, tantas vezes rebrotadas da tristeza, da dor, da violência, "iniciação ao mal para chegar ao bem" como denotou Candido -, poderíamos ainda citar outras tantas narrativas rosianas, todavia, para não perder de vista os caminhos e descaminhos que nos levam até a canção de Siruiz e suas peculiaridades, nos deteremos, por fim, em "O recado do morro" 38 .

Nessa novela de Corpo de baile, a cantiga de Laudelim Pulgapé - canal de tradução, de transcriação ${ }^{39}$, dos glossolálicos recados que o Morro da Garça ${ }^{40}$ mandava a Pedro Orósio através dos loucos e de outros seres não reflexivos da região, "marginais da razão" - possibilita ao pétreo herói da estória, a são e salvo, após um duelo de morte - como o de Matraga com Joãozinho Bem-Bem ou o de Diadorim com o Hermógenes -, um etéreo e redivivo - elevado - retorno à sua "terra natural": "Mediu o mundo. Por tantas serras, pulando de estrela em estrela, até aos seus gerais" (p. 666).

Todos sabemos da importância que Guimarães Rosa dá à memória ${ }^{41}$, termo que, etimologicamente, descende de Mnemósyne, mãe grega das Musas, deusa que preserva do esquecimento, que devolve e recria

${ }^{36}$ HESÍODO, in: Teogonia - A origem dos deuses. Trad. Jaa Torrano. São Paulo: Iluminuras, 2009, p. 103.

37 TORRANO, Jaa (2009) explica:

A primeira palavra que se pronuncia neste canto sobre o nascimento dos Deuses e do mundo é Musas, no genitivo plural. Por que esta palavra e não outra? Dentro da perspectiva da experiência arcaica da linguagem, por outra palavra qualquer o canto não poderia começar, não poderia se fazer canto, ter a força de trazer consigo os seres e os âmbitos em que são. É preciso que primeiro o nome das Musas se pronuncie e as Musas se apresentem como a numinosa força que são das palavras cantadas, para que o canto se dê em seu encanto (...). $\mathrm{O}$ nome das Musas é o próprio ser das Musas, porque as Musas se pronunciam quando o nome delas se apresenta em seu ser, porque quando as Musas se apresentam em seu ser, o ser-nome delas se pronuncia" (p. 21).

${ }^{38}$ ROSA, Guimarães. Guimarães Rosa - Ficção Completa - Volume I. Rio de janeiro: Editora Nova Aguilar, 1994, p. 615-666.

${ }^{39}$ Termo criado por Haroldo de Campos para atribuir estatuto de criação/configuração a uma tradução poética de uma língua estrangeira para a nacional.

${ }^{40}$ Como epígrafe para o conto, Rosa nos apresenta uma pequena quadra de canção: “- Morro alto, morro grande,/ me conta o teu padecer,/ Pra baixo de mim, não olho;/ p'ra cima, não posso ver... (CONTRACANÇÃO. Peça pseudofolclória)” (ROSA, 1994: 615).

${ }^{41}$ Dialogando com Candido, PRADO JR., Bento, no artigo "O destino decifrado - Linguagem e existência em Guimarães Rosa”, in Alguns Ensaios. São Paulo: Editora Max Limonad, 1985, trata da convergência entre memória e inconsciente, em Rosa:

Antonio Candido já assinalou a importância da memória na obra de Guimarães Rosa, apontando aquele momento em que "o homem do Sertão se retira na memória e tenta laboriosamente reconstruir a sabedoria sobre a experiência vivida, porfiando, num esforço comovedor, em descobrir a lógica das coisas" (in "Diálogos", $\mathrm{n}^{\mathrm{o}}$ 8, p. 18). A meditação sobre o sentido da existência é, assim, essencialmente retrospectiva e nela se superpõem as duas questões essenciais: o que é o que é? o que é o que aconteceu? A descoberta da resposta, ou a decifração do enigma, aparece como catarse e reminiscência, como reconciliação com um si mesmo que se perdera na inconsciência: a 
os sentidos, o ethos, por meio da mediação das palavras pelo poeta. ${ }^{42}$ Aludindo Bento Prado Jr. (1985), rememorar a existência é recapitular um texto há muito conhecido, mas cujas peças fundamentais escapam à consciência. Contudo é duma outra relação com o tempo, com o fluir das águas dos tempos, que também está presente em "O recado do morro" e em sua música, que vamos tratar agora.

Se Mnemosine, em face dos perigos do esquecimento - que na cosmogonia grega aparece como um rio, o Lete (de Lethe ou Lesmosyne, a deusa do esquecimento), rio eterno a cruzar os subterrâneos da morada dos mortos ${ }^{43}$, do "letal" esquecimento - deu à luz as Musas, para, através da música ${ }^{44}$, iluminar-nos, redimirnos, fazer-nos lembrar e sermos lembrados, salvando-nos da mais temida das mortes que é o esquecimento, na Teogonia, Hesíodo afirma também que, quando as Musas querem, “sabem dar a ouvir revelações” (v. 27 28). Assim dizem os versos do poeta grego: "Pastores agrestes, vis infâmias e ventres só,/ sabemos muitas mentiras dizer símeis aos fatos/ e sabemos, se queremos, dar a ouvir revelações” (HESÍODO, 2007: 103).

Jaa Torrano, estudioso e tradutor da teogonia hesiódica, explica os sentidos do termo "revelações" desses versos:

Como desocultação é que os gregos antigos tiveram a experiência fundamental da Verdade. A palavra grega alétheia, que a nomeia, indica-a como não esquecimento, no sentido em que eles experimentaram o Esquecimento não como um fato psicológico, mas como uma força numinosa de ocultação, de encobrimento. Desde as reflexões de Martin Heidegger estamos afeitos a traduzir alétheia por re-velação (como fiz no v. 28), des-ocultação, ou ainda, nãoesquecimento. Isto porque a experiência que originariamente os gregos tiveram da Verdade é radicalmente distinta e diversa da noção comum hodierna que esta nossa palavra verdade veicula. (TORRANO, 2007: 25)

E, ainda tratando da complexidade dos versos da Teogonia, em análise, e das revelações, em particular, Torrano, à luz de Hesíodo, interpreta-os:

As mentiras símeis aos fatos opõem-se às revelações - como a força da simulação ocultadora se opõe à da presença manifesta - e são, no entanto, uma só e mesma força. Para bem compreendermos o sentido dos versos 27-28, em que as Musas indicam que saber constituem, devemos evitar a mera contraposição de verdade e mentira e ainda mais evitar entender verdade e mentira como adequação (ou não) do intelecto à coisa ou como a confirmação (ou não) que a palavra empírica traz ao que a palavra afirma. As revelações que as Musas, se querem, sabem dar a ouvir são des-velações, o retirar-se seres e fatos do reino noturno (i.e., me-ôntico) do Esquecimento e fundá-los como manifestação e Presença. O que passa

solução da trama se encontra no momento em que o herói consegue finalmente ouvir o discurso do Outro com o qual perdera todo contato no mais profundo de sua identidade. (p. 201)

${ }^{42}$ Merece nota um trecho retirado de "Nenhum, nenhuma" ${ }^{42}$, de Primeiras Estórias: "Reperdida a remembrança, a representação de tudo se desordena: é uma ponte, uma ponte - mas que, a certa hora, se acabou, parece'que. Luta-se com a memória." (ROSA, 2005: 99)

${ }^{43}$ Vale lembrar que mesmo no Hades, morada dos mortos, havia uma fonte de Mnemosine, por isso a deusa está associada às nascentes e fontes e, também por isso, as Musas estão sempre relacionadas às ninfas e outras divindades das águas.

${ }^{44}$ Ver etimologia comum do termo música com as Musas e os museus (templos das Musas, templos da memória). 
despercebido, o que está oculto, o não-presente, é o que resvalou já no reino do Esquecimento e do Não-Ser. O que se mostra à luz, o que brilha ao ser nomeado, o não-ausente, é o que Memória recolhe na força da belíssima voz que são as Musas. No entanto, Memória gerou as Musas também como esquecimento ('para oblívio dos males e pausa de aflições', v. 55) e, força numinosa que são, as Musas tornam o ser-nome presente ou impõem-lhe a ausência, manifestam o ser-mesmo como lúcida presença ou o encobrem com o véu da similitude, presentificam os Deuses configuradores da Vida e nomeiam a Noite negra. O próprio ser das Musas geradas e nascidas da Memória as constitui como força de esquecimento e de memória, com o poder entre presença e ausência, entre a luz da nomeação e a noite do oblívio. (TORRANO, 2007: 25-26)

Portanto, para além da preservação do passado e do que não deve ser esquecido, perdido, fonte do conhecimento e da vida, des-velados, e para além do que deve ser esquecido e deixado para trás para a cura dos males e a pausa nas aflições, interessam-nos as revelações das Musas e o controle que têm sobre o passado, o presente e o futuro ${ }^{45}$. Interessa-nos o papel de "legislador das Musas" que Platão atribuiu ao poeta, ao poietés (fazedor), antes tratado como aiedos (cantor). Interessa-nos o poeta, o cantor, o aedo (poeta-cantor) que, através das palavras cantadas pelas Musas, torna-se vidente, profeta, adivinho. E interessa-nos a poesia, a canção, como espécie de possessão pelas Musas, de delírio divino que possui o poeta, o cantor, e o transforma no intérprete de Mnemosine, daquela que tudo sabe.

Por fim, interessa-nos o conhecimento como forma de adivinhação, de profecia, de intuitiva decifração, e os versos e as cantigas da obra de Rosa que, como os oráculos gregos, todavia sem a aparente necessidade de consulta aos deuses, veiculam presságios, profetizam, como faz Laudelim com a canção da novela "O recado do morro", de Corpo de Baile, como acontece com a canção de Siruiz, em Grande sertão: veredas, e como os versos que o próprio Riobaldo, homem de armas e de letras, faz e canta, quando já está quase a se esquecer das quadras originais da canção boiadeira, para tentar, montado no seu cavalo Siruiz, conduzir, com as próprias mãos, as rédeas de seu destino, intervindo e atuando sobre ele. Um destino, aliás, que pede transformações.

Se muitas narrativas rosianas apontam para o que Bento Prado Jr. (1985: 212) tratou, ao analisar a novela "Dão-Lalalão (O Devente)" 46 , como "a existência de um discurso secreto como raiz e solo da memória e da consciência", "O recado do morro" - assim, como acreditamos ser o Grande sertão: veredas, no tocante

45 TORRANO (2007) explica o dom da profecia proporcionado pelas Musas aos aiedos:

Para a percepção mítica e arcaica, o que na presença se dá como presente opõe-se, a uma, ao passado e ao futuro, os quais, enquanto ausência, estão igualmente excluídos da presença. Assim, passado e futuro, equivalentes na indiferença da exclusão, pertencem do mesmo modo ao reino noturno do Esquecimento até que a Memória de lá os recolha e faça-os presentes pelas vozes das Musas. O poeta, portanto, pelo mesmo dom das Musas, é o profeta dos fatos passados e de fatos futuros." (p. 27)

${ }^{46}$ ROSA, João Guimarães, in: Corpo de Baile - V. 2. Rio de Janeiro: Nova Fronteira, 2010, p. 99-201. 
à canção de Siruiz -, ainda fazendo alusão às palavras do estudioso, é bem mais radical, pois visa esse discurso num domínio que precede toda psicologia. Nas palavras de Prado Jr.:

Não mais se trata, aqui, de descobrir aquela fala mais profunda que ata e constitui a identidade pessoal, mas de revelar uma Escritura que se esboça no ponto zero da humanidade e da cultura, na própria Natureza. De uma narrativa a outra, passamos de um a outro nível do Logos; do Logos privado da psiquê ao Logos anônimo e universal do Mito. Em O Recado do Morro, o texto que figura o destino do herói é também o discurso do Outro; mas de um Outro mais radical, exterior e anterior à própria humanidade, domínio onde ainda não se dissociaram logos e fisis; quem fala é o Morro. (1985: 212)

Em "O recado do morro"47, Guimarães Rosa nos dá, pela voz do cantador e aedo Laudelim, uma "mãozinha" na decifração dos herméticos e imprecisos, desatinados recados sobre um rei, uma festa, um destino e uma morte à traição, recados esses “que nem eram do mundo entendível”, que o Morro da Garça, o mais alto da região, manda a Pedro Orósio, protagonista e herói da estória.

Após esses recados serem ouvidos e repetidos ou reapresentados e representados das formas mais esdrúxulas e incognoscíveis possíveis por um velhote grimo de nome Malaquias, mais conhecido como o Gorgulho; por um sujeito sambanga de nome Zaquias, ou Zacarias, ou Catraz - o que "cá traz", cognominado de o Qualhacôco, qualhando ${ }^{48}$ e coagulando coisas dispersas e tentando trazer ao "côco", à razão, o que até então não se entendia -, irmão de Malaquias ${ }^{49}$; por um menino serelepe de nome Joãozezim; pelo bobo Guégue; pelo desvairado beato Nominedômine ${ }^{50}$ e por outro "que não regulava bem" conhecido como o Coletor, a misteriosa mensagem, desprezada por Pedro Orósio durante toda a estória, é transformada transmutada - em apolínea canção por Laudelim.

Em face dos encifrados algarismos e das declarações alucinadas do Coletor, sexto dos emissários do Morro, o órfico Laudelim, sétimo ${ }^{51}$ na cadeia de recadeiros até Pedro Orósio, parecia ter descido aos infernos

47 WISNIK, José Miguel, in "Recado da Viagem", in: Scripta - Revista de Pós-Graduação em Letras e do Cespuc - Edição Especial do Seminário Internacional Guimarães Rosa; v. 1, n 1. Belo Horizonte: PUC Minas, 1997, p. 161, fazendo alusão às correspondências entre Rosa e Bizarri, ao tratar de "O recado do Morro", denota: "Pode-se ler nessa novela uma poética: ela desvela a formação de uma canção, constituindose numa das 'parábases' do Corpo de Baile que, junto com 'Uma estória de amor' e 'Cara-de-Bronze', assinalam a canção, a estória oral e a poesia como três componentes inseparáveis da dimensão épico-lírica da prosa rosiana."

${ }^{48}$ Qualhar é a forma antiga de escrita da palavra coalhar, sinonímica de coagular, termo muito importante para os estudos alquímicos de Guimarães Rosa, como veremos na sequência deste estudo.

${ }^{49}$ Malaquias, etimologicamente "mensageiros de Deus", junto com Zacarias, cujo nome significa "o Senhor se lembra", são os dois últimos profetas do Velho Testamento bíblico. Junto com Ageu, eles encorajaram o povo judeu pós-exílio babilônico decretado por Nabucodonosor II por meio de visões, de profecias e até mesmo de duras repreensões - a voltar e restaurar Jerusalém, o Templo e o viver adequado diante de Deus, repatriação essa permitida pelo imperador Ciro, no começo do século VI a. C. Nota-se que, como em "O recado do morro", trata-se de uma viagem de volta para casa e de restauração de algo perdido e que requer, além de ser (re)encontrado, ser consagrado.

50 MACHADO (2003: 102) chama atenção para a designação do "louco beato Nominedômine", afirmando: "(...) do nome do Senhor tem a revelação de que tudo está é no Nome do Homem, Nomindome."

${ }^{51}$ CHEVALIER \& GHEERBRANT (2000) apontam que, enquanto o seis, para a tradição mítico-religiosa, representa o número da prova, entre o bem e o mal, número mediador entre o Princípio e a manifestação, o sete representa um ciclo concluído, a totalidade do universo em movimento, um pacto entre Deus e os homens. (p. 809-810 e 826-831) 
para, após, retornar à luz e, feito pássaro, em ave-palavra, poder cantar: "enquanto estava ouvindo, seu rosto se ensombreceu, logo se alumiou mais... Ave, matutava.” (p. 654).

O violeiro ${ }^{52}$ entra em transe - ou em estado de graça ${ }^{53}$ - e, mesmo quando Pedro Orósio tenta carregálo pelo braço, ele entrepara: "Isso é importante!”.

"Laudelim era mesmo assim...", afirma o narrador de "O recado do morro", tratando dos trejeitos cismados, "levianamente tristonhos", de uma "tristeza sem razão certa", do violeiro: "dava de com os olhos não ver, com os ouvidos não escutar, e se despreparava todo, nuvejava.” (p. 654).

Quando encontrou Pedro Orósio, Laudelim estava indo em direção ao cemitério, "carecia de visão assim, porque aquela noite tencionava cantar melhores". Agora, após o encontro com o Coletor e seu recado, entusiasmado, mudara de ideia: "Vou mais no cemitério, não. Já achei. [...] Relou as cordas, ponteando, silassimol cantava. Arrastou um rasgadados [...] 'O Rei menino... Passagens fortes...'. - Laudelim deu resposta." (p. 654-655).

“Legislador das Musas”, Laudelim ${ }^{54}$ Pulgapé deu mesmo a resposta. Advertiu, com sua canção, com sua palavra cantada e presentificada - ser, presença e voz das Musas -, Pedro Orósio sobre uma arquitetada trama de morte destinada a ele. Pedro, reconhecendo-se "rei”, lembrando-se do "rei” que é, ao rememorar a canção ouvida da voz de Laudelim, "imagem rendada", e ao dar ouvidos ao recado do morro, parece ter conseguido intervir no destino e se salvar, ser salvo, da traição e, consequentemente, da morte à traição que o futuro lhe reservava. Mas será que é esta, apenas, a única leitura possível do final da novela?

José Miguel Wisnik, em seu "O recado da viagem”, assinalando o "caráter mercurial” de "O recado do morro", endossa o quanto as ambiguidades, dualidades e o arrebatador "princípio da reversibilidade" proposto por Candido estão presentes na estória como um todo e chama a nossa atenção para as ambivalências do desfecho de "O recado do morro":

A canção de Laudelim é a narrativa de uma luta de morte terrível e sanguinária, em que os contendores se entrematam, no limite das forças, rebebendo o próprio sangue. É a sua formulação pela canção, no entanto, que permite a Pedro Orósio, numa intuição que envolve

\footnotetext{
52 ARROYO, Leonardo, in A Cultura Popular em Grande sertão: veredas (1984), denota o papel dos violeiros nas comunidades dos interiores do Brasil: "todos os acontecimentos ocorridos na comunidade constituem objetos de modas de violas, são narrados, ridicularizados, censurados ou lastimados [pelos violeiros]" (p. 55). Além disso, o pesquisador enfatiza as crenças populares que veem ligação das violas e violeiros ora com o sagrado - por exemplo, com a devoção a São Gonçalo, o santo violeiro - ora com o profano - a crença da viola como instrumento do Diabo e dos violeiros como pactários - (pág. 206-207), ressaltando o poder místico atribuído, nesses lugares, a esses músicos e seus instrumentos. Adiante, ao tratarmos do estudo de Grande sertão: veredas - e da canção de Siruiz -, retomaremos o assunto de maneira mais aprofundada.

${ }^{53} \mathrm{O}$ termo garça, do nome do morro que manda o recado a Pedro Orósio, de forma anagramática pode ser lido também como graça.

${ }^{54}$ MACHADO (2003: 104) traz luz ao nome Laudelim:

"Com as campainhas do Nome de Laudelim acompanhando as loas e louvações aí presentes etimologicamente (desde o latim laudare), cumpre-se um ciclo. Pela fé, pela loucura, pela inocência, pela infância, pela poesia, em uma sucessão de videntes privilegiados porque carentes, o recado atinge enfim sua forma estruturada e definitiva, a forma com que irá chegar a seu destinatário, cumprindo sua ascensão desde as profundas grutas dos urubus (os temas em -u- se repetem do início ao fim, em Nomes como Gorgulho e Pulgo, ambos, aliás, designando também como os recônditos insetos daninhos) até as largas passadas para as estrelas com que termina a narrativa, opondo aos timbres escuros dos urubus a claridade e a abertura em -a- do Morro, da Graça."
} 
todos os níveis perceptivos acumulados, antecipar-se à emboscada, salvar-se da morte e, mestre do tempo, depor seu antagonismo saturnino, Ivo Crônico, feito "menino dentro do chão". [...]

A novela assinala o lugar da luta-de-morte, mas, aqui, como se ela prefigurasse ambivalentemente a sua superação, ao mesmo tempo que seu retorno implacável. No caduceu de Hermes, as serpentes, banhadas em sangue como os lutadores da canção de Laudelim Pulgapé, matam-se mutualmente afogando-se no seu próprio veneno. Mas o mesmo bastão alquímico em que elas se enroscam, tomando-as, amansa-as e ganha o poder de "ligar" e de "desligar", de solver e coagular, como nessa viagem do recado, rastreada pelo avesso desde o S onde "começa grande frase". (Burckhardt, 1991, p. 132-137) Interrogação e enigma permanecem. (WISNIK: 1997, p. 169).

Relembremos o desfecho dado por Guimarães a "O recado do morro": “[...] [Pedro Orósio] mesmo com a noite, abriu grandes pernas. Mediu o mundo. Por tantas serras, pulando de estrela em estrela, até aos seus gerais.” (p. 666). Para Machado, em seu “O recado dos nomes”, a interrogação e o hermético enigma do final da novela, apontados por Wisnik, também se sobressaem:

Com as largas passadas de Pedro Orósio ${ }^{55}$, lá vai a Terra abrir-se pelos espaços infinitos. Ao mesmo tempo, saindo do signo do Touro, uma nova constelação persegue as sete estrelas das Plêiades, exatamente como Órion, antepassado de Orósio, como ele pastor, passou para o céu pela força do amor a ousar desafiar o destino dos deuses. (MACHADO: 2003, p. 118)

Se não temos a certeza do desfecho da estória de "O recado do morro", se não sabemos, de fato, o destino final de Pedro Orósio - etimologicamente o pétreo e áureo herói escolhido e protegido das montanhas -, sabemos que o canto de Laudelim e a "canção a formar-se" de toda a narrativa pressupõem um sentido profético, premonitório, sentido de revelação esse, aliás, atestado por Rosa em carta de 25 de novembro de 1963 ao seu tradutor italiano Edoardo Bizzarri:

“'O Recado do Morro' é a estória de uma canção a formar-se. Uma revelação captada não pelo interessado e destinatário, mas por marginais da razão, e veiculada por outros seres não reflexivos, não escravos ainda do intelecto: um menino, dois fracos da mente, dois alucinados - e, enfim, por um artista; que, na síntese artística, plasma-a em canção, do mesmo modo perfazendo, plena, a revelação inicial." 56 (BIZZARRI, 2003: 92)

\footnotetext{
${ }^{55}$ MACHADO (2003: 114-115) analisa o nome de Pedro Orósio:
}

A quem o morro poderia falar, se não àquele que é seu homólogo, que é pedra, montanha, terra? A quem é Pedro como pedra, Orósio como soma de oros ("montanha") e ósio ("escolhido") [...] E Pedro é Pedrão Chãbergo. Pedrão que é a grande pedra ou montanha. Chã que é chão, que é planície e que é simplicidade; ou é carne de boi de talho, mas carne de perna, que o liga ao chão, ao solo, à terra. Bergo que é Berger, do francês, pastor, vaqueiro; mas que também guarda em si Berg, do alemão, pedra mais uma vez. Chãbergo que evoca chamego e lembra as atividades amorosas de Pedro, responsáveis pela rivalidade com os outros e, em última análise, motivo direto da traição."

${ }^{56} \mathrm{Na}$ carta a Bizarri, Rosa despreza, se esquece de - ou deixa passar despercebido - um dos recadeiros do Morro. Em verdade, como já fora ressaltado neste estudo, são seis os recadeiros - Gorgulho, Joãozezim, Catraz, Guegue, Nominedômine e o Coletor - até o violeiro Laudelim. 
Note-se, aí, a importância que Rosa dá ao intuitivo, ao não reflexivo, ao misterioso, hermético e enigmático, ao que escapa da racionalidade e da intelectualidade, ao que antecede a psicologia, "domínio onde ainda não se dissociaram logos e fisis", na tentativa de fugir da megera cartesiana e do tempo profano em busca do tempo da eternidade, do numinoso, do religioso e do metafísico ${ }^{57}$, como atesta o próprio autor em outro trecho da carta a Bizzari:

“Ora. Você já notou, decerto, que, como eu, os meus livros, em essência, são 'antiintelectuais' - defendem o altíssimo primado da intuição, da revelação, da inspiração, sobre o bruxulear presunçoso da inteligência reflexiva, da razão, a megera cartesiana. Quero ficar com o Tao, com os Vedas e Upanixades, com os Evangelistas e São Paulo, com Platão, com Plotino, com Bérgson, com Berdiaeff - com Cristo, principalmente.” (BIZZARRI, 2003: 90)

E, ainda sobre "O recado do morro", na mesma carta, em tom operatório, Rosa prossegue:

“(...) E a canção, o ‘recado’ opera, afinal, funciona. Mas Pedro Orósio - que sempre, de todas as vezes, estivera presente, mas surdo, sem compreensão, nos momentos em que cada elo se ligava, só consegue perceber e receber a revelação (ou profecia, ou aviso), quando sob a forma de arte. E, mesmo, só quando se entusiasma (V. etimologia: en-theos... ${ }^{58}$ ) pela canção, e canta-a." (2003: 92-93)

Voltando às palavras de Bento Prado Jr. (1985), em Guimarães Rosa, “todo sentido explícito nada mais é do que a cifra que pode conduzir o olhar sábio ao verdadeiro sentido que aponta e esconde ao mesmo tempo.” (p. 223). Pela voz de Riobaldo: Não convém a gente levantar escândalo de começo, só aos poucos é que o escuro é claro. (GSV, p. 207)

Percorridos esses encantados - e, como diria Riobaldo, encantoados - caminhos e descaminhos em meio a um sertão que é todo ele de grandeza cantável - mas, ao mesmo tempo, de vida muito discordada, com partes e artes, pactos e neblinas -, damos prosseguimento, ainda fazendo eco ao jagunço Tatarana, em nossas erranças na busca do decifrar da canção de Siruiz e do alento, fôlego, ânimo, necessário para tamanha empreitada.

\footnotetext{
${ }^{57}$ Nesta mesma carta (2003: 90), Rosa chega a dar pontos ao que Arroyo, in: Cultura Popular no Grande Sertão: Veredas. Rio de Janeiro: Livraria José Olympio Editora, 1984, p. 5, trata como "cada uma das prevalências da inspiração e da intuição no [seu] trabalho de criação e composição". Escreve Rosa a Bizzarri: "[...] com apreço de essência e acentuação, assim gostaria de considerá-los: a) cenários e realidade sertaneja: 1 ponto; b) enredo: 2 pontos; c) poesia: 3 pontos; d) valor metafísico-religioso: 4 pontos. Naturalmente, isto é subjetivo, traduz só a apreciação do autor, e do que o autor gostaria, hoje, que o livro [referindo-se ao Corpo de baile] fosse."

${ }^{58}$ A palavra entusiasmo vem do grego en-theos-asm que significa "sopro de Deus dentro".
} 


\section{A TOADA TODA ESTRANHA}

Siruiz: cantiga, estúrdia, que reinou para mim no meio da madrugada [...]; aquilo molhou minha ideia.

(Grande sertão: veredas, Guimarães Rosa) ${ }^{59}$

Benedito Nunes publicou, entre os anos de 1962 e 1967, numa série de cinco artigos reunidos mais tarde no volume $O$ dorso do tigre ${ }^{60}$, estudos seus que aproximam a obra de Guimarães Rosa a Platão, a Plotino e à alquimia - herdeira da tradição neoplatônica e hermética. Afirma Nunes, logo no primeiro dos cinco artigos da coletânea, intitulado $O$ amor na obra de Guimarães Rosa - estudo esse que se propõe a tematizar a relação do amor com o platonismo e o neoplatonismo nas obras Grande sertão: veredas, Corpo de baile e Primeiras estórias:

[...] a tematização do amor, na obra de Guimarães Rosa, repousa principalmente nessa ideia mestra do platonismo, colocada, porém, numa perspectiva mística heterodoxa, que se harmoniza com a tradição hermética e alquímica, fonte de toda uma rica simbologia amorosa, que exprime, em linguagem mítico-poética, situada no extremo limite do profano com o sagrado, a conversão do amor humano em amor divino, do erótico em místico. Tal seria a síntese da visão erótica da vida entranhada na criação literária de Guimarães Rosa. (2009: 138-139)

Em outro trecho do mesmo artigo, Nunes é ainda mais objetivo ao traçar relações entre a tradição alquímica e o romance Grande sertão: veredas como um todo - não apenas no que diz respeito à temática amorosa:

Em Grande sertão: veredas, Riobaldo, o jagunço, reclama uma justa separação entre o bem e o mal: que esses opostos se excluíssem e que de um deles nada permanecesse no outro. "Ao que - concluía ele vendo que pedia o impossível - este mundo é muito misturado". ${ }^{61}$ No menino os opostos se conciliam, e deles, por uma espécie de transubstanciação alquímica da alma, ao cabo da qual a vida se renova, ganhando inéditos esplendores, nasce a harmonia superlativa de que falava Heráclito. O Menino é uma criança qualquer a brincar com o seu macaquinho e é uma espécie de criança mítica, através de quem tudo se ordena, tudo se corresponde e tudo se completa." (2009: 153)

Seguindo as pistas suscitadas em $O$ dorso do tigre, ainda em busca das revelações da canção de Siruiz, vasculharemos um pouco mais as inspirações platônicas, neoplatônicas e herméticas na obra rosiana.

${ }^{59}$ Grande sertão: veredas. $19^{\mathrm{a}}$ ed. Rio de Janeiro: Nova Fronteira, 2001, p. 137.

${ }^{60}$ NUNES, Benedito. O dorso do tigre. São Paulo: Editora 34, 2009.

${ }^{61}$ Nas palavras de Riobaldo: Que isso foi o que sempre me invocou, o senhor sabe: eu careço de que o bom seja bom e o ruim ruim, que dum lado esteja o preto e do outro o branco, que o feio fique bem apartado do bonito e a alegria longe da tristeza! Quero-os todos pastos demarcados... Como é que posso com este mundo? A vida é ingrata no macio de si; mas transtraz a esperança mesmo do meio do fel do desespero. Ao que, este mundo é muito misturado... (GSV, p. 237) 
Aparentemente concordando com a máxima latina da Alquimia $^{62}$, solve et coagula ${ }^{63}$, oriunda provavelmente da Antiguidade Clássica ${ }^{64}$, a canção de Laudelim, de “O recado do morro", condensa coagula $^{65}$-, sob a forma de uma descantada melodia, todos os herméticos recados aspergidos, solvidos ou dissolvidos, durante a narrativa, revelando e decifrando, ao final da estória, o valioso "recado" mandado a Pedro Orósio pelo Morro da Garça, e tornando-o - transubstanciando-o - de pétreo, plúmbeo e pesado em volátil, apolíneo e etéreo.

Em Siruiz, todavia, e paradoxalmente, a canção já desponta na narrativa de forma condensada, cristalizada, construída e pronta, como que propondo, marotamente - feito as próprias artes de Hermes, artes essas tão caras a Rosa -, o caminho inverso da obra alquímica, coagula et solve, requerendo, como afirmaria Titus Burckhardt, em sua Alquimia, novamente voltar a solver-se para, também novamente, "voltar a cristalizar-se sob uma forma mais nobre." (1991: 125).

Essa parece ser uma chave bastante sedutora para a tentativa de elucidação dos herméticos desafios propostos pela canção de Siruiz, entretanto, levando-se em consideração alertas e suspeitas como as de Willi Bolle a respeito dos riscos de se atribuir demasiada importância às questões metafísicas nas interpretações rosianas $^{66}$, e fazendo alusão e eco aos conselhos de Riobaldo de que no cheio oco do escuro carece de acender mais fogueiras (GSV, p. 547), buscaremos tentar fugir à excessiva fixação em "fórmulas" já

\footnotetext{
${ }^{62}$ Não apenas NUNES, mas também UTÉZA, Francis, em seu JGR: A Metafísica do Grande Sertão, assim como muitos outros estudiosos da obra rosiana - além da própria biblioteca pessoal de Rosa, levantada por Suzi Frankl Sperber, in: Caos e cosmos: leituras de Guimarães Rosa. São Paulo: Duas cidades, 1976 - e as correspondências e as entrevistas do próprio autor denotam o quanto os estudos da alquimia sempre interessaram a Rosa. HAZIN (1991:58) afirma: "Acenando ao significado ideal mascarado pela narrativa real, Riobaldo é o símbolo vivo do relato que, sob o telúrico, e através dele, busca o metafísico."

${ }^{63}$ Princípio alquímico que, do latim, se traduz como "separar", "desmontar", "dissolver” e "juntar", "unir", "coalhar” e "coagular”. Princípio da transmutação dos metais e da natureza do homem através do conhecimento. O chumbo, por exemplo, representaria a ignorância e o desconhecimento das coisas sábias e sagradas, o homem profano, ignorante, e o ouro representaria o sábio. Para Titus Burckhardt, in: Alquimia. Lisboa: Dom Quixote, 1991, p. 125, assim deve proceder o alquimista: "De acordo com o tema solve et coagula, ele dissolve as concreções imperfeitas da alma, redu-las à sua matéria e, posto isso, trata de as voltar a cristalizar sob uma forma mais nobre". Para Angelus Silesius místico cristão citado por Sperber como uma das leituras de Rosa -: "O chumbo transforma-se em ouro, e o acaso dissipa-se quando, com Deus, eu sou transformado por Deus em Deus." (CHEVALIER E GHEERBRANT, 2000: 38)

${ }^{64}$ BURCKHARD, Titus, in: op. cit., relaciona a alquimia e o tema solve et coagula com a medicina grega nomeada por Paracelso como "Medicina Espagírica", denotando que esse tema deriva dos vocábulos gregos spao e ageiso. (1991: 24)

${ }^{65}$ Merece nota o nome de um dos recadeiros de "O recado do morro", o Qualhacôco, que se propõe ao necessário caminho do qualhar, do coagular, as dispersas, dissolvidas, mensagens destinadas a Pedro Orósio, totalmente cristalizadas, após, apenas por Laudelim.

${ }^{66}$ BOLLE, Willi, in: grandesertão.br: o romance de formação do Brasil. São Paulo: Duas Cidades; Ed. 34, 2004, ao tratar do que chama de "leituras existenciais, esotéricas e metafísicas" da obra rosiana, sugere prudência ao seu leitor:

Convém lembrar que a tendência da recepção, da década de 1950 até a década de 1990, de privilegiar leituras existenciais, esotéricas e metafísicas, foi fomentada significativamente por declarações do próprio Guimarães Rosa, o qual - com o prestígio e a autoridade do escritor consagrado - valorizou a dimensão "metafísico-religiosa" de sua obra em detrimento da "realidade sertaneja". Além disso, o longo período da ditadura militar (1964-1985) foi propício para um aniquilamento do ethos histórico. Assim, houve durante muito tempo uma certa acomodação da crítica e do público diante do "grande autor" - no que pesou também a dificuldade da obra. De acordo com uma fórmula, da qual talvez não exista registro escrito, mas que circulou entre os comentaristas, Guimarães Rosa era um "revolucionário da linguagem, mas politicamente reacionário".

Nesse período, contudo, foi diagnosticado um traço estilístico fundamental do autor de Grande Sertão: Veredas. De acordo com Walnice Galvão (1972), ele "dissimula a História, para melhor desvendá-la". A História e a "realidade brasileira" não são, portanto, problemas secundários em Guimarães Rosa: o que existe é a dificuldade de se elaborar instrumentos teóricos adequados para interpretar esses componentes da obra. (p. 25-26)
} 
demasiado seguidas. Seremos precavidos e deixaremos, ao menos por enquanto, e, na medida do possível, a tentação dos estudos alquímicos e neoplatônicos de lado - sem conseguir escapar, por certo, de todo disso, afinal estamos diante da obra de Guimarães Rosa e da canção de Siruiz -, e intentaremos nos focar em bases um pouco mais racionais, concretas, visando à sustentação imediata da pesquisa e a manutenção da "mira" 67 também na concretude cotidiana da "realidade sertaneja". ${ }^{6}$

Após breves citações, análises e alusões interpretativas à canção de Siruiz por Albergaria (1977) e Rosenfield (1993) - que relacionavam o canto, anagramaticamente, aos interesses metafísicos de Rosa pela estrela Sirius e pelo mito do deus egípcio Osires -, cronologicamente, Davi Arrigucci Jr., em seu magistral ensaio "O mundo misturado: romance e experiência em Guimarães Rosa", parece ser um dos primeiros a chamar nossa atenção, pelo menos de forma mais objetiva, categórica - menos “esotérica”, como diria Willi Bolle, referindo-se aos estudos anteriores -, para a importância da enigmática canção de Siruiz, "forma híbrida de narração épica e de instantâneo lírico", no decifrar da "travessia individual" de Riobaldo e da "vasta poesia épica do sertão" do romance Grande sertão: veredas. Para Arrigucci Jr., a balada contém “cifrada em suas palavras enigmáticas" o "destino de Riobaldo”. E o crítico literário prossegue: “Desse fundo obscuro da poesia oral vai desenrolar-se a história de sua vida. O Grande Sertão: Veredas é o desdobrar-se dessa balada" (1994: 27).

Muito antes, porém, em carta datada de 29 de outubro de 1963, enviada ao cônsul geral do Brasil, em Munique, Mário Calábria, o próprio Guimarães Rosa já tratava da importância dessa canção - e dos enigmas que a envolviam e ainda a envolvem - no romance Grande sertão: veredas:

Pois bem - e posso dizer, porque outro crítico, que não tenho à mão para aqui transcrever, já o notou e revelou, também - acontece, no livro, a certo momento esta coisa: É que na página $306^{70}$, da primeira edição, começa um parágrafo enorme que dura quatro páginas. Começa com "Urubu?..." naquela página. E vai terminar na página 309. POIS BEM, nesse longo parágrafo, mais ou menos no meio do livro, o que temos é uma exposição, entrecruzada, de todos os motivos principais - sobre glosa, alongada, da canção de Siruiz. Um trançadinho de motivos; que são, aliás, muitíssimos mais do que os que o A. C. ${ }^{71}$ aponta.

\footnotetext{
${ }^{67}$ Há um leitmotiv insistentemente reiterado - aliás, 12 vezes - no Grande sertão: veredas: o mire e veja. Tomamos o cuidado, neste estudo, de atentar para os diversos campos de visão e possibilidades de interpretação da canção de Siruiz, tentando fugir à interpretação exclusivamente metafísica e simbólica, mas, e ao mesmo tempo, evitando transformar em apenas alegórico o que também pode ser tratado por seu viés simbólico. Acreditamos que uma leitura que se propõe demasiado alegórica da obra, demasiado "mirada" - como, por exemplo, aquela sobre a qual se debruça Willi Bolle, mesmo levando-se em conta sua inquestionável contribuição para a fortuna crítica do autor -, pode, pelo menos, incorrer num possível empobrecimento do caráter plurissignificativo de suas linhas, impedindo-nos de "ver" aspectos importantes da inventiva criatividade rosiana.

${ }^{68}$ Antes desse mergulho abissal, vale ainda uma advertência, na voz de Riobaldo, a respeito de si próprio e de sua relação com a canção de Siruiz: Sou um homem ignorante. Gosto de ser. Não é só no escuro que a gente percebe a luzinha dividida? Eu quero ver essas águas a lume de lua. (GSV, p. 325)

${ }^{69}$ ARRIGUCCI Jr., Davi. “O mundo misturado: romance e experiência em Guimarães Rosa”, in: Revistas Novos Estudos CEBRAP (40). São Paulo, outubro, 1994, p. 7-29.

${ }^{70} \mathrm{Na}$ edição que tomamos por referência, da Nova Fronteira (2001), a glosa, num trançadinho de motivos, vai da pág. 325 a 329 , também no meio do livro, também em quatro páginas.

${ }^{71}$ Acreditamos que Guimarães Rosa referia-se a Antonio Candido.
} 
Elizabeth Hazin, em No nada, o infinito ${ }^{72}$, pioneiro estudo de crítica genética sobre o processo de criação do Grande sertão: veredas, também já denotava, no início da década de 1990, a importância da glosa do meio do romance para a compreensão dos desdobramentos da canção de Siruiz no todo narrativo e do hermenêutico processo de interpretação e de recriação da realidade em Rosa:

[...] tal trecho é o que corresponde à metade, rigorosamente exata, do livro. Explica-se a escolha dele [no estudo], por retratar fielmente o personagem, resumo que é de toda a sua vida, por ele próprio narrada. Difere do resto do livro, na medida em que, sozinho, contém o livro inteiro: microimagem da macroimagem [...] o trecho contém uma espécie de desdobramento da Canção de Siruiz, como foi mostrado anteriormente ${ }^{73}$, circunstância que lhe confere significado especial no fluxo narrativo. Além disso, é um divisor de águas, cortando o livro em metades bem distintas, as quais simbolizam os dois modos de narrar o mesmo, empreendidos por Riobaldo. (1991: 98)

${ }^{72}$ HAZIN, Elizabeth. No nada, o infinito (da gênese do Grande sertão: veredas). São Paulo: Tese de Doutorado FFLCH-USP, 1991.

${ }^{73}$ HAZIN já havia tratado minuciosamente da importância da glosa e da canção de Siruiz para os estudos do Grande sertão: veredas (as referências dizem respeito à $10^{\mathrm{a}}$ ed. Rio de Janeiro: José Olympio, 1976, pela pesquisadora consultada) na introdução de sua tese, abaixo transcrita:

Cito como exemplo o trecho impresso nas páginas 235-237 - que correspondem rigorosamente à divisão do livro em suas duas metades -, no qual pode ouvir-se nitidamente o eco da "Canção de Siruiz", a mesma que reinou estúrdia para Riobaldo no meio da madrugada.

Assim, para os versos da canção

Urubu é vila alta

mais idosa do sertão (GSV, p. 93)

temos o trecho do Grande sertão: veredas mais adiante que lhes corresponde

Urubu? Um lugar, um baiano lugar, com as ruas e as igrejas, antiquíssimo para morarem famílias de gente (...) Estive nessas vilas, velhas, altas cidades. (GSV, p. 235)

Seguindo:

padroeira minha vida

Mas minha padroeira é a Virgem, por orvalho. Minha vida teve meio-do-caminho?

vim de lá, volto mais não...

vim de lá, volto mais não?...

saí, vim, destes meus Gerais: voltei com Diadorim. Não voltei? Travessias... [saí?]

Corro os dias nesses verdes,

Diadorim, os rios verdes.

meu boi mocho baetão:

A lua, o luar: vejo os vaqueiros que viajam a boiada, mediante o madrugar.

buriti - água azulada

Buriti quer todo azul, e não se aparta de sua água - carece de espelho.

carnaúba - sal do chão...

Ao que Joca Ramiro pousou que se desfez, enterrado lá no meio dos carnaubais, em chão arenoso salgado.

Remanso do rio largo,

Otacília sendo forte como a paz, feito aqueles largos remansos do Urucúia

viola da solidão:

Ele está sempre longe. Sozinho. Ouvindo uma violinha tocar, o senhor se lembra dele.

quando vou p'ra dar batalha,

Tenho medo? Não. Estou dando batalha.

convido meu coração...

E meu coração vem comigo.

Se atentarmos ao que vem dito imediatamente antes e depois do trecho correspondente às páginas 235 - 237, veremos que este (inequívoco intervalo entre as duas partes) acha-se incrustrado entre duas observações de Riobaldo, a respeito da própria narração de sua vida. Se antes do trecho, afirma que seu interlocutor já sabe tudo, que tudo lhe fiou - "Aqui eu podia por ponto" (GSV, p. 234) -, depois ajunta: “Agora no que eu tive culpa e errei, o senhor vai me ouvir" (GSV, p. 237), mostração clara de que é preciso recontar para que as coisas se esclareçam." (p. 31-32). 
Além de Albergaria, Rosenfield, Arrigucci e Hazin, Francis Utéza, em seu JGR: Metafísica do Grande Sertão ${ }^{74}$, publicado em 1994, já abordava a importância da canção de Siruiz e da glosa fornecida pelo próprio Rosa, na voz de Riobaldo, tratando-os como o que considerava ser o "coração do GSV":

“(...) ao relatar sem transição um amalgama de dados fundamentais da sua vida, na imensa espiral de um stream of consciousness em cujo centro inscreve-se uma chamada de atenção - O senhor se alembra da canção de Siruiz? - o narrador convida-nos a interpretar a canção como uma mensagem portadora da trama de seu destino pessoal." (1994: 268)

Riobaldo, o narrador-protagonista de Grande sertão: veredas, com o falecimento da Bigri, sua mãe, vai morar na fazenda do padrinho Selorico Mendes - que, mais tarde, descobriria ser seu pai. Nessa fazenda, de nome São Gregório, o ainda menino Baldo, bastardo e órfão de mãe, trazendo tudo o que lhe restava em uma trouxa, por causa das chuvas numa viagem durada de seis dias (GSV, p. 127) - remontando, aliás, ao Gênesis bíblico -, abandona sua primeira infância e inicia, sem saber, a travessia rumo à vida adulta. Para tanto, vive alguns acontecimentos que lhe são fundantes. Dentre outros, dois deles, supostamente ocasionais, o impressionaram tanto e tão profundamente que se tornaram determinantes para os rumos que daria a sua vida: a chegada de Joca Ramiro com o seu bando e a canção boiadeira que ele ouviu da voz de um dos jagunços, o chamado Siruiz, após um pedido tão encantador e encantatório quanto a audição da própria canção: "Siruiz, cadê a moça virgem?" (GSV, p. 135)

Quando os jagunços chegam à Fazenda São Gregório, numa inesquecível madrugada de maio ${ }^{75}$, e se apresenta para Riobaldo o mundo das armas e da guerra, esse já surge sob a forma épico-lírica de uma balada, e como um letrado, um cantado enigma a ser decifrado. Assim descreve Riobaldo, entusiasmado, a primeira vez que ouviu a anônima balada boiadeira: a canção de Siruiz, cantiga, estúrdia, que reinou para mim no meio da madrugada [...] aquilo molhou minha ideia. (GSV, p. 137).

Logo após, em três momentos distintos e subsequentes do mesmo trecho narrativo, o narrador sertanejo enfatiza a aparente importância genésica, primordial, de a noite da primeira audição da canção de Siruiz ter

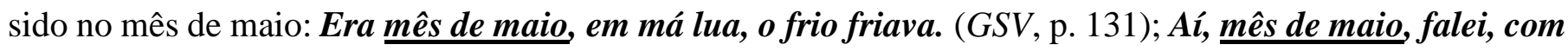
a estrela d'alva. O orvalho pripingando, baciadas. [...] (GSV, p. 133); Vinham quebrando as barras. Dia de maio, com orvalho, eu disse. Lembrança da gente é assim. (GSV, p. 136)

\footnotetext{
${ }^{74}$ UTÉZA, Francis. João Guimarães Rosa: Metafísica do Grande Sertão; tradução: José Carlos Garbuglio. São Paulo: Editora da Universidade de São Paulo, 1994.

${ }^{75}$ Faz-se importante lembrar que também o primeiro encontro de Riobaldo com o Menino - mais tarde nomeado Diadorim -, na travessia do deJaneiro, ocorreu no mês de maio - (...) porque se estava no mês de maio, digo, tempo de comprar arroz, quem não pôde plantar. (GSV, p. 120) - e a chegada do bando de Riobaldo à fazenda Santa Catarina, momento do primeiro encontro do jagunço com Otacília, sua futura esposa, também se deu em maio - A gente estava em maio. Quero bem a esses maios, o sol bom, o frio de saúde, as flores no campo, os finos ventos maiozinhos. (GSV, p. 205); Mas a lua subia estada, abençoando redondo o friinho de maio. (GSV, p. 212); E era em maio, pousamos lá dois dias, flor de tudo, como sutil suave, no conhecimento meu com Otacília. (GSV, p. 323). Primeiro encontro com Diadorim, primeiro encontro com Otacília, primeiro encontro com a jagunçagem e com a canção de Siruiz, tudo no mês de maio, mês a quem o narrador mais quer bem.
} 
Tentando, novamente, não deixar de lado os conselhos e passos propostos por Bolle (2004), e evitando uma interpretação de valorização excessivamente metafísica e simbólica de Grande sertão: veredas em detrimento da "realidade sertaneja", fincando nossos pés no chão, rastreamos pegadas concretas a respeito da relação entre o mês de maio e a gênese do romance.

Sandra Vasconcelos, em "Sertão e memória: as cadernetas de campo de Guimarães Rosa"76, lembranos da importância da incursão empreendida por Rosa, acompanhando uma boiada conduzida por Manuel Nardy e outros boiadeiros, nos sertões do norte de Minas, arredores de Cordisburgo - que também aconteceu num mês de maio, no ano de 1952 - para a construção das novelas de Corpo de baile e do romance Grande sertão: veredas, ambos publicados quatro anos depois. Assim afirma Vasconcelos:

O que Rosa viu, ouviu e viveu ficou registrado na famosa cadernetinha espiralada escrita a lápis em letra irregular (certamente devido ao balanço do cavalo) e em duas pastas datiloscritas, que chamou de A Boiada I e A Boiada 2, cujas anotações foram posteriormente aproveitadas na elaboração principalmente das novelas de Corpo de Baile e cujo conteúdo, composto de frases e palavras, cenas e paisagens, romances, desafios e lundus, traz observações fragmentadas do cotidiano dos boiadeiros e homens do sertão com quem o escritor conviveu nesse período [...] Apesar de se constituírem em um conjunto de anotações fragmentárias, os dois diários permitem recompor o trajeto do escritor. Em larga medida, um itinerário que revela algumas intersecções com os caminhos trilhados pelos jagunços de Grande Sertão: Veredas, em sua demanda pelos campos gerais, e se configura como uma espécie de mapeamento da paisagem das narrativas de Rosa. (2011: p. 189-190).

Talvez Rosa tenha escolhido o mês de maio para a composição do cenário da primeira audição da canção de Siruiz por Riobaldo e do primeiro encontro dele com o mundo da jagunçagem - além dos cenários dos outros importantes eventos do Grande sertão: veredas, ocorridos também no mês de maio e apontados em nota neste estudo - apenas para poder ser o mais fiel possível aos dados e detalhes da paisagem e da realidade sertanejas por ele colhidos e registrados em sua caderneta durante esse outro maio que foi o de sua viagem sertaneja ${ }^{77}$ de 1952, entretanto, relembrando que, em Rosa, como bem afirma Arrigucci (1994), tudo está misturado, e sabendo-se dos interesses do autor e de suas predileções por leituras clássicas, acreditamos não poder parar por aí e, portanto, tentando manter nossos pés na terra, mas, ao mesmo tempo, mirando e vislumbrando o céu, ousaremos arriscar, nas próximas linhas, um mergulho comparativo entre a tradição sertaneja e de cor local com aspectos míticos e metafísicos da tradição universal no que dizem respeito a esse mês que foi tão importante para os antigos gregos e romanos - e mesmo para as culturas orientais - e ainda

\footnotetext{
${ }^{76}$ ROSA, João Guimarães. A boiada. Rio de Janeiro: Nova Fronteira, 2011, p. 187-202.

${ }^{77}$ Em entrevista livre com Franklin de Oliveira, em janeiro de 1986, no Rio de Janeiro, HAZIN ouviu do estudioso e amigo pessoal de Rosa que uma das maiores ambições do autor era ser o mais fiel possível aos seus registros da realidade sertaneja: "A paisagem, a flora, o clima, tudo tem o toque do real, característica maior da obra de arte, na concepção de Guimarães Rosa, a sua maior ambição, confessada a Franklin de Oliveira" (1991: 218).
} 
é tão importante para a tradição ocidental - inclusive a popular e sertaneja -, tratando-os, já, como outras possíveis pistas para a tentativa de decifração da canção.

Em Fastos $^{78}$, elegíaco poema que aborda a religião romana e seus costumes, estruturado pela sequência dos feriados romanos de janeiro a junho, Ovídio trata o mês de maio como o "mês do conhecimento". Esse mês recebeu este nome em homenagem à Maia, ninfa grega da fertilidade, deusa romana de mesmo nome da fecundidade, que abrigava seus amores com Zeus - ou Júpiter, dentre os romanos - em uma caverna e que, na tradição romana, personificava o despertar da primavera. O filho de Maia com Zeus foi o deus Hermes o Mercúrio romano -, tido ao mesmo tempo como o deus da alquimia, do hermetismo e da hermenêutica, ou seja, do mistério hermético e da arte de decifrá-lo. Alguns estudiosos afirmam que a Maia dos gregos e romanos se originou do nome da mãe do Buda dos orientais. Afirmam Chevalier e Gheerbrant (2000: 583) que, em sânscrito, "Maia significa, no pensamento védico, a ilusão a que se reduz este mundo das aparências, pois ele não passaria de fruto de uma operação mágica dos deuses”.

Para Utéza, fazendo alusão às leituras alquímicas de Guimarães Rosa ${ }^{79}$, a insistência com que o narrador se refere ao mês de maio não é fortuita: "é no intervalo entre os signos de Áries e Touro que se recolhe a energia celeste indispensável para a primeira etapa da Obra, quando esta energia se espalha com maior abundância na terra, graças ao orvalho. ${ }^{80}$ (1994: 265)

Dos céus de Utéza ao chão de Bolle, ambos abordando, cada um ao seu modo, em dialética fusão de opostos, a "realidade sertaneja" de um Rosa que, em verdade, é tantos, é tudo, temos, ainda, que no mês de maio, no sertão mineiro, colhe-se o arroz semeado na primavera, festeja-se essa colheita, e lavram-se os campos que hão de ser semeados no outono.

Maio: mês da colheita do arroz ${ }^{81}$; mês das noivas; mês das mães; mês de Maria, mãe de Jesus, para a tradição cristã; mês de Maia, mãe de Hermes, de Mercúrio e do Buda, segundo as tradições greco-romana e orientais; mês da fecundidade, da prosperidade e da magia - ou da alquimia -; mês da real incursão de Rosa pelos sertões mineiros de 1952; mês da não menos real travessia de Riobaldo e do Menino, em bamba canoa, pelo de-Janeiro; mês da chegada à fazenda Santa Catarina - a do sertão das cadernetas de Rosa, a do sertão

\footnotetext{
${ }^{78}$ Palavra derivada do termo latino "fas", que significa "aquilo que é permitido", ou seja, "o que é legítimo aos olhos dos deuses".

${ }^{79}$ Utéza também cita a lista de títulos da biblioteca pessoal de Rosa apresentada, em resumo, como apêndice para a tese de doutorado de Suzi F. Sperber, intitulada como Cosmos e Caos. São Paulo: Duas Cidades, 1976, p. 159 a 201.

${ }^{80}$ Dentre outros, para tratar das relações entre o mês de maio, o orvalho e os estudos alquímicos de Rosa, Utéza cita, em nota, a quarta prancha do Mutus Liber, importante referência alquímica, "onde se vê um casal de alquimistas recolhendo a flos coeli que servirá para animar a MatériaPrima, transmitindo-lhe a Força e a Vida" (2004: 265). ROOB, Alexander, in: Museu Hermético - Alquimia e Misticismo. GmbH: Taschen 2006, p. 308, assim analisa essa prancha: "O casal alquímico como correspondência inferior ao Sol e à Lua na recolha do orvalho, que deve ocorrer nos meses de Abril (Carneiro) e Maio (Touro), quando o espírito verde do cosmos, de que Khunrath tanto falou, está na sua maior pujança. O orvalho hermético é também designado como 'o vitríolo dos filósofos'. O seu glifo está representado no cimo da torre da igreja, à direita.".

${ }^{81}$ Segundo CHEVALIER \& GHEERBRANT (2000: 82), o arroz, considerado "de origem divina", simboliza, no mundo oriental, a riqueza, a abundância, a pureza primeira. No ocidente, ele é símbolo da felicidade e da fecundidade, por isso, até hoje, lançam-se punhados de arroz sobre os noivos nas cerimônias de casamento de todo o mundo.
} 
do romance de Riobaldo -; mês do primeiro encontro com Diadorim; mês do primeiro encontro com Otacília; mês do primeiro encontro com a jagunçagem e da primeira audição da epifânica canção de Siruiz.

Riobaldo, ao buscar, a mando do padrinho-pai, naquela orvalhada noite de outono de mês de maio, um lugar para esconder os jagunços de Joca Ramiro e juntando-se ao bando de cavaleiros que esperavam fora da casa-da-fazenda, ouve, na transição da noite para o dia, promessa de encontro entre lua e sol, alguém perguntar alto "Siruiz, cadê a moça virgem?", e escuta Siruiz cantar a toada toda estranha que, feito o orvalho da noite, molha sua ideia e, tal e qual uma epifania, o encanta.

Trataremos depois do enigma da "moça virgem", que é, ao mesmo tempo, "padroeira" e prenúncio da “donzela guerreira”, Diadorim/Maria Deadorina, neblina de olhos verdes, na qual Riobaldo se acolheu e se abismou, do qual se alimentou e jejuou. Por enquanto, tentando decifrar cada detalhe da canção de Siruiz e do seu epifânico contexto, focar-nos-emos prioritariamente nas pistas por eles suscitados e na importância do orvalho para a cultura sertaneja e, em particular, para Rosa e sua "misturada" escritura - e não menos "misturada" atenção às coisas físicas e metafísicas.

Nas cadernetas datiloscritas de 1952, publicadas em edição fac-símile em A boiada (2011), encontramos algumas anotações de Rosa que dizem respeito ao peculiar interesse do autor pelo orvalho no que tange à realidade sertaneja. Transcrevemos, a seguir, aquelas que julgamos mais importantes:

10.V.52 - No trem. 9 horas da manhã. Não só a relva, mas as folhas das árvores se molharam em prata de orvalho. (Esta madrugada, deitado, via a lua, já baixa, lua cheia, pronta a ir-se. (Lado meu era o do poente) Poente da lua cheia (ainda alto, eclipsado). Depois, às 4hs.30', as nuvens cinzento-verdes, leves. Hora em que as nuvens (isoladas) refletem os verdes do mundo. Depois, elas ficam azul e rosa.) (2011: 28)

Hoje, domingo, 25-V-52.

Ao sol, orvalhado e belo, o meloso florido. Seu perfume.

A poeira ainda está "pesada" (está mais pesada), por causa do orvalho. Bom, para o gado e para a gente. (De madrugada, ela está molhada.)

(O que mais molha de orvalho é o feijão e o capim, E as árvores mais copadas.) (2011: 163)

28.V.52.

Às seis horas da manhã. Claridade da madrugada. O sol ainda não saiu. "Está clareando agora, resumindo". "Romper a aurora". Perto de nós, o grosso, enorme rôlo reto, de bruma branca (fumaça) ("fumaça") desce da bocaina pela baixada. Sôbre êle o outeiro, que marca o nascente. Grandes nuvens alaranjadas, que, a certa hora, se mudam em azuis - mas sôbre elas o céu se torna de difusos laivos côr de rosa, extensos. São agora riscos grossos, imensos, irradiados = aumentação dos raios do sol (parecem uma).

Maiora a claridade.

$[\ldots]$

A bruma sôbre o meloso.

Aruvalho (orvalho) pesa, 
Pesa na ponta da folha... $\left(\mathrm{m} \%{ }^{82}\right)$

$[\ldots]$

“- Um aruvalho nojento!” ...

O sol saindo (subindo), nossas sombras ficando grandes. (engrandecendo).

m\%: tema: o que parece grandeza nossa, é coisa mera, passageira e falsa - como o engrandecer das sombras... (2011: 182-183)

No Aurélio $o^{83}$, encontramos as seguintes definições para orvalho: " $S$. $m$. 1. Umidade da atmosfera, que se condensa (principalmente durante a noite) e se deposita, em forma de gotículas, sobre qualquer superfície fria; relento, rocio. 2. Chuva muito miúda; chuvisco. 3. P. ext. Líquido que se espalha em pequenas gotas: orvalho de lágrimas. 4. Fig. Aquilo que refrigera, acalma, consola: os orvalhos da graça de Deus."

Para o sertão e as paisagens sertanejas, como vimos nos registros datiloscritos da caderneta de Rosa, o orvalho, além de embelezar as madrugadas enluaradas, "molhando em prata" as paisagens e tornando a relva mais verde e as flores mais coloridas e perfumadas, ainda refrigera, refresca, acalma, protegendo contra o calor e, por conta do "peso" úmido que deposita sobre a poeira, baixando-a no solo, facilita o labor, a lida boiadeira, e a travessia de gente e do gado.

Contudo, acreditamos não ficar apenas nisso a importância da insistente referência ao orvalho em Grande sertão: veredas - e em outras tantas das obras rosianas ${ }^{84}$. Aparentemente, não há acaso também nessa escolha. Muitas são as tradições conhecidas e estudadas por Rosa que relacionam o orvalho com a sutil influência do céu sobre a terra ${ }^{85}$. Segundo Chevalier e Gheerbrant (2001), aliás, fazendo eco ao dicionário Aurélio, o orvalho se apresenta como expressão da "bênção celeste" e da "graça vivificante", como símbolo de redenção e de revivificação, tanto no Hermetismo quanto na Cabala judaica. Entre os hebreus, o "orvalho celeste" torna a dar vida às "ossadas dessecadas" e, para os chineses, o "orvalho lunar" aclara a visão e permite atingir a imortalidade.

Nos livros sagrados da Índia, assim como na Bíblia cristã, trata-se o orvalho como o símbolo da “palavra divina”: o “cântico de Moisés” (Deuteronômio, 32) começa com sua evocação: “Que minha doutrina

${ }^{82}$ Rosa utilizava-se do sinal $\mathrm{m} \%$ para tratar de algo que era cem por cento de autoria própria.

${ }^{83}$ FERREIRA, Aurélio Buarque de Holanda. Novo Dicionário Aurélio da Língua Portuguesa, Rio de Janeiro: Editora Nova Fronteira, s/d.

${ }^{84}$ Dentre outras, merece atenção a inscrição do orvalho - e do mês de maio - no início de "Substância", da obra Primeiras estórias. No primeiro parágrafo do conto, o narrador descreve a aproximação entre Sionésio e Maria Exita, protagonistas de uma sertaneja trama amorosa:

Sim, na roça o polvilho se faz a coisa alva: mais que o algodão, a garça, a roupa na corda. Do ralo às gamelas, das masseiras às bacias, uma polpa se repassa, para assentar, no fundo da água e leite, azulosa - o amido - puro, limpo, feito surpresa. Chamava-se Maria Exita. Datava de maio, ou de quando? Pensava ele em maio, talvez, porque o mês mor - de orvalho, da Virgem, da claridade no campo. Pares se casavam, arrumavam-se festas; numa, ali, a notara: ela, flor. Não lembrava a menina, feiosinha, magra, historiada de desgraças, trazida, havia muito, para servir na fazenda. Sem se dar ideia, a surpresa se via formada. Se, às vezes, por assombro, uma moça assim se embelezava, também podia ser sido no tanto-e-tanto. Só que, a ele, Sionésio, faltavam folga e espírito para primeiro reparar em transformações. (p. 185)

${ }^{85}$ Merece nota que mesmo o dicionário Aurélio, aqui tratado, faz referência ao simbolismo do orvalho, ao propor-lhe a definição: “os orvalhos da graça de Deus". 
jorre como a chuva, que minha palavra caia como o orvalho, como vagas sinuosas sobre a erva verdejante, como aguaceiros sobre a relva!’. Em outro trecho bíblico (Isaías 26, 19), o orvalho aparece também como símbolo de regeneração: “Acordai e estremecei de alegria, habitantes do pó, porque o orvalho é um orvalho revivificante, e a terra voltará a dar luz às sombras”. Entre os gregos, o orvalho está ligado aos mitos da fecundidade: Dioniso encarna o orvalho fecundante do céu. E, como já foi tratado em nota neste estudo, era no mês de maio que os alquimistas recolhiam o "orvalho hermético", "espírito verde do cosmos" "86 "vitríolo dos filósofos", para seus experimentos.

Refrigeração e regeneração do sertão e da vida sertaneja: fecundidade para a terra, umidade para as plantas, bebida lambida pelo gado, alento e consolo para os homens. "Bênção celeste”, "graça vivificante”, "palavra divina", "cântico de Moisés", "espírito verde do cosmos”, "vitríolo dos filósofos”, orvalhada canção de Siruiz molhando a ideia de Riobaldo. Pela narração do lírico jagunço, sob o rocio da madrugada, o epifânico roçar da canção e da voz de um cantador - retrasadas minudências do que não se pode esquecer:

A gente se encostava no frio, escutava o orvalho, o mato cheio de cheiroso, estalinho de estrelas, o deduzir dos grilos e a cavalhada a peso. Dava o raiar, entreluz da aurora, quando o céu branquece. Ao o ar indo ficando cinzento, o formar daqueles cavaleiros, escorrido, se divisava. E o senhor me desculpe, de estar retrasando em tantas minudências. Mas até hoje eu represento em meus olhos aquela hora, tudo tão bom; e, o que é,é saudade. (GSV, p. 134)

Merece atenção a bela e significativa análise que Utéza faz deste trecho de Grande sertão: veredas:

Enquanto o frio, sugerindo um movimento de recuo do herói - encostava -, se materializa em contrapeso da massa dos cavaleiros, na fronteira exata do dia e da noite instaurada pelo neologismo entreluz e o verbo raiar, coagulado como substantivo, todas as sensações se fundem numa vibração unitária: as mensagens sonoras transmitidas debaixo pelos grilos e pela queda dos pingos de orvalho englobam o cintilar das estrelas de cima - estalinhos -, bem como os cheiros que vão subindo do mato. E quando o narrador pretende pedir desculpas pela demora destas explicações, a ruptura do relato apenas torna mais sensível a suspensão da linearidade do tempo, suspensão concretizada no discurso pelos infinitivos substantivados e pelo próprio léxico - branquecer, eco de esbranquiçado, preferido ao vernáculo branquejar, e além disso suavizado pelo adjetivo cinzento, também ele moderado pela expressão indo ficando. De fracionamento em fracionamento, o tempo profano acaba por se imobilizar no Grande Tempo: Mas até hoje eu represento em meus olhos aquela hora, tudo tão bom; e, o que é, é saudade. (1994: p. 266)

\footnotetext{
${ }^{86}$ No primeiro trecho da caderneta de Rosa que diz respeito ao orvalho, neste estudo transcrito (p. 28), vemos a insistente referência ao verde nas anotações do autor sobre as madrugadas sertanejas: “[...] às $4 \mathrm{hs.30}$ ', as nuvens cinzento-verdes, leves. Hora em que as nuvens (isoladas) refletem os verdes do mundo."
} 
Luiz Roncari, em “A Canção de Siruiz Ziruis"87 (2004: 77), relembra que o jagunço-cantor Siruiz ${ }^{88}$ aliás nome de gênero tão indeterminado quanto Diadorim - e sua lírica e serenada canção boiadeira aparecem na narrativa de Grande sertão: veredas - e nas reminiscências da primeira infância de Riobaldo - nessa enluarada e orvalhada madrugada de maio, entre o cinza e o verde, logo após a apresentação do Hermógenes, de modo a contrastar com a figura grotesca e com a voz rosnada deste último. Como se a voz fosse a expressão da alma e do ser, do se-ir, de cada um, correspondendo ao mesmo tempo à sua aparência externa. A voz do Hermógenes parecia mais o urro de um bicho do que a fala de um homem, afirma Riobaldo:

O Hermógenes tinha voz que não era fanhosa nem rouca, mas assim desgovernada
desigual, voz que se safava. Assim -fantasia de dizer - o ser de uma irara, com seu cheiro
fedorento. [... Deu ainda um barulho de boca e goela, qual um rosno. (GSV, p. 134-135) Siruiz, ao contrário e como contraste, é evocado pela beleza da sua orvalhada voz: Um falou mais alto, aquilo era bonito e sem tino. (GSV, p. 137) E, ainda segundo Roncari, concordando com Arrigucci Jr, “ele [Siruiz] canta uma canção que soa estranha a Riobaldo e lhe chama a atenção, pois, na verdade, ela predizia e resumia a história de sua própria vida, que não tinha sido ainda vivida" (2004: 77).

Sim, tanto para Arrigucci Jr., quanto para Utéza, Roncari e outros já citados, aliás, retomando o próprio Rosa, a canção de Siruiz se mostra como uma cifrada chave de entendimento do desatinado destino de

${ }^{87}$ RONCARI, Luiz. O Brasil de Rosa: mito e história do universo rosiano - o amor e o poder, São Paulo: Ed. UNESP, 2004, p. 76 a 86.

${ }^{88}$ Como já mencionamos, alguns críticos, como Albergaria, Rosenfield e, após, Utéza, Araújo e Reinaldo relacionam o nome Siruiz com a estrela Sírius: "A estrela Sírius, quando aparece no Egito, é um índice de cheias no Nilo, anunciando um período de fertilidade e, por isso, é associada à deusa Isis”, afirma Reinaldo, parafraseando Albergaria, Rosenfield e Utéza (2005: 22). Rosenfield (1993: 13) aponta: “O estranho nome 'Siruiz' mantém relações com seus 'irmãos' anagramáticos Sírius e 'Osíres/ Usires"”. Utéza compara Siruiz à estrela Sírius: a mais brilhante do céu, estrela de Isis e Osires. (1994: 391). E Albergaria vai além em suas sugestões e especulações metafísicas:

Osíris prefigura o iniciado para quem a morte é apenas uma etapa no caminho da vida pneumática, após ter vivido, morrido e ressuscitado. É esta circunstância que faz dele o "Rei dos Mortos" a quem as almas devem se apresentar para julgamento no Tribunal de Osíris (...) Ao utilizar o anagrama Siruiz, atualiza-se em Grande sertão veredas a indicação do processo iniciático efetuado por Riobaldo, e interpretamos esta 'utilização' como um índice concedido pelo Autor numa forma de 'pista' que poderia ajudar na decifração do enigma” (1977: 92-94).

HAZIN (2001), contudo, desconfia dessa análise de Albergaria (que ecoa e reverbera nas outras citadas):

Ao analisar o romance por uma perspectiva ocultista, a autora levou longe demais seus pressupostos, procurando atribuir intenções esotéricas à formação de um nome que, assim decodificado, se adaptaria como uma luva ao esquema prévio de sua leitura. (...) O nome Siruiz origina-se de algo mais simples, menos transcendente, mas nem por isso, menos encantador. Ora, em minhas pesquisas no Arquivo [IEB] localizei folha solta com dez linhas escritas, todas precedidas do sinal $\mathrm{m} \%$, sob o título geral BOIADA. Uma delas (a sexta) diz: "Síruis (sic) a prumo - na minha meia-noite (E26, p. 34), numa clara alusão à estrela Sirius (note-se o i inicial proparoxítono), no alto do céu. Ao lançar a sentença no papel, todavia, Guimarães Rosa, distraidamente colocou o ponto do i final sobre o u, deslocamento que sugere ao leitor outra palavra, a palavra SÍRUIS, que efetivamente se lê. Suponho que, mais tarde, na fase da redação do Grande sertão: veredas, o escritor, ao reencontrar em sua anotação o vocábulo involuntariamente grafado - SÍRUIS - deve ter experimentado o efeito de uma revelação: algo desconhecido desvelou-se de súbito iluminado e o jogo recorrente das semelhanças e diferenças, e a analogia subjacente decidiram-no a inserir a palavra justamente numa situação noturna - madrugada alta - com estrelas no céu e os metamorfoseando em z, de forma a caracterizar em definitivo como oxítona a sílaba que sem querer tinha inventado. Reação espontânea produzida por um vocábulo que, por semelhança acidental com outro, é capaz de evocar uma imagem incongruente, muito afastada de sua verdadeira significação. (2001: p. 235-238)

Suspendendo julgamentos, vale a lembrança de que na obra GSV, como bem afirmou Candido (1978), "há de tudo para quem souber ler" e "cada um poderá abordá-la a seu gosto", e, aludindo Arrigucci Jr. (1994), no romance está "tudo misturado", até porque, como denota a própria Hazin (2001) “(...) Grande sertão: veredas é rede lançada, texto urdido pelo autor, onde aparece de tudo”. O próprio Guimarães Rosa, em carta de 21 de abril de 1958 a Vicente Ferreira da Silva - citada por Sperber (1976: p. 89) - endossa essa ideia:

(...) O Grande sertão: veredas - que, por bizarra que você ache a afirmativa, é menos literatura pura do que um sumário de ideias e crenças do autor, com buritis e capim devidamente semicamuflados. 
Riobaldo, de sua formação e aprendizagem e, consequentemente, do romance Grande sertão: veredas como um todo. Isso posto, "rondando os segredos de Guimarães Rosa" ${ }^{89}$, faz-se mister decifrar essa canção.

Mas, não sem, antes, fazer uma última consideração e apontamento: se, como afirma Utéza concordando com Galvão, em As formas do falso (1988: cap. 9), com Albergaria, em O Bruxo da linguagem (1977: 32), e com Nunes, em O dorso do tigre (2009: 153) -, a "alquimia" de Rosa é sempre uma tentativa de harmonizar os opostos, conceito de unidade fundada na dualidade, dialética contraposição e aproximação entre céu e terra, além do bem e do mal - confirmando a lição de Aleixo de que o Bem pode sempre nascer do Mal e de que, não há, portanto, nem Bem nem Mal absolutos ${ }^{90}-$, e se o sertão é o que dele se faz e se presume, como de formas tão diversas tantas vezes narrou Riobaldo, merece destaque o que Rosa diz a Günter Lorenz, no “Diálogo com Guimarães Rosa”, em Gênova, janeiro de 1965, a respeito de sua obra:

(...) no sertão, fala-se a língua de Goethe, Dostoievski e Flaubert, porque o sertão é o terreno da eternidade, da solidão, onde Ineers und Ausseres sind nicht mehr zu trennen ${ }^{91}$, segundo o Westöstlicher Divan ${ }^{92}$. No sertão, o homem é um $e u$ que ainda não encontrou um $t u$; por isso ainda ali os anjos ou o Diabo manuseiam a língua. O sertanejo, você mesmo escreveu isso, 'perdeu a inocência no dia da criação e ainda não conheceu o pecado original'. Ele está ainda além do céu e do inferno. (1991: 86)

Isso posto, sem separar exterior e interior, mas indo inicialmente do grande para o pequeno, continuemos nosso itinerário, agora, em busca das possíveis fontes de inspiração de Rosa para o mote da reveladora canção de Siruiz.

Riobaldo não é o primeiro e nem será o último personagem protagonista da tradição literária ocidental a ter seu destino, sua trajetória de vida e sua aprendizagem pressentidos e preditos por uma canção ou por enigmáticos versos que, inicialmente obscuros, cifrados, ainda que já anunciando uma espécie de epifania, de iluminação $0^{93}$, culminariam, ao final do percurso narrativo, em um instrumento de decifração e de

\footnotetext{
${ }^{89}$ Em artigo com este título, referente à primeira publicação de Corpo de baile (1956) - após também em ROSA, João Guimarães, Manuelzão $e$ Miguilim, 11 a ed. São Paulo: Editora Nova Fronteira, 2001, p. 17-25 -, Paulo Rónai aborda os enigmas e os segredos que se armam a cada passo do "verdadeiro labirinto" que é a escritura rosiana. Tratando de Corpo de baile da mesma maneira que poderia tratar de outra obra qualquer de Rosa, como, por exemplo, Grande sertão: veredas, o crítico afirma: "Como os grandes poemas clássicos, Corpo de baile está cheio de segredos que só gradualmente se revelam ao olhar atento. A própria unidade da obra é um deles. Ela não é apenas geográfica e estilística. Conexões de temática, correspondências estruturais, efeitos de justaposição e oposição integram-na, mas os leitores têm de descobri-los um a um. Talvez ninguém consiga, nesse pormenor, desemaranhar totalmente o jogo complexo das intenções do autor - mas o que cada um desvendar será o suficiente para intensificar o prazer da peregrinação por esse mundo denso de novidades".

${ }^{90}$ MAZZARI, Marcus Vinicius, in: Labirintos da Aprendizagem - Pacto fáustico, romance de formação e outros temas de literatura comparada. São Paulo, Editora 34, 2010, p. 39-40, retoma o caso de Maria Mutema, narrado em Grande sertão: veredas, por Jõe Bexiguento, para tratar da singular relação entre bem e mal no sertão rosiano: “(...) a mais extraordinária história da reversibilidade do mal para o bem, fazendo ressoar em pleno sertão um motivo presente no Hamlet shakespeariano (a substância letal inoculada ao ouvido da vítima adormecida) e trazendo também à lembrança a lenda em torno de Maria Aegyptiaca que, conforme narrado na coletânea Acta Sanctorum, é barrada à porta da igreja do Santo Sepulcro, em Jerusalém, por força misteriosa”.

91 "O interior e o exterior já não podem ser separados", escrito em alemão por Guimarães Rosa.

92 O divã oriental-ocidental, uma das principais obras de Goethe, citada em alemão por Rosa.

93 A fazenda de Selorico Mendes, primevo ponto de encontro entre Riobaldo e a canção de Siruiz, chama-se São Gregório e um dos nomes que esse santo peregrino recebe na liturgia católica é "O iluminador", por converter o povo armênio ao cristianismo.
} 
elucidação de sua travessia. Já vimos isso, por exemplo, com "O recado do morro", de Corpo de Baile, na própria obra anterior de Guimarães Rosa, mas, agora, chegou a hora de irmos além.

Murilo Marcondes de Moura, em seu ensaio "A canção de Siruiz"94, mesmo fazendo questão de evidenciar que a presença de versos é muito discreta em Grande sertão: veredas, chama a nossa atenção para a canção de Siruiz, que trata como uma espécie de "caroço da narrativa", "do qual esta se nutre e se expande", e para as semelhanças e as aproximações entre o texto em prosa poética de Rosa, publicado em 1956, e o prosimetrum medieval, Vita Nuova, de Dante Alighieri, escrito entre 1292 e 1294.

Vita Nuova que, numa espécie de antologia da primeira produção dantesca, conta a experiência amorosa do narrador com Beatriz desde seu primeiro encontro - quando ambos tinham perto dos nove anos de idade até pouco depois da morte dela -, além de ter, de forma semelhante com o Grande sertão: veredas, a narrativa pós-morte das amadas daqueles que narram - e afirma Moura que poderíamos concluir que "tudo o que se narra, na Vita Nuova, está se referindo a Beatriz, assim como tudo o que se narra, em Grande sertão: veredas, está, de algum modo, vinculado a Diadorim" -, ainda apresenta um outro, e mais singular, mote comum com o romance de Rosa: os epifânicos versos premonitórios.

A Vita nuova se inicia por um sonho, sonho esse que se apresenta ao narrador como uma "maravilhosa visão" e que se torna o tema principal do primeiro poema do livro - o soneto "A ciascun'alma presa e gentil core" ("A toda alma enamorada e de coração gentil") ${ }^{95}$-, poema esse tratado por De Roberts - e lembrado por Moura - como "sonetto-enigma"96.

Depois de comentar o poema, o narrador de Vita Nuova afirma: "Lo verace giudicio del detto sogno non fue veduto allora per alcuno, ma ora è manifestissimo a li più semplici”" (“O verdadeiro sentido do dito sonho não foi visto então por ninguém, mas agora é manifestíssimo aos mais simples”). Sim, assim como a canção de Siruiz prediz o que viveria o Jagunço Riobaldo, sua vocação para as armas e para as letras e sua trágica vivência amorosa com a morte de Diadorim, o sonho poetizado por Dante na forma de um soneto é interpretado como premonitório da morte de Beatriz e, de certa maneira, marca a introdução do neófito - e futuro guerreiro, também homem de letras e de armas - ao círculo dos poetas florentinos.

Insistindo - assim como Arrigucci Jr., Utéza, Hazin e Roncari, dentre tantos outros - na importância da canção de Siruiz para a narrativa rosiana, e fazendo alusão ao estudo de Sperber, já tratado nesta pesquisa,

\footnotetext{
94 Texto ainda não publicado, gentilmente cedido pelo Prof. Dr. Murilo Marcondes de Moura.

${ }^{95}$ A ciascun'alma presa e gentil core/nel cui cospetto ven lo dir presente,/in ciò che mi rescrivan suo parvente,/salute in lor segnor, cioè Amore.// Già eran quasi che atterzate l'orel del tempo che onne stella n'è lucente,/ quando m'apparve Amor subitamente,/cui essenza membrar mi dà orrore.// Allegro mi sembrava Amor tenendo/ meo core in mano, $e$ ne le braccia aveal madonna involta in una drappo dormendo.// Poi la svegliava, e d'esto core ardendo/ lei paventosa umilmente pascea:/ appresso gir lo ne vedea piangendo.
}

96 DE ROBERTIS, Domenico. Il libro della “Vita Nuova”. Firenze: Sansoni, 1970, p. 15 e 89. 
Moura, dialogando com Mazzari e seu "Veredas-Mortas e Veredas-Altas: a trajetória de Riobaldo entre pacto demoníaco e aprendizagem"97, sugere ainda a aproximação de Grande sertão: veredas também com outro importante romance de nossa tradição, a obra inacabada Heinrich Von Ofterdingen, de Novalis. E, entre os inúmeros liedern aí presentes, afirma merecer atenção especial a balada entoada pelo eremita que Heinrich encontra numa galeria subterrânea, com a qual, exatamente como se dá com Riobaldo em relação aos versos da canção de Siruiz ${ }^{98}$, também se pressente uma cifra do seu destino.

Antes, Francis Utéza, em seu JGR: Metafísica do Grande Sertão, também baseado nos levantamentos das leituras rosianas feitos por Sperber, trazia outro importante elemento comum entre as premonitórias canções criadas Rosa e por Novalis, a audição em manhãs de maio: “À semelhança de Henrique de Ofterdingen, Riobaldo teria ouvido, numa bela manhã de maio, o canto das profundezas, que, no mistério das origens, já encerrava o seu futuro inteiro" (UTÉZA, 1994: 268).

Moura, em diálogo com os outros críticos, observa, por fim, que, no romance de Novalis, assim como em Grande sertão: veredas, há a formação - ou a aprendizagem - de um poeta: “inicialmente, os liedern são compostos e cantados por outros; no final, quando o aprendizado vai se consolidando, Heinrich canta um poema de sua própria autoria, mais ou menos análogo ao que faz Riobaldo a partir da canção [de Siruiz]”.

E Mazzari, ainda em seu Labirintos da Aprendizagem, vai além nas relações entre o Grande sertão: veredas e o romance inacabado de Novalis, e na análise, em perspectiva de literatura comparada, do aprendizado de poesia e de guerra de Riobaldo e do jovem Heinrich:

[...] a empresa guerreira de Riobaldo e Diadorim contra as hostes de Hermógenes poderia lembrar também, em certos lances, a mitologização da guerra que Novalis empreende em seu Heinrich Von Ofterdingen - romance que, conforme demonstra Suzi Frankl Sperber, foi lido e anotado por Rosa. (2010: 45)

Ainda em perspectiva comparada e mantendo o foco na canção de Siruiz, por fim, fazendo alusão a outro estudo de Mazzari ${ }^{99}$, Moura destaca a aproximação entre Grande sertão: veredas e Os anos de aprendizado de Wilhelm Meister, de Goethe, e, em particular, evidencia o perturbador fascínio que as canções entoadas pelo harpista e por Mignon - sobretudo por Mignon - provocam em Wilhelm. Profundamente enigmáticas, essas canções, apenas ao final do romance, revelariam seu pleno sentido e sua importância na formação - na travessia - do protagonista.

\footnotetext{
${ }^{97}$ MAZZARI, Marcus Vinícius. Labirintos da Aprendizagem - Pacto fáustico, romance de formação e outros temas da literatura comparada. São Paulo: Editora 34, 2010. p. 17-91.

${ }^{98}$ Aliás, o jagunço-violeiro Siruiz muito tem de eremita, assim como a neblinada madrugada da chegada do bando de "foras-da-lei" à fazenda São Gregório também tem de "caverna subterrânea".

${ }^{99}$ MAZZARI, Marcus V. Apresentação Os anos de aprendizagem de Wilhelm Meister, Goethe, J. W. V. São Paulo: Editora 34, 2006 , p. 7-23.
} 
Vale ressaltar, finalmente, que não foram somente as canções, como "Conheces o país onde florescem os limoeiros" 100 , que, entoadas pelo harpista e por Mignon, "agradaram especialmente a nosso amigo [Wilhelm], ainda que não tivesse podido compreender todas as palavras (...)", mas houve também o atordoante fascínio de Wilhelm por Mignon: “Olhou assombrado aquela figura, sem poder atinar se devia tomá-la por um menino ou uma menina”. Como em Siruiz e Diadorim, há aí, novamente, uma indeterminação de gênero. E, como no fascínio de Riobaldo ante a canção de Siruiz - e em face do companheiro Diadorim/Deadorina -, os protagonistas deparam e se encantam com "algo" que é bonito e sem tino, harmonia em contrastes.

Partindo, agora, para a decifração da canção de Siruiz propriamente dita, salientamos que pretendemos, nesta pesquisa, sob uma perspectiva hermenêutica, do pequeno para o grande e do grande para o pequeno, analisar os elementos imanentes à anônima cantiga entoada por Siruiz, abstraindo-a da narrativa em que se acha incrustada e fazendo-a valer por si só, para, após, clarear os desdobramentos dessa epifânica balada boiadeira, de forma progressiva, incrustrada novamente nas linhas de Grande sertão: veredas, na glosa fornecida por Rosa, e na formação de seu narrador, o jagunço-poeta Riobaldo que, numa orvalhada madrugada de sua infância, serenado, a escutou e que, com ela, viu despertar sua vocação para as armas e para as letras, e seu trágico amor pela Moça Virgem, o jagunço Diadorim.

Tentaremos, inclusive, buscar caminhos de interpretação para as coplas compostas pelo próprio homem de letras, poeta em formação, Riobaldo, acrescidas à canção original ouvida da voz de Siruiz quando esta já parecia querer se esvair de sua memória. Versos esses, aliás, ainda quase de todo deixados de lado pela crítica literária, todavia decisivos para a compreensão das diversas metamorfoses sofridas pelo herói.

De baldo jagunço Tatarana, lagarta-de-fogo, Riobaldo torna-se chefe Urutu Branco e, após combater o Hermógenes e sofrer a principal perda de sua vida, enfrentando "abismos inventados que dão reais calafrios" ${ }^{101}$, neblinado, abdica da travessia errante como jagunço em nome de uma outra travessia, agora como narrador. Convertido num guerreiro aposentado, fazendeiro e barranqueiro de rio, resolve contar sua história de vida para um transeunte, um viator, o calado interlocutor do romance apresentando-nos uma saga que se entrelaça e se emaranha com os versos e as canções por ele próprio compostos.

\footnotetext{
100 “Conheces o país onde florescem os limoeiros./ Em meio à folhagem escura ardem os pomos de ouro,/ Uma brisa suave sopra no céu azul,/ E o mirto e o louro em silêncio crescem?/ Não o conheces? Pois lá, para lá,/ Quisera contigo, meu bem amado, ir!!// Conheces a casa, cujo teto repousa sobre colunas,/ E onde brilham o salão e o aposento,/ E marmóreas estátuas se erguem e me fitam:/ 'Que te fizeram, minha pobre criança?'/ Não a conheces?/ Pois lá, para lá,/ Quisera contigo, meu protetor, ir!// Conheces a montanha e suas veredas enevoadas,/ Onde a mula entre neblinas seu caminho procura,/ Nas cavernas habita a velha cria do dragão,/ Onde a rocha se precipita, e sobre ela a torrente:/ Não a conheces?/ Pois para lá, para lá,/ Leva nosso caminho!, ó pai, sigamos pois tu e eu!" (tradução de Nicolino Simone Neto)

${ }^{101}$ RÓNAI, Paulo, in: op. cit. (2001: 18)
} 
Por fim, faz-se importante salientar que há, em Guimarães Rosa, uma espécie de nostalgia do nome, uma obstinada procura pela "palavra autêntica", pela espiralada busca do pequeno no ainda menor, palavra edênica que se encontra no princípio mítico da nomeação, Verbo dos Evangelhos, canto das Musas - em que, ao som, corresponde a imagem por esse sugerida - e que se assemelha ao conceito de linguagem para o pensamento mitopoético, nostalgia e procura essas das quais não poderemos abrir mão de, neste trabalho de pesquisa, com o autor compartilhar, na tentativa de esclarecer os enigmas da canção de Siruiz.

Se "no princípio era o Verbo", como anuncia o Evangelho de João, a palavra, para Rosa, aspira voltar a dizer o ser, a evocá-lo, a presentificá-lo, a eternizá-lo. Aparentemente é essa a chave para alcançar o divino, o demoníaco - o daemônico - e, como pontuou Heidegger, quando afirmou que "a palavra não diz mais o ser", para garantir a humanidade do homem, reencontrado com seu princípio. E é essa a chave que perseguiremos neste estudo, afinal, como concluiu Riobaldo, nas linhas finais do Grande sertão: veredas, $\boldsymbol{O}$

Diabo não há! (...) Existe é homem humano. Travessia." (GSV, p. 624)

Entretanto, para não cairmos na armadilha de embarcarmos numa leitura de concepção demasiado dialético-materialista ou "jovem hegeliana” das buscas de Riobaldo e do desfecho de Grande sertão: veredas, merecem atenção as palavras e considerações de Marcus Mazzari a respeito do "porquê do mal do mundo" e das "figurações do 'mal' e do "maligno""102 no grande sertão de Rosa:

Não seria de supor que Riobaldo - e com ele o próprio autor de Grande sertão: veredas compartilhasse da concepção filosófica, constituída na chamada "esquerda hegeliana", segundo a qual a ideia de Deus não significa outra coisa senão a projeção antropomorfizada da essência da espécie humana: Homo homini Deus est [O homem é o Deus do homem], como diz a célebre fórmula de Ludwig Feuerbach, a cujo pensamento o suíço Gottfried Keller levanta um monumento no último livro do seu romance $O$ verde Henrique. No entanto, Riobaldo talvez não tivesse muito a objetar quanto ao reverso possível daquela concepção, isto é, que também o diabo não representa outra coisa senão a catalisação personificada da maldade humana ou, indo mais além, dos males que se observam no mundo e se atribuem às esferas física, metafísica e moral. - Satanas sum et nihil humani a me alienum puto $^{103}$, já dissera, aliás, o diabo de Dostoiévski a Ivan Karamázov, sugerindo a substância humana que o constitui. (2010: 30$)$

Na mitopoética poesia hesiódica, o canto é a mais elevada expressão da palavra mítico criadora; em Grande Sertão: Veredas, a canção de Siruiz, juntando e tentando harmonizar armas e letras, épico e lírico, guerra e amor, masculino e feminino, físico e metafísico, bem e mal, e transformando o menino Baldo em

\footnotetext{
102 MAZZARI, Marcus V. in: op. cit. (2010: 27-41).

103 "Satanas sou, e nada do que é humano me é estranho.". Essa expressão latina que, segundo Mazzari é uma variação "satânica" da célebre sentença de Terêncio ["Sou humano, e nada do que é humano me é estranho."], que por sua vez remonta ao comediógrafo Menandro, encontrase no livro XI, capítulo 9 ("O diabo. O pesadelo de Ivan Fiódorovtch”), da obra Os irmãos Karamázov, de Dostoiévski.
} 
jagunço e o jagunço em aedo, poeta e cantor, prediz e insere, solve et coagula, temas que se gravam misteriosamente na memória do hamletiano Riobaldo e que o acompanharão por toda a vida: sua vocação para as armas - e para as letras -, sua busca por Deus e pelo diabo, e seu amor pela Moça Virgem, o Jagunço Diadorim - donzela guerreira mascarada que arrasta o letrado jagunço apaixonado para a guerra, mas não apenas como um sertanejo cavaleiro romanesco e, sim, como bem viu Lukács, citado por Arrigucci Jr. (1994), como um herói problemático e demoníaco, um "homem desterrado de sua verdadeira pátria, errante numa travessia solitária, sem retorno possível - homem moderno, descentrado e sem volta a uma verdadeira casa, que já não pode existir.” (1994: 29) 


\section{PALAVRAS ROMPENDO RUMOS}

O que eu vi, sempre, é que toda ação principia mesmo é por uma palavra pensada. Palavra pegante, dada ou guardada, que vai rompendo rumo.

(Grande sertão; veredas, Guimarães Rosa) ${ }^{104}$

A pouco mais da metade da misteriosa e grosso misturada travessia a que os leitores de Grande sertão: veredas são convidados e desafiados pelo seu autor Guimarães Rosa, quando já vai bem adiantada a narração, deparam, esses mesmos leitores, com o aposentado jagunço Riobaldo, agora convertido em fazendeiro e barranqueiro de rio, assentado numa boa cadeira de espreguiçar, a advertir, num monólogo recitado, seu interlocutor forasteiro a respeito das artimanhas e meneios de sua narrativa: Não esperdiço palavras. Macaco meu veste roupa. O senhor pense, o senhor ache. (GSV, p. 325)

Essa advertência do narrador-protagonista da obra a um interlocutor-ouvinte com quem, facilmente, os leitores podem se confundir, ouvinte esse que permanece invisível e calado ${ }^{105}$ do princípio ao fim do Grande sertão: veredas - ou do fim ao princípio, numa narrativa pretérita feita pelo fazendeiro Riobaldo, ex-jagunço, a um letrado e atento visitante que só se percebe pelas apóstrofes do narrador"106, num universo em que "o interior e o exterior já não podem ser separados" -, bem poderia ter saído da boca do próprio autor do romance ao se dirigir a todos os que se propõem à labiríntica jornada que é a leitura de sua obra: rio caudaloso de infinitos meandros em que cada remanso é também conselho de necessária cautela, promessa de redemoinho.

E Riobaldo prossegue, no mesmo entrecho de prosa, antes e depois, ardiloso, reticente, a tratar de sua própria narrativa, de sua estória e história, contando da fronteiriça chegada, in medias res, à Vila do Urubu:

Ah, meu senhor, mas o que eu acho é que o senhor já sabe mesmo tudo-que tudo lhe fiei. Aqui eu podia pôr ponto. Para tirar o final. Para conhecer o resto que falta, o que lhe basta, que menos mais, e pôr atenção no que contei, remexer vivo o que vim dizendo. Porque não narrei nada à-toa: só apontação principal, ao que crer posso. (...) O senhor ponha enredo. (...) Tenho saquinho de relíquias. Sou um homem ignorante. Gosto de ser. Não é só no escuro que a gente percebe a luzinha dividida? Eu quero ver essas águas a lume da lua. (GSV, p. 325)

Assim como Riobaldo afirma a seu interlocutor-forasteiro ter um metafórico "saquinho de relíquias", faz-se imprescindível, aos leitores, crer, seguindo seu próprio conselho, na necessidade de se pôr tento

\footnotetext{
${ }^{104}$ Grande sertão: veredas. 19ª ed. Rio de Janeiro: Nova Fronteira, 2001, p. 144.

105 Aqui vale lembrar que "calado", além de significar "aquele que não emite som", "quieto", também designa a profundidade em que se encontra o ponto mais baixo da quilha de uma embarcação, ou a distância entre a superfície da água em que a embarcação flutua e a face inferior de sua quilha, ou seja, mesmo que o interlocutor de Riobaldo não emita som, num romance que dá voz apenas ao seu narrador, é da profundidade do sugerido diálogo transmutado em monólogo que brota o todo da narrativa e da própria travessia de Riobaldo.

106 Como denota Paulo Rónai em seu “Três motivos em Grande Sertão: Veredas”, publicado pela primeira vez em 1956, em prólogo à primeira edição do Grande sertão: veredas, e republicado no prólogo à $11^{a}$ edição, de 2001, que serve de referência a este estudo.
} 
naquilo que ele conta, nas minúcias, no pequeno e no ainda menor, no que não se esperdiça, e no que é dele, apenas dele e de seu simbólico saquinho de relíquias, memórias e reflexões de onde fluem as palavras, a musicalidade e o silêncio de toda a narrativa, estória em que não há ponto sem nó ou "macaquices", em que nada é à toa e no qual, em tudo, que menos mais, precisam os leitores acreditar, mirar e ver, para pôr lastro à travessia, para não ficarem à deriva, baldeando entre uma e outra parte do rio da história, da estória, marginais ao que de fato importa e ao que merece entendimento. Ou para não sucumbir ao canto das sereias.

A decifração é uma obsessão para o narrador de Grande sertão: veredas. Eu sei que isso que estou dizendo é dificultoso, muito entrançado (GSV, p. 116) - afirma Riobaldo, numa aparente hermética e marota modéstia, ao seu interlocutor em outro momento da narrativa:

\begin{abstract}
Mas o senhor vai avante. Invejo é a instrução que o senhor tem. Eu queria decifrar as coisas que são importantes. E estou contando não é uma vida de sertanejo, seja se for jagunço, mas a matéria vertente. Queria entender do medo e da coragem, e da gã que empurra a gente para fazer tantos atos, dar corpo ao suceder. $O$ que induz a gente para más ações estranhas é que a gente está pertinho do que é nosso, por direito, e não sabe, não sabe, não sabe! (GSV, p. 116)
\end{abstract}

É na caudalosa fala de Riobaldo, curso de contínua pensante e intuitiva oralidade, e no seu monólogo com o forasteiro ouvinte, matéria vertente, que se encontra a única fonte da qual brota, jorra e flui todo o enredo e a inventividade criativa da narração desse enredo, desse "jorro de imaginação criadora na linguagem, na composição, no enredo, na psicologia", dessa "navegação no mar alto", como adjetivou Antonio Candido a literatura de Grande sertão: veredas, em seu "O homem dos avessos", literatura essa em que "há de tudo para quem souber ler, e nela tudo é forte, belo, impecavelmente realizado. Cada um poderá abordá-la a seu gosto, conforme o seu ofício, mas em cada aspecto aparecerá o traço fundamental do autor: a absoluta confiança na liberdade de inventar." (1991: 294).

E Candido, ainda nesse mesmo ensaio, faz uma importante advertência ao leitor-navegador que resolver se aventurar pelas trilhas, desertos, rios e veredas do Grande sertão rosiano:

Cautela, todavia. Premido pela curiosidade o mapa se desarticula e foge. Aqui, um vazio; ali, uma impossível combinação de lugares, mais longe uma rota misteriosa, nomes irreais. E certos pontos decisivos só parecem existir como invenções. Começamos então a sentir que a flora e a topografia obedecem frequentemente a necessidades da composição; que o deserto é sobretudo projeção da alma, e as galas vegetais simbolizam traços afetivos. Aos poucos vemos surgir um universo fictício, à medida que a realidade geográfica é recoberta pela natureza convencional.

Desdobremos bem o mapa. Como um largo couro de boi, o Norte de Minas se alastra, cortado no fio do lombo pelo São Francisco - acidente físico e realidade mágica, cursos d'água e deus fluvial, eixo do Sertão.” (1991: 296-297) 
Se, como aponta Candido, o deserto, em Grande sertão: veredas, é projeção da alma e as galas vegetais simbolizam traços afetivos, se certos pontos decisivos só parecem existir como invenções, se o rio São Francisco é acidente físico e realidade mágica, “curso d'água e deus fluvial do sertão", se certos nomes são “irreais” e, não menos, invenção, na nossa busca da decifração do enigma de Siruiz e sua canção, merece investigação a princípio, num mergulho na imaginação criadora de Rosa, o nome do protagonista Riobaldo que, ao que tudo indica, não existia antes da escritura do romance ${ }^{107}$. Para tanto, "desdobremos bem o mapa", mas não sem antes mergulharmos - como fez Hazin (1991), citada em nota - na importância dos nomes próprios, edênicos nomes, para a narrativa rosiana.

Muitos foram os críticos que já assinalaram a obsessão de Rosa pelo estilo e pelo nome exato para cada coisa, seu cuidado na escolha da melhor denominação possível para cada objeto, planta, animal e seu

107 Segundo Walnice Nogueira Galvão, em 22 de junho de 2013, em exposição tematizando a obra Grande sertão: veredas, de Guimarães Rosa, no ciclo de palestras "Romance de Formação: caminhos e descaminhos do herói”, Biblioteca Mário de Andrade - organizado por Marcus Vinícius Mazzari e Murilo Marcondes de Moura. Contudo, analisando o primeiro rascunho de GSV, HAZIN (1991: 117-121) vai mais fundo ao tratar da gênese do nome do protagonista:

O narrador é nomeado no texto [referindo-se ao rascunho] pela primeira vez à p. 18, na passagem em que Diadorim lhe revela ser filho de Joca Ramiro. Chama-se, então, Deodôlfo. Essa forma reaparece nas páginas 19, 20, 23, 25, 26 e 27, sempre alterado - a mão - para Riobaldo, mudança a posteriori da fixação definitiva do nome pelo autor (...) Há outro detalhe: a inserção, a princípio, é Riodôlfo, forma que irá aparecer - datilografada - somente à p. 52. Após redigir a página 52, vem grafado seis vezes (p. 31, 33, 40, 41 (2 vezes) e 44) o apelido Dôlfo, forma carinhosa com que Diadorim se dirigia ao amigo. Impossível saber se já se trata de apelido de Riodôlfo ou de Deodôlfo, ainda. O fato de Riodôlfo só aparecer após as seis grafias de Dôlfo, de forma alguma atesta que estas estejam ligadas ao primeiro vocativo do personagem. Prova disso é que Baldo aparece à pág. 60, antes mesmo do leitor tomar conhecimento do verdadeiro e definitivo nome do narrador da estória que está lendo: Riobaldo. "Professor Riobaldo" (p. 69).

Houve primeiramente alteração apenas na silaba inicial do nome: Deo modificou-se para Rio. A seguir, o restante foi modificado. Deodôlfo. Riodôlfo. Riobaldo. Assim, o segundo nome tem a ver com o primeiro, e o terceiro com o segundo, nada existindo, porém, em comum, entre o terceiro e o primeiro (...) Tenho para mim que a substituição de Deo por Rio é muito significativa. Deo, primeira escolha de Guimarães Rosa, foi grafado possivelmente para indicar oposição ao Diá que aparece em Diadorim. Essas alusões meramente silábicas, discretos prefixos, teriam a função de pôr em confronto, de início, dialeticamente, os opostos, os dois princípios, quase maniqueisticamente demarcados ao longo do texto de Grande sertão: veredas, sob suas formas clássicas: o Bem e o Mal, o Claro e o Escuro, o Ser e o NãoSer. Tal oposição, todavia, vai resolver-se, mais tarde, no final do livro, ao revelar-se que o nome verdadeiro de Diadorim é Deodorina: assim, é no personagem enigmático, carregado de hermafroditismo psicológico, naquele ser que funde em si mesmo o demoníaco e o angélico, que se dá a coincidentia oppositorum, a fusão de "diá" (do diabo) e de "deo" (do divino).

À medida que o texto flui, a imagem do rio vai aos poucos adquirindo dimensão mítica. "Nesse plano" - escreve Cavalcanti Proença - "o rio é figura de primeira grandeza. Há mesmo, no desenrolar da estória, uma indistinção em que ele e o herói se confundem, superpondo-se, ou correndo paralelos" (1959: 178). Todavia, Rosa mantém, ainda, a segunda metade do nome: Riodôlfo, nome que à semelhança de Riobaldo, "evoca, em primeiro lugar, por sua sonoridade, os nomes dos brilhantes guerreiros germânicos" (Machado, 2003: 60).

Acredito que Guimarães Rosa não alimentasse nenhuma intenção secreta de "significância" para dôlfo. Atraia-o apenas a sonoridade dissilábica, mesmo porque dôlfo nada significa. Do dicionário de nomes [referindo-se a Johnson, Charles \& Sleigh, Linwood, Names for boys and girls, p. 67], extraímos EDWIN, do anglo-saxão: ("ead" = prosperity e "wine" = friend), inserido numa lista do que comumente se chama "Ed-names". No mesmo verbete, vem citado EDWULF ou EDULPH (“prosperity-wolf”), provável deturpação de Adolphus. Ora, segundo a etimologia da palavra, Adolphus seria dividido em AD e OLPHUS, sendo o primeiro liado a "ead" (prosperidade) e o segundo a "Wolf" (lobo). Dôlfo seria um aproveitamento dessa terminação, sem levar em conta o significado etimológico.

Não se deve esquecer de que ao grafar o nome Riobaldo, o autor está, também, utilizando desinência muito comum nos nomes germânicos: $\underline{\text { bald. }}$.

No alto alemão medieval, BALD - como palavra - era sinônimo de KÜHN, TAPFER, as quais significam, respectivamente, "audaz - o que pode" e "corajoso, valente". Em alemão moderno, é advérbio e significa "em breve, logo"; "quase".

Tanto em sua forma arcaica, quanto na atual, os significados podem aplicar-se ao personagem de Grande sertão: veredas: à sua coragem e à própria frustração existencial do personagem (se optarmos pela significação "quase") - Riobaldo quase viveu: passou por perto de tudo, sem saber. O "quase" sugere, ainda, estado de dúvida, e é em tal estado que o personagem se encontra mergulhado do início ao fim da narrativa.

Profundo conhecedor da língua alemã, Guimarães Rosa naturalmente não desconhecia esses significados. Essa hipótese reforça a ideia (...) de que BALDO teria sido, na realidade, um dos estágios do nome do personagem, grafado a partir da lista do Arquivo. 
meticuloso engenho na seleção e criação dos nomes próprios dos personagens. Ana Maria Machado, em seu Recado do nome ${ }^{108}$, sistematizando outros tantos pareceres críticos a respeito, parece concordar com isso, todavia endossando o caráter de "invenção" denotado por Candido, salienta:

Mas o mais importante nesse processo, principalmente quando se trata de nomes de pessoas - que teoricamente deveriam ter um único nome possível -, parece ser justamente o contrário de qualquer exatidão. Os Nomes são escolhidos tendo em vista sua polissemia, não sua univocidade. O próprio autor nega que sua narrativa seja "rol de nomes" (GSV 287) e não quer se gabar de "retentiva cabedora, nome por nome" (GSV 424). Pelo contrário, afirma que os Nomes importam porque "ficaram com assento de sustos e sofrimentos" (GSV 287), captando o dinâmico e o transformável”. (MACHADO, 2003: 49)

Comparando a obra de Guimarães Rosa à de Proust, Machado afirma que o nome próprio, para Rosa, é uma "palavra poética", um "signo espesso e rico que escapa sempre aos limites de cada sintagma, enviando sempre ao conjunto do texto, e mesmo para além do texto". E a estudiosa complementa:

O Nome [nas narrativas rosianas] é um signo polissêmico e hipersêmico que oferece várias camadas de semas e cuja leitura varia à medida que a narrativa se desenvolve e se desenrola. Não há mais um sentido único de leitura, mas uma decifração e recriação permanente, feita de dedução e de intuição, de sensibilidade e de exploração das diferentes possibilidades de atualização daquilo que é dito potencialmente pelo Nome (...). (2003: 44)

Portanto, e concordando com Machado, os nomes próprios, em Rosa, nada têm a ver com simplificação ou reificação, pelo contrário, são instáveis, assinalam e assimilam mudanças e, além de admitirem leituras múltiplas, atuam como múltiplos, inclusive nos mesmos personagens. "Muito mais do que simplesmente descritivos ou alegóricos, eles são evocativos, carregados de significados que vão permanentemente mudando, como se modifica muitas vezes o significante do Nome à medida que a narrativa se desenrola." (2003: 50).

Em Grande sertão: veredas, os protagonistas - e mesmo alguns importantes personagens secundários - quase que invariavelmente têm diversos nomes que se mesclam, se amalgamam, se trocam, se substituem, se cruzam e se completam no transcorrer da narrativa. O nome não atribui ao personagem uma característica marcante que alegoricamente o representa e o acompanha em todas as situações por ele vivenciadas, como acontece, por exemplo, nas epopeias clássicas ou nas novelas de cavalaria ${ }^{109}$, mas, pelo contrário, o nome de um mesmo personagem vai recebendo, em cada novo momento, um significado novo e, frequentemente, até

108 MACHADO, Ana Maria. Recado do nome - Leitura de Guimarães Rosa à luz do nome de seus personagens. Rio de Janeiro: Nova Fronteira, 2003. A numeração das páginas das transcrições de Machado diz respeito ao Grande sertão; veredas, em sua $2^{\mathrm{a}}$ edição, publicado pela editora José Olympio, 1958.

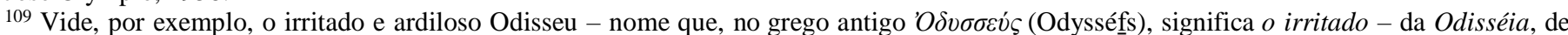
Homero, ou o entristecido e melancólico Tristão, da novela de cavalaria Tristão e Isolda, de autoria desconhecida. 
mesmo um significante novo, muitas vezes associados a aspectos sensoriais, afetivos ou culturais vinculados ao momento e à contingência da narrativa, ao desenrolar da ação.

Em entrevista a Pedro Xisto, revelou Guimarães Rosa, certa vez, “que certos nomes próprios decidiam dos respectivos personagens e que certas estórias foram grandemente alteradas sob essa onomástica ação de presença". ${ }^{110}$ O próprio Riobaldo afirma: Que é que é um nome? Nome não dá: nome recebe. (GSV, p. 172)

Machado chama a atenção para os caminhos propostos por Rosa, a partir dos nomes de seus personagens, no decifrar de suas narrativas, comparando-os com os pilares do que há de mais expressivo na tradição literária:

Quando Fausto, a Divina Comédia, a teologia ou os livros sagrados hindus impregnam sua narrativa, por exemplo, os textos apresentam uma profusa disseminação de elementos significativos orientando a leitura. Grande parte desses elementos é constituída pelos nomes próprios e uma leitura atenta de Guimarães Rosa não pode dispensar sua análise. (MACHADO, 2003: 46)

Nomes existentes, comuns, que, como aponta Machado, sob um manto de nova significação, parecem inventados e nomes inventados que, de tão fiéis aos modelos do idioma, dão a impressão ao leitor de que, mesmo que ele não os conheça, com certeza devem e podem existir. Nomes que, através das correspondências sensoriais, simbólicas, metafóricas, metonímicas e sinestésicas, enquanto significantes, quer por condensação, quer por deslocamento, dilatam-se e remetem a outros significantes num labiríntico e vertiginoso jogo de espelhos, e nomes já existentes na língua cotidiana, mas que, carregados de alusões a outros textos, religiosos, mitológicos, filosóficos, literários, históricos, reinventam-se de forma mitopoética, mascarando e recriando a própria tradição, a qual Rosa - autor que falava e lia dezenove línguas, dentre elas o japonês, o árabe, o persa e o hindi, além das principais línguas ocidentais, cujas reminiscências o poliglota, como afirma Paulo Rónai, nem sempre soube ou quis reprimir ${ }^{111}$ - conhecia muito bem e em meio a qual vai tratando de ir mostrando os caminhos a serem decifrados por intermédio do próprio texto. Estes são os aspectos do "ato de nomear" a que os leitores devem estar atentos no processo de compreensão e de decifração, de navegação, nos meandros sertanejos da obra rosiana.

Pois bem, se como afirma Riobaldo, Só quando se tem rio fundo, ou cava de buraco, é que a gente por riba põe ponte (GSV, p. 479), já cavamos o nosso buraco, deparamos com o nosso rio. Sendo assim, palavras rompendo rumos em busca dos caminhos e do decifrar, voltemos a pouco e pouco à canção de Siruiz, que é também um canto das águas, através do mapa a se desdobrar "feito um largo couro de boi", proposto por Candido, e ao seu "Norte de Minas cortado no fio do lombo pelo São Francisco - acidente físico e

110 “À busca da Poesia”, in: Guimarães Rosa em Três Dimensões. Comissão Estadual de Literatura, São Paulo, 1970.

${ }^{111}$ RÓNAI, Paulo. In: "Três motivos em Grande sertão: veredas", prólogo ao Grande sertão: veredas (ROSA, 2004: 15-20). 
realidade mágica, curso d'agua e deus fluvial, eixo do Sertão". E voltemo-nos ao protagonista-narrador de Grande sertão: veredas, e, em meio a tantos outros nomes que foi herdando e conquistando durante a travessia $^{112}$, à gênese de seu polissêmico e hamletiano nome próprio primevo, Riobaldo, que como trataremos, em breve, muito tem a nos dizer sobre o enigma da canção de Siruiz e sua fluida relação com o destino e a formação do herói sertanejo.

O meu Urucúia vem, claro, entre escuros. Vem cair no São Francisco, rio capital. O São Francisco partiu minha vida em duas partes. (GSV, p. 325). Assim se refere Riobaldo, na glosa do meio do romance, aos rios Urucuia e São Francisco, de importância capital não apenas para a estória do Grande sertão: veredas, mas também para a travessia do próprio protagonista, para a inventiva construção de seu nome e para a decifração da canção de Siruiz. E não é apenas nesse momento da narrativa que o narrador sertanejo demonstra sua profunda afinidade com os rios: $O$ tanto assim, que até um corguinho que defrontei-um riachinho à-toa de branquinho - olhou para mim e me disse: - Não... - e eu tive que obedecer a ele. Era para eu não ir mais para diante. O riachinho me tomava a benção. Apeei. (GSV, p. 304), afirma o solitário jagunço, ante o vazio do mundo a sua frente, atravessando um ribeirão verde, um vau de gado, em meio a umbuzeiros e ingazeiros debruçados, à caça de gente diferente e constatando, culpado e entristecido - sem saber de que ou dos porquês disso -, que quanto mais andava querendo pessoas, parece que tanto mais entrava no sozinho do vago. Como as veredas trazem vida ao sertão e guiam os passos dos boiadeiros e da boiada, na personificação do "riachinho", percebemos o quanto os rios e as águas norteiam e enveredam a vida e a saga sertaneja do nome Riobaldo e daquele que the nomeou.

De imediato, o substantivo próprio Riobaldo - como aponta Hazin $(1991)^{113}$, nome escolhido de uma lista para evocar o narrador do romance - pressupõe, ao menos, o partir-se em duas partes: Rio e -baldo. E, para a tentativa de construção da ponte, ou para o início do mergulho especulativo no rio fundo do Grande sertão, seguindo as pistas fornecidas primeiramente por Antonio Candido, já aqui denotadas, foquemos a primeira dessas partes, o "Rio", e a relação do autor Guimarães Rosa com a inquietante imagem do rio, para, após, voltarmos ao Grande sertão: veredas.

Paulo Rónai, em "Rondando os segredos de Guimarães Rosa", alerta-nos para o fato de que, na obra rosiana, "teatro em que não há separação entre palco e plateia", o autor e as personagens nunca são completamente distintos: "Usam a mesma língua, a ponto que volta e meia aquele passe a palavra a estas sem que se note qualquer mudança de plano. Tal praxe não somente não conduz à limitação do registro das

\footnotetext{
112 Aliás, como os rios São Francisco ou Urucuia que, na travessia rumo ao mar, vão herdando suas águas de afluentes cujas origens estão em muitas veredas e em inumeráveis olhos d'água.

113 HAZIN (1991) se refere à lista dos nomes do protagonista de GSV até chegar ao definitivo Riobaldo levantados dos primeiros rascunhos, datados de julho de 1954.
} 
notações, mas, por um milagre de arte, confere-lhe amplitude raras vezes atingida em qualquer literatura" (2001: 18). Concordando com isso, denotamos a merecida investigação sobre a relação de Rosa com esse "rio" que, além de nomear o protagonista de Grande sertão: veredas, é, tantas vezes, pelo narrador, retomado ao rememorar e tentar trazer sentido à sua travessia.

Guimarães Rosa, em depoimento a Günter Lorenz, no "Diálogo com Guimarães Rosa"114, assim trata da sua relação com os rios e, em particular, com o São Francisco:

(...) gostaria de ser um crocodilo vivendo no rio São Francisco. O crocodilo vem ao mundo como um magister da metafísica, pois para ele cada rio é um oceano, um mar de sabedoria, mesmo que chegue a ter cem anos de idade. Gostaria de ser um crocodilo, porque amo os grandes rios, pois são profundos como a alma do homem. Na superfície são muito vivazes e claros, mas nas profundezas são tranquilos e escuros como os sofrimentos dos homens. Amo ainda uma coisa de nossos grandes rios: sua eternidade. Sim, rio é uma palavra mágica para conjugar eternidade.” (LORENZ, 1991:72)

A simbólica imagem do rio para o "magister da metafísica" que gostaria de ser um crocodilo, Guimarães Rosa, “conjuga eternidade”, une, junta, mistura, enuncia a eternidade em todas as suas flexões literais e metafóricas, físicas e metafísicas. Compreendendo-se o encantamento do autor pela linguagem e pelos rios que "na superfície são muito vivazes e claros, mas nas profundezas são tranquilos e escuros como os sofrimentos dos homens", há de se desconfiar de um nome inventivamente tão sugestivo e sedutor como Riobaldo. Mergulhemos nesta desconfiança.

Roberto Schwarz, em "Grande sertão e Dr. Faustus”115, afirma que o rio São Francisco é, em Grande sertão: veredas, a "espinha dorsal cujos braços permeiam tudo no romance" (1965: 36), uma espécie de "eixo do sertão" - fazendo alusão aos termos usados por Candido, em "O homem dos avessos", com quem concorda - e lembra que foi às margens desse rio, com a fascinação infantil por Diadorim - "cordura em roupa de homem", “doçura entre jagunços, neblina de Riobaldo, máscara e engano, rosto do diabo"-, que o autor principiou a compor - ainda antes da noite de maio e do encontro com a orvalhada canção de Siruiz - a travessia do herói Riobaldo até a "transmissão da vendeta de honra" que leva o personagem a procurar forças, num pacto diabólico, para vingar o assassinato de Joca Ramiro, pai de Diadorim.

E Schwarz acrescenta: "Diadorim flutua pelo mistério de suas predileções pouco jagunças - pássaro, flor e limpeza - e traz ambiguidade ao sertão. É só o avançar do romance que nos dará seu retrato claro, e entanto desde a primeira entrada em cena a sua presença é total...” (1965: 33).

${ }^{114}$ LORENZ, Günter. "Diálogo com Guimarães Rosa”. In: COUTINHO, Eduardo F. (org.) Guimarães Rosa. Rio de Janeiro: Civilização Brasileira, 1991.

${ }^{115}$ SCHWARZ, Roberto. “Grande Sertão e Dr. Faustus”, in: A sereia e o desconfiado. Rio de Janeiro, Civilização brasileira, 1965. 
Se o rio é, para Candido, o "eixo do sertão", nas palavras de Schwarz, "Diadorim não é o diabo, mas a espetadela do destino que põe Riobaldo fora dos eixos, abaixo, acima e além do sertão". E, sobre a onipresente imagem do rio, Schwarz conclui: "Na página final do livro (...) o rio São Francisco emerge da fala ambígua [de Riobaldo] transformado em pênis gigantesco ${ }^{116}$, emblema de continuidade e paixão. Existe é homem humano. Travessia." (1965: 36)

Com a morte de Diadorim-Deodorina, com a revelação, pelo corpo nu, de sua feminilidade, Riobaldo se torna o chefe respeitado de jagunços que, feito onipotente rio em tororoma, limpou o sertão da jagunçagem.

Heloisa Vilhena de Araújo, em $O$ roteiro de Deus ${ }^{117}$, também trata da transferência da paixão de Rosa pelos rios, em particular pelo São Francisco, para a quase obsessão de Riobaldo pela imagem do rio em Grande sertão: veredas. Citando Viggiano ${ }^{118}$ e seu estudo Itinerário de Riobaldo Tatarana, aponta que o rio do Chico é mencionado mais de cinquenta vezes no texto e é cruzado, num movimento de vaivém, quatro vezes por Riobaldo. Notemos os levantamentos do próprio Viggiano a respeito do que diz Araújo:

Só o São Francisco é citado mais de cinquenta vezes em Grande sertão; veredas. Além dele, ainda temos, uns, variadas vezes, outros de passagem, os rios de alguma importância: Urucuia, Preto, Pardo, Cochá, Paracatu, de Janeiro, Acari, São Domingos, Borá, Araçuaí, Verde Grande, Verde Pequeno, Canabrava, do Sono, Soninho, Água Branca, Pacu, das Velhas, Jequitaí, Cansanção, José Preto, Carinhanha, São Marcos e Abaeté. (2007: 22)

E o mesmo Viggiano retoma a importância crucial dos rios no roteiro de idas e vindas no sertão empreendido por Riobaldo:

[...] é aos rios que o roteiro de "Tatarana" está sempre ligado. O São Francisco é o maior de todos, ponto de referência. O Paracatu e o das Velhas são rios importantes na vida do jagunço. Ao Urucuia "onde todo boi berra", ele está preso pelo amor. "Confusa é a vida da gente. Como esse meu Urucuia vai se levar no mar." Rio meu, de amor, é o Urucuia"119. (2007: 22)

Além disso, Vilhena também trata da importância essencial da travessia do rio São Francisco para a própria travessia de Riobaldo: “(...) o encontro de Riobaldo com o Menino e a travessia do rio São Francisco em 'bamba canoa' (p. 107) prefiguram, imperfeitamente, as três futuras travessias do mesmo rio, que fará

\footnotetext{
${ }^{116}$ SCHWARZ, Roberto, in: op. cit., chega a essa conclusão a partir do trecho do final do GSV que compara o rio São Francisco, que de tão grande se comparece, a um pau grosso, em pé, enorme... (GSV, p. 624).

${ }^{117}$ ARAUJO, Heloísa Vilhena de. O roteiro de Deus: dois estudos sobre Guimarães Rosa. São Paulo: Editora Mandarim, 1996.

${ }^{118}$ VIGGIANO, Alan, Itinerário de Riobaldo Tatarana - Geografia e Toponímia em Grande Sertão: Veredas, $4^{\mathrm{a}}$ ed., Belo Horizonte: Editora Crisálida, 2007.

119 Aqui, Viggiano trata da identificação específica de Riobaldo com o rio Urucuia, confuso rio seu, de amor, que, em verdade, baldo, não desaguará no mar, mas, sim, e antes, desaguará no São Francisco. E é só pelos meandros, caminhos tortuosos, deste último, que, misturado, poderá ansiar pelo mar.
} 
acompanhado ou não de Diadorim, e que são, no fundo, a travessia de sua vida de jagunço até chegar à outra margem, isto é, à outra vida, de fazendeiro pacato.” (ARAÚJO, 1996: 39)

E, navegando devagar os meandros da literatura rosiana, em Grande sertão: veredas, Araújo interpreta a fixação de Rosa pelos "rios", "palavra mágica para conjugar eternidade”, traçando um paralelo com outra travessia, a da Divina Comédia, de Dante Alighieri:

A viagem de Riobaldo cruzando repetidamente o São Francisco, uma primeira vez com o Menino, prefiguração das outras, posteriores, algumas com o mesmo Menino, é, assim, uma viagem pela eternidade, pelo Além, pelo Inferno, pelo Purgatório e pelo Paraíso. Como em Dante, Riobaldo viaja duplamente, literal e alegoricamente.

A viagem de Dante faz-se num movimento espiral descendente à esquerda - pelo Inferno - e ascendente à direita, pela montanha do Purgatório, em torno de uma mesma linha reta vertical que passa por Jerusalém no hemisfério norte, pelo fundo do Inferno, pelo centro da montanha do Purgatório no hemisfério sul, atingindo, no seu cimo, o Paraíso terrestre. Este, o jardim do Éden, está exatamente na mesma posição que o fundo do Inferno e Jerusalém.

A viagem de Riobaldo, da mesma forma, descreve um movimento irregular, de vaivém, em volta de uma linha, desta vez um eixo horizontal, representado pelo rio São Francisco. O seu início, com Diadorim já adulto, se dá a partir da margem do Rio das Velhas, barra do córrego do Batistério, localizado por Viggiano no município de Várzea da Palma, pouco abaixo da cidade de Pirapora, à margem direita do São Francisco. Seu fim tem lugar quando morre Diadorim, no povoado do Paredão, igualmente localizado por Viggiano no distrito de Buritizeiro, à beira do rio do Sono, quase em sua confluência com o Paracatu, à margem esquerda do São Francisco. Está assim, de certa maneira, face a face com o córrego do Batistério, com o ponto de início, só que do outro lado do grande rio - em latitudes diferentes, mas na mesma longitude. O São Francisco separa o começo do fim.

Assim, o eixo vertical que orienta a viagem de Dante pela eternidade parece ter seu reflexo no eixo horizontal, o rio São Francisco, que baliza o roteiro de Riobaldo igualmente pelo Além: "O São Francisco partiu minha vida em duas partes". (1996: 39-40)

Outra pesquisadora que atrela a imagem do rio, do nome Riobaldo, à influência da obra dantesca em Rosa, também endossando o "movimento irregular, de vaivém” do jagunço, é Rosenfield, em seu Grande sertão veredas - Roteiro de Leitura, afirma:

O nome Riobaldo permite ser decomposto em dois elementos - o que designa o fluxo e a mutação constante da água (rio) e o elemento -baldo que evoca a palavra dantesca "baldanza", traduzível, segundo a sugestão do próprio J. G. Rosa, como "saborear preguiçoso". No nome está, assim, secretamente inscrita a disposição íntima do caráter do personagem que tende a abandonar-se passivamente às experiências da vida. Ele chama-se a si mesmo de "seguidor" e de homem "sem convicção nenhuma" que vai longe na observação de hábitos alheios, sentindo-se constantemente ameaçado pela deriva - deriva do sentir, do imaginar, do inventar. (1992: 88-89)

Saindo da inspiração clássica e rumando em direção à modernidade, podemos encarar outra face da obra e do autor de Grande sertão: veredas, a moderna, denotando na imagem do rio e na obsessão de Rosa por ela - assim como no construído nomear de Riobaldo - um eco e uma resposta ao caráter aquoso, líquido, 
que as coisas estavam tomando em seu contexto de criação e nos sertanejos cenários que lhe serviam de inspiração. No Grande sertão rosiano, como apontou João Batista Santiago Sobrinho, em “A percepção Viggiana e líquida do sertão" ${ }^{120}$, em mais uma das muitas e reversíveis oposições desse mundo de avessos, figurado e misturado nos elementos água e terra do sertão, teríamos o confronto entre o moderno (líquido) e o arcaico (sólido). E, para ilustrar sua tese a respeito do moderno tomando conta e mudando o mapa do sertão, Sobrinho cita Zygmunt Bauman e sua Modernidade Líquida:

(...) os líquidos, diferentemente dos sólidos, não mantêm sua forma com facilidade. Os fluidos, por assim dizer, não fixam o espaço, nem prendem o tempo. Enquanto que os sólidos têm dimensões espaciais claras, mas neutralizam o impacto e, portanto, diminuem a significação do tempo (resistem efetivamente ao seu fluxo ou o tornam irrelevante), os fluidos não se atêm muito a qualquer forma e estão constantemente prontos (e propensos) a mudá-la: assim, para eles, o que conta é o tempo, mais do que o espaço que lhes toca ocupar; espaço que, afinal, preenche apenas "por um momento". Em certo sentido, os sólidos suprimem o tempo; para os líquidos, ao contrário, o tempo é o que importa. (BAUMAN, 2001: 8).

Nessa acepção, e fazendo ainda alusão aos estudos de Sobrinho, em Grande sertão: veredas, vemos que Joca Ramiro, o sal do chão, representante da terra e do velho sertão, do arcaico, não tem como comungar com as ambiguidades e ambivalências riobaldianas, do viver entre os mundos, do sólido e do líquido, do antigo e do moderno, do velho e do novo, e precisa, feito o sertão antigo, ficar e ser deixado para trás. Ao confrontar-se com a modernidade representada por Zé Bebelo, por exemplo, essa concepção arcaica do sertão, em Joca Ramiro, se confirma: $O$ senhor não é do sertão. Não é da terra...

Willi Bolle, em grandesertão.br ${ }^{121}$, também traça uma interessante relação entre o nome Riobaldo e sua relação com a imagem do rio, atrelando a essa imagem, alegoricamente, seu viés mais civilizatório, histórico e moderno:

Postado à margem do Rio São Francisco, que é o "grande caminho da civilização brasileira"122, o narrador-barranqueiro Riobaldo propõe uma leitura alegórica desse rio. A metáfora fluvial impregna a composição de Grande Sertão: Veredas na sua essência. Euclides, no seu livro sobre a Amazônia, falou do "ciclo vital" de um rio, como se fosse a biografia de um homem ${ }^{123}$; Guimarães Rosa avança na comparação no sentido de criar um autêntico narrador-rio. Se interpretarmos o baldo em Riobaldo como uma incorporação do núcleo alemão "baldowern" ("explorar"), chegamos à imagem do protagonista-narrador como explorador de um rio, que é alegoricamente o Rio da História. Esta interpretação, que

\footnotetext{
${ }^{120}$ In: Apresentação à $4^{\text {a }}$ edição de VIGGIANO, Alan. Itinerário de Riobaldo Tatarana - Geografia e Toponímia em Grande Sertão: Veredas, $4^{\text {a }}$ edição, Belo Horizonte: Editora Crisálida, 2007, p. 7-18.

${ }^{121}$ BOLLE, Willi. grandesertão.br: O romance de formação do Brasil. São Paulo: Duas Cidades; Ed. 34, 2004.

${ }^{122}$ Referência à citação de João Ribeiro, 1900, História do Brasil, apud. OS: 89.

${ }^{123}$ CUNHA, Euclides da. À margem da História. Org. por Rolando Morel Pinto. São Paulo: Cultrix, 1975.
} 
diverge da leitura costumeira do nome de Riobaldo ${ }^{124}$, mas vai ao encontro do significado etimológico de história (de historein = "investigar"), é sustentada por vários fatos do texto: 1. a identificação explícita do narrador com o elemento fluvial: "[...] penso como um rio tanto anda: que as árvores das beiradas mal nem vejo..." (GSV: 260); 2. a intenção de contar a "matéria vertente", ou seja, decifrar o "grande sertão" por meio das "veredas" que "sabem" dele (GSV: 79); 3. A significação alegórica da leitura dos cursos de água por Riobaldo, que na verdade é um comentador de discursos sobre o Brasil que o romance apresenta em forma de desmontagem e remontagem crítica. (2004: 77)

Mesmo discordando das interpretações demasiado simbólicas do nome do protagonista de Grande sertão: veredas, mesmo optando pelo viés alegórico ${ }^{125}$ para sua análise, merece nota o fato de que Bolle não desatrela esse nome da imagem do rio, tratando Riobaldo como um "narrador-rio".

Nesse vaivém circular em volta de uma linha, um eixo, representada pelo rio São Francisco, “que separa o começo do fim" da narrativa, nessa baldanza, nessa travessia de margem a margem do rio e da existência - da margem direita à margem esquerda, de Joca Ramiro a Zé Bebelo, do velho e do novo, do alegórico e do simbólico, do arcaico e do moderno, do físico e do metafísico, da estória e da história, daquele que por tanto procurar Deus acaba supostamente fazendo um pacto com o diabo, do amigo e do amante de Diadorim, do menino bastardo ao professor de Zé Bebelo, do professor ao remansado jagunço, do jagunço atirador Tatarana ao chefe de jagunços Urutu Branco, do chefe de jagunços ao pacato fazendeiro e barranqueiro de rio, do pacato fazendeiro ao narrador que adora especular ideias -, sem abrir mão da precavida, cuidadosa, análise de Wille Bolle, mas também atentos a outras possíveis formas de interpretação, partimos em busca de novas pistas para o mergulho mais aprofundado na segunda parte do nome Riobaldo, o termo -baldo.

Baldo, em seu sentido denotativo e usual, de dicionário, é um adjetivo que, como já fora aqui tratado, significa falho, desprovido de algo, carente, frustrado, mas não fica nisso. O verbo baldear, no particípio "baldo", significa transferir algo ou alguém de uma embarcação para outra, balançar, agitar, sacudir algo de um lado para o outro, lançar-se, passar-se de um para outro lugar.

Bolle, tentando romper com o que chama de "as exegeses convencionais", que, segundo o crítico, entendem o nome Rio-baldo como - apenas - o de um homem "frustrado"126 - ou, por compensação, de

\footnotetext{
${ }^{124}$ BOLLE se refere às interpretações de A. M. Machado, em Recado do nome (1976/1991), na esteira de C. Proença (1958: 40-42), que se atém à significação de baldo ("frustrado"), reafirmando Riobaldo "como o rio Urucúia [...] que nunca chega ao mar, frustrado em sua vida de jagunço", interpretações essas seguidas e endossadas também por outros tantos críticos e estudiosos.

${ }^{125}$ Acreditamos que o viés demasiado alegórico que Bolle atribui ao nome Riobaldo, tratando o personagem apenas como um "comentador de discursos sobre o Brasil que o romance apresenta em forma de desmontagem e remontagem crítica", pode empobrecer a leitura e a análise, por isso, mesmo respeitando as conclusões do especialista, optamos por não fechar em demasia a interpretação, respeitando seu potencial simbólico. ${ }^{126}$ PROENÇA, Cavalcanti, in Trilhas do Grande Sertão. Rio de Janeiro: José Olympio Editora, 1959, afirma que a morte de Diadorim justifica o sentido etimológico de "baldo" no nome do protagonista do romance: "Riobaldo, Rio-Baldo, não se realizou como jagunço" (p. 162). Hazin (1991) cita também Luiz Costa Lima, que concorda com Proença:

"RIOBALDO ex-jagunço: rio baldo, falho, infecundo. O nome cunhado para o único personagem no Grande sertão: veredas indica a impregnação simbólica do livro. E mais do que isso, indica a ambivalência que nele irá prevalecer. Já a palavra 'rio' é de per si um 'símbolo ambivalente'. Pois 'de um lado simboliza a fertilidade e a progressiva irrigação da terra; de outro, o transcurso irreversível e, em consequência, o abandono e o esquecimento" (LIMA, 1969: 71)
} 
alguém que atingiu "a plenitude" -, baseando-se na interpretação etimológica do termo "baldo", propõe uma leitura diferente:

A partir do verbo alemão baldowern (explorar) podemos remontar ao substantivo hebraico ba'al-davar, que designa "o dono das palavras e das coisas". Na Idade Média, "um eufemismo para o Diabo", a palavra migrou através do iídiche baldower (o referido, "o O") para o alemão, mais especificamente, para a linguagem dos marginais, sendo o Baldowerer "aquele que sonda o lugar e as oportunidades para um crime". No século XIX, o verbo baldowern passou para a linguagem coloquial no sentido de "explorar, auscultar, investigar" [...] Postado à margem do Rio São Francisco, que é o "grande rio da civilização brasileira", o narrador Riobaldo exerce o papel de um investigador dos discursos que falam da história do país, sobretudo daquilo que ela tem de oculto, demoníaco e dissimulado". (2004: 5)

Arroyo também desconfia das conjecturas - mesmo as mais fundamentadas - que associam em demasia o termo "baldo" ao suposto caráter de "frustrado", "inútil”, do personagem ${ }^{127}$ - ou apenas a isso -, atribuindo ao nome uma interpretação própria:

[...] a invenção do nome de Riobaldo não nos parece apenas ligada a uma extensão de inutilidade. João Guimarães Rosa mostra à saciedade a sua sutileza de criador em tais invenções. É oportuno lembrar o vocábulo valdevinos ou valdo, que tem origem em Balduíno, tipo de cavaleiro andante, do ciclo carolíngio, de grande popularidade em Portugal a ponto de seu nome passar a ser apelativo, como no Brasil igualmente. Por outro lado, valdio, valdeiro, valdo (que se perdeu), ou apenas este último vocábulo, poder-se-ia fundir com rio, rio+valdo = rio que se perdeu, como na lição de M. Cavalcanti Proença. Distinguem-se duas outras particularidades curiosas em torno do nome Riobaldo. Na novela El Cavallero Cifar há um personagem de nome Ribaldo que Menéndez y Pelayo considera "hasta ahora el único antecesor conocido de Sancho Panza", personagem, aliás, que representaria a invasão do realismo espanhol na ficção cavalheiresca. Ribaldo era "o avisado e sentencioso criado de Cifar, que segue a sua fortuna lealmente embora o considere desventurado e de poco recabdo". Mas, coincidentemente, o nome próprio Valdo é o do fundador de uma seita herética que existiu na Provença (França), no século XII. Pedro Valdo separou-se da Igreja com vários seguidores que se deram o nome de "pobres de Lyon": rejeitavam o culto dos santos, da missa, da confissão e de numerosos sacramentos. E em matéria de heresias Riobaldo nada fica a dever a Valdo. (1984: 95)

Teses, hipóteses, conjecturas e desconfianças levantadas, a interpretação dada por Consuelo Albergaria, em Bruxo da linguagem no Grande sertão ${ }^{128}$ - da qual Bolle provavelmente também discordaria e na qual, entretanto, nos apoiaremos, contudo de forma precavida, para dar a imediata sequência a nossos estudos -,

\footnotetext{
127 ARROYO, Leonardo, in A Cultura Popular em Grande Sertão: Veredas. Rio de Janeiro José Olympio Editora, 1984, também confronta Proença. Afirma Arroyo: "Para M. Cavalcanti Proença, com vistas ao destino de Tatarana, é um rio baldo, isto é, inútil, falho: jagunço frustrado na hora decisiva, quase ausente no último combate." E acrescenta: "Há em espanhol o vocábulo balda com o significado de 'cosa de poquísimo precio y ningún provecho', donde se teria originado o termo baldroca, uma dessas palavras que só têm existência em fórmulas rítmicas. adivinhas, canções e adágios". Por fim, e entretanto, Arroyo cita, em nota, um trecho de GSV que poderia endossar a tese do "frustrado" Baldo, de Proença, da qual, como veremos, o pesquisador desconfia: Baldo, você carecia mesmo de estudar e tirar carta-de-doutor, porque para cuidar do trivial você jeito não tem. Você não é habilidoso. (GSV, p. 95)

128 ALBERGARIA, Consuelo. Bruxo da linguagem no Grande sertão: leitura dos elementos esotéricos presentes na obra de Guimarães. Rio de Janeiro, Tempo Brasileiro, 1977.
} 
ressalta que a diferença entre Riobaldo e os outros jagunços está nos objetivos: "Se uns querem vencer a batalha, o outro pretende assumir a totalidade do seu ser, através do conhecimento."

A interpretação de Albergaria, também longe de qualificar as atitudes de Riobaldo como apenas negativas, malogradas, frustradas ou inúteis, destaca o homem em estado de falta, de procura e de busca da compreensão do seu ser. Diferentemente do que condena Bolle, de ver na significação do nome o caráter "baldo", "frustrado" ou, por compensação à suposta frustração que move o personagem, a representação de alguém que atingiu a "plenitude", Albergaria - aparentemente concordando com Candido, em "O homem dos avessos", de que o que há, em Grande sertão: veredas, é a proposta de um "rito iniciatório equivalente ao de certos romances de Cavalaria" "129 -, pelo contrário, propõe a busca e não a polarizada perda ou o pleno alcance dessa plenitude. Na visão da pesquisadora, com a qual tendemos a concordar, a luta de Riobaldo não se restringe a um plano físico ou concreto, mas o ultrapassa ou o complementa, de onde vem a opção de Rosa pelo verbo baldear, na composição do nome do jagunço-protagonista de sua obra principal.

Se baldear sugere uma ideia de movimento, com a transferência de algo de um lugar para outro, e o balançar, podemos, retomando a imagem do rio, interpretar essa ideia de movimento, em Rosa, como o fluir das águas, que faz do rio o símbolo do tempo e da transitoriedade, da renovação constante e também de duas dimensões: da superfície e da profundidade, da vivacidade e da tranquilidade, do claro e do escuro, do velho e do novo, do sereno e do bravio, do físico e do metafísico, todavia, todas em suas possíveis reversibilidades, permitindo ao "narrador-rio" do romance abrir mão das duas margens convencionais em busca de uma "terceira margem do rio", da busca da dialética unidade na dualidade.

O baldear evoca, portanto, a imagem do rio com a sua oscilação e nos remete a um narrador quase hamletiano em busca de um sentido, de um rumo, de uma certeza, a meio e meio das duas margens, e, ao mesmo tempo, sugere um rito de passagem para Riobaldo, o baldo rio, representando a transição e a mudança de uma situação para outra e de um mundo aparente, físico, bruto, da jagunçagem e suas andanças, para outro, o mundo da busca da religiosidade, da transcendência e da sabedoria. E, como na alquímica harmonia entre contrastes, yin e yang do Tao, proposta por Utéza e tão bem quista por Rosa, parece que essas duas perspectivas não se opõem, mas se complementam. Se uma aparenta imobilizar, a outra leva à ação, à procura, ao movimento. Se uma demonstra a dúvida, a incerteza, a falta de sentido, a outra proporciona o

${ }^{129}$ Em CANDIDO (1991), lemos:

Sinal interessante de contaminação dos padrões medievais é a carreira do narrador Riobaldo, de nascimento ilegítimo como tantos grandes paladinos, a começar por Roldão e Tristão. A princípio é uma espécie de escudeiro, adido a Hermógenes, a quem serve no combate; em seguida, após as provas de fogo, é armado cavaleiro, ao gesto simbólico em que Joca Ramiro lhe dá o rifle; mais tarde, alcança a chefia, após um ritual de iniciação e em consequência do sacrifício de outros chefes (...) Aliás, com este último traço nos encontramos em presença não apenas dos elementos medievais, mas de certas constantes mais profundas, que estão por baixo das lendas e práticas da Cavalaria e vão tocar no lençol do mito e do rito. (p. 302) 
preenchimento, a persistência, a fé e o desejo de conquista. Como a baldeante "Olererê baiana"130, cantiga de guerra dos jagunços (transcrita quatro vezes no romance):

\author{
Olererê, baiana... \\ eu ia e não vou mais: \\ eu faço \\ que vou \\ lá dentro, oh baiana! \\ e volto do meio pra trás...
}

Espécie de hino cantado por todos, "Olererê baiana" é a cantiga do erro, do ir e voltar, da guerra, da inconsequência dos atos humanos, da alegria fingida no coração, da frustração, mas, ao mesmo tempo, é uma canção que dá coragem, que faz esquecer o cansaço, as duras e pesadas coisas da vida, e seguir em frente, canção que une em nome de um ideal, de uma busca, aprendida por Riobaldo no momento exato em que, frustrado, incompleto, soubera da morte de Siruiz: E Siruiz tinha morrido. Então me instruíram na outra, que era cantiga de se viajar e cantar, guerrear e cantar, nosso bando, toda vida. (GSV, p. 192-193)

Apesar do gingado da cantiga evocar as relutâncias típicas de Riobaldo - em concordância com os estudos de Moura -, ela também ajuda o baldo herói a, coletivamente, confrontar suas frustrações, provar sua audácia, sua capacidade de guerrear. Nas palavras de Arroyo (1984: 132): "canção considerada bastante representativa tanto da condição jagunça como das oscilações de Riobaldo".

Machado, em seu Recado do nome, ressalta que o nome Riobaldo marca as mudanças de curso de um personagem que não se fixa num único caminho e que se encontra num permanente fluir, tomando o rio por modelo: "Como o rio, Riobaldo corre incessantemente. E, como o rio Urucuia, ele nunca chega ao mar, frustrado em sua vida de jagunço" (2003: 63). Na voz de Riobaldo:

$O$ rio não quer ir a nenhuma parte, ele quer é chegar a ser mais grosso, mais fundo. $O$ Urucúia é um rio, o rio das montanhas. (...) Recolhe e semeia areias. Fui cativo, para ser solto? (...) Mesmo na hora em que eu for morrer, eu sei que o Urucúia está sempre, ele corre. O que eu fui, o que eu fui. (GSV, p. 450-451)

\footnotetext{
${ }^{130}$ GALVÃO, Walnice Nogueira, in: As formas do falso. São Paulo: Editora Perspectiva, 1972, p. 110, aponta que a canção-motivo do bando de jagunços de Riobaldo faz lembrar a famosa canção de Lampião, gravada em disco por Vanja Orico: "Olê mulher rendeira/ Olê mulher rendá/ Tu me ensina a fazer renda/ Que eu te ensino a namorar". Segundo Galvão, tal lembrança se dá por quatro motivos: a) por ser cantiga de bando; b) por não ter refrão bélico; c) pelo exclamativo inicial (Olê) e d) por referir-se à mulher (rendeira ou baiana, na conclusão da autora). ARROYO (1994: 211) ressalta, porém, que Ranulfo Prata, in Lampião, registra a canção de Lampião com versos diferentes: "Ou muié rendera/ Ou muié renda/ Choro levo comigo/ Soluço vai no emborná”. E o mesmo Arroyo (1994: 133) aponta que a canção de GSV lembra, pelo contraste mecânico da atitude (faço que vou e volto do meio) uma outra, popular, referente ao mineiro que "tem mau costume: chama a gente e vai-se embora". Em A boiada, ROSA (2011: 168), encontramos - na edição fac-símile da página 59 da caderneta datiloscrita da viagem de 1952 -, em meio a anotações de outras tantas canções ouvidas e colhidas nos sertões de Minas, tal canção-motivo quase que na forma mesma em que fora apresentada no romance: "Olê rerê, Baiana,/ Eu ia e não vou mais!/ Eu faço que vou lá dentro, Baiana,/ e volto do meio pra trás."
} 
E Riobaldo se compara novamente a um rio - o mesmo frustrado rio Urucuia que nunca deságua no mar, apontado por Machado, mas que, talvez, não queira mesmo ir a nenhuma parte, queira é ficar mais grosso, mais fundo, queira é não desistir de buscar esse mar, de se buscar nesse mar -, quando continua, com os primeiros versos seus, para juntar aos antigos, as coplas que ele mesmo resolveu compor, enquanto estava a pensar em Siruiz e já a quase se esquecer - se esquecer? - da canção pelo boiadeiro, numa madrugada de maio, entoada, e quando já começava a tomar as rédeas de seu destino na encruzilhada do ser ou não ser do tempo. Versos, todavia, que não cantou para ninguém, nem lhe deram refrigério:

\section{Urucúia - rio bravo cantando à minha feição é o dizer das águas claras que turvam na perdição.}

Após muito navegar - e como não poderia deixar de ser -, aportamos, novamente, às beiras da canção de Siruiz - ou nos versos que Riobaldo fez para complementá-la e dar sequência a ela -, e, agora munidos dos subsídios necessários, denotamos a importância da imagem do rio para tornar mais claros os caminhos de aproximação a essa canção de margens - primeira, segunda, terceira - ainda tão tênues e secretas, caminho de águas claras que turvam na perdição, tal e qual os próprios caminhos de Riobaldo em meio à sua travessia no grande sertão.

E, por falar em travessia, a relação entre rio e travessia, afirma Machado, fornece ainda uma outra dimensão ao nome Riobaldo, que também pode nos ajudar no anseio de decifrar a canção de Siruiz:

(...) quando um homem enfrenta um rio para atravessá-lo, sem pontes ou embarcações, contando apenas com seus próprios recursos, tem que descobrir o VAU DO RIO. Essa procura, RIOVAU-DO a traz em seu Nome e a dissemina. (MACHADO, 2003: 64)

Para Riobaldo, o vau - parte mais rasa de um rio, por onde se pode passar a pé, a cavalo ou com a boiada - significa alegria e coragem: $O$ vau do mundo é a alegria! (...) Vau do mundo é a coragem... (GSV, p. 321) Deus é alegria e coragem... (GSV, p. 329), ou seja, o vau é o próprio Deus. De onde Machado defende a ideia de que a procura do vau por onde realizar a travessia do sertão, do mundo, da existência, confunde-se, para o herói buscador, com a procura de Deus e da religião. Assim, endossa-se a tese de que Riobaldo encerra em seu nome a reversível e dialética oscilação entre dois polos: o de Deus e o do diabo, o do bem e o do mal, o do masculino e o do feminino, o do físico e o do metafísico. Riobaldo, rio repleto de meandros, oscila e não se resolve, seguindo frustrado e baldo, em regime de vazante e vazio, e banhando os dois lados, regando as duas margens, mas não se fixando em nenhuma delas, todavia sem jamais deixar de buscar o que talvez 
pudesse ser uma terceira margem, a "terceira margem do rio". E é essa "baldanza" que, feito a guerreira canção "Olererê baiana", o faz seguir, o instiga a procurar o vau, e não lhe permite, de todo, remansar.

A "frustração" de Riobaldo está ligada fundamentalmente, como observou Augusto de Campos ${ }^{131}$, à sua dúvida existencial, a dúvida hamletiana do "ser ou não ser?”: ser ou não ser filho do próprio padrinho, o coronel Selorico Mendes? Ser ou não ser jagunço? Ser ou não ser homem de letras? Ser ou não ser apaixonado pelo(a) companheiro(a) Diadorim/Deadorina? Ser ou não ser chefe dos jagunços? Ser ou não ser um pactário?... Não à toa, no momento do suposto pacto com o diabo, Riobaldo pede para ficar sendo. Dúvida existencial esta que encontra o seu paralelo definitivo nos versos finais, em copla incompleta, escritos pelo próprio Riobaldo para a continuação que resolveu dar à canção de Siruiz: Remanso de rio largo.../ Deus ou o demo, no sertão...

Talvez, intuitivamente, Riobaldo, desde o pedido ao diabo para ficar sendo ${ }^{132}$ até os versos finais de sua canção, tivesse tomando consciência, já, de que não era o "ser ou não ser", o "Deus ou o demo", mas, sim, o "ser $e$ não ser", o infindado ficar sendo, o "Deus $e$ o demo" que remansariam e remansaram remansaram? - as águas do largo e baldo rio Urucuia, símbolo e alegoria de si mesmo, antes do encontro com o São Francisco, pau grosso, em pé, enorme... (p. 624), “deus fluvial do sertão”, e, após, só após, da malograda - malograda? - aproximação com o mar.

Nas palavras de Cavalcanti Proença, em Trilhas no Grande Sertão $o^{133}$ - palavras essas confrontadas por Bolle e que geraram desconfiança em Arroyo e Hazin, mas das quais não podemos abrir mão e de, sobre elas, refletir -,"Rio-Baldo não se realizou como jagunço":

(...) frustrado na hora decisiva, ausente do último combate, assiste, da janela do sobrado, imobilizado pelo ataque, ao duelo entre Diadorim e Hermógenes. Diadorim morre, o rio muda de rumo: "O senhor nonada conhece de mim: sabe o muito ou o pouco? O Urucuia é ázigo... Vida vencida de um, caminhos todos para trás...”. (PROENÇA, 1958: 40)

Mas será que Riobaldo não se realizou mesmo como jagunço?... Será que o desejo de voltar atrás significa a não realização do caminho?

É certo que, com a morte de Diadorim, vida vencida de um, mudam-se os rumos e desígnios da saga de Riobaldo e ele, contrariando as leis das águas, desnorteado, ázigo, singularmente esquece o seu curso esperado e só consegue desejar fluir para trás.

\footnotetext{
${ }^{131}$ CAMPOS, Augusto de. "Um lance de 'dês' do Grande Sertão". In: COUTINHO, Afrânio (org.). Coleção fortuna Crítica: Guimarães Rosa. Rio de Janeiro: Civilização Brasileira, 1991.

${ }^{132}$ Essa locução verbal, em forma nominal e no gerúndio, não possui flexão de tempo e de modo. Indica uma ação contínua do que está, esteve ou estará em andamento, ou seja, um processo verbal jamais finalizado, todavia eternizado num presente contínuo.

${ }^{133}$ PROENÇA, M. Cavalcanti. Trilhas no Grande Sertão. Cadernos de Cultura. Rio de Janeiro: Imprensa Nacional, MEC, 1958.
} 
A correnteza era Diadorim - Diadorim, esse, o senhor sabe como um rio é bravo? E toda vida, de longe a longe, rolando essas braças águas, de outra parte, de outra parte, de fugida, no sertão? (GSV, p. 444) - e, sem Diadorim, sem seu leme, seu rumo, seu prumo e aprumo, seu vau, sua correnteza, não haveria o porquê de Riobaldo prosseguir. O fluxo das águas, assim como o fluir dos tempos, estacionaria, cristalizarse-ia, e tudo se transmutaria em plúmbeo temor de porvir.

Desde a primeira travessia era Diadorim quem movimentava as águas, Riobaldo era o medo. Quando, pela primeira vez, ainda garoto, Riobaldo atravessou, em bamba canoa, o São Francisco, foram as mãos do Menino, foram os olhos verdes do Menino, que o fizeram prosseguir. Riobaldo era só medo, medo e vergonha: Carece de ter coragem... (GSV, p. 122), dizia-lhe o serenado Menino que, mais tarde, seria reconhecido como Diadorim, tentando serená-lo também, preparando-o já para fazer tantos atos para dar corpo ao suceder. Muito tempo depois, remando vida solta, como jagunço já formado e aposentado, Riobaldo indagaria a si mesmo e a seu interlocutor forasteiro, buscando dar luz ao (con)fluir dos tempos: $\boldsymbol{E} \boldsymbol{u}$ me lembro das coisas, antes delas acontecerem... Com isso, minha fama clarêia? (GSV, p. 47).

Proença traz-nos à memória a transposição do de-Janeiro e o "grande medo" vivido pelo menino baldo em sua primeira travessia como antecipatórios de um medo e de um susto muito maiores:

Riobaldo é o Urucuia, o afluente, para quem o do Chico representa o fim, a morte. Por isso o susto foi de quem está em perigo de vida: "Medo maior esse que se tem, é de vir canoando num ribeirãozinho, e dar, sem espera, no corpo dum rio grande. Até pelo mudar”. E porque tinha medo: - "Daqui, vamos voltar? - eu pedi ansiado". (1958: 41).

Vida vencida de um, caminhos todos para trás... (GSV, p. 611), afirma Riobaldo, consternado, ao seu interlocutor forasteiro, desejando afluir de volta, asseverando que algumas situações não são passíveis de mudança e que, se a travessia é perigosa, o sertão não protege ninguém: $O$ sertão é sem lugar. - O senhor empurra para trás, mas, de repente, ele volta a rodear o senhor dos lados. Sertão é quando menos se espera. - Sertão - se diz-o senhor querendo procurar, nunca não encontra. De repente, por si, quando a gente não espera, o sertão vem. (GSV, p. 302).

Contudo, mesmo no sertão, rios não correm para trás e as águas continuam rumando ao mar. Retomando a voz do baldeante eu lírico da cantiga "Olererê Baiana” que, em seu verso final, volta do meio pra trás..., mas que, nem por isso, impede aqueles que a entoam de prosseguir no guerrear, no ambíguo e reversível Grande sertão rosiano, o que se propõe a "voltar para trás” é, muitas vezes, convite ao lançar-se à frente. E, nas Trilhas no Grande Sertão, Proença dá sequência à análise que faz do curso de Riobaldo-Urucuia - frustrado? - e de seus simbólicos caminhos em busca do intangível aportar - aportar? - nas margens do ainda mais intangível e infinito mar (os grifos são meus): 
Na chefia do bando, ensandecido pela sensação do poder que lhe dera o pacto, numa permanente luta interior ele [Riobaldo] se dispõe a matar o homem da égua e da cachorrinha. É uma das melhores páginas do livro o diálogo entre o Diabo e a consciência do jagunço, afinal vitoriosa, porque "o perfume do nome da Virgem perdura muito; às vezes dá saldo para uma vida inteira..." Então quando o homem se afasta, os ombros sacudidos pelos soluços, como se estivessem recebendo o açoite de todos os ventos, Riobaldo tem vontade de chorar: "Sobreveio em mim a estúrdia aragem de chorar também... Eu, nas margens do mar."

Nas margens do mar, longe, longe, longe de tudo aquilo, do cangaço, do crime, do remorso. A infinita distância. $\mathrm{O}$ mesmo simbolismo transparece quando deixa as moças do Verde-Alecrim, onde nunca mais voltaria: "as flores, naquele povoadozinho, como se para mim ficassem na beira dum mar..." (1958: 66-67).

Mesmo o Urucuia jamais alcançando o mar, mesmo desembocando no São Francisco, mesmo Riobaldo desejando, com e como o rio, voltar atrás, em outros tantos momentos da narrativa do Grande sertão, mesmo com Diadorim morta - todavia com o "perfume do nome da Virgem” perdurando muito - se fará presente na travessia do herói o simbolismo do mar, do adiante mar, do inalcançado e alcançado mar, mas em nenhum outro momento de maior força expressiva do que o do pensamento do jagunço apaixonado na derradeira luta de morte de Diadorim.

Ainda nas palavras de Cavalcanti Proença:

Da janela do sobrado, ele [Riobaldo] vê Diadorim e Hermógenes pegados à faca; vê o alto esguicho de sangue jorrando do pescoço do judas; não vê mais o amigo e pressente que tudo acabou. Então, quer chorar e rezar: "Soluço que não pude, mar que eu queria um socorro de rezar uma palavra, bradada ou muda; e secou: e só orvalho em mim, por prestígios do arrebatado no momento, foi imaginar a Nossa Senhora assentada no meio da igreja... Gole de consolo. Como lá em baixo era fel de morte, sem perdão nenhum." (1958: 67).

Mar e pranto, mar e o consolo do perdão, mar e Nossa Senhora, mar e morte, mar e infinito, mar e orvalho, mar buscado, mar inalcançado, mar alcançado no inalcançável. Imagens paralelas durante toda a travessia de Riobaldo. Diadorim morreu, Riobaldo abandona o cangaço. Doente, desesperado, sem rumo, desejando voltar atrás, mas seguindo adiante. Nesse momento, de final da saga e da sina jagunça, Riobaldo é, mais do que nunca, o Urucuia, afluente, para quem o São Francisco representa o fim, a morte, mas que, em novas águas, misturadas, prossegue.

O Urutu Branco, junto com seus homens solidários, todos em pé, fechando praia de mar, destitui-se de seu posto e torna-se um barranqueiro do São Francisco - aliás, num lugar do sertão em que o rio se encontrava muito perto de sua foz, muito perto do encontro com o mar - e, querendo dar conta de toda a amargura de até então, ressequido, desabafa: - Chapadão. Morreu o mar, que foi. (GSV, p. 617) 
Medo maior é de vir canoando num ribeirãozinho, e dar, sem espera, no corpo dum grande rio. Até pelo mudar, afirmara o Riobaldo ainda criança ao Menino, a Diadorim, no voltar atrás do tempo até o transpor do de-Janeiro, como que, de fato, pressentindo o final da amedrontadora travessia comum. Para Proença, esse medo, se ainda perdura, já não se confessa no barranqueiro de rio:

[...] já se dilui em meditação no velho Riobaldo que, na barranca do São Francisco, relembra as voltas e corredeiras do Urucuia. Perto da foz, Deus é a sua única preocupação, ideia fixa: "Consegui o pensar direito: penso como um rio tanto anda: que as árvores das beiradas mal nem vejo". Longe da luta que levara sem descanso, de vereda em vereda, realizou, de certo modo, aquele desejo de liberdade, que o angustiava, quando "queria a minha vida própria por meu querer governada". Sabe que Deus é sossego e paciência, que só o demônio "gosteja" de violência: "Até as pedras do fundo, uma dá na outra, vão se arredondinhando lisas, que o riachinho rola". (1958: 41-42).

Como aponta Proença, o Grande sertão: veredas é um "romance de rios, romance de afluentes espraiados no sertão, sem saída para o oceano, o mar nele aparece como o grande desconhecido, mistério que se associa à morte, à eternidade, ao fim de tudo, quando a vida deságua no infinito.” (1958: 65).

Na geografia sertaneja espelhada por Rosa, o São Francisco é que chega à grandeza do mar, o Urucuia, não. Mas é o Urucuia que alimenta o São Francisco. Feito o protagonista do Grande sertão rosiano, o Urucuia é um rio baldo, é a frustração que alimenta, a "baldanza" que movimenta, o afluente que conduz ao rio maior, mais grosso, mais fundo, e que faz do mar não apenas promessa, mas possibilidade. Rio de paz das águas, mas que tão às brabas vai, rio de quem Riobaldo toma as bênçãos e cujas águas refletem sua saga, seu destino e seus mistérios.

Urucuia, rio e serpenteantes margens de rio nos quais mergulharemos e aportaremos ainda mais a fundo, ainda mais adentro, em busca do decifrar desse canto das águas que é, ao mesmo tempo, a canção de Siruiz e a canção de Riobaldo. 


\section{CANÇÃO DE SIRUIZ, NEBLINA DE RIOBALDO}

O que eu guardo no giro da memória é aquela madrugada dobrada inteira: os cavaleiros no sombrio amontoados, feito bichos e árvores, o refinfim do orvalho, a estrela-d'alva, os grilinhos do campo, o pisar dos cavalos e a canção de Siruiz. Algum significado isso tem?

(Grande sertão: veredas, Guimarães Rosa) $)^{134}$

Como vimos, a nostalgia e a incessante procura de Guimarães Rosa pelo nome faz eco em Riobaldo. Muita coisa falta nome (GSV, p. 125), afirma o jagunço aposentado a seu interlocutor-viajante a respeito das lembranças de sua primeira travessia com o Menino, não conseguindo exprimir em palavras a experiência que representou, para o então pequeno herói adoecido, esse encontro, essa aprendizagem primeva que é a travessia de dois rios, o de-Janeiro ${ }^{135}$ e o São Francisco, o do menino e o do homem, pelas mãos de Diadorim, enigma de um caráter e de um destino. E o mesmo acontecera com o primeiro encontro com Siruiz e sua canção: Algum significado isso tem? (GSV, p. 138)

Se no nome Riobaldo encontramos a síntese e a gênese mitopoética da travessia do nomeado herói, e, como vimos com Candido (1991), se homem e paisagem, em Grande sertão: veredas, são mesclas da realidade e símbolo, e, ainda, como apontou Schwarz, se "no coração mesmo da linguagem, tornada fluida e refeita maior, o escritor realiza esse seu constante itinerário da realidade para o fantástico, do mínimo para o imenso, do chulo para o símbolo cósmico" (1965: 36), atentemos, então, para a enigmática canção de Siruiz em busca de um novo mergulho especulativo, um novo vislumbre, expansão de visão nessas águas de tantos reflexos e nuances de significação que são as páginas de Rosa. E, claro, atentemos para a fixação de Guimarães pela imagem do rio também na construção dos versos e das estrofes dessa tão importante balada boiadeira, desse meândrico canto das águas.

Já vimos que a canção de Siruiz, como um divisor de águas, quebrando as barras, acontece num momento fronteiriço da vida do adolescente Riobaldo, e, separando a noite do dia, o escuro do claro, ilumina sua existência, molha feito o orvalho suas ideias. A partir daí, não tardará sua fuga, abandonando a vida que levava na fazenda do padrinho para se tornar, depois, convidado por seu coração, jagunço e guerreiro. E os versos da canção iniciática o acompanharão por toda a vida, por toda a travessia, e serão recorrentes em toda a narrativa: tratando desde de sua vocação para as armas e para as letras até do seu amor pela moça virgem,

\footnotetext{
${ }^{134}$ Grande Sertão: Veredas. 19a ed. Rio de Janeiro: Nova Fronteira, 2001, p. 138.

${ }^{135}$ UTÉZA, in op. cit., relaciona o Rio-de-Janeiro, de Minas, com o deus romano Janus, "deus de duas faces, que toma conta de todos os lugares de trânsito" (1994: 256), deus das transformações e do novo, e chama a atenção para o fato de que o de-Janeiro não fica muito longe circunstância de cinco léguas - da fazenda onde, no momento da narrativa, Riobaldo, já como fazendeiro e barranqueiro de rio, se encontrava, ou seja, ao final da travessia o jagunço retorna para o lugar geográfico onde praticamente tudo começou.
} 
o Jagunço Diadorim, evocada(o) antes ainda de a balada ser ouvida pela primeira vez, e perseguida por toda a história e estória: Quando vou p'ra dar batalha/Convido meu coração...

Sem compreender ainda o significado da canção, Riobaldo, inconsciente e intuitivamente instigado pelas (en)cantadas e neblinadas palavras de Siruiz, feito o fluxo das águas entoado nos versos da própria cantiga, abandona seu caráter contemplativo e baldo - cristalizado, de chumbo, diriam os alquimistas - para se tornar, por meio de um suposto pacto demoníaco, um hipotético pacto fáustico ${ }^{136}$ - com traços comuns com o do próprio Fausto, de Goethe -, um homem de ação e, ao final, perdendo o que mais buscava, mirando e não vendo, voltar-se, novamente, ao remansado mundo da contemplação, da narrativa nostálgica do sertão que já não havia, todavia contemplado com o dom de contar e cantar estórias, orficamente tocado pelas Musas.

Tomemos, na íntegra, a letra da canção que vaticina a estória de toda a vida de Riobaldo:

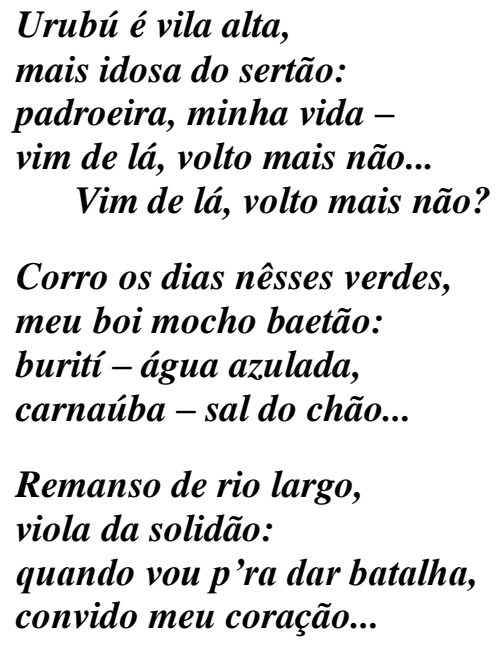

A vila do Urubu, denotada no primeiro verso da canção de Siruiz, só aparece em Grande sertão: veredas algumas páginas após o meio do livro, na entrada do bando na "Tapera Nhã"137, também chamada de Guararavacã do Guaicuí.

\footnotetext{
136 ALBERGARIA, Consuelo, in op. cit., retomando depoimento de Rosa a Lorenz, no qual o autor afirma que "Riobaldo não é Fausto" (LORENZ: 1991: 95), afirma que o suposto pacto de Riobaldo com o diabo não é uma reedição do mito fáustico: "(...) o depoimento de Rosa a Günter Lorenz auxilia na invalidação das interpretações de Grande sertão: veredas como uma reedição do mito fáustico: 'Riobaldo não é Fausto'. E nem poderia ser, uma vez que na tragédia de Goethe, o demônio, Mefistófeles, aparece visível e comprovadamente, dialogando e fechando o pacto com o protagonista, o que absolutamente não acontece em Grande sertão: veredas, em que o máximo que se poderia aceitar seria a permanência da dúvida." (1977: 37). De acordo com Walnice Nogueira Galvão, o redemoinho que dá origem a uma das frases-chaves e epígrafe do romance - O diabo na rua, no meio do redemunho - é o que mais se aproxima da materialização do demônio, configurando mais uma das tantas ambiguidades da obra: "O diabo, algo concretizado e corporificado no meio de algo móvel e envolvente como o redemoinho é a imagemmor do certo no incerto" (1972: 129). Concordando com Albergaria e com Galvão, elencaremos os pontos em comum entre o suposto pacto de Riobaldo e os mitos fáusticos, mas manteremos a permanente dúvida.

${ }^{137}$ Conforme o Léxico de Guimarães Rosa, de Nilce Sant'Anna MARTINS, que se baseia em carta de Rosa a Bizzarri (2003: 85), "Nhã” é corruptela de senhora, todavia, e ao mesmo tempo, o dicionário aponta Nhã-ã, palavra com a qual "nhã" faz eco, como uma fórmula propositalmente reduzida e deturpada de Anhangá, o diabo dos índios tupis e guaranis. Além disso, transcrevendo a carta a Bizzarri, temos que "NHÃ-Ã (nhã-ã, nhanhan) reluz o 'esqueleto', o substrato de nenhum, ninguém, etc. = isto é, o nada, a negação = o mal, o Diabo.”.
} 
Riobaldo, ao tratar desse momento de sua vida - então jagunço já formado e grande atirador, cognominado "Tatarana ${ }^{138}$, lagarta de fogo" -, afirma ao seu interlocutor que já lhe contou tudo e que, para se saber do resto, bastava pôr atenção no que já havia narrado: Aqui eu podia pôr ponto. Para tirar o final, para conhecer o resto que falta, o que lhe basta, que menos mais, é pôr atenção no que contei, remexer vivo o que vim dizendo (GSV, p. 324). O que poderia ser verdade, se o seu ouvinte-forasteiro - ou nós e, talvez, até ele próprio - compreendesse - compreendêssemos - tudo o que a canção do Siruiz estava - e está - nos dizendo e revelando. Mas isso não acontece, tanto é que Riobaldo prossegue a entrançada narrativa.

Na glosa do meio do livro (GSV, p. 325 a 329) - já aludida neste estudo, com a transcrição de um trecho da correspondência explicativa de Rosa com Mário Calábria -, a Vila do Urubu é referida - com um ponto de interrogação - como estando na fronteira entre Minas e Bahia: Urubú ${ }^{139}$ Um lugar, um baiano lugar, com as ruas e as igrejas, antiquíssimo [...] Aqui é Minas; lá já é a Bahia? (GSV, p. 325). Aí o herói começa a fazer uma espécie de balanço da sua vida. Às portas da Tapera - do - Nhã, pensa no diabo, no demo, no medo $^{140}$, pensa em Deus, e diz: Travessia, Deus no meio, e, mais adiante, afirma: $O$ São Francisco partiu minha vida em duas partes. Nesse trecho da narrativa, Riobaldo nos sinaliza que ele também está in medias res, no meio de alguma coisa (sem dizer que estamos precisamente no meio do livro).

Trata-se de um momento de tempestuosa e intempestiva precipitação de pensamentos, lembranças, lugares, nomes, signos, símbolos, tudo misturado, dissolvido, mesclado e amalgamado - assim como um rio em tororoma ou tal e qual o modo como os livros sagrados, inclusive o Gênesis bíblico, referem-se ao Princípio da criação, ao tratar de suas cosmogonias -, num primevo caos informe, princípio de todas as formas, de onde tudo se origina.

O que está escrito, moîra (destino para os gregos), e o que se narra, entrançado, na voz de Riobaldo, com a dificuldade de, feito o livre-arbítrio, se recompor numa suposta justa ordem, ao invés de esclarecer, de glosar, confunde, atordoa, movimenta.

E, ainda na glosa e em tom epifânico, em diálogo com o Livro de Jó, do Antigo Testamento bíblico ou com o prólogo do Fausto de Goethe ${ }^{141}$-, o narrador tenta remansar - o seu interlocutor e a si: Mas o

\footnotetext{
${ }^{138}$ MARTINS, Nilce Sant'Anna, in op. cit., aponta que Tatarana, do tupi, tata'rana (semelhante a fogo), é uma "lagarta urticante capaz de provocar reações que variam de um eritema ligeiro a lesões mais extensas e fenômenos diversos" (2008: 484). Merece destaque, aqui, em comparação ao sofrimento vivido por Riobaldo em suas transformações durante toda a narrativa, o caráter autofágico das metamorfoses da lagarta até se tornar borboleta.

${ }^{139}$ UTÉZA, Francis, in op. cit., aponta em nota que, numa obra que figura na biblioteca de Rosa - T. Sampaio, O Rio São Francisco e a Chapada Diamantina, Bahia: Progresso, 1955 -, encontramos o seguinte: “O Urubu é uma vila pobre, das mais antigas do sertão, mas sem beleza. (1991: 100). Percebe-se, claramente, a semelhança entre a denotação de Sampaio e os dois primeiros versos da canção de Siruiz: "Urubú é vila alta/ mais idosa do sertão"

${ }^{140}$ Vide a relação anagramática entre as palavras demo e medo, ambas tantas vezes repetidas em Grande sertão: veredas.

${ }^{141}$ No Livro de Jó, do Velho Testamento, Deus incita Satanás a tentar Jó, até então estavelmente feliz e realizado em vida, tirando-lhe tudo a fim de provar e fortalecer sua fé. No prólogo do Fausto, de Goethe, no Empíreo, Deus incita Mefistófeles a se ocupar de outro bom servo, o Dr. Fausto, com o mesmo propósito.
} 
demônio não existe real. Deus é que deixa se afinar a vontade o instrumento, até que chegue a hora de se dansar. Travessia. (GSV, p. 325). Aparentemente de forma intuitiva, Riobaldo retoma a ideia da complementaridade entre "Bem" e "Mal", do diabo como instrumento de Deus. E a dança é um convite à evolução, à ascese, a um processo progressivo de esclarecimento, de busca por sabedoria, do afinar da vontade em que, para além do bem e do mal, a noção de pecado não é cabível - ou fazendo alusão às próprias palavras de Rosa em diálogo com Günter Lorenz, em que "ainda não se conheceu o pecado original": $\boldsymbol{O}$ que existe é homem humano. Travessia. (GSV, p. 624), afirma Riobaldo, ao final da narrativa de Grande sertão: veredas e, muito antes disso, já havia pontuado: (...) a água limpa é nas cabeceiras. $O$ mal ou o bem estão é em quem faz; não é no feito que dão. (GSV, p. 97). A par disso e seguindo os conselhos do próprio Riobaldo, remexendo vivo o que ele disse a seu interlocutor - e nos diz e repete a cada nova leitura -, debrucemo-nos, então, sobre os primeiros versos da canção de Siruiz.

Se o urubu ${ }^{142}$ - ave que se alimenta de carne em decomposição - ordinariamente simboliza a morte, em seu alto voo, viajando por todas as partes - olhando tudo de cima, desde tempos muito antigos, idos e idosos tempos - é também a fonte de vida do sertão, ave da renovação, eliminando tudo o que já não presta, limpando o mundo de seus dejetos, separando o perecível do imperecível, reciclando e transformando o velho em novo.

Para Utéza, o "Urubu simboliza o Útero Primordial que o quarto verso da copla - vim de lá, volto mais não... - instala como ponto de partida de uma vida que decorreria de uma direção irreversível.” (1994: 269). Todavia o crítico chama a nossa atenção para o ponto de interrogação e as reticências do final do quinto verso $^{143}$, que retoma o anterior: Vim de lá, volto mais não?... Tal verso, para o estudioso da alquimia em Rosa, pode ser interpretado como uma suposta forma de reintegração, desejo de religação com o Cosmos, com a Criação, com Deus. Utéza não citou isso, mas há um dado relevante no romance que pode endossar sua tese: a Vila do Urubu - essa ou outra qualquer do sertão, necessariamente também denominada Urubu parece ser a terra natal do guia e mestre espiritual kardecista de Riobaldo, como afirma a glosa à canção de Siruiz, do meio do romance: Compadre meu Quelemém outrotanto é homem sem parentes, provindo de distante terra - da Serra do Urubú do Indaiá. (GSV, p. 326). Sendo assim, os urubus, "pela guisa”, não

\footnotetext{
${ }^{142}$ Rosa tem certa predileção pelos urubus, em sua literatura, quando trata de mensagens místicas ou profecias. Em "O recado do morro", vemos, por exemplo, que o Gorgulho, primeiro dos recadeiros do morro, também nomeado de Malaquias - que, etimologicamente significa "o mensageiro de Deus" - era um urubuquara que morava sozinho numa casa de urubus, a "Lapa dos urubús", denominada, depois, como a "Lapinha do Gorgulho". Logo no início dessa mesma novela, o narrador evidencia os dons premonitórios dos urubus: "Por resto, o mudo passar alto dos urubus, rodeando, recruzando -; pela guisa esses sabem o que-há-de-vir." (ROSA, 1994: 619).

${ }^{143}$ Coplas são pequenos poemas líricos ou canções de inspiração popular constituídos geralmente por estrofes rimadas de quatro heptassílabos. Merece nota, aqui, o fato de Rosa criar um quinto verso para a primeira estrofe da canção de Siruiz, que retoma o quarto, todavia quebrando com a regra das quadras, e interrogando-o. Segundo o Dicionário de Símbolos, as significações simbólicas do número quatro remetem ao equilíbrio, ao sólido, ao tangível, e o cinco simboliza a perfeição, o universo e a união nupcial, complementaridade entre feminino e masculino. (CHEVALIER \& GHEERBRANT, 2000: 241-245 e 759-762)
} 
apenas "sabem o que há-de-vir", como afirma o narrador de "O recado do morro", como também podem se tornar mestres e protetores dos caminhos, oferecendo abrigo e casa a eremitas, sacerdotes e recadeiros. ${ }^{144}$

Deixando o simbolismo, as mitologias e a metafísica um pouco de lado, poderíamos dizer que mesmo geograficamente falando, a irreversibilidade do retorno se torna discutível em Grande sertão: veredas, afinal, como já apontamos neste estudo, em concordância com as pesquisas de Viggiano, o final da travessia de Riobaldo - a fazenda herdada de Selorico Mendes, outrora ponto de encontro de Riobaldo com Joca Ramiro e com a canção de Siruiz - se dá bem perto de onde tudo começou, o cruzar do de-Janeiro, rio que deságua no São Francisco.

Com o terceiro verso da canção - padroeira, minha vida -, não há como deixar de lado a evocação à Virgem Maria, padroeira de toda a vida na travessia de Riobaldo. O jagunço, como muitos mineiros, aliás até nos dias atuais, é devoto de Nossa Senhora da Abadia $^{145}$ e, no peito, bem perto do coração, carrega o tempo todo o escapulário da Virgem das Montanhas. E, mesmo após o suposto pacto com o diabo, quando recebe o cavalo Siruiz de Seu Habão - primeiro fazendeiro a reconhecê-lo como chefe dos jagunços, após a destituição de Zé Bebelo -, ele não abre mão de sua devoção a Nossa Senhora. Por alvíssaras de mercê com o fazendeiro, desfaz-se das verônicas e dos breves que possuía, presenteando o oportuno amigo com eles, mas não do escapulário:

As verônicas e os breves ele vendesse ou avarasse para os infernos. Comigo só o escapulário ainda ficou. Aquele escapulário, dito, que conservava pétalas de flor, em pedaço de toalha de altar recosturadas, e que consagrava um pedido de benção à minha Nossa Senhora da Abadia. (GSV, p. 457)

Apenas num entusiasmado momento posterior, Riobaldo resolve - ou consegue - se apartar do escapulário: quando o oferece para Diadorim, sua outra padroeira, outra virgem que também guiava sua vida

\footnotetext{
${ }^{144}$ As grutas e as cavernas eram os locais de morada dos sacerdotes gregos, que viviam solitariamente e em castidade, assim como Malaquias e Zaquias de "O recado do morro". O recado enviado pelo morro é uma alusão aos oráculos gregos do templo de Delfos. Gorgulho, pouco antes de dar o recado, diz: Não me venha com Loxías! Conselho que não entendo, não me praz: é agouro! (ROSA, 1994: 624). Lóxias - em grego, o obscuro - é um dos epítetos de Apolo no santuário de Delfos e uma de suas características, como oráculo, era o de enviar "recados" enig máticos, de difícil compreensão. Como, aliás, é também o "recado" da canção de Siruiz.

145 ARROYO (1984: 219) cita Augusto de Lima Júnior e sua História de Nossa Senhora em Minas Gerais, Imprensa Oficial, 1956, p. 199 a 202, para tratar da devoção mineira à Nossa Senhora da Abadia: "A invocação de N. S . da Abadia do Bouro é o caso único de sobrevivência do local original de sua devoção em Portugal. Bouro é o nome do vilarejo e do convento cisterciense próximo à cidade de Braga, onde se teria iniciado o culto de Nossa Senhora da Abadia, daí se transferindo para o sertão mineiro. O nome integral sobreviveu apenas em Água Suja, ou Romaria.” A primeira imagem da Santa pertenceu a uma abadia, o Mosteiro das Montanhas, que ficava na região do Bouro por volta do ano 883. Quando os muçulmanos invadiram Espanha e Portugal, os monges fugiram e enterraram a imagem. Por volta de 1100, Pelágio Amado, nobre ancião convertido, abandonou sua vida de riquezas na corte e foi viver na Ermida de São Miguel, perto de Braga. Lá, passou a morar com um velho eremita. Certa noite, viram uma luz que vinha do meio de um vale próximo. Na noite seguinte o fato se repetiu. Então, entre a noite e o amanhecer, foram ao local em busca da origem da luz e encontraram a imagem de Nossa Senhora da Abadia escondida no meio das pedras. Com a redescoberta, ergueram, no local, uma pequena e rústica capela e colocaram a imagem. A notícia chegou ao arcebispo de Braga, que foi visitar o local e, depois de ver a pobreza em que os dois eremitas viviam, mandou construir ali uma igreja de pedra lavrada, digna de abrigar os dois santos e a imagem de Nossa Senhora. Aos poucos, outros eremitas se uniram aos dois e a fama dos milagres de Nossa Senhora da Abadia se espalhou. Peregrinações começaram a acontecer. Fiéis de todos os cantos vinham rezar, pedir e agradecer pelas graças alcançadas. D. Afonso Henriques, rei de Portugal, foi visitar o santuário e deixou ali uma grande doação para o culto e as necessidades daqueles servos de Deus. A devoção à Nossa Senhora da Abadia chegou ao Brasil através dos portugueses e se instalou primeiramente em Minas Gerais.
} 
e sua alma, dona de seu coração: (...) enfiei mão: por entre armas e cartucheiras, e correias de mochilas, abri à berra meu jaleco e a minha camisa. Aí peguei o cordão, o fio do escapulário da Virgem - que em tanto cortei, por não poder arrebentar - e joguei para Diadorim, que o aparou na mão (GSV, p. 511)

Sobre Diadorim ${ }^{146}$ - e sua formosa parecença, aos olhos de Riobaldo, com Nossa Senhora de Abadia -, assim a descreve o jagunço apaixonado, ao tratar desse numinoso momento da estória, o momento em que lhe presenteia com o escapulário, quando a donzela-guerreira, numa espécie mesmo de dom de Deus, tocada pela graça, estende sua mão em ajuda a um lázaro:

(...) Diadorim, conforme diante de mim estava parado, reluzia no rosto com uma beleza ainda maior, fora de todo comum. Os olhos - vislumbre meu - que cresciam sem beira, dum verde dos outros verdes, como o de nenhum pasto (...) Sobre o que juro ao senhor: Diadorim, nas asas do instante, na pessoa dele vi foi a imagem tão formosa da minha Nossa Senhora da Abadia! A santa. (GSV, p. 511)

Minha padroeira é a virgem, por orvalho, diz a glosa do meio do romance. Siruiz, cadê a moça virgem?, perguntam os jagunços, numa orvalhada madrugada de maio, ainda na fazenda São Gregório da adolescência de Riobaldo, entre a noite e o amanhecer, ao pedirem pela canção de Siruiz. Sem saber, Riobaldo carregava consigo, bem perto do coração, suas duas padroeiras, suas duas virgens, motivos de amor e de devoção, pelas erranças, idas e vindas - idas e vindas? - no sertão.

Por fim, o escapulário seria enterrado com Diadorim ${ }^{147}$, após a sua morte - após "a deus dada" -, para nunca mais: A mulher lavou o corpo, que revestiu com a melhor roupa que ela tirou da trouxa dela mesma. No peito, entre as mãos postas, ainda depositou o cordão com o escapulário que tinha sido meu. (GSV, p. 615)

Mas para nunca mais mesmo?... É possível retornar aonde e quando tudo começou, ao mais idoso e primevo e, com isso, na forma de alétheia, de verdade, iluminação e revelação, vencer o esquecimento e a morte e, contrariando o mito de Orfeu, seguir sem olhar para trás?... A primeira estrofe da canção, glosada por Riobaldo, mais desatina que esclarece. Vejamos um trecho do que o narrador glosou: Saí, vim, destes meus Gerais: voltei com Diadorim. Não voltei? Travessias... Deus no meio. (GSV, p. 325)

\footnotetext{
${ }^{146}$ REINALDO, Gabriela, in op. cit., analisa o nome de Diadorim: “[O nome] Maria Deodorina da Fé Bettancourt Marins, só é dito depois de $a$ deus dada, após a sua morte. Deodorina $=$ Deodora $=$ Deodoros $=$ Dom de Deus, não se sabe, não se pronuncia. Só é Reinaldo para os jagunços, só é Diadorim para Riobaldo." (2005: 21). Diá, em GSV, segundo Nilce Sant'Anna Martins, é uma interjeição para Diabo, também cujo nome não se pronuncia. (2008: 169). Nota-se aí, novamente, a complementaridade entre Bem e Mal, harmonia de opostos. Aqui, facilmente, poderíamos traçar uma analogia do nome Diadorim com Beatriz (do latim Beatrice, a partir de beatus, "abençoado", e beare, "para fazer feliz"), da Divina Comédia, que, como a Diadorim para Riobaldo, é devoção de vida e de morte de Dante, guia e alimento para o espírito do poeta.

${ }^{147}$ Merece lembrança que a outra Virgem de devoção de Riobaldo, a Nossa Senhora da Abadia, imagem presente no escapulário, assim como Diadorim, foi um dia enterrada na esperança de ser, posteriormente, redescoberta e, num ato de fé e de milagre, ressuscitada em seus dons e em sua graça. Aqui, podemos fazer referência, novamente, aos últimos versos da primeira parte da canção vim de lá, volto mais não.../ Vim de lá volto mais não? Tais versos suscitam desconfiança a respeito da direção irreversível da vida rumo à morte e da irreversibilidade do destino.
} 
Para Riobaldo - mesmo indagando se sua vida teve mesmo meio-do-caminho (GSV, p. 325) - há pelo menos uma certeza: a mediação de Deus, a onipresença do Uno em todas as coisas. Mas, talvez, haja outra certeza em Rosa, presente em tantas de suas estórias e que ecoa e reverbera na narrativa de Riobaldo: a certeza platônica de que se deve evitar as águas do rio Letes, águas do esquecimento. Esquecimento que significa ignorância, a pior das enfermidades, a pior das mortes. Por isso a tão antiga devoção dos gregos às Musas, por isso a afirmação sertaneja de que água limpa é nas cabeceiras, por isso se conta e se canta estórias, para se compreender melhor a - tão divina - comédia humana que é a própria vida. Por isso Riobaldo afirma que, para ele, esquecer é quase igual a perder dinheiro (GSV, p. 423) e oferece, à moda sertaneja do bem acolher, três dias de hospedagem para seu interlocutor viajante e lhe narra, de memória, de lembranças, sua estória - sua história.

Aqui, merecem nota alguns apontamentos de Roncari, em A canção de Siruiz, Ziruis, que ressaltam o intertexto da glosa de Riobaldo com o tema do início da Divina Comédia: "Nel mezzo del cammin di nostra vita/ mi ritrovai per una selva oscura,/ ché la diritta via era smarrita":

"O que a canção [de Siruiz] narrava era a comédia da sua própria vida [referindo-se à vida de Riobaldo], sendo a vila do Urubu a metáfora da "selva oscura" - "La selva è figura della vita terrena", diz Francesco de Sanctis ${ }^{148}$ - e a situação e a massa de lembranças e sentimentos do trecho referido [a glosa] descrevem como o herói se via: "ché la diritta via era smarrita". (2004: 81)

Vencer a "selva escura", figuração da vida terrena, é vencer o esquecimento, é combater a letal ignorância em busca do esclarecimento, da iluminação, da perdida e ardorosamente desejada "via direita" proposta pela Divina Comédia, de Dante Alighieri. Mas qual será a tão procurada "via direita" de Riobaldo? Prossigamos na hermética decifração da canção de Siruiz.

A segunda estrofe da canção, para um olhar menos meticuloso e atento, parece mais trivial, mais terraa-terra, apenas descrevendo e exaltando a paisagem, a natureza, os hábitos e o léxico do sertão ${ }^{149}$.

\section{Corro os dias nesses verdes, meu boi mocho baetão: \\ burití - água azulada, carnaúba - sal do chão...}

\footnotetext{
148 DE SANCTIS, Francesco. Opere, a cura de Nicolò Gallo. Milano-Napoli: Riccardo Ricciardi Editore, 1961, p. 156.

${ }^{149}$ ALBERGARIA, Consuelo, in op. cit., afirma que há, na canção de Siruiz, uma "predominância de semas que induzem a uma visão otimista e quase bucólica do sertão: 'alta/padroeira/verdes/água azulada/remanso/viola' que impregnam a canção de um tom pacífico, na realidade, bem diferente das atividades de Riobaldo, naquele cenário.” (1977: 97)
} 
Porém, basta um rememorar dos passos de Riobaldo, um reencontro com a glosa, para notarmos que não é bem assim, a ambivalência faz com que o aparente aprazível, na verdade, demonstre-se como um cenário muito perigoso, uma "selva oscura" cuja travessia requer muita coragem. Vejamos, no trecho glosado, o que o barranqueiro diz sobre essa estrofe:

Diadorim, os rios verdes. A lua, o luar: vejo esses vaqueiros que viajam a boiada, mediante o madrugar, com lua no céu, dia depois de dia. Pergunto coisas ao burití; e o que ele responde é: a coragem minha. Burití quer todo azul, e não se aparta de sua água-carece de espelho. Mestre não é quem sempre ensina, mas quem de repente aprende. (GSV, p. $325,326)$

O verde, é claro, vem dos olhos de Diadorim. Retomemos uma das descrições, dentre tantas, de Riobaldo para os olhos do(a) formoso(a) Diadorim: companheiro de batalha, companheira de coração, para endossar nossa proposição: Os olhos - vislumbre meu - que cresciam sem beira, dum verde dos outros verdes, como o de nenhum pasto. (GSV, p. 511). E, assim como Riobaldo se alimenta desses verdes - como o de nenhum pasto -, pasto também é o principal alimento dos bois e dos touros.

O boi, outro animal de predileção de Rosa, é onipresente em toda sua obra. E não poderia ser diferente, afinal é símbolo de integração nacional, cria de todos os cantos do Brasil - e do mundo -, além de alimento de todas as mesas, de todos os dias. Encontramos o boi tanto nas cantigas de ninar - como a tão famosa canção do boi da cara preta -, quanto nas modas de viola, tanto nos causos e lendas, quanto na literatura e nos textos científicos. Animal sagrado do presépio cristão que, contemplativo, testemunhou o nascimento de Jesus e que, na tradição religiosa indiana, de tão venerado, é até poupado do que, em outros países, é sua maior função. Boi da imolação purificadora entre os antigos gregos. Boi que serve de alimento, transporte, tração e que, em busca de pastos ou trânsitos, leva os homens em comitiva a se aventurarem no coração do sertão. Boi que, quando tranquilo a pastar, simboliza a bondade e a persistência, a força e a potência, além da capacidade de trabalhar e de, em silêncio, se sacrificar. Meu boi mocho baetão, como descreve o segundo verso, da segunda quadra, da canção de Siruiz, parecendo se referir ao próprio Riobaldo do começo até o meio - in medias res - de sua travessia: remansado jagunço movido apenas pela fome de pasto, pelo verde dos olhos de Diadorim, que, como aponta Moura, "acolhe a todas as reversibilidades de que o livro está repleto". E que, feito a Beatriz da Comédia de Dante, conduz o jagunço-poeta sertão - a ser tão - adentro.

Boi mocho é boi sem chifres, baetão é baeta grossa, cobertor de lã. Utéza interpreta o verso como a descrição de um "animal que não mostra nenhum sinal de agressividade - meu boi mocho; nem sequer tem realidade corporal - baetão -, parecendo um brinquedo de criança”. (1984: 270), mas, ao mesmo tempo, 
afirma que a quadra inteira representa o fato de o homem não estar sujeito ao escoar do tempo e ser, ao contrário, dono dele, "visto que é ele próprio quem determina o movimento temporal" (1994: 270): Corro os dias nestes verdes.

Logo, ficam latentes, novamente, nesses versos, as ambiguidades e as ambivalências típicas do romance: quem é o dono do escoar do tempo: o homem, o destino, Deus, o diabo? E no tempo de Riobaldo, quem é que manda se ele, o tempo todo, corre os dias nestes verdes..., se a canção de Siruiz, de fato, predisse e pressagiou suas erranças? Seria Riobaldo, com sua travessia profetizada pela canção, apenas um “brinquedo de criança” nas mãos do destino e de Diadorim - Diá, diabo, e Deodoros, "dom de Deus"? Seria ele, feito Jó, feito Fausto - o de Goethe (1808), o de Marlowe (1604) ou o de autoria anônima (1587) -, mais um títere, um instrumento de provação de fé, tendo os seus cordéis manuseados pelo Diá, pelo diabo, que, por sua vez, tem seus engonços manuseados pelo próprio Deus?... Só aos poucos é que o escuro é claro, talvez respondesse o próprio Riobaldo às nossas indagações.

E, para escurecer um pouco mais nossos passos, nosso itinerário rumo à tentativa de decifração da canção de Siruiz, vemos que outros importantes personagens de Grande sertão: veredas são também relacionados com a imagem do boi - ou do touro: Medeiro Vaz, quando morre, é cantado como meu boi preto mocangueiro, e, na glosa, Riobaldo, em cifras, explica: Medeiro Vaz morreu em pedra, como o touro sozinho berra feio; conforme já comparei uma vez: touro preto todo urrando no meio da tempestade (GSV, p. 326). Entretanto, como esclarece Reinaldo (2005: 156), o touro sozinho que berra feio, apontado neste trecho da sinuosa e mesclada explicação, não é Medeiro Vaz, ou não é apenas ele, mas Joca Ramiro: Joca Ramiro podia morrer? Como podiam ter matado? Aquilo era como se fosse um touro preto, sozinho surdo nos ermos do Guararavacã, urrando no meio da tempestade. Assim Joca Ramiro tinha morrido". (GSV, p. 312)

Noticiada poucas páginas antes da glosa que a compara e mistura com a de Medeiro Vaz, a morte de Joca Ramiro - no Guararavacã do Guacuí ${ }^{150}$, paraíso e inferno de Riobaldo, promessa de amor e de guerra em sua vida - era outra fronteira, outro sinal de mudança na vida do herói. A partir de então, não havia mais lugar para um boi mocho, baetão na estória - coisa, aliás, que Medeiro Vaz e Joca Ramiro, touros, ideais de virilidade e força na vida de Riobaldo, nunca foram nem quiseram que ele fosse.

\footnotetext{
150 Ainda tratando de outras alusões e referências à imagem do boi, em GSV, vale lembrar, aqui, como aponta UTÉZA que, "segundo contingências emocionais, no Grande sertão: veredas se afirma que na fazenda Boi-Preto tudo é ordem e beleza; só além do Brejo-Verde, tudo é informe e ameaçador". (1994: 229). Indo além de Utéza, a Fazenda "Boi-Preto", dum tal Eleotério Néves, lugar muito deleitável, no Guararavacã do Guacuí, é onde Riobaldo passou seus melhores momentos com Diadorim, quase - não fosse o anúncio da morte de Joca Ramiro -, declarando, ali, o seu amor pelo(a) companheiro(a). E Brejo-Verde - "o mais longe", muito após o "Chapadão do Urucúia - aonde tanto boi berra...” (p. 47) - parece fazer referência aos olhos de Diadorim e alusão às funestas consequências do final da história, aonde tanto [o] boi berra...
} 
E até o Hermógenes, assassino e traidor de Joca Ramiro, representação do mal que - feito a estória de Maria Mutema - de tão má gera o bem, também já fora tratado como boi na estória:

Assim eu figurava o Hermógenes: feito um boi que bate ${ }^{151}$. Mas, por estúrdio que resuma, eu, a bem dizer, dele não poitava raiva. Mire veja: ele fosse que nem uma parte da tarefa, para minhas proezas, um destaque entre minha boa frente e o Chapadão ${ }^{152}$. (GSV, p. 556)

Sendo assim, podemos afirmar que a metáfora do "boi", aliás, um dos animais de predileção do autor Guimarães Rosa, presente no segundo verso da segunda estrofe da canção de Siruiz, em harmonia de opostos, além de espelhar a própria aprendizagem de Riobaldo, mescla, mistura e aproxima todas as viris representações daqueles que, por admiração ou aversão, por simpatia ou rejeição, pelo bem e pelo mal, serviam-lhe, serviram-lhe e servir-lhe-iam de modelo, construíam, construíram e construiriam sua identidade.

E isso parece se comprovar mais tarde, quando o jagunço Riobaldo, seguindo os passos de seus arquétipos, deixa de ser um contemplativo boi mocho, baetão e se torna um homem de ação - mas, e ao mesmo tempo, como vale lembrar, sempre convidado por seu coração, também se tornando um lírico homem de letras e compondo os versos de suas próprias canções ${ }^{153}$. Após as mortes de Medeiro Vaz e de Joca Ramiro, o suposto pacto com o diabo e a destituição de Zé Bebelo da liderança dos jagunços contra o Hermógenes, Riobaldo, sentindo-se o "rei do sertão", o Urutu Branco ${ }^{154}$, decidido, afirma: Agora, o tempo de todas as doideiras estava livre para principiar (GSV, p. 455). E, ao complementar a canção de Siruiz, sinalizando com seus próprios versos as marcas de sua transformação, canta: em tempo de vaquejada/ todo boi é barbatão:/ deu doideira na boiada/ soltaram o Rei do Sertão...

\footnotetext{
${ }^{151}$ Em consulta ao Dicionário do Brasil Central, de O. Bariani, UTÉZA explica que o termo “boi”, em Goiás, significa Zinga com um gancho para atracar ou puxar a embarcação: "Este regionalismo parece esclarecer com nova luz a expressão 'feito boi que bate' - a vara que bate na água e faz avançar o barco." O mesmo Bariani diz: "remar, impulsionar a embarcação" - em nada atrapalha o curso do rio, pelo contrário, sua impulsão rítmica é necessária ao movimento." (1994: 184-185). Aqui se nota, mais uma vez, a lei de Aleixo, que afirma que mesmo o mal pode produzir o bem. Utéza e Albergaria traçam uma relação entre o nome Hermógenes com Hermes e Mercúrio. Para os antigos alquimistas, Mercúrio era uma espécie de solvente universal, que impedia a cristalização, a imobilidade. O Hermógenes, o boi preto, parece ser a sombra negra fundamental para temperar a travessia de Riobaldo e, feito a "Zinga", impulsioná-lo a seguir.

152 UTÉZA relaciona esse Chapadão com a "região atravessada pelo Urucuia no seu curso superior" (1994: 184) - essa informação será de relevante importância na nossa sequência da interpretação da canção que complementa a de Siruiz, feita pelo próprio Riobaldo, quando retomarmos a relação do nome próprio "Riobaldo" com o fluir das águas dos rios e, particularmente, das do rio Urucuia.

${ }^{153}$ Apolo, deus grego da aliança entre paixão e razão, símbolo da inspiração profética e artística, também tinha os seus bois, que lhe foram roubados por Hermes (Mercúrio, entre os romanos). Seu ardiloso irmão só foi perdoado do sacrílego furto ao lhe oferecer uma lira que inventara. Com a música, Hermes conseguira temperar a ira do irmão mais velho. Com a música, Riobaldo também tenta temperar suas emoções.

${ }^{154}$ MARTINS, Nilce Sant'Anna, in op. cit., aponta que Urutu, do tupi uru'tu, é uma cobra muito venenosa, uma jararaca-pintada (2008: 513). Riobaldo, porém, se torna um Urutú-Branco - nome que lhe deu o próprio Zé Bebelo, depois repetido por João Goanhá, antes de ir s'embora, tanger urubus, como o próprio respeitado mestre lhe explicara (p. 454) - e não uma jararaca ou um urutu pintado. Esse "branco" no nome de rebatismo - repetido em coro por todos os jagunços e que dava nova força ao Riobaldo para destituir, nesse exato momento, Zé Bebelo da liderança do bando, tomando o seu lugar - aparentemente não se dá à toa. Segundo CHEVALIER e GHEERBRANT, "assim como o negro, sua contracor [o branco] pode situar-se nas duas extremidades da gama cromática. Absoluto - e não tendo outras variações a não ser aquelas que vão do fosco ao brilhante - ele significa ora a ausência ora a soma das cores (...)” (2000: 141). Branco é, por isso, a cor da passagem nos ritos iniciáticos das mais diversas tradições religiosas: "cor privilegiada desses ritos, através dos quais se operam as mutações do ser, segundo o esquema clássico de toda iniciação: morte e renascimento." (2000: 141)
} 
Rosenfield, ao tratar da baldanza $a^{155}$ de Riobaldo e de seu inicial abandono passivo, feito um boi mocho, às experiências da vida e aos encantos de Diadorim - sentindo-se constantemente ameaçado por esse viver à deriva e seus perigos -, também trata das mutações do lírico e épico jagunço, e traz mais luz ao tom profético das canções do romance e de suas inter-relações:

Este perigo [de viver à deriva] concretiza-se de maneira dramática quando o agudo e invencível chefe Urutu Branco volta a ser "Riobaldo" na iminência do ataque inimigo. Prolongando os sonhos e devaneios envolvendo Diadorim, ele resolve tomar um banho no rio e, abandonado ao flutuar da água, é surpreendido pelo começo repentino da batalha. $\mathrm{O}$ mesmo chefe que se sentia, pouco tempo antes, infalível e triunfante, está agora sob o império diabólico do medo pânico (cf. a reversibilidade demo-medo): $\boldsymbol{E}$ eu acabei de me enroupar, mal mal, e escutava essas vozes: - Tu não vai lá, tu é doido? [...] O meu medo? (GSV, p. 439).

Como os fluxos e refluxos das ondas, também esta sensação de "horrorizância" cede de novo a uma atitude mais firme que permite a Riobaldo a volta à ação. Neste agir, revela-se, entretanto, a vaidade do querer e a ilusão do mando. Embora o chefe reassuma sua posição e postura de comandante, o narrador pergunta-se retrospectivamente: "Eu comandava?" (p. 440). Tudo se passa, com efeito, como se as respectivas posições se invertessem. Querendo proteger e poupar Diadorim, Urutu Branco é, na verdade, protegido e poupado por este. Adulando a soberbia do amigo, Diadorim consegue subtraí-lo ao perigo - e ao mando - do combate: Tu vai, Riobaldo. Acolá no alto, é que o lugar do chefe. (GSV, p. 441).

[...] É lá do alto que Riobaldo verá a queda e a morte de suas fantasias mais preciosas. Diadorim faz verter o destino da batalha, desafiando Hermógenes para o combate corpo-acorpo. Ele oferece assim ao chefe preso pela ilusão da sua própria valentia o espetáculo desolador do amigo e do inimigo mutuamente esfaqueados. (1992: 89-90)

Voltando aos baldos versos da canção original de Siruiz e às cifras do revelado caminho de ascensão de Riobaldo entre os jagunços, os dois versos finais da segunda estrofe descrevem, separadas mas em paridade, duas típicas palmeiras dos sertões de Minas: o buriti, relacionado com a água azulada, e a carnaúba, tratada como o "sal do chão". Vejamos o que a glosa diz a respeito:

(...) Pergunto coisas ao burití; e o que ele responde é: a coragem minha. Burití quer todo azul, e não se aparta de sua água - carece de espelho. (...) Zé Bebelo ia e voltava, como um uivo demais de fogo e vento, zás de raio veloz como o pensamento da ideia - mas a água e o chão não queriam saber dele (...) Assim era Joca Ramiro, tão diverso e reinante, que, mesmo em quando ainda parava vivo, era como se já estivesse constando de falecido. (...) Meu coração que entende, ajuda minha ideia a requerer e traçar. Ao que Joca Ramiro pousou que se desfez, enterrado lá no meio dos carnaubais, em chão arenoso salgado (...) (GSV, p. 326).

155 Termo usado por ROSENFIELD para tratar das oscilações emocionais de Riobaldo. Do italiano, baldanza significa audácia, coragem, imprudência. 
Sim, facilmente podemos associar as imagens das altas palmeiras sertanejas desses dois versos da canção de Siruiz aos entrecruzados dois maiores exemplos de coragem da travessia de Riobaldo: Medeiro Vaz e Joca Ramiro.

O verso Carnaúba - sal do chão foi ouvido, pela primeira vez, logo depois de o narrador de Grande sertão: veredas ter se impressionado com a também primeira visão do próprio Joca Ramiro, naquela madrugada de maio. Isto é, no exato momento em que, para Riobaldo, se apresenta o mais ilustre chefe dos jagunços, que lhe serviria de exemplo de virilidade, de coragem, de justiça e de conduta, ele também escuta as proféticas palavras de Siruiz, que destinariam ao "homem príncipe" - enterrado decerto, conforme cristão, num lugar não por acaso chamado Jerara, no meio dos carnaubais, em chão arenoso salgado (GSV, p. 313) - não a ordinária finitude e o esquecimento da morte, mas a instituição de uma nova lei, gerada pela necessidade de harmonia no sertão. "Sois o sal da terra", afirma Cristo a seus discípulos, no Sermão da Montanha, do Evangelho bíblico de Mateus. Joca Ramiro também seria o "sal da terra", ou o sal do chão, ideal de fé e de bons exemplos a serem seguidos, a não serem esquecidos.

Medeiro Vaz, quando morreu, teve seu corpo coberto com palmas de buriti novo, cortadas molhadas, e velado com uma vela de carnaúba, até ao quebrar da barra. Os entristecidos jagunços, em seu funeral, cantavam: Meu boi preto mocangueiro,/ árvore para te apresilhar? Palmeira que não debruça: buriti, sem entortar... (GSV, p. 96). Com a aurora, abriram-lhe uma funda cova nas terras boas dos Gerais. Ainda buriti novo, de palmas molhadas, não era o sal do chão, como Joca Ramiro, mas teve seu corpo, antes de ser devolvido à terra, iluminado pela cera da carnaúba, cera de palmeira mãe, árvore feminina que tudo dá - a cera, a palha, a madeira - e da qual, no sertão, todo homem se serve.

Se a canção de Siruiz representa Medeiro Vaz como a carnaúba, em Noites no sertão - outra das obras de Rosa, anterior ao Grande sertão: veredas, mas publicada no mesmo ano -, a palmeira que dá nome a um conto não é a carnaúba, mas o "Buriti" "156, que simboliza o poder fálico e a potência de Iô Liodoro: "força cabida, como a de uma árvore, para quem as mulheres abrem-se tal e qual as folhas do buriti”. Na geografia sertaneja, as águas azuladas das veredas servem de espelho e ajudam essa palmeira masculina, o buriti, espécie de arquétipo do sertão ${ }^{157}$, a ascender aos céus: Em toda vereda que se baixava, a gente saudava o buritizal e bebia a água, conta Riobaldo, ao narrar suas andanças pelos Gerais.

\footnotetext{
${ }^{156}$ ROSA, João Guimarães. Noites no sertão. Guimarães Rosa - Ficção completa. Vol. I. Rio de Janeiro: Nova Aguilar, 1994 , p. 863-988. 157 O buriti, como arquétipo do sertão, aparece em muitas das obras de Rosa. Em "Cara-de-Bronze", de Corpo de Baile, por exemplo, como acontece com a canção de Siruiz, o buriti serve de interlocutor para o violeiro João Fulano, cognominado Quantidades. Vejamos uma quadra de uma de suas canções: "Buriti, minha palmeira/ toda água vai olhar/ cruzo assim tantas veredas,/ alegre de te encontrar." (ROSA, 1967: 81). E, ainda no mesmo conto, o Grivo só começa a viagem "quando o coco do buriti madura em toda parte" (ROSA, 1967: 107). No sertão da caatinga, por fim, terras que o Grivo também atravessa, a vista da copa do buriti é que anuncia e antecipa ao viajante a mudança da paisagem: "Todo buriti é uma esperança." (ROSA, 1967: 109).
} 
O próprio Guimarães Rosa trata da importância do buriti para o sertão. Em carta a Bizzarri, descreve: "Nas veredas há sempre o buriti. De longe, a gente avista os buritis e já sabe: lá se encontra água." (BIZZARRI, 2003: 41)

Após tal explanação, não é preciso muito mais para se chegar à conclusão de que o potente buriti da canção representa Joca Ramiro, que, após morto, foi enterrado no meio dos carnaubais, em chão arenoso salgado. E, com os versos Burití - água azulada,/ carnaúba - sal do chão..., a profética canção de Siruiz, desde a sua primeira audição, saudava a ilustre chefia dos dois maiores mestres-jagunços do sertão - alturas de buritis e carnaúbas -, revelando já, na sua fatídica premonição, o cifrado destino nem um pouco aprazível ou bucólico que a saga do Grande sertão lhes reservava.

E - assim como o Grivo e o violeiro Quantidades de "Cara-de-Bronze" - do que pergunta ao buriti, Riobaldo recebe, por resposta, a coragem. E, por carecer de espelho, sabe que Burití quer todo azul, e não se aparta de sua água, como afirma na glosa. Sendo assim, prossegue espelhando-se em seus modelos perfilados de terra e de água, sem, contudo, se esquecer de um outro reflexo a se espelhar, um outro exemplo de conduta e de coragem: Zé Bebelo, homem de quem a água e o chão - Medeiro Vaz e Joca Ramiro - não queriam saber, mas que, indo e voltando como um uivo demais de fogo e vento, muito teve a ensinar sobre as elementares e complementares leis de água, terra, fogo e ar ao sertanejo Riobaldo.

No primeiro verso da terceira e última estrofe, novamente como num espelho, Riobaldo encontra outro retrato de si: o remanso de rio largo, imagem que, como já vimos, alude a seu nome e a seu destino: Riobaldo, rio largo de planície, de leito raso, meandroso, serpenteante, ora remansado, ora embravecido, sem muito rumo e traçados definidos, mas que busca nas suas dúvidas, no ser ou não ser - no ser e não ser -, nas suas falhas, frustrações e excessos - períodos de seca, vazante e cheia -, a audácia necessária para prosseguir e o desejo de se encontrar, consigo, com o outro, até o desembocar no mar - desembocar no mar? - pelas águas de um rio maior e mais potente, o São Francisco, deus fluvial do sertão, no qual, como seu afluente, se embarranca. Estrofe de decisão, de ação, de solidão, de amor, de devoção e de guerra.

\section{Remanso de rio largo, viola da solidão: quando vou p'ra dar batalha, convido meu coração}

Na glosa, Riobaldo, ao tratar da última quadra da canção de Siruiz, indaga a si e a seu interlocutor: 
Por que é que todos não se reúnem para sofrer e vencer juntos, de uma vez? Eu queria formar uma cidade da religião. Lá, nos confins do Chapadão, nas pontas do Urucúia. $O$ meu Urucúia vem, claro, entre escuros. Vem cair no São Francisco, rio capital. O São Francisco partiu minha vida em duas partes.” (GSV, p. 326)

Embora, como já apontamos, a crítica especializada aponte o rio São Francisco como o eixo, a espinha dorsal e o coração do sertão rosiano, e, com o encontro com o de-Janeiro, rio dos transes e trânsitos, tenha esse rio partido a vida do herói de Grande sertão: veredas em duas partes - como ele próprio afirma na glosa -, ao que tudo indica, para além da importância indiscutível do Velho Chico para o romance, parece que Riobaldo se identifica mesmo é com o rio Urucuia, claro, entre escuros, que, frustrado, baldo, mesmo em sua baldanza não deságua no mar, mas que volta ao pulsante São Francisco e, só então, assomando-se a ele, em una dualidade, encontra-se com o oceano.

Nos confins do Chapadão - segundo Viggiano, hoje nos municípios de Arinos e Buritis -, nas pontas do Urucuia, é onde Riobaldo gostaria de formar uma cidade da religião, para sofrer e vencer juntos, cidade onde todos, (re)ligados, pudessem se (re)unir, unos, feito o Urucuia e o São Francisco - feito o próprio Deus, Uno - numa terra compacta e densa de antigo paredão que só as águas podem mover e pelo qual só um rio pode se infiltrar.

A bacia hidrográfica do rio Urucuia nasce no alto da Serra Geral de Goiás, fronteira desse estado com Minas Gerais. Os córregos que formam suas nascentes estão nos municípios de Formosa e Cabeceiras, em Goiás, e Buritis, em Minas Gerais. O primeiro município mineiro, portanto, que bebe de suas águas, ainda em pequena quantidade, é chamado Buritis, nome, no plural, da árvore arquétipo do sertão de Rosa. Mais fortes e fortes, as águas do Urucuia vão deslizando entre morros e chapadões, no sentido Oeste-Leste, do poente ao nascente, passando por nove ${ }^{158}$ municípios mineiros - hoje, chamados Buritis, Formoso, Arinos, Uruana de

\footnotetext{
${ }^{158}$ Para HESÍODO, na Teogonia, nove dias e nove noites são a medida do tempo que separa o céu da terra e esta do inferno e nove são as Musas com seus poderes de presença e de presentificação. Para DANTE, em sua Comédia, no nono círculo do inferno, o dos traidores, é onde reside o próprio Lúcifer e, nesse círculo, no congelado Lago Cocite, todos os rios do inferno deságuam. Só a partir daí se sobe ao Monte do Purgatório. No Paraíso, também há nove esferas concêntricas que conduzem Dante, pelas mãos de Beatriz, ao Empíreo, o além da existência física. A nona esfera celeste, a Primum Móbile, última da existência física, provoca o movimento de todas as outras. MAZZARI, em "Figurações do 'mal' e do 'maligno' no Grande sertão: veredas", in: Revista de Estudos Avançados, v.22, n.64, 2008, p. 273-290, ao tratar da constante dúvida de Riobaldo sobre a existência ou não do Diabo e da primeira referência à figura de Quelemén de Góis, "que ajudará a deslocar a história narrada da trilha fáustico-demoníaca para a dimensão do aperfeiçoamento e da aprendizagem”, afirma: "Na visão do kardecista Quelemém, o que há mesmo são "baixos espíritos de terceira, fuzuando nas piores trevas e com ânsias de se travarem com os viventes" - encosto que terão dado nos nove nomes que, de Rincha-Mãe a Hermógenes, surgem soltos ao leitor e, ainda nas páginas iniciais, parecem soar-lhe como nova antecipação pressagiosa.". No Grande sertão: veredas, nove foram os dias necessários para Riobaldo e seu bando atravessarem o escampo dos infernos que era o Liso do Suçuarão (p. 524). Segundo CHEVALIER e GHEERBRANT, in op. cit., "sendo o último da série dos algarismos, o nove anuncia ao mesmo tempo um fim e um recomeço, isto é, uma transposição para um plano novo (...) a ideia de novo nascimento e de germinação, ao mesmo tempo em que a da morte; ideia cuja existência assinalamos em diversas culturas a propósito dos valores simbólicos deste número. Último dos números do universo manifestado, ele abre a fase das transmutações. Exprime o fim de um ciclo, o término de uma corrida, o fecho do círculo." (2000: 644)
} 
Minas, Riachinho, Urucuia, Bonfinópolis de Minas, Pintópolis e São Romão - até desembocar - ou embarrancar - no rio São Francisco e, com ele, ir ao encontro do mar.

O rio recebeu esse nome, Urucuia - que, em tupi, significa água vermelha, ou rio vermelho -, por conta do urucum, planta nativa da região, que produz, com suas sementes quando secas, uma tinta muito vermelha, usada pelos indígenas para pintar o corpo durante os ritos religiosos ou de guerra.

Na transição do outono para o inverno - no final do já tão citado e comentado mês de maio e começo de junho, por exemplo -, num remanso de rio largo, o Urucuia fica com suas águas claras e esverdeadas e, no verão, por conta do período chuvoso e em razão das enchentes, onde tudo se mistura, as águas ficam avermelhadas, da cor do barro. Barro, aliás, de que, segundo o Isaías bíblico (64:8), Deus é o oleiro.

O vermelho, como afirma Chevalier e Gheerbrant, no Dicionário de símbolos, é a cor que simboliza o princípio universal da vida, todavia esses mesmos autores, especialistas em símbolos, mitos e religiões comparadas, ressaltam as ambiguidades e o baldear dessa cor:

“(...) com sua força, seu poder e seu brilho, o vermelho, cor de fogo e de sangue, possui, entretanto, a mesma ambivalência simbólica destes últimos, conforme seja claro ou escuro. $\mathrm{O}$ vermelho claro, brilhante, centrífugo, é diurno, macho, tônico, incitando à ação, lançando, como um sol, seu brilho sobre todas as coisas, como uma força imensa e irredutível. O vermelho-escuro, bem ao contrário, é noturno, fêmea, secreto e, em última análise, centrípeto; representa não a expressão, mas o mistério da vida.” (2000: 944)

Ainda segundo Chevalier e Gheerbrant, para a antiga Alquimia clássica, fonte da qual, como vimos com os estudos de Sperber, Rosa muito se valeu, a "obra em vermelho", "cor do fogo central que brota do homem e da terra", "cor do atanor no qual se opera a digestão, o amadurecimento, a geração ou regeneração do homem e da obra", é que traria ao mundo o "homem universal". Para Utéza, assim como a "obra em vermelho da Alquimia", é o rio Urucuia, no Grande Sertão: veredas, que afasta a terra sertaneja do "caos telúrico" conjugado com o "caos humano":

“É o rio Urucuia que dá sentido a este caos. Ao longo de seu curso d'água, oriundo das altas terras do ocidente, surgem todas as manifestações de vida, desde a floresta virgem matricial até os embriões de cidades que são as grandes fazendas. Distribuidor das águas fecundantes, fonte energética, é o centro ativo à volta do qual a terra se torna fluida”. (1994: 66) 
Geograficamente, um dos lugares em que nasce o rio Urucuia é, ainda hoje, chamado de Raizama, e esse espaço físico, tratado como da-Raizama ${ }^{159}$ no romance Grande sertão: veredas, é assim descrito por Riobaldo, de modo quase metafísico, sem dono, logo no início de seu monólogo em forma de diálogo com o recém-chegado interlocutor - e também início do romance -, ao definir como dos "altos claros das Almas", a beleza desse lugar:

(...) rio despenha de lá num afã, espuma próspero, gruge; cada cachoeira, só tombos (...) Quem me ensinou a apreciar essas as belezas sem dono foi Diadorim... A da-Raizama, onde até os pássaros calculam o giro da lua... De em de, sempre, o Urucúia acima, o Urucúia tão a braba vai... Tanta serra, esconde a lua. (GSV, p. 42-43)

No aprendizado primevo de, bem próximo das nascentes do rio - fonte de todas as coisas -, apreciar, pelas mãos e olhos de Diadorim, as belezas sem dono - enquanto a serra esconde a lua, tal e qual a neblina escondia, no Reinaldo, a sua amada Diadorim e as neblinas de Siruiz velavam e revelavam seu cifrado destino -, o narrador prossegue, endossando o que mais nos interessa, sua identificação com o Urucuia: $\boldsymbol{O}$ senhor? Olhe: o rio Cariranha é preto, o Paracatú é moreno; meu, em belo, é o Urucúia - paz das águas... É vida! $(G S V$, p. 43)

O cenário e época desse aprendizado primeiro de vida, de paz das águas, é a fazenda Boi-Preto, no Guararavacã do Guacuí, altos do Urucuia ( $G S V$, p. 43), num fim de verão, de janeiro ou fevereiro ${ }^{160}$, tempo dos pendões de milho. Aí, Riobaldo narra que passou seus melhores momentos com Diadorim e, nas nascentes do Urucuia, como nas nascentes de si mesmo, conta que aprendeu também, com ela, a apreciar o canto dos pássaros (GSV, p. 44), afirmando, remansado - feito o que o Remanso do rio largo do verso da canção de Siruiz, tal um oráculo, antecipara -: Perto de muita água, tudo é feliz. (GSV, p. 45).

Após, Riobaldo irá sempre querer retornar ao que acreditava ser suas origens, as fontes e as cabeceiras do Urucuia, o da-Raizama, berço do canto dos pássaros: Aonde é que jagunço ia? À vã, à vã. Tinha minha vontade, de estar em toda a parte. Mas, quadrando que primeiro, mais para o norte: para o Chapadão do Urucúia, aonde tanto boi berra. Que eu recordava de ver o rio meu. (GSV, p. 47).

Entretanto, com as águas de $\operatorname{março~}^{161}$, o final de verão se transformaria em outono, inverno, e, novamente, em primavera e chuvoso verão. Após o muito trovejar, a revoada das tanajuras e uma tempestade

\footnotetext{
${ }^{159}$ Vale lembrar que o prefixo "A" pode ter sentido de negação e de privação, como em amoral (privado de moral). Raizama é uma palavra derivada de raizame, que significa conjunto de raízes de uma planta. A da-Raizama (de+a-Raizama) pode querer se referir a um lugar privado de raízes físicas.

${ }^{160}$ Da etimologia dos nomes dos meses, temos que o nome Janeiro, do romano Januarius, é uma homenagem ao deus Janus ou Jano que, como já denotamos neste estudo, é o deus das passagens e transições. Fevereiro vem de Februarius, do latim februus - em Roma, termo associado ao deus Plutão -, que significa "o que purifica, o purificador". No mês de fevereiro, realizavam-se, na antiguidade, cerimônias de purificação e ritos expiatórios.

${ }^{161} \mathrm{O}$ mês de março, do latim Martius, recebe esse nome em homenagem ao deus romano da guerra.
} 
torrencial, chegaria a notícia de que Joca Ramiro fora assassinado à traição pelo Hermógenes. O paraíso do Guararavacã do Guacuí, perdido paraíso, ficaria para trás, seria enterrado com o corpo do "homem príncipe". E o sertão se transformaria em inferno.

Com a estação das chuvas, o rio de águas claras e esverdeadas se tornaria vermelho turvo e embarreado, rio bravo, rio de perdição, rio com nome, Urucuia, como o dos versos que, mais tarde, Riobaldo, de autoria própria, oleiro de si mesmo, comporia. Copla feita de próprio coração e alma - essa última, aliás, que já nem tinha certeza se ainda era sua:

\section{Urucúia - rio bravo cantando à minha feição: é o dizer das claras águas que turvam na perdição.}

Logo no início da narração - nas primeiras páginas do romance, portanto - Riobaldo, unindo fim e começo, já nos alertava que, seguindo o curso do Urucuia, na margem esquerda do São Francisco e subindo em direção ao norte, num exato lugar, a serra fazia ponta e que, na encosta, brotava do chão um vapor de enxofre, com estúrdio barulhão, e o gado fugia de lá, por pavor... (GSV, p. 43).

Ainda que o gado fugisse de medo desse lugar, a continuação da narrativa nos revelaria que o curso das águas e das estações não possibilitaria a Riobaldo também fugir, ser um boi mocho, baetão por toda vida. A travessia pedia e imprimia, ao herói, a necessidade de decisão, de ação. A doideira na boiada, o suposto pacto e os versos feitos de próprio punho metamorfoseariam o outrora Tatarana, lagarta de fogo, num rei solto do sertão.

Mas, em meio aos reveses típicos da obra rosiana, se no lugar onde a serra faz ponta, as águas do Urucuia se turvam na perdição, Riobaldo faz questão de nos lembrar também de sua origem, lugar de onde veio e nasceu, localidade que, tal e qual a Raizama, do Urucuia, é paragem aprazível e feliz: (...) no sertãozinho de minha terra - baixo da ponta da Serra das Maravilhas, no entre essa e a serra dos Alegres, tapera dum sítio dito do Caramujo, atrás das fontes do Verde, o Verde que verte no Paracatú. (GSV, p. 58).

Fontes do rio Urucuia, fontes do homem Riobaldo, fontes do Verde como os olhos verdes da virgem Diadorim, de que o jagunço sempre bebeu e se alimentou, dos quais sempre correu atrás, os quais, do alto, verá se fecharem para nunca mais - para nunca mais?...

Verde feito a esmeralda, "orvalho de maio" 162 , que, para os alquimistas, era a representação exata de suas buscas, pedra de Hermes (de Mercúrio), o mensageiro dos deuses, do presenteado dom de Deus de se

162 Segundo CHEVALIER e GHEERBRANT, a esmeralda - também chamada de "orvalho de maio" - era, para os antigos alquimistas, "o símbolo do orvalho mercurial, do metal em fusão no momento em que, dentro da retorta, ele se transforma em vapor." (2000: 390). A esmeralda 
misturar entre homens e deuses, único que, como Deodoros ou Theódoros, tinha acesso ao Hades, regenerador e condutor das almas dos mortos.

Verde que, segundo o Dicionário dos símbolos, fazendo alusão a diversas religiões, mitos e tradições, é o "mediador entre o calor e o frio, o alto e o baixo, equidistante do azul celeste e do vermelho infernal ambos absolutos e inacessíveis.” E Chevalier e Gheerbrant complementam:

"Em todas as mitologias, as divindades verdes da primavera hibernam nos infernos, onde o vermelho ctoniano as regenera, por isso são exteriormente verdes e interiormente vermelhas, e seus domínios estendem-se por sobre os dois mundos. Osíris, o verde, foi despedaçado e jogado no Nilo. Ele ressuscita graças à magia de Ísis, a vermelha. É um Grande Iniciado, pois conhece o mistério da morte e do renascimento." (2000: 941)

Por fim, verde das águas do Urucuia no quase inverno de maio, depois do avermelhado das enchentes e cheias de março, e verde das veredas, sempre verdes, trilhas de boiadas e boiadeiros, tênues caminhos de penetração e de comunicação, berço das carnaúbas e buritis, reduto de pássaros, alimento dos rios, oásis que mantém vivos e redivivos o sertão e a faina sertaneja:

A Vereda recruza, reparte o plaino, de esguelha, da cabeceira-do-mato da Mata-Pequena para a casa-da-fazenda, e é alegrante verde, mas em curtas curvas, como no sucinto caminhar qualquer cobra faz. E tudo. O resto, céu e campo. Tão grandes, como quando vi, quando no fim: que ouvi só, no estradalhal, gritos e os relinchos: a muita poeira, de fugida, e os cavalos, se azulando. (GSV, p. 563)

O segundo verso da terceira quadra da canção de Siruiz - nome que, como já vimos, pode ser anagrama de Osíris, o verde, deus da morte e do renascimento, irmão e esposo ressuscitado de Ísis, a vermelha, deusa que tem em Sirius, sua estrela, astro que quando desponta junto com o poente indica a cheia do Nilo e a ressurreição da vida no deserto - parece representar, por fim, o canto e a influência dele, o encantamento do canto, sobre o próprio violeiro ao entoar sua canção, e sobre Riobaldo: viola da solidão.

Arroyo chama a nossa atenção para a importância das violas e violeiros no cenário sertanejo brasileiro e para o fato de que a viola é o único instrumento musical que figura na narrativa de Grande sertão: veredas, "sem qualquer preocupação de determinação característica, mas apenas a da alegria do seu som e de sua mágica tradição no interior do Brasil - instrumento dos homens, dos santos ${ }^{163}$ e do Diabo” (p. 205). E o estudioso de cultura popular prossegue:

que, segundo a tradição mítico cristã medieval, tombou da fronte de Lúcifer no momento de sua queda, representa a possibilidade de retorno ao Paraíso, de reconciliação com a Criação.

163 ARROYO (1984: 196-198) denota o tradicional culto fálico a São Gonçalo do Amarante, santo violeiro e casamenteiro, no Brasil. Trazido pelos colonizadores portugueses, o pesquisador afirma que mesmo em Portugal, "o culto das moças ao santo constitui um dos capítulos mais interessantes do comportamento religioso pelas suas implicações pagãs”. E explica:

O admirável em São Gonçalo é que ele tocava viola (daí a associação do instrumento musical a sua imagem) e assim convertia as mulheres,

"dançando com elas, alegremente, mas tendo nos sapatos pregos que o feriam nos pés" [Câmara Cascudo, Dicionário do Folclore 
As referências à viola na narrativa são numerosas, não só como expressão do sentimento musical de Riobaldo, mas também como reforço de suas ideias nas frases enunciadas. A viola em Riobaldo tem uma extensão metafórica e até o Diabo a sabe tocar. Desde logo, num episódio lírico com Diadorim, tranquila a natureza e suspensos os sobressaltos das andanças pelos Gerais, "como no tempo em que tudo era falante", acode a Riobaldo a primeira reflexão inserida nas imagens da viola: Só um bom tocador de viola é que podia remir a vivez de tudo aquilo. (GSV, p. 164) Aquilo aborrecia. Eu queria estar-estâncias: dos violeiros, que tocavam sentimento geral. (GSV, p. 191) (1984: 205)

Noutros vários momentos importantes da narrativa, a viola e os violeiros são retomados para reforçar as imagens, frases, crenças, sentimentos e ideias de Riobaldo. Como, por exemplo, no trecho da glosa em que o lírico jagunço se referia à sua compreensão do amor e comparava Diadorim com Otacília, evidenciando a capacidade desta de, diferentemente da primeira, forte como a paz, remansá-1o ${ }^{164}$ :

Só se pode viver perto do outro, e conhecer outra pessoa, sem perigo de ódio, se a gente tem amor. Qualquer amor já é um pouquinho de saúde, um descanso na loucura. Deus é o que me sabe. O Reinaldo era Diadorim - mas Diadorim era um sentimento meu. Diadorim e Otacília. Otacília sendo forte como a paz, feito aqueles largos remansos do Urucuia, mas que é rio de braveza. Ele está sempre longe. Sozinho. Ouvindo uma violinha tocar, o senhor se lembra dele. Uma musiquinha até que não podia ser mais dançada - só o debulhadinho de purezas, de virar-virar... Deus está em tudo - conforme a crença? (GSV, p. 327-328)

No sertão rosiano, assim como nas lendas e causos tradicionais dos interiores do Brasil ${ }^{165}$, é o toque da viola e as canções dos violeiros que dão o tom para o virar-virar da religiosidade, do amor e da guerra. E, se Deus está em tudo - conforme a crença?, em Grande sertão: veredas, tudo se remexendo, o Diabo também toca viola.

Brasileiro, p.776]. Já por demais conhecido é o culto da mulher solteira a São Gonçalo do Amarante. Isto dentro dos padrões normais do comportamento feminino, do respeito pela graça que pretende alcançar. O antigo culto, porém, chegou a acusar manifestações exacerbadas em tempos idos. Desses abusos, com frisos de erotomania guardou reminiscências uma quadra popular colhida no Baixo Douro por J. Leite de Vasconcelos: S. Gonçalo do Amarantel É feito de mel e azeite./ Dae-me lá na vossa cama/ Um logar d'onde me eu deite.

Na cidade do Porto, onde São Gonçalo do Amarante era orago da Sé, havia diante do altar do santo demorados bailaricos e canto de moças, inclusive de viúvas, em coro. Na igreja de São Domingos, na mesma cidade, a festa (10 de janeiro), a invocação e os pedidos ao santo eram piores, pois das reuniões participavam "todas as regateiras, principalmente as da Ribeira, e outras mulheres da mais baixa qualidade. As danças e as cantigas eram as mesmas; porém tal era a descompostura das ações, e a algazarra das vozes e alaridos, que as acompanhavam, que por indecorosas se teriam no meio de hum arraial, quanto mais dentro de hum templo sagrado!” [A. Tomás Pires, Investigações Etnográficas - Revista Lusitana, v. XII, p. 80]. O autor registra os versos entoados em coro nas duas igrejas: Casai-me, casai-me,/ São Gonçalinho,/ Que hei de resar-vos,/ Amigo santinho.

A exacerbação ao culto de São Gonçalo do Amarante, verdadeiro sincretismo religioso já na nova terra, passou para o Brasil conforme registros de alguns viajantes dos séculos XVII e XVIII (...) Em várias partes do Brasil ocorreram proibições das festas do dia 10 de janeiro.

164 Vide a comparação de Otacília com os largos remansos do Urucúia (...) que é rio de braveza na transcrição desse trecho da glosa. Retomaremos essas imagens na análise dos últimos versos criados por Riobaldo, em glosa incompleta, apresentados no final da narrativa por um bravo narrador-jagunço remansado.

${ }^{165}$ ARROYO (1984: 207-208) esclarece que a viola teve seu esplendor em Portugal no século XVI e, segundo a tradição, os soldados de D. Sebastião, desaparecido na batalha de Alcácer-Quibir, em 1578, teriam carregado para a África mais de cinco mil violas, que não chegavam ainda "para a saudade de todos os portugueses". Após, salienta que a viola portuguesa foi observada por Fernão Cardim, no Brasil, desde o século XVI. Citando a pesquisa de Alceu Maynard Araújo, Folclore Nacional, v. II, p. 449, afirma Arroyo: "De sua popularidade dizem bem dois fatos sugestivos: a intimidade do instrumento com São Gonçalo do Amarante e seus festejos e, para tocar bem a viola, chegar-se a "fazer pacto com o Diabo na sexta-feira santa". E conclui: "Riobaldo refletiu em seus anseios e inquietações a popularidade da viola". 
Já se crendo pactário, já supostamente sendo tentado, numa cena épica e lírica em que por pouco não matou nhô Constâncio Alves, um pobre viajante que atravessou seu caminho guerreiro, Riobaldo vê o demo tocando viola e multiplicando-se em inúmeros diabinhos, mil $\boldsymbol{e}$ mil, todos também empunhando suas violinhas:

Mas, aquilo de ruim-querer carecia de dividimento - e não tinha; o demo então era eu mesmo? Desordenei quase, de minhas ideias. Eu matava um tiquinho, só? Em nome de mim, eu não matava? Só forcejei por sobrenadar alto em mente o mando daquela vozinha. $R u$, eh, masquei meus beiços, eu arrebentasse. Vi que acabava tendo de matar, e era o que eu mesmo queria. Como que tivessem espalhado, ombro com ombro, pelos inteiros cabíveis do Chapadão, os diabinhos, mil e mil, tocando lindas violas - para acabar com o que eu mesmo me falasse, e de mim quisesse por valia me entender, contra o que o demônio-mestre tinha determinado... Sendo que mal resisti, nas últimas, saiba o senhor. Ah, mas. E é preciso, por aí, o senhor ver: quem é que era e que foi aquele jagunço Riobaldo! Pois em instantâneo eu achei a doçura de Deus: eu clamei pela Virgem... Agarrei tudo em escuros - mas sabendo de minha Nossa Senhora! O perfume do nome da Virgem perdura muito; às vezes dá saldos para uma vida inteira... (GSV, p. 487)

Arroyo analisa o encontro de Riobaldo com os "diabinhos tocadores de violas", tratando o entrecho como um "curioso caso de aproximação de extremos":

(...) a viola [no trecho transcrito] tanto se liga ao sagrado como ao demoníaco. Riobaldo não inventou, arbítrio seu, diabinhos tocadores de violas. A tradição do amor do Diabo por esse instrumento musical está registrada na superstição do povo. Manuel Querino, por exemplo, enumera uma crença na Bahia segundo a qual quando se ouve tocar viola alta noite, é o Demo que o está fazendo ${ }^{166}$. A paixão do Demônio pela viola chega a ser cínica, parecendo humana, conforme se verifica na lenda baiana fixada pelo mesmo autor. Em certa ocasião, num festejo de Nossa Senhora da Conceição, muitas pessoas se divertiam, "faltando, porém, um tocador de viola para animar o samba". Foram procurar um deles e encontraram, numa esquina, um rapaz tocando admiravelmente e que dizia chamar-se Sassaraneco. Participou ele cinicamente dos festejos, inclusive requestando mulatas. Mas lá às tantas um menino observou que Sassaraneco tinha os pés redondos e gritou alto a descoberta. O tocador de viola deu um grande estouro com forte fumarada e cheiro de enxofre e desapareceu. Era o Diabo. ${ }^{167}$ (ARROYO, p. 206-207)

Tendo em foco a ambivalente paridade dessa cena, com Riobaldo - feito os participantes dos festejos de Nossa Senhora, animados pelo violeiro Sassaraneco - entre o mando da vozinha do diabo e o perfume do nome da Virgem, merece transcrição a sequência imediata da glosa que diz respeito à relação de lírico-épico

\footnotetext{
${ }^{166}$ QUERINO, Manuel, A Bahia de Outrora, p. 95, Livraria Progresso Editora, Salvador, 1955.

167 ARROYO (1984: 207), apresenta ainda outra versão da relação tradicional entre o Diabo e a viola, nos interiores do Brasil: Em Cabelo Gordo, município de São Sebastião, a equipe da Comissão Paulista de Folclore recolheu versão da estória em que o Diabo transmite ao interessado seu virtuosismo na viola. Na versão existe um ritual a ser seguido: a viola tem que ser nova, sem uso algum, o dia tem que ser sexta-feira e o local uma encruzilhada, à meia-noite. Vem o Diabo, encontra a viola e põe-se a tocar lindas músicas. Deve haver luta entre o candidato a violeiro e o Demo, exigindo do primeiro grande sacrifício que é afinal recompensado com a fuga do Diabo que deixa todas as suas virtudes de violeiro com o candidato
} 
jagunço com suas crenças e amores, com Diadorim e Otacília, com Deus e o diabo, entre o bem e o mal, ouvindo uma violinha a tocar:

\begin{abstract}
Mas tudo vai vivendo demais, se remexendo. Deus estava mesmo vislumbrante era se tudo esbarrasse, por uma vez. Como é que se pode pensar toda hora nos novíssimos, a gente estando ocupado com estes negócios gerais? Tudo o que já foi, é o começo do que vai vir, toda a hora a gente está num cômpito. Eu penso é assim, na paridade. $O$ demônio na rua... Viver é muito perigoso; e não é não. (GSV, p. 328)
\end{abstract}

Finalmente, na última referência ao instrumento em Grande sertão: veredas, com os Hermógenes andando por bem longe e antes ainda do decisivo encontro no Paredão, Riobaldo trata das famosas violas de Queluz $^{168}$, hoje Conselheiro Lafaiete, em Minas Gerais, e de um momento de descanso na travessia:

Sossego traz desejos. Eu não lardeava; mas queria festa simples, achar um arraial bom, em feira-de-gado. Queria ouvir uma bela viola de Queluz, e o sapateado de pés dançando. [...] Devo redizer, eu queria delícias de mulher, isto para embelezar horas de vida. Mas eu escolhia - luxo de corpo e cara festiva. O que via com um desprezo era moça toda donzela, leiga do são-gonçalo-do-amarante, e mulher feiosa, muito mãe-de-família. (GSV, p. 540)

Nota-se, nesse trecho do romance, pela voz de Riobaldo, a exata manifestação do que Arroyo tratou como "verdadeiro culto fálico" a São Gonçalo do Amarante e à bela viola de Queluz. O jagunço guerreiro, já hipoteticamente pactário, entre o sagrado e o profano, em relação dialética - ou seguindo o "princípio da reversibilidade" denotado por Candido -, via com desprezo toda donzela leiga do são-gonçalo-do-amarante .

Com o vibrar das cordas da viola pelas mãos de São Gonçalo do Amarante, do Diabo e dos seus mil $\boldsymbol{e}$ mil diabinhos, de Siruiz, de Ludivino, de Luzié ou de um outro qualquer violeiro do sertão - tal e qual a lira presenteada por Hermes a Apolo que, por sua vez, foi dada de presente a seu filho Orfeu - e com os versos cantados na própria canção de Siruiz, a vida do solitário violeiro e do solitário jagunço movimentam-se em busca de suas procuradas e perdidas virgens, de suas procuradas e perdidas identidades, retomando-se, aparentemente, o mito grego de Orfeu e outros tantos mitos que têm as histórias de seus heróis vinculadas aos conteúdos e às propriedades mágicas da música, além da proximidade e distância, encontro e perda de suas amadas e dos rumos e sentidos de suas suscitadas e ressuscitadas travessias.

Os contatos com os cantadores Siruiz, Ludivino e Luzié - personagens que têm, na etimologia de seus nomes, a representação e a marca da luz -, ou com outras tantas personagens que cantam em Grande sertão: veredas, deixam Riobaldo desconfiado de que a vida do homem está presa encantoada. O poeta cantor é aquele que, como Orfeu fez com a nau Argo ${ }^{169}$, consegue tocar mesmo o mais duro e escurecido dos corações,

168 ARROYO (1984: 207) aponta que, no interior de Minas Gerais, "a viola famosa era mesmo a de Queluz [hoje, Conselheiro Lafaiete] que chegou a contar, em certa época, com quinze fábricas do instrumento".

169 No mito grego, Orfeu, filho da Musa Calíope e de Apolo, dos quais recebera a lira e o dom do canto, é o deus que apazigua e apascenta, com sua música, as feras, além de comover Caronte e o próprio Hades. Portador da lira de sete cordas, cada uma contendo uma feição da alma 
consegue mover, com sua música, mesmo aquilo que parece estar atracado aos rochedos, solidificado, cadenciando o ritmo e a vontade dos remadores rumo ao mar alto.

Em meio à espera angustiante e solitária da guerra, que deixava Riobaldo em nervosias, Luzié, cigarra de entre-chuvas, canta, cadenciando, órfico, a vontade dos guerreiros. O iluminado violeiro é aquele que cantava sem mágoas, sem lembranças dolorosas do passado ou angústias em face do futuro, sem se preocupar com o miúdo da vida. É para Luzié que Riobaldo pede que cante a canção de Siruiz.

Tanto que o inimigo não dava de vir, pois bem a gente ficava em nervosias. Alguns, não. Feito aquele Luzié [...] Às vezes, pedi que ele cantasse para mim os versos, os que não esqueci nunca, formal, a canção de Siruiz. Adiantes versos. (GSV, p. 260)

Se o sertão é o sozinho, como afirma a glosa, a (en)cantada viola da solidão é um alento, uma fonte revigorante e restauradora das forças ante a guerra e a solitária batalha que é a própria vida. E a canção de Siruiz, esses adiantes versos - versos que pareciam adiantar o que estava por vir -, assim como as demais canções entoadas por Luzié são momentos de esquecimento das dificuldades vividas pelos jagunços e pelo próprio Riobaldo. Canta-se pela expectativa do que está por vir. Canta-se para animar. Canta-se para louvar. Canta-se para espantar a solidão. O canto impede que o coração definhe, afasta as máculas e as mazelas da alma e da vida.

Em nome desse airar-se de alma, dessas pausas na batalha, desse entre-chuvas e dessa tentativa de se trazer algum esclarecimento para a "selva escura" em que se tornara a vida - de se buscar, nas cabeceiras do tempo, água limpa -, Riobaldo, ouvindo a viola de Luzié, num desejo súbito de brincar com os versos de suas canções, lembra-se de sua mãe e, com as saudades do amor materno, sente simultâneas saudades de Bigri e da matricial canção de Siruiz, misturadas: Minha mãe, ela era que podia ter cantado para mim aquilo. (GSV, p. 260)

Com o íntimo desejo de poder botar para se esquecer uma porção de coisas - as bestas coisas em que a gente no fazer e no nem pensar vive preso, só por precisão, mas sem fidalguia. (GSV, p. 260), o nostálgico jagunço - assim como o aedo inspirado e tocado pelas Musas de Hesíodo -, pelo encantamento do canto e pelo rememorar de coisas importantes, anseia por cura e liberdade, aspira, sob a égide de Mnemosine, a poder voltar atrás e fazer o mundo e o tempo retornarem à sua matriz original, ressurgindo com o vigor, a perfeição e a opulência de vida com que vieram pela primeira vez.

humana, Orfeu é aquele que tem acesso a um mundo diverso do dos seres vivos: o mundo inferior, visitado por ele para tentar trazer de volta da morte sua amada Eurídice, que está além do conhecimento humano. E não é outra, senão a música, o canal de acesso a essa dimensão suprahumana. Orfeu junta-se, ainda, aos Argonautas para que esses possam vencer o canto das Sereias. Na partida da Argo, a nau permanece imóvel, como que agrilhoada ou atracada aos rochedos. É Orfeu, com sua lira, que a move, fazendo imperar sua vontade e cadenciando o ritmo dos remadores. 
Riobaldo almeja vencer a "selva escura". E, sobre as lembranças que mais lhe valiam, nas obscuras horas que antecediam as batalhas, assim afirma:

Somente que me valessem, indas que só em breves e poucos, na idéia do sentir, uns lembrares e sustâncias. Os que, por exemplo, os seguintes eram: a cantiga de Siruiz, a Bigri minha mãe me ralhando; os buritis dos buritis - assim aos cachos; o existir de Diadorim, a bizarrice daquele pássaro galante: o manuelzinho-da-croa; a imagem de minha Nossa Senhora da Abadia, muito salvadora; os meninos pequenos, nuzinhos como os anjos não são, atrás das mulheres mães deles, que iam apanhar água na praia do Rio de São Francisco, com bilhas na rodilha, na cabeça, sem tempo para grandes tristezas; e a minha Otacília. (GSV, p. 533)

Recordando as mulheres mães e seus meninos pequenos, nuzinhos como os anjos não são, a apanhar água do São Francisco, sem tempo para grandes tristezas, em face das reminiscências da bizarrice do galante pássaro manuelzinho-da-croa, sempre em casal, machozinho e fêmea, o preferido de Diadorim ${ }^{170}$, e, em meio às memórias tantas, dos tantos femininos de sua vida - da canção de Siruiz à Bigri, das palmeiras de buriti a Diadorim e a Nossa Senhora de Abadia -, Riobaldo depara com essa outra saudade, esse outro desejo de voltar e essa outra lembrança, última recordação citada na transcrição, recordação essa que, em outro trecho da narrativa alinear, vem acompanhada de outros versos, aparentemente já de autoria do próprio cordial jagunço aspirante a aedo e cantor:

A saudade que me deu foi de Otacília. Moça que dava amor por mim, existia nas Serras dos Gerais - Buritis Altos, cabeceira de vereda - na Fazenda Santa Catarina. Me airei nela como a diguice de uma música, outra água eu provava. Otacília ela queria viver ou morrer comigo - que a gente se casasse. Saudade se susteve curta, desde uns versos:

Buriti, minha palmeira,

lá na vereda de lá:

casinha da banda esquerda, olhos de onda do mar...

Mas os olhos verdes sendo os de Diadorim. Meu amor de prata e meu amor de ouro. (GSV, p. 68)

A viola da solidão nos remete, aí, assim como no final da transcrição anterior, ao rememorar de Otacília, outra água de que Riobaldo provara, remanso de águas claras de que desejará mais e mais provar. Outra cabeceira de vereda, aliás, de outra vereda também, a de lá, a da banda esquerda, em harmonioso contraste e especular reflexo com a tão buscada "via direita" de sua travessia.

${ }^{170}$ (...) o manuelzinho-da-croa, sempre em casal, indo por cima da areia lisa, eles altas perninhas vermelhas, esteiadas muito atrás traseiras, desempinadinhos, peitudos, escrupulosos catando suas coisinhas para comer alimentação. Machozinho e fêmea - às vezes davam beijos de biquinquim - a galinholagem deles. - “É preciso olhar para esses com um todo carinho...”-o Reinaldo disse. (GSV, p. 159) 
Chegados à altura da barra do Urucuia, como localiza Viggiano, Riobaldo com mais quatro jagunços atravessaram, numa barca, o São Francisco e entraram pelo Urucuia adentro. Iam pela banda esquerda do rio do Chico para engrossar o bando de Medeiro Vaz e dar combate aos traidores. (VIGGIANO, 2007: 29). Foi nesse caminho, o da Fazenda Santa Catarina, num lugar chamado o Bom-Buriti, que o narrador do Grande sertão: veredas encontrou Otacília, minha palmeira, que queria viver ou morrer com ele e que se tornaria sua mulher e esposa depois de se aposentar da jagunçagem, após se (des)apartar de Diadorim.

Buriti - verde que afina e esveste, belimbeleza, descreve Riobaldo uma paisagem felizinha de aprazível dum lugar chamado o Bambual do Boi, onde Reinaldo veio lhe fazer companhia (GSV, p. 61). Diadorim, Diadorim, oh, ah, meus-buritizais levados de verdes... Buriti, do ouro da flor... (GSV, p. 614), lamenta o jagunço apaixonado, desesperado, a morte de sua dourada e adorada amada Diadorim. Se o buriti, palmeira alalã - pelas veredas, como já vimos, é uma referência para o sertão, sinal de vida, de água, de caminho, de coragem, e se Riobaldo parece ter perdido todas as suas referências com a morte de Diadorim, Buriti, do ouro da flor..., Otacília também é tratada, na canção pelo jagunço composta, como uma palmeira de buriti, minha palmeira de buriti, consoladora esperança possível em meio à aridez da vida e da morte sertanejas.

Carece de ter coragem... afirmou o Menino ao garoto baldo em sua primeira amedrontadora travessia, no de-Janeiro. Pergunto coisas ao buriti; e o que ele responde é: a coragem minha. Buriti quer todo azul, e não se aparta de sua água - carece de espelho, afirma a glosa do meio do Grande sertão a respeito das respostas dadas a Riobaldo pelos buritis, palmeiras que nunca lhe faltaram, arquétipos de líderes guerreiros, arquétipos do amor. Na diguice de uma música, nas águas do buriti, espelho delas - de Bigri, de Diadorim, de Otacília - e dele, Riobaldo, encontramos uma outra forma, outra tentativa de, pressagiando um destino funesto e procurando subverter o mito órfico, sem olhar para trás - sem olhar para trás? -, o jagunço-poeta poder um dia regressar, (re)encorajar-se, buscando, novamente, uma "matriz originária", um sentindo, uma nova canção, um canto de consolo e de remanso.

Todavia, de forma adversativa, Riobaldo lembrar-se-ia, por toda a vida, de que Otacília, seu amor de prata $^{171}$, tinha olhos de onda do mar - mar esse, aliás, no qual o rio Urucuia jamais desembocaria -, e que os olhos verdes, esses, seriam, sempre, de seu amor de ouro, Diadorim: Otacília sendo forte como a paz, feito aqueles largos remansos do Urucúia, mas que é um rio de braveza. Ele está sempre longe. Sozinho. Ouvindo uma violinha tocar, o senhor se lembra dele.” (GSV, p. 325). Riobaldo é o sozinho e, ouvindo uma

171 CHEVALIER \& GHEERBRANT (2000) denotam que tradicionalmente, por oposição ao ouro, que simbolicamente remete ao princípio ativo, masculino, solar, diurno, ígneo, a prata simboliza o princípio passivo, feminino, lunar, noturno, aquoso, frio. Na simbologia cristã, a prata representa a sabedoria divina, assim como o ouro evoca para os homens o amor divino. Para muitas crenças, esse metal representa a pureza. Para os bambaras, é um símbolo da água purificadora: Deus, que reúne os dois elementos purificadores fogo e água, é ao mesmo tempo ouro e prata." (p. 739-740). Em Grande sertão: veredas, Otacília é prata, Diadorim é ouro e Deus é, ao mesmo tempo, ouro e prata. 
viola tocar, a viola da solidão da canção de Siruiz, o senhor se lembra dele e todos nós, leitores, também sempre nos lembraremos.

Para finalizar esses primeiros passos na tentativa de decifração da canção de Siruiz, na navegação dos neblinados meandros de seus segredos, ainda embalados pela viola da solidão, temos os dois últimos versos da última quadra da balada: Quando vou p'ra dar batalha,/ convido meu coração, dos quais, aliás, já estamos há muito tratando. Esses, é claro, sintetizam a saga guerreira de Riobaldo e tratam daquilo que guiava a todo o tempo a vida e a natureza cordial - de coração - do lírico jagunço. Em última instância, o coração de alguém baldo, indeciso, incerto, que ainda não tinha se formado nem amadurecido o suficiente para escolher conscientemente e por vontade própria o seu destino, mas que já estava intuitivamente se preparando para a batalha e adivinhando a longa travessia que o aguardava, que o destino lhe reservava, e na qual não conseguiria se apartar do coração. E não estamos tratando apenas de seus amores da vida inteira, de Bigri, sua mãe, de seu amor de prata, Otacília, e de seu amor de ouro, Diadorim, dos quais nunca, de fato, conseguiu se apartar. Estamos tratando também da natureza de seus gestos, ideias, decisões, audácias, medos, sentimentos e de tudo isso misturado e passível de reversibilidade.

Com minha brandura, alegre que eu matava. (GSV, p. 35), comentou Riobaldo, logo no começo da narrativa, tratando do que seria capaz de fazer - e com alegria - com o sanguinário delegado Jazevedão, afirmando, contudo, ao seu erudito interlocutor calado não saber se ele, de fora, de longe, seria capaz de entender as leis do sertão:

(...) o senhor nem tem calo em coração para poder me escutar. [Jazevedão] conseguiu de muito homem e mulher chorar sangue, por este simples universozinho nosso aqui. Sertão. $O$ senhor sabe: sertão é onde manda quem é forte, com as astúcias. Deus mesmo, quando vier, que venha armado! E bala é um pedacinhozinho de metal... (GSV, p. 35)

E Riobaldo, de princípio, talvez também não soubesse dessas leis sertanejas e só a pouco e pouco, com brandura guerreira, é que, ele próprio, em sua própria cruzada, fora aprendendo, compreendendo, e, com isso, ficando mais e mais forte, com as astúcias. Todavia, sempre tomando, por guia, o seu coração.

Crendice? Mas coração não é meio destino?, indagou-se, no dia em que começou a questionar a capacidade de liderança de Zé Bebelo, por conta do medo que o até então intrépido líder sentiu no Sucruiú. Medo da bexiga, do risco de doença e de morte: achando que o povo do Sucruiú podiam ter trazido o mauar, e que mesmo o Sucruiú ainda demeava vizinho justo demais. (GSV, p. 416) 
Enquanto o grande Zé Bebelo pegava a principiar medo, Riobaldo, seguindo seu "coração adivinhador" ${ }^{172}$, se ria:

Tanto ri. Mas ri por de dentro, e procedi sério feito um pau do campo. [...] o cabedal é um só, do misturado viver de todos, que mal vareia, e as coisas cumprem norma. Alguém estiver com medo, por exemplo, próximo, o medo dele quer logo passar para o senhor; mas, se o senhor firme aguentar de não temer, de jeito nenhum, a coragem sua redobra e tresdobra, que até espanta. Pois Zé Bebelo, que sempre se suprira certo de si, tendo tudo por seguro, agora bambeava. Eu comecei a tremeluzir em mim. (GSV, p. 416)

Isso, não pensei - mas meu coração pensava. Eu não era o do certo: eu era o da sina! (GSV, p. 522) - afirma ainda Riobaldo, noutro trecho do Grande sertão, denotando o quanto, tantas vezes, era o seu coração que pensava por ele, e que era a sua sina de ir pra dar batalha carregando o coração aquilo que mais o definia, o definiria e lhe traria coragem. Aquilo que mais, ainda hoje, define esse narrador-rio em sua épica e lírica travessia. E, no desejo de decifrar as coisas que são importantes, seguindo a sina que o levava a tremeluzir e respeitando os aprendizados de Siruiz e as leis do sertão, esse coração lhe pediu que vertesse em versos a matéria vertente de sua sina. E Riobaldo se tornou um bardo sertanejo e começou a compor suas próprias canções.

\footnotetext{
172 ARROYO (1984: 141) denomina como “coração adivinhador" a "capacidade de o coração adivinhar as coisas e até mesmo de pensar” referida por Riobaldo em vários momentos de Grande sertão: veredas. O pesquisador aponta que Rosa, pela voz de Riobaldo, faz eco à crendice e superstições populares que existem no Brasil desde os tempos de sua colonização e que poderiam trazer consigo uma antecipação de métodos psicológicos de mergulho na subjetividade e na psique em busca de esclarecimentos e de redirecionamento de ações visando a um futuro mais aprazível, um remanso de rio largo.
} 


\title{
DA MATÉRIA VERTENTE ÀS VERTENTES DO VIVER
}

Não gosto de me esquecer de coisa nenhuma. Esquecer, para mim, é quase igual a perder dinheiro.

\author{
(Grande sertão: veredas, Guimarães Rosa) ${ }^{173}$
}

Muito já tratamos das angústias, frustrações e dos desejos sublimados do cordial Riobaldo Tatarana em face de seus ambíguos e ambivalentes sentimentos pelo seu amado, amigo e companheiro, a donzela-guerreira Reinaldo Diadorim. Muito já tratamos também dos passos e atos não menos sublimados desse herói jagunço que se manifesta como uma espécie de Parsifal sertanejo em sua elevada demanda por respostas e em seu empenho pela restauração de um "reino decadente" 174 alegorizado na própria árida e violenta realidade guerreira que o rodeia. Agora, mesmo tendo em mente que, pelo constante "princípio da reversibilidade" preconizado por Candido, tudo se mistura na voz e na vida do narrador épico-lírico do Grande sertão: veredas, em busca da decifração dos versos que o próprio cordial jagunço, aprendiz de aedo e de cantor, inspirado nas quadras de Siruiz, compôs, abordemos um pouco também de seus anseios, desígnios e amores mais denotativamente físicos, mais concretamente possíveis, tangíveis, menos neblinados e platônicos. E começaremos tratando dos desejos encarnados, materializados e saciados nas mulheres dos caminhos.

$\mathrm{Na}$ glosa do meio do romance, Riobaldo assim se refere aos seus muitos e misturados convites ao coração - convites esses, aliás, com os quais finaliza a canção de Siruiz:

\begin{abstract}
Diadorim me veio, de meu não-saber e querer. Diadorim - eu adivinhava. Sonhei mal? E em Otacília eu sempre muito pensei: tanto que eu via as baronesas amarasmeando no rio em vidro - jericó, e os lírios todos, os lírios-do-brejo - copos-de-leite, lágrimas-de-moça, são-josés. Mas, Otacília, era como se para mim ela estivesse no camarim, do Santíssimo. A Nhorinhá - nas Aroeirinhas - filha de Ana Duzuza. Ah, não era rejeitã... Ela quis me salvar? De dentro das águas mais clareadas, aí tem um sapo roncador. Nonada! A mais, com aquela grandeza, a singeleza: Nhorinhá puta e bela. E ela rebrilhava, para mim, feito itamotinga $^{175}$. Uns talismãs. A mocinha Miosótis? Não. A Rosa'uarda. Me alembrei dela; todas as minhas lembranças eu queria comigo. (GSV, p. 326-327)
\end{abstract}

Analisando as cifradas linhas dessa glosa, relembramos que Diadorim, como já vimos e tanto tratamos, é o não-saber e querer de Riobaldo, desejo sublimado no mirar e não ver de toda a sua travessia.

\footnotetext{
${ }^{173}$ Grande Sertão: Veredas. 19a ed. Rio de Janeiro: Nova Fronteira, 2001, p. 423.

${ }^{174}$ PATIER, A. R. Schmidt, in prefácio a ESCHENBACH, Wolfram von. Parsifal. $3^{\text {a }}$ edição. São Paulo: Editora Antroposófica: 2006, usa esses termos para tratar da restauradora missão de Parsifal na demanda do Graal.

${ }^{175}$ MARTINS (2006: 279) denota que Itamotinga é uma variedade de pedra brilhante que se encontra nas margens dos rios. Do tupi itamo'tina, pedra branca.
} 
Otacília, baronesa ${ }^{176}$ amarasmeando no rio em vidro, campânula redentora e consoladora em face de um sertão decadente, mesmo em meio ao popularmente afrodisíaco jericó - também chamado de ressurreição -, é o alvo lírio-do-brejo, o branco copo-de-leite, a cândida lágrima-de-moça, o ebúrneo são-josé - este último também conhecido como lírio do cajado de São José -, todas flores sertanejas, as mais claras e sublimes, todas de brejos e águas calmas e paradas, todas decorando o camarim, do Santíssimo, no qual Riobaldo - ou uma parte de si que se manifesta como um Urucuia em redoma, rio envidraçado, apático, com desejo de serenar - colocara, em suspensão, aquela que seria sua futura esposa, acessível mas distante, luzeiro em meio à neblina, último - sublimado - porto a se ancorar, aquela que remansaria - remansaria? - suas baldas e tormentosas, turvas águas urucuianas.

Mas, dentre as mulheres que marcaram sua travessia até Otacília, havia também a Nhorinhá, filha da filha de ciganos Ana Duzuza - dona adivinhadora da boa ou má sorte da gente -, a puta e bela Nhorinhá, das Aroeirinhas $^{177}$. E era pensando nela que Riobaldo se questionava se, como um talismã ou como uma esbranquiçada itamotinga ${ }^{178}$, alva pedra que só se encontra nas margens dos rios, quereria e poderia, feito um talismã, salvá-lo.

De dentro das águas mais clareadas, aí tem um sapo roncador (GSV, p. 326-327), alertava o jagunço, a si mesmo, ao falar de Nhorinhá, comparando-a com seus outros claros, alvos, altos - e perigosos, imprevistos e imprevisíveis como o sapo roncador - amores de prata e de ouro que tanto dele demandavam, e que tanto lhe faziam sofrer.

Ah, a mangaba boa só se colhe já caída no chão, de baixo... (GSV, p. 49), referia-se, Riobaldo, ao amor de colheita simples, de tanto afeto e bem-querer, que tinha em Nhorinhá. Amor com gosto de mangaba, que recebera por presente sem nada pedir em troca. E prosseguia o lírico narrador jagunço a descrever os encantos tão fáceis de se nomear, tão sem-mesquinhice, tão avessos à confusão, tão diferentes em tudo dos de Diadorim, que colhia da prostitutriz: Ah, a flor do amor tem muitos nomes. Nhorinhá prostituta, pimentabranca, boca cheirosa, o bafo de menino-pequeno. Confusa é a vida da gente; como esse rio meu Urucúia vai se levar no mar. (GSV, p. 206).

Nhorinhá, pedra colhida na beira do rio, fruta madura caída no chão, delicado talismã, de quem Diadorim tinha tanto ciúme, de quem a donzela-guerreira falava com tanta mágoa, confundindo, inclusive, o

\footnotetext{
${ }^{176}$ Baronesa, além de referir-se à mulher que tem um título de baronato, é o nome de uma ninfeácea - uma planta aquática de flor branca ou azul, também chamada nos interiores do Brasil de dama do lago - que desce das lagoas para os rios no período das cheias de inverno. O lótus, que produz uma flor de beleza sublime e muito venerada no oriente e que, por desabrochar sobre águas paradas e turvas simboliza expansão e elevação espiritual, também é uma ninfeácea.

177 Árvore também chamada de aroeira-vermelha, devido aos seus frutos carmesins, de cor vermelha bem forte e brilhante, conhecida ainda como falsa pimenta.

${ }^{178}$ Nhorinhá puta e bela. E ela rebrilhava, para mim, feito itamotinga. Uns talismãs. (GSV, p. 327).
} 
local de morada da terna prostitutriz preferida por Riobaldo, tratando por Rama-de-ouro ${ }^{179}$ o que Aroeirinha era. Talvez, em seu ato falho, Diadorim vislumbrasse possibilidades, sentisse que poderia ser a formosa meretriz, jamais esquecida por Riobaldo e também por Diadorim, a única capaz de evitar tanta confusão na vida de seu amigo e amado companheiro jagunço, capaz de trazê-lo de volta, tal um "ramo-de-ouro" dos labirintos infernais:

- “... Ou quem sabe você resolve melhor mandar de dádiva para aquela mulherzinha especial, a da Rama-de-Ouro, filha da feiticeira... Arte que essa mais serve, Riobaldo, ela faz o gozo do mundo, dá açúcar e sal a todo passante...”

Não era na Rama-de-Ouro - era na Aroeirinha. Mas, por que era que ele falava no nome de Nhorinhá, com tão cravável lembrança? Ao crer, que soubesse mais do que eu mesmo o que eu produzia no coração, o encoberto e o esquecido. Nhorinhá -florzinha amarela do chão, que diz: - Eu sou bonita!... E tudo neste mundo podia ser beleza, mas Diadorim escolhia era o ódio. Por isso era que eu gostava dele em paz? No não: gostava por destino, fosse do antigo do ser, donde vem a conta dos prazeres e sofrimentos. Igual gostava de Nhorinhá - a sem-mesquinhice, para todos formosa, de saia cor-de-limão, prostitutriz. Só que, de que gostava de Nhorinhá, eu ainda não sabia, filha de Ana Duzuza. (GSV, p. 392393).

Assim Utéza descreve Nhorinhá, na confusão de Diadorim a respeito das origens e local de morada da prostitutriz, e trata da importância da jovem e formosa "mulher-dama" para o Grande sertão: veredas e para a travessia de Riobaldo:

O mundo inteiro encontra a felicidade junto dela, sob a forma da harmonia dos contrários açúcar e sal. Nestas condições a confusão entre Aroeirinha e Rama-de-ouro adquire outro relevo. Na medida em que a substituição de uma palavra por outra resulta do subconsciente, para a mulher-jagunço, Nhorinhá certamente se relacionava com aquele Ramo de ouro que os adeptos anelam possuir.

Mas, para o alcançar, é preciso passar por transmutações do tipo daquela que vivem os hóspedes das mulheres-damas do Verde-Alecrim. (1994: 337)

Nhorinhá talvez pudesse mesmo ser a da Rama-de-ouro de Riobaldo se a carta que mandara ao seu adepto não tivesse demorado oito anos para chegar, zanzando pelo sertão até encontrar o cavaleiro-jagunço já casado com Otacília. Mas a carta, como afirmamos, não chegou ou demorou demais. Riobaldo abriu mão de sua rama-de-ouro - daquilo que produzira encoberto e esquecido no coração e de quem Diadorim podia saber mesmo mais até do que ele - e, em prata, remansou.

Havia ainda a mocinha Miosótis ${ }^{180}$ - nome originado de uma flor de coloração azul, também chamada, nos interiores do Brasil e em algumas regiões da Europa, de "não-me-esqueças", conhecida na tradição

\footnotetext{
${ }^{179}$ UTÉZA (1994:335) relembra que o "Ramo de ouro" é “a prenda que Enéias deve trazer para Prosérpina, a chave que a Sibila de Cumes indica ao herói troiano no Canto IV da Eneida para ele poder descer aos Infernos e regressar".

${ }^{180}$ Uma lenda do interior de Minas Gerais narra que Nossa Senhora, indo ao encontro de Jesus, após muito tempo sem ver o filho, passou por uma campina estrelada de minúsculas florezinhas brancas. Aí, quedou-se a contemplá-las com imensa ternura e, dos seus olhos cor do céu, caíram lágrimas de saudades. As lágrimas da Virgem orvalharam as pétalas das pequeninas flores alvas que, desde então, tomaram a cor dos olhos de
} 
popular como a flor da recordação, da fidelidade, do amor verdadeiro -, que, à parva, à tantice, menina bobinha, tinha sido, ainda nos tempos da São Gregório, namorada de Riobaldo e refúgio e guarida de sua juventude. Terno passado de um baldo rio ainda próximo da nascente que, todavia, feito flor de destino incerto boiando na correnteza, as águas do tempo levariam e deixariam para trás, mas não sem, antes, mostrar as meândricas importâncias do fluir e o valor do rememorar. Miosótis sempre lembraria a Riobaldo, aliás como Mnemosine às suas filhas, o quão caro a ele era o não se esquecer.

E, por fim, havia a Rosa'uarda ${ }^{181}$, primeira experiência sexual do menino, primeira aprendizagem amorosa do homem, antes ainda de ele sequer imaginar os rumos a que levaria - aos quais seria levado - em sua travessia de jagunçagem e de narrador. Rosa'uarda foi a primeira parada do órfão Riobaldo após a partida em explosão da fazenda São Gregório, com a descoberta de que Selorico Mendes era, na verdade, seu pai. Todavia, prometida a um turco, a amante-mãe não pode oferecer abrigo ao edípico jovem baldo.

O herói de Grande sertão: veredas, quando vai p'ra dar batalha, não vai mesmo apenas como um matador e justiceiro, guerreando pelo sertão feito outros tantos jagunços companheiros seus, nem tão pouco segue só como um nostálgico e melancólico cavaleiro solitário em demanda por seu Graal, sublimando seus amores e desejos carnais em busca de um ideal purificador, de um religar-se com o perdido e o esquecido, fazendo de sua vida apenas um rito iniciático, uma cruzada e um caminho de ascese.

Riobaldo carrega consigo, cordial, todas as suas lembranças, todos os seus amores, todas as suas mulheres, todas as suas dores, todos os seus desejos e desígnios - recalcados ou não, sublimados ou não -, todos os seus demos e medos, e a batalha não é apenas contra o inimigo ou com o Hermógenes, com Deus ou contra o diabo, a batalha é consigo mesmo: ele quer saber o sentido das coisas, quer explicações para os fatos e atos da vida e da morte, quer entender o verdadeiro significado do mundo e das tão ambíguas e ambivalentes coisas do mundo. Pergunta sobre seu amor por Diadorim. Pergunta sobre seu amor por Nhorinhá. Pergunta sobre seu amor por Otacília. Pergunta de quem é ou deve ser seu coração. Pergunta se o diabo existe e se fez o pacto com ele. Pergunta se sua alma é dele, do diabo ou de Deus, e se poderia ter sido salvo de seu destino ou se conseguiria ter salvado Diadorim do dela. Indaga sobre sua culpa, sobre as razões e sem-razões de Deus,

\footnotetext{
Maria e azuis ficaram para todo o sempre. Essas flores receberam o nome de miosótis. Uma antiga lenda alemã diz que dois jovens noivos passeavam à beira do Danúbio, quando viram uma florzinha azul celeste boiando na corrente. A moça lamentou o destino da flor e o rapaz, tentando apanhá-la, caiu na água. Num derradeiro esforço, pegou essa flor e atirou-a à noiva, gritando as comoventes palavras: vergissmeinnicht. Era como se suplicasse: não te esqueças de mim! Na Inglaterra, a miosótis tem o nome de forget me not. (GOMES, Lindolfo. Contos Populares. Dias Cardoso \& Cia. Editora, Juiz de Fora, 1918)

${ }^{181}$ O “'uarda" de Rosa'uarda pode ter origem germânica em ward, que significa "guardião ou protetor", da qual resulta "guardiã ou protetora da Rosa”. De CHEVALIER e GHEERBRANT, op. cit. p. 788 a 790, vemos que, dentre uma vasta gama de significações simbólicas, a rosa representa a "manifestação oriunda das águas primordiais, sobre as quais se eleva e desabrocha (...) referência à beleza da Mãe divina". Símbolo de renascimento, denota o Dicionário de Símbolos, citando Mircéa Eliade: "Sobre o campo de batalha em que caíram numerosos heróis, crescem roseiras e roseiras bravas. Rosas e anêmonas saíram do sangue de Adônis, enquanto o jovem deus agonizava. É preciso que a vida humana se consuma completamente, para esgotar todas as possibilidades de criação ou de manifestação; se vem a ser interrompida bruscamente, por uma morte violenta, tenta prolongar-se sob uma outra forma: planta, flor, fruta." (Traité d'histoire des religions. Paris, 1949; nova edição 1964).
} 
do diabo, de Diadorim, do amor e dos homens e se são válidas as explicações de seu compadre espírita Quelemén.

Mas Riobaldo se diz um homem ignorante e parece gostar de sê-lo - ou de aparentar sê-lo. A gente só sabe bem aquilo que não entende (GSV, p. 138), afirma e reafirma, reiteradamente, ao seu calado interlocutor-doutor e a si mesmo as formas e modos de sua suposta e conveniente - conveniente? - ignorância.

Sem querer fazer uso apenas do saber analítico e racional, a "megera cartesiana” que separa, divide, dissocia, o narrador do Grande sertão: veredas - assim como o autor do romance - quer o saber intuitivo e sinestésico dos recadeiros e de Laudelim Pulgapé, de "O recado do morro", quer o saber das coplas do violeiro Quantidades e da poesia do Grivo, de "Cara-de-bronze", quer saber bem daquilo que não entende, quer o saber de conquistada autoridade de Joca Ramiro e de Medeiro Vaz, o saber prático de Zé Bebelo, o saber místico de Siruiz, o saber sensual, físico e natural de Nhorinhá ${ }^{182}$, o saber tranquilizador de Quelemén, e quer ver a lume da lua, a ponto de, após, tentar também ele, como afirmamos ao final do capítulo anterior deste estudo, tornar-se poeta e cantor - um “cantador” encantado, inclusive, pela própria dor que lhe propicia o canto -, um cavaleiro trovador, um aedo sertanejo em busca dos mistérios que apenas a música poderia, a lume da lua, quebrando barras, lumiar e aclarar.

Se Riobaldo afirma que os versos por ele compostos, gôros, remidos, esses seus aparentes primeiros versos, não deram cinza e morreram, e que ele não se lembra de nenhum deles, de memória, mesmo assim, vencendo Lete, o esquecimento, consegue, tal e qual os aedos inspirados pelas musas teogônicas, reproduzir a seu interlocutor-forasteiro três trechos de canções suas - dois com três quadras e um, aparentemente incompleto, com apenas um dístico -, versos esses retomando o mesmo esquema rítmico e métrico da canção de Siruiz e das mais antigas "quadras sertanejas"183, como dando sequência à original e primeira, primeva canção, ouvida ainda em menino na orvalhada noite de maio da fazenda São Gregório.

O Riobaldo aspirante a bardo, agora, para além de predizer a sua vida, do outro para si, decifrando com a canção de Siruiz o seu destinado e desatinado caminho, colocava, ao que tudo indica, com os versos seus, escritos de próprio punho e de memória, as rédeas dela, da própria vida, da própria sina, em suas mãos, vencendo, ao menos pontualmente, como afirma Candido em "O homem dos avessos", a ambiguidade do

\footnotetext{
${ }^{182}$ Se chamava Nhorinhá. Recebeu meu carinho no cetim do pêlo - alegria que foi, feito casamento, esponsal. [...] Depois ela me deu de presente uma presa de jacaré, para traspassar no chapéu, com talento contra mordida de cobra; e me mostrou para beijar uma estampa de santa, dita meia milagrosa. Muito foi. (GSV, p. 49)

${ }^{183}$ CASCUDO, Luís da Câmara, in Vaqueiros e cantadores. São Paulo: Global, 2005, explica que os versos sertanejos mais antigos eram as chamadas "quadras":

Diziam-nos [os sertanejos] "verso de quatro". Subentendia-se "pés" que para o sertanejo não é a acentuação métrica mas a linha. Essa acepção ainda é portuguesa. "Um pé de verso e outro de cantiga", escrevia Frei Lucas de Santa Catarina (1660) no "Anatômico Jocoso" (p. 54 da edição resumida da Cia. Nacional Editora, Lisboa, 1889). Em quadras (ABCB) foram todos os velhos desafios. A métrica se manteve coerentemente dentro das sete sílabas. Setessilábicas eram as xácaras mais populares, os romances, as gestas guerreiras. (p. 19)
} 
jagunço para se tornar totalmente paladino, e cerzindo, pelos desígnios da música - e das Musas -, quase fausticamente o seu destino, de si para os outros, de si sobre os outros. Aliás, é importante lembrar que, quando Riobaldo se torna o Urutu Branco, chefe dos jagunços, após o suposto pacto com o diabo, Siruiz passa a ser o nome de seu cavalo de estimação, indômito e belo animal que só ele conseguia cavalgar, que só ele conseguiu domar e tomar-lhe as rédeas, conduzindo-o de próprio braço. Relembremos, agora, e na íntegra, essas primeiras quadras compostas pelo letrado jagunço, apresentadas dentro de seus epifânicos contextos de criação e de aparição no romance.

A primeira das quadras remete Riobaldo a um momento de enorme ócio e insatisfação que, inclusive, dialoga com a viola da solidão da última estrofe da canção de Siruiz: Ah, meu senhor, homens guerreiros também têm suas francas horas, homem sozinho sem par supre seus recursos também (GSV, p. 332).

Pouco antes do momento da composição desse introdutório esboço de canção, sob a chefia de Zé Bebelo Vaz Ramiro, no quase liso das terras altas, lambendo guerra, Riobaldo e os demais jagunços seguiam sem êxito, aos vintes e trintas, o rastro dos Hermógenes. (GSV, p. 329-330)

Nessa noite muito fria, no oco da paciência e após surpreender o companheiro Conceiço se masturbando e, sem pedir explicação ao jagunço, ter ouvido da boca dele tratar-se da natureza da gente, Riobaldo se pega a lastimar os não-acontecidos do passado e a falta que fazia uma viola e um bom cantor: No peso ruim do meu corpo, eu ia aos poucos perdendo o bom tremor daqueles versos do Siruiz? (GSV, p. 332)

Frustrado, sem canção, sem mulher, recordando os amores passados, os de águas rasas, os de águas profundas, os não-acontecidos, os que desabrocharam e os que perigavam definhar em botão, quase se esquecendo - ou temendo se esquecer - e perdendo o bom tremor dos versos de Siruiz e sem poder desejar e, talvez por isso, desejando ainda mais Diadorim, com dura mão feito o Conceiço, o jagunço sofreou os seus ímpetos. Após, de tudo prostrado, veio-lhe uma ânsia nova, um diverso desejo:

Agora eu queria lavar o meu corpo debaixo da cachoeira branca dum riacho, vestir terno novo, sair de tudo o que eu era para entrar num destino melhor (...) antes do romper das horas d'alva. Saí no grande orvalho. Só os pássaros, pássaro de se ouvir sem se ver. Ali se madruga com céu esverdeado. (GSV, p. 333).

Nessa nova madrugada, novo "quebrar de barras", nova promessa de encontro entre sol e lua, sob o grande orvalho de um céu não menos esverdeado que o de outrora, o da primeira audição da canção de Siruiz, e ouvindo sem ver os pássaros, diante de um buritizal, Riobaldo compôs os versos seus, novos, para juntar com os antigos - os de Siruiz -, já quase a se perderem na memória, justificando-se: (...) porque num homem que eu nem conheci-aquele Siruiz - eu estava pensando. (GSV, p. 333): 


\section{Trouxe tanto este dinheiro \\ o quanto, no meu surrão. \\ pr'a comprar o fim do mundo \\ no meio do Chapadão}

\section{Urucúia - rio bravo \\ cantando à minha feição: \\ é o dizer das claras águas \\ que turvam na perdição.}

Vida é sorte perigosa

passada na obrigação:

toda noite é rio-abaixo

todo dia é escuridão...

Assim Riobaldo se refere ao momento exato da criação dessa sua aparente primeira canção:

O que me agradava era recordar aquela cantiga, estúrdia, que reinou para mim no meio da madrugada, ah, sim. Simples digo ao senhor: aquilo molhou minha idéia. Aire, me adoçou tanto, que dei para inventar, de espirito, versos naquela qualidade. Fiz muitos, montão. Eu mesmo por mim não cantava, porque nunca tive entoo de voz, e meus beiços não dão para saber assoviar. Mas reproduzia para as pessoas, e todo o mundo admirava, muito recitados repetidos. Agora, tiro sua atenção para um ponto: e ouvindo o senhor concordará com o que, por mesmo eu não saber, não digo. Pois foi-que eu escrevi os outros versos, que eu achava, dos verdadeiros assuntos, meus e meus, todos sentidos por mim, de minha saudade e tristezas. Então? Mas esses, que na ocasião prezei, estão gôros, remidos, em mim bem morreram, não deram cinza. Não me lembro de nenhum deles, nenhum. O que eu guardo no giro da memória é aquela madrugada dobrada inteira: os cavaleiros no sombrio amontoados, feito bichos e árvores, o refinfim do orvalho, a estrelad'alva, os grilinhos do campo, o pisar dos cavalos e a canção de Siruiz. (GSV, p. 137-138)

Sobre esses versos e canções cerzidos pelo próprio Riobaldo, de que ele diz ter esquecido, mas que os reproduz em sua narração, os estudiosos e especialistas - como já fora mencionado neste estudo - até agora, se calam. Luiz Roncari, concordando com Consuelo Albergaria, apenas afirma se tratar de versos "de quem é mais levado pelas águas turvas do rio da infância do que se conduz seguindo os próprios projetos" (2004, p. 80) ${ }^{184}$, mas isso não nos parece ser o bastante. Para Gabriela Reinaldo (2005: 117), as primeiras tentativas

${ }^{184}$ RONCARI (2004: 85), ao tratar dos versos de Riobaldo, analisando-os em perspectiva comparada com a canção de Siruiz, afirma ainda: [Riobaldo] refere-se aqui a dois tipos de versos: um que prenunciava sua história ainda não acontecida e que vinha do outro para ele: Siruiz canta e ele se encanta; e outro, que também falava de si ou lamentava a sua sorte, "outros versos", "dos verdadeiros assuntos, meus e meus, todos sentidos por mim, de minha saudade e tristezas", e feito por ele para o outro, mas que não se efetivavam: ele não os canta para ninguém, "estão goros, remidos, em mim bem morreram, não deram cinza”. Isso, talvez, pelo fato de sua expressão lírica não ultrapassar o plano subjetivo e intimista, pois falava apenas de si e caía naquilo que Guimarães repelia: "Não se pode tratar o infinito com intimidade, nem com subjetivismo" (Lorenz, p. 89, apud Coutinho, 1983). Ao contrário do primeiro tipo de versos, os da canção de Siruiz, que ele "reproduzia para as pessoas, e todo o mundo admirava, muito recitados repetidos". O modelo dessa canção que o impactara e ele imitava, reproduzia e agradava a todos, estava ligado a uma situação que o envolvera integralmente como homem. O que dava objetividade à canção [de Siruiz] era o fato de ela falar não apenas de um sujeito, mas do destino de uma camada de homens, da qual o herói provinha e com a qual se identificava.

Concordamos com a importância que Roncari dá à canção de Siruiz, mas não achamos que os versos compostos por Riobaldo são tão desimportantes assim, pelo contrário, acreditamos que esses versos e quadras são mais uma chave de compreensão das metamorfoses vividas por Riobaldo, quando o jagunço que se crê pactário toma ou tenta tomar as rédeas de seu destino, e desenvolveremos essa tese na sequência dos estudos. 
de versificação de Riobaldo não passam de um esboço de "uma cantiga que fala do erro, do engano, das coisas passageiras, da guerra, das necessidades, dos perigos. Versos que não aliviam Riobaldo, nem lhe dão refrigério", mas isso também, ao nosso ver, está longe de ser o suficiente para esclarecer os desígnios da canção e a importância dela para o Grande sertão: veredas.

É Candido, mais uma vez, em seu "O homem dos avessos”, quem nos parece fornecer uma possível chave para um mergulho mais profundo na compreensão desses escritos tão singulares e tão sinuosos, versos talvez tão enigmáticos quanto a própria canção de Siruiz. Para ele, as caudalosas "águas turvas" da personalidade de Riobaldo, presentes nessas quadras, linhas e versos representam o suposto pacto com o demônio e suas consequências. Tomemos o trecho do ensaio em que o crítico evidencia essa relação (os grifos são nossos):

(...) vemos misturarem-se [em Grande sertão: veredas] em todos os níveis o real e o irreal, o aparente e o oculto, o dado e o suposto. A soberania do romancista, colocado na sua posiçãochave, a partir da qual são possíveis todos os desenvolvimentos virtuais, nos faz passar livremente duma esfera à outra. A coerência do livro vem da reunião de ambas, fundindo o homem e a terra e manifestando o caráter uno, total, do Sertão-enquanto-Mundo.

(...) Aqui, além do que ficou indicado, o tônus é devido à crispação incessante do narrador em face dos torneios de expressão, elaborados e reelaborados a cada página em torno das obsessões fundamentais. Deve-se ainda ao símbolo escolhido para dinamizar a recorrência (o pacto com o demônio), e que representa as caudalosas águas turvas da personalidade. Esse é o princípio, a ideia que enforma Grande Sertão: Veredas, e em relação a ele o demônio adquire significado algo diferente do que vimos. Quando se tratava da inserção de Riobaldo na sua tarefa (ou missão), importou ressaltar o aspecto de instrumento iniciatório; mas se encaramos a individualidade de Riobaldo, a sua condição singular de homem, o demônio volta a simbolizar, como para Fausto ou Peter Schlemilh, a tentação e o mal." (1991:305)

No momento da composição dos versos que davam sequência à canção de Siruiz - versos esses que vieram como uma ânsia, um desejo enorme, uma pulsão irrefreável e irreprimível -, no clamor do próprio narrador-cantor Riobaldo, de sair de tudo o que era, para entrar num destino melhor, o herói estava mesmo começando, por premonitória ou intuitiva antecipação aos fatos, a tomar as rédeas de seu destino de chefe Urutu Branco e a tornar Siruiz seu cavalo de estimação: animal de sua posse, com quem, a seu mando, cavalgaria a iniciática e árida, dada e suposta, divina e diabólica, fabular e seca travessia do Liso do Sussuarão para vencer o Hermógenes e a si mesmo e se encontrar, novamente, com a sua singular condição de homem, seu Graal sertanejo, sua estória e história.

E esse novo destino, mesmo sinalizado anteriormente ao suposto pacto apontado por Candido como um potente "símbolo escolhido para dinamizar a recorrência" da narrativa, já se prenunciava na canção. Prenunciava-se nas águas do Urucúia - rio bravo - cantando à sua feição e tornando as outrora contemplativas, remansadas, claras e largas águas do rio baldo em turvas águas da perdição. 
Mesmo supostamente não cantando esses versos para ninguém e achando que eles eram gốros, que não tinham valor, nem lhe davam refrigério - afirmando que $A$ virtude que tivessem de ter, deu de se recolher de novo em mim a modo que o truso dum gado saído, que em sustos se revolta para o curral, e na estreitez da porteira embola e rela. (GSV, p. 334) -, mesmo - e talvez mais por isso - pouco antes do momento de sua criação, tendo que encarar de frente a morte - levando uma bala de raspão -, Riobaldo começava já a não aceitar, calado e contemplativo feito o boi mocho, baetão introduzido pela canção de Siruiz, os mandos e desmandos de seu chefe Zé Bebelo ou os de seu próprio neblinado destino de outrora. Tatarana - variante de taturana - começava, ainda que no casulo, contudo já como crisálida ${ }^{185}$, a vislumbrar as metamorfoses que sofreria e que seu novo destino e as "caudalosas águas turvas de sua personalidade" lhe reservavam.

Nesse momento da estória, quando sob o cerco dos hermógenes, um Riobaldo emergindo da pupa questionaria a ordem de Zé Bebelo de mandar missivas às autoridades governamentais dando a localização exata de onde, em guerra, se situavam e, não bastando questioná-lo - coisa que outrora, como mera tata'rana, jamais faria - e, com o sangue lhe esquentando a face, imago a testar as asas, tomaria uma importante decisão:

Desconheci antes e depois - uma decisão firme me transtornava. E eu vi, fiquei sabendo: me queimassem em fogo, eu dava umas labaredas muito altas! Ah, dava. $O$ senhor acha que menos acho? Mais digo. Mais fiz. Antes veja, o que eu pensei -o que seguinte ia ser, e ficou formado um decreto de pedra pensada: que, na hora de os soldados sobrechegarem, eu parava perto do Zé Bebelo; e que, ele fizesse feição de trair, eu abocava nele o rifle, efetuava. Matava, só uma vez. E, daí... Daí eu tomava o comandamento, o competentemente - eu mesmo! - e represava a chefia, e forçando os companheiros para a impossível salvação. (GSV, p. 350)

Riobaldo estava deixando para trás o baldo homem de contemplação e de imobilidade e, feito uma urticante taturana a defender seu futuro de metamorfoses ou feito o Fausto, de Goethe, prometia, se o queimassem em fogo, dar umas labaredas altas. Aliás, também como o Fausto - ou como uma borboleta recém-saída do casulo, inexperiente das asas, todavia sedenta de voo -, ansiava já pela vastidão do mundo e do sertão, pelo pleno conhecimento de tudo, o saber uno do "sertão-enquanto-Mundo", tornando-se um homem de ação.

Quem vence, é custoso não ficar com a cara de demônio (GSV, p. 372), afirma o jagunço aposentado ao seu interlocutor forasteiro, rememorando o momento da chegada da soldadeza pegando de supetão os hermógenes, pela retaguarda ao cerco sofrido sob o comando de Zé Bebelo, e reiterando, logo após, que pouco tempo depois da composição de seus primeiros versos, já podia sentir sua quase obsessiva fixação pelo

\footnotetext{
${ }^{185}$ Crisálida, do latim: chrysaliis, do grego $\chi \rho v \sigma \alpha \lambda \lambda i ́ \varsigma$ = chrysallís, é o estágio de pupa de insetos da ordem lepidóptera. As borboletas adultas emergem das crisálidas, que, no casulo, pouco se movem ou não o fazem. O termo é derivado da coloração metálico-dourada encontrada nas

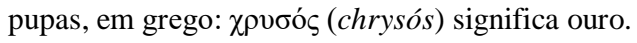


"pacto", decisão que, em breve, tomaria forma e feição, representação das "caudalosas águas turvas da personalidade", como afirmou Candido. E essa decisão chegou certeira, sem titubeios, direta e cronologicamente breve: Aquilo - era eu ir à meia-noite, na encruzilhada, esperar o maligno, fechar o pacto. Fazer o trato. $(G S V$, p. 426)

Assim analisa Candido, ainda em “O homem dos avessos”, a decisão de Riobaldo pelo "pacto":

"Para vencer o Hermógenes, que encarna o aspecto tenebroso da Cavalaria sertaneja um cavaleiro felão, traidor do preito e da devoção tributadas ao suserano - é necessário ao paladino penetrar e dominar o reino das forças turvas. O diabo surge então, na consciência de Riobaldo, como dispensador de poderes que se devem obter; e como encarnação das forças terríveis que cultiva e represa na alma, a fim de couraçá-la na dureza que permitirá realizar a tarefa em que malograram os outros chefes". (1991: 303)

Na nunca esquecida encruzilhada enluarada das Veredas-Mortas, Riobaldo, narrando o momento do suposto pacto com um Diabo de tantos nomes ${ }^{186}$ - em face de uma representação e de uma presentificação do Mal que o leitor da obra jamais saberá se existiu de fato ou não, ou se foi e é apenas parte simbolicamente trazida ao consciente da luta do personagem e da humanidade com o que Freud trataria como suas "pulsões inconscientes", seus demônios interiores ${ }^{187}$-, na hora exata do "trato", à meia-noite, parece ter se deparado com mais uma fonte de dilacerante angústia, de vazio, de falta, em sua vida: não sabia o que "tratar" com Lúcifer, não sabia o que pedir ao Senhor das Trevas - ou do seu inconsciente. O herói se cala.

Após uma instantânea eternidade de um estremecido silêncio, o suposto paladino pactário, buscando dominar o reino das forças turvas aludido por Candido, consegue malemal balbuciar, colocando em palavras rememoradas, seu desejo: E o que era que eu queria? Ah, acho que eu não queria mesmo nada, de tanto que eu queria tudo. Uma coisa, a coisa, esta coisa: eu somente queria era - ficar sendo! (GSV, p. 436)

Com o amanhecer, no retorno ao acampamento para junto dos demais jagunços - e de Diadorim, de si mesmo e de sua estória -, Riobaldo, após afirmar que o dia foi orvalhando, ainda se indaga, mais uma vez sem esperança de resposta: Posso me esconder de mim?... (GSV, p. 439)

Cumprido o rito, afirma Candido, "o narrador aparece marcado pelo sinal básico da teoria iniciatória: a mudança do ser". Sem poder se esconder de si, passa a ficar sendo - não a ficar, nem a ser, mas a "ficar sendo", numa locução verbal que atrela um verbo auxiliar no infinitivo e um verbo principal no gerúndio

\footnotetext{
${ }^{186}$ Dentre tantos, escolhemos apenas alguns dos nomes do diabo da coleção rosiana, os que consideramos mais significativos à atual reflexão, como ilustração: o Sempre-Sério, o Pai da Mentira, o Pai do Mal, o Austero, o Severo-Mór, o Ele, o Solto-Eu

${ }^{187}$ Aliás, dúvida essa que é o mote essencial da obra e que permeia toda a narrativa, fazendo o seu protagonista constantemente buscar, sem resposta, a Deus, e encontrar-se com o demo, mesmo que apenas na sua forma anagramática de medo.
} 
indicando uma contínua ação jamais finalizada, um tempo em suspensão, um aparente "rito de passagem", um eternizado processo de constante metamorfose e mutação. E Candido prossegue:

"O iniciado, pela virtude das provas a que se submeteu, renasce praticamente (...) Em Grande Sertão: Veredas, Riobaldo sai transformado - endurecido, arbitrário, roçando a crueldade, na prepotência das funções de mando que logo assume, em contraste com a situação anterior, em que as tinha rejeitado. Mesmo o seu sentimento por Diadorim, que apesar da revelação em Guararavacã do Guaicuí tinha permanecido nos limites da dúvida, ou pelo menos da severa repressão, desponta com certa agressividade, como se os impulsos estranhos (dada a ignorância do verdadeiro sexo do amigo) tendessem agora a manifestar-se, com a sanção do pacto. (...)

Essa transformação, esse ingresso numa certa ordem de ferocidade adequada à vitória, que pretende e obtém sobre o mal (Hermógenes), através do mal (o pacto), é completada por outros sinais de caráter mágico, como a adoção do nome de guerra que Zé Bebelo lhe pusera vagamente, e quase por pilhéria, mas que agora é assumido em seu significado pleno: Urutu Branco.” (1991: 304)

Riobaldo, agora, passa, a pouco e pouco, a ficar sendo um homem forte, decidido, vitorioso, disposto a enfrentar qualquer travessia, inclusive a do Liso do Sussuarão, outrora jamais vencida por outro jagunço, disposto a enfrentar o Hermógenes e, mais importante do que tudo, disposto a enfrentar a si mesmo e a seus medos - anagramaticamente seus demos - interiores, e a, fausticamente, dominar a "encarnação das forças terríveis que cultiva e represa na alma, a fim de couraçá-la na dureza que permitirá realizar a tarefa em que malograram os outros chefes" denotada por Candido, e isso ficará marcado e, mais e mais, evidenciado em seus versos e canções.

Marcus Mazzari, em seu "Veredas-Mortas e Veredas-Altas: a trajetória de Riobaldo entre pacto demoníaco e aprendizagem", também trata da transformação vivida pelo herói - aliás, fazendo uso das próprias metáforas do narrador, de rato num tigre leão -, após o episódio das Veredas-Mortas, e da relação disso com os versos por ele compostos:

À luz dessa portentosa transformação seria sobremaneira elucidativo comparar os versos que Riobaldo compõe antes e depois do pacto. Desse modo se poderia demonstrar a primazia de imagens de turvamento, opacidade e fragilidade nas três quadras que ele acrescenta "descontente de que sejam sem razoável valor" - à canção de Siruiz. Já nas três outras quadras concebidas pelo chefe Urutu Branco, predominam (às expensas da dimensão lírica) sugestões de poder e força: a referência explícita ao "trato com o Cão", a capacidade de permutar entre o "sim" e o "não", o estouro do gado bravio, a autodenominação de "Rei do Sertão" e "Capitão" (termo esse que pode ser lido como anagrama de "pacto"). (2010: 6970) 
O Tatarana, lagarta de fogo, com o suposto - acreditado - pacto, se metamorfoseia em chefe Urutu Branco $^{188}$, torna-se decidido, de bote certeiro e agressivo como uma cobra urutu; todavia, como na tradição dos Faustos, "endurecido, arbitrário, roçando a crueldade", a ele, tomado pela frieza ${ }^{189}$ dos pactários e supostos pactários, não é dado o direito à felicidade amorosa. Converte-se num homem frio, autoritário, prepotente. E é Diadorim, aliás, a mesma que lhe incentivou a se tornar chefe, aquela a quem deverá de renunciar, quem primeiro nota a mudança, chegando a lhe perguntar: alguém te botou malefício?

Antes de tratarmos de forma mais aprofundada do suposto trato de Riobaldo com o diabo, de suas intercorrências e consequências, debrucemo-nos, ainda, um pouco mais sobre a primeira canção composta pelo lírico jagunço - canção essa na qual, como afirmamos, já se vislumbrava esse hipotético pacto e que, de certa maneira, já o propunha -, quando ainda Tatarana, lagarta de fogo, e na decifração mais minuciosa e pontual de seus versos. E iniciaremos nossa análise pela primeira quadra:

\section{Trouxe tanto este dinheiro o quanto, no meu surrão. pr'a comprar o fim do mundo no meio do Chapadão}

Por conta da temática da jagunçagem, a referência ao dinheiro é recorrente em Grande sertão: veredas. Além da citação no primeiro verso da primeira quadra da canção feita por Riobaldo, que trataremos de analisar, o termo "dinheiro" aparece quarenta e cinco vezes no romance, porém, apenas numa vez a citação não é em seu caráter literal e utilitário, de compra, de venda, de demanda, encomenda, recompensa, extorsão ou quitação: no trecho em que Riobaldo afirma que ele não gosta de se esquecer de coisa nenhuma: Esquecer, para mim, é quase igual a perder dinheiro. (GSV, p. 423)

\footnotetext{
188 Já tratamos, em nota, de vários significados simbólicos possíveis para o nome Urutu Branco, no Grande sertão rosiano. MAZZARI (2010: 73), também em nota, aponta outro, de significativa importância, que diz respeito ao motivo do pacto e à associação simbólica da serpente com o diabo: "O Antigo e o Novo Testamento oferecem não poucas passagens que ilustram essa associação da serpente com o diabo. No Apocalipse (12:9) lê-se, por exemplo: 'Foi expulso o grande Dragão, a antiga serpente, o chamado Diabo ou Satanás, sedutor de toda a terra habitada"'.

${ }^{189}$ MAZZARI (2010: 67-68) trata do frio tão comum às descrições de cenas dos pactos com o diabo nas obras que abordam o motivo fáustico o Fausto anônimo de 1587; A trágica história do doutor Fausto, de Marlowe; o Fausto, de Goethe; os Irmãos Karamázov, de Dostoiévski; o Doutor Fausto, de Tomas Mann - além de relembrar a glacial Judeca do nono e último círculo do Inferno de Dante - onde penam os que traíram a frio, como Judas, Brutus e Cássio, dentre tantos outros -, para analisar o frio inteiriço que envolve Riobaldo após o episódio das gélidas Veredas-Mortas - com a descrição da água fria no bebedouro dos veados e onças - e a autotraição e renúncia ao amor dos "pactários". Enfatizando a condição que o diabo estipula ao músico Leverkühn, no romance de Mann, em troca de seus préstimos - "A tua vida terá de ser fria. Por isso não poderás amar" - Mazzari pontua: "Com esse mandamento de renúncia ao amor (ao qual se atribui a faculdade de "aquecer") não estaria se explicitando componente incontornável nas histórias de pacto demoníaco, de tal modo que a transgressão tem por consequência a perda do ser amado - no Doutor Fausto a morte inominável do pequeno Nepomucek, no Grande sertão a perda trágica de Diadorim”. Em nota, ainda, o crítico trata também da renúncia amorosa no Fausto de Goethe e em outros clássicos da literatura fáustica:

A ilustração mais expressiva para esse componente sub-reptício de histórias de pactuários se encontra na última cena do Fausto I ("Cárcere"), em que Gretchen aguarda enlouquecida a execução. Não por acaso, também Adelbert von Chamisso (1781-1838), em sua História Maravilhosa de Peter Schlemilh (1814), obra-prima do romantismo alemão, faz o herói - e apenas "semipactuário" - passar pela perda da mulher amada. A proibição categórica de um amor que possa levar ao sacramento do matrimônio está presente no livro de 1587, mas se explicita mais claramente numa de suas adaptações, publicada em 1775 por um anônimo cristão "bem-intencionado" (Das Faustbuch des Christlich Meynenden): trata-se do episódio em que o pactuário se apaixona por uma criada bela mas pobre; uma vez, contudo, que a moça não lhe permite nada fora do casamento e ele se dispõe assim a dispensá-la, eclode áspero conflito com o seu parceiro demoníaco.
} 
Tal afirmação do guerreiro-aposentado ancorado no passado em busca de sentidos, relevante para a interpretação dos versos da canção, refere-se à narração de um momento de inesperado caiporismo de Zé Bebelo, num lugar denominado Coruja ${ }^{190}$, em face de um surto de malária e de outros males que acometeram muitos jagunços do bando por ele chefiado, e no qual Riobaldo ainda se incluía:

Sempre Zé Bebelo não desistia de palavrear, a raleza de projetos, como faz-de-conta. A mó de moinho, que, nela não caindo o que moer, mói assim mesmo, si mesma, mói, mói. As doenças se curassem? Minhas dúvidas. Aí, quem não pegara a maleita padecia por outros modos - mal-de-inchar, carregação-do-peito, meias-dores; teve até agravado de estupor. Adiantemente, me desvali. $O$ que me coçava, que nem se eu tivesse provado lombo de capivara no cio. A ser, o fígado, que me doía; mas não me certifiquei: apalpar lugar de meu corpo, por doença, me dava um desalento pior. (GSV, p. 421-422)

Descrevendo em detalhes esse momento crítico do bando e rememorando o desejo dos jagunços de, de hora para outra e sem justa motivação, invadir algum vilarejo próximo, em tiroteio, só para exercício de não se minguar (...) e se pandegar, depois, vadiando... (GSV, p. 422), Riobaldo, avalia os modos jagunços, suas ambivalências, seus valores e horrores, e a responsabilidade dele nisso tudo, além de seu poder sobre o próprio destino e o dos outros:

(...) eu ficava imaginando: se fosse eu tivesse tido sina outra, sendo só um coitado morador, em povoado qualquer, sujeito à instância dessa jagunçada? A ver, então, aqueles que agorinha eram meus companheiros, podiam chegar lá, façanhosos, avançar em mim, cometer ruindades. Então? Mas, se isso sendo assim possível, como era pois que agora eles podiam estar meus amigos?! O senhor releve o tanto dizer, mas assim foi que eu pensei, $e$ pensei ligeiro. Ah, eu só queria era ter nascido em cidades, feito o senhor, para poder ser instruído e inteligente! E tudo conto, como está dito. Não gosto de me esquecer de coisa nenhuma. Esquecer, para mim, é quase igual a perder dinheiro. (GSV, p. 423)

Nota-se, com a análise e transcrição desses trechos do Grande sertão, o valor que o narrador dá à memória. Feito os antigos aedos gregos inspirados pelas Musas e em constante combate contra Lete, o letal esquecimento, ou feito um adepto da psicanálise freudiana moderna, Riobaldo se utiliza quase que o tempo todo da rememoração para tentar reorganizar seus passos, para tentar revisar, de forma crítica, sua travessia, seus fatos, seus atos, visando entendê-los e reelaborá-los para, quem sabe, poder entender-se melhor também, neles e com eles. E para poder se sentir menos desvalido.

Riobaldo é um ser amparado pela cultura oral, mesmo sem entender tocado pelas Musas e, por isso, aprendeu delas e com elas o valor da memória, a importância do não se esquecer, a busca da fonte pulsante,

\footnotetext{
${ }^{190}$ A coruja, popularmente conhecida como pássaro da morte e do mau agouro, é a ave da deusa grega Atena - Minerva entre os romanos - e, segundo CHEVALIER e GHEERBRANT (2000: 293), simboliza a reflexão que domina as trevas. Segundo o Dicionário de Símbolos, na mitologia grega, a coruja, representada por Ascálafo, filho de Aqueronte e da ninfa da obscuridade, foi quem viu Perséfone (Prosérpina) provando um "fruto do inferno" (um bago de romã) e denunciou-a, privando-a assim de toda e qualquer esperança de um dia poder retornar definitivamente ao mundo da luz.
} 
primordial, patrimonial, da vida. Importância maior até do que a do dinheiro. Todavia, parece que o mero “não se esquecer” não é o bastante para esse insatisfeito jagunço que se diz ignorante. Riobaldo, feito o protagonista do mito fáustico, tal e qual os diversos Faustos - o histórico de 1587, o de Marlowe ou o de Goethe, o de Mann, dentre outros -, quer mais; sedento de conhecimento, ele busca o absoluto, busca a plena compreensão, a total sabedoria, almeja tocar o eterno e compreender o misterioso e o obscuro. Na voz do próprio narrador sertanejo, quer ser instruído e inteligente!

Sabemos que, no momento da composição dos seus primeiros versos, Riobaldo estava começando a temer se esquecer da canção de Siruiz, e, aliás, muito antes dessa sua copla nascer, o próprio Siruiz já parecia estar morto, parecia quase ter sido engolido por Lete. Vimos, inclusive, que no mesmo instante em que Riobaldo aprendeu a canção "Olererê Baiana”, ele tomou consciência, pela voz do jagunço Garanço, da provável morte do violeiro:

(...) me lembrei em madrugada daquele nome: de Siruiz. Refiro que perguntei ao Garanço, por aquele rapaz Siruiz, que cantava cousas que a sombra delas em meu coração decerto já estava. O que eu queria saber não era próprio do Siruiz, mas da moça virgem, moça branca, perguntada, e dos pés-de-verso como eu nunca tive poder de formar um igual. Mas o Garanço já tinha respondido. - "Eh, eh, ô... O Siruiz já morreu. Morreu morto no tiroteio, entre o Morcego e o Suaçuapara, passado para cá o Pacuí...” Do choque com que ouvi essa confirmação de notícia, fui arriando para um desânimo. Como se assim ele tivesse falado: "Siruiz? Mas não foram vocês mesmos que mataram?...” Eu, não. Nessa vez, eu tinha restado longe por fora, na Pedra Branca, não vi combate. Como era que eu podia? $O$ Garanço tomava rapé. Era um sujeito de intenções muito parvas. Perguntou se o Siruiz não seria meu amigo, meu parente. - "Quem sabe se era...”- eu respondi, de toleima. $O$ Garanço, vi que não gostou. Viver perto das pessoas é sempre dificultoso, na face dos olhos. Nem eu quis indagar o mais, certo estava de que ele Garanço não sabia nada do que tivesse valor. Mas eu guardava triste de cor a canção recantada. E Siruiz tinha morrido. Então me instruíram na outra, que era cantiga de se viajar e cantar, guerrear e cantar, nosso bando, toda a vida:

“Olererêêê, baiana...

Eu ia e

não vou mais:

Eu faço que vou lá dentro, oh baiana, e volto do meio

p’ra trás...” (GSV, p. 192-193)

Riobaldo ao perguntar sobre o destino do violeiro, neste trecho da narrativa, sintetiza as principais demandas de sua própria travessia: queria saber do rapaz Siruiz que cantava cousas que a sombra delas em seu coração decerto já estava, queria saber da moça virgem, moça branca perguntada, e queria saber dos pés-de-verso, como nunca teve poder de formar um igual. E o companheiro Garanço não apenas lhe comunica a morte do violeiro, como também pergunta se não fora ele mesmo o responsável por essa morte. No que o jagunço nega com veemência: Garanço não sabia nada do que tivesse valor. 
Sabemos, contudo, que, pelos meandros sinuosos da linguagem rosiana, como bem diria Freud, se alguém não sabe nada, em denegação, é bem provável que, no mínimo, mesmo conscientemente sem saber, possa saber muito. E Riobaldo sabia, com certeza, ao menos que Siruiz tinha morrido. E, com sua morte, talvez também o mistério da moça virgem.

Voltando ao que, de fato, era de maior valia para Riobaldo, muito mais valioso do que o dinheiro, voltamos também à finalização da interpretação da primeira copla de sua canção. Era de lembranças, de rememoração, que se abastecia o seu surrão ${ }^{191}$, daquilo que ele guardava triste de cor, como a canção recantada e que, feito o surrão medieval, lhe servia de guarita e proteção. De reminiscências compunha-se seu bornal de provisões, de memórias e de desejo de reorganizar, de ressignificar, por meio delas, sua travessia, valorosa vontade de trazer significado novo a sua vida, de manter vivo mesmo o que a morte levara ou prometia levar. O quanto de dinheiro que o jagunço levava em sua cruzada pelo sertão era o quanto do que não queria e do que não podia se esquecer e se desfazer, o quanto do que se tornaria sua estória.

E, tal e qual Fausto, esse Riobaldo insatisfeito e buscador não mediria esforços na tentativa de alcançar o absoluto, de encontrar a plena sabedoria, não abriria mão do desejo de compreensão de todos os mistérios, da ansiada vitória sobre Letes. Para tanto, compraria - com dinheiro, com memória, com estória, com canção -, se preciso fosse, inclusive, o fim do mundo no meio do Chapadão e, nessa plena negociação com o demo e com seus medos, consigo e com as fontes do seu ser, também como aconteceu com Fausto, acabaria por se despojar do medo maior, não temeria sequer vender algo de valor crucial e atemporal: a própria alma. Afinal, sabia Riobaldo o preço a se pagar pela inestimável ambição da conquista do fim do mundo, do desvendar de todos os mistérios, inclusive o daquela moça virgem evocada numa orvalhada madrugada de maio e desejada por toda a vida.

A segunda estrofe da canção concebida por Riobaldo, como já tratamos neste estudo ${ }^{192}$ e, portanto, retomaremos de forma mais sucinta, diz respeito aos primeiros anseios e vislumbres do suposto pacto do narrador-jagunço com o diabo, além dos trâmites e trânsitos necessários à sinistra negociação.

\footnotetext{
${ }^{191}$ COIMBRA, Álvaro da Veiga, aponta que o termo surrão, típico dos sertões brasileiros, origina-se da palavra francesa sarrau, e foi por longo tempo a alcunha utilizada para que se fizesse referência às sobrecotas nas indumentárias medievais. Tal termo apresenta ainda corruptelas como çurame. O surrão, saco ou bornal de couro, era, na Idade Média, um item de armadura medieval responsável pela proteção do corpo; era constituído de uma larga chapa forjada em ferro, que devia ser sobreposta no peito por cima de outra armadura, no caso a lóriga de malha. (Noções de Numismática. SP. Secção Gráfica da Faculdade de Filosofia, Ciências e Letras da Universidade de São Paulo, 1965).

192 Vide págs. 54, 79 e 80.
} 


\section{Urucúia - rio bravo \\ cantando à minha feição: \\ é o dizer das claras águas \\ que turvam na perdição.}

Já tratamos da identificação de Riobaldo com o rio Urucuia e do quanto esse rio remansado e de claras águas próximas à nascente pode, de hora para outra, tal e qual os próprios caminhos de Riobaldo em meio ao grande sertão rosiano, se tornar um rio de agitadas - avermelhadas - águas que turvam na perdição. Tratamos do quanto, à medida que Riobaldo vai se esquecendo - ou pensando se esquecer - da canção de Siruiz e do próprio violeiro morto, vai, também, tomando as rédeas de seu destino e deixando de ser boi mocho para, a pouco e pouco, ir se tornando um desgarrado boi barbatã ${ }^{193}$. Agora chegou a hora de contextualizarmos essas mudanças já previstas e preditas nos primeiros versos da canção do épico-lírico jagunço.

Se, em Grande Sertão: Veredas, certas músicas como "Olererê Baiana" estão associadas - como aponta Reinaldo (2005: 111) - ao esquecimento momentâneo das dificuldades vividas pelos jagunços, funcionando como fontes de restauração das forças e revigoração para o combate, vimos também que, como afirmam as Musas da Teogonia de Hesíodo, só pelo canto podemos vencer o esquecimento. E isso fica bastante claro ao atentarmos para os ditos ainda inexperientes versos gôros, remidos, dessa segunda quadra de canção.

Notamos, nessa quadra, que o jagunço-cantor já intuía ou vislumbrava que apenas o reflexo do bravo e potente Urucuia, símbolo de cristalina e pura nascente, de rubra metamorfose guerreira e de turva travessia pelo sertão, poderia cantar à sua feição - à feição de um fáustico Riobaldo sedento de imensidão e de compreensão dos turvos mistérios do sertão, de um jagunço peregrino que, feito o protagonista do mito fáustico, deseja um poder que não se resume em acúmulo de riqueza ou de dinheiro e que não se limita a uma vida de remansos.

Riobaldo refletia em seus versos a ânsia por uma capacidade de comandar e de liderar - aos outros, a si - que o ajudasse a deixar no passado o que lhe desvalia e, ao mesmo tempo, que o impedisse de deixar para trás o que the era de maior valor, evitando, assim, que o paladino se esquecesse do que acreditava ser sua sede maior: a sede do absoluto. E, como um bom Tatarana, sabia que, para a gente se transformar em ruim ou em valentão, ah basta se olhar um minutinho no espelho - caprichando de fazer cara de valentia; ou cara de ruindade! (GSV, p.62). O lírico guerreiro intuía que o Urucuia era seu espelho.

Se o espinho com o espinho, pelas dialéticas elaborações filosóficas - ou alquímicas - de Riobaldo, terminam por as espinheiras se quebrar e se Deus espera essa gastança (GSV: p.33), o melhor, para vencer

${ }^{193}$ Rês bravia, "braba", desgarrada e criada no mato. 
o mal, seria fazer um trato com o próprio Mal, tingir-se de vermelho como o Urucuia, "gastar" o que Deus o de Jó, o de Fausto - espera que se gaste, evocando, para isso, nos caminhos da perdição, em meio às Veredas-Mortas, por três vezes, as forças do Malévolo, e clamando pelo Cujo.

Ainda que Riobaldo não tivesse a total certeza disso, a decisão pelo Pacto já estava tomada: Queria entender do medo e da coragem, e da gã que empurra a gente para fazer tantos atos, dar corpo ao suceder. O que induz a gente para más ações estranhas, é que a gente está pertinho do que é nosso, por direito, e não sabe, não sabe, não sabe! (GSV, p.116).

Firmada a decisão pelo Pacto - mesmo que ainda aparentemente inconsciente - e, em face da possibilidade da venda de sua alma ao diabo em troca da vitória sobre o Hermógenes, sobre si mesmo e sobre suas recalcadas erranças, Riobaldo começa a se ater com as "contabilidades” da vida, aliás, já abordadas na primeira quadra da canção. E, ancorados nisso, debruçamo-nos sobre a análise da terceira quadra e sobre os vislumbres de interpretações que ela suscita:

Vida é sorte perigosa
passada na obrigação:
toda noite é rio-abaixo
todo dia é escuridão...

Viver é um descuido prosseguido (GSV: p. 86), afirma Riobaldo, ao refletir sobre sua vida e sua sina, e, noutro trecho do romance, o narrador que crê e não se crê pactário comenta ao seu interlocutor calado: Digo ao senhor: tudo é pacto. Todo caminho da gente é resvaloso. Mas; também, cair não prejudica demais - a gente levanta, a gente sobe, a gente volta! (GSV: p. 328-329).

Nessa vida de sorte perigosa, passada toda na obrigação, Riobaldo contabiliza que toda noite é rioabaixo e conclui que, seguindo o curso do caudaloso e bravio rio, que é a representação especular de sua própria existência sertaneja, se cai um pouco a cada noite, e que, no outro dia, buscando luz e muitas vezes se ofuscando com ela, o que geralmente se encontra é - paradoxalmente e, novamente em acordo com o “princípio da reversibilidade" - escuridão, aliás, todo dia é escuridão... Sendo assim, só um pacto mesmo, só um trato com o diabo - "dispensador de poderes que se devem obter para ajudar a se levantar", como afirma Candido - para se poder subir, levantar, para se almejar voltar. E o jagunço aposentado tem uma certeza e uma paciência típicas de Jó: [...] cair não prejudica demais - a gente levanta, a gente sobe, a gente volta! 
Riobaldo, supostamente apenas querendo um divertimento de alívio, compõe uma canção que parece desejar completar ou dar prosseguimento, a sua maneira, à de Siruiz, além de tentar responder às suas perguntas, inclusive sobre a moça virgem. Ao compor essas quadras de próprio punho, versos neblinados e iluminados pela canção de outrora, o jagunço busca reacender e reascender lembranças de um passado talvez sequer acontecido, mas nem por isso menos desejado, esperado, tornado em estória, um passado sem retorno, sem presente ou futuro, todavia almejado, demandado, um revés no tempo e nos acontecidos e nãoacontecidos do tempo. E, desafiando um Cronos que abocanha os próprios filhos, deles se alimentando, além de alumiar lembranças, quebrando barras, o herói tenta antever o futuro e, com ele, pactuar. 


\section{NO MEIO DO REDEMOINHO}

- “Você sabe do seu destino, Riobaldo?”- ele reperguntou. Aí estava ajoelhado na beira de mim.

- “Se nanja, sei não. O demônio sabe..." - eu respondi.

(Grande sertão: veredas, Guimarães Rosa) ${ }^{194}$

É logo após o suposto pacto com um diabo de muitos nomes - todavia, como afirma Albergaria, sem presença concreta ou aparência visível e comprovada - que Riobaldo compõe os seus seguintes versos, a segunda parte do que afirmara ser o desejo da continuação da canção de Siruiz. Agora, contudo, essa nova composição, já tratada assumidamente como canção sua, é exibida e compartilhada com todos.

Assim narra o aedo jagunço a gênese da canção:

(...) eu tinha conseguido encher em mim causas enormes. Dispor do ror daquilo eu não conciliava, conforme perseguia, custoso, vermelho meu. Somente quis, nem podia dizer aos outros o que queria, somente então uns versos dei, que se puxaram, os meus, seguintes:

Hei-de às armas, fechei trato

nas veredas com o Cão.

Hei-de amor em seus destinos

conforme o sim pelo não.

Em tempo de vaquejada

todo boi é barbatão:

deu doideira na boiada

soltaram o Rei do Sertão...

Travessia dos Gerais

tudo com armas na mão...

O Sertão é a sombra minha

e o rei dele é o Capitão!...

(GSV, p. 479)

Por mais que o eu lírico de sua canção afirme ter "fechado trato com o Cão", Riobaldo - assim como nós, seus ouvintes-leitores - jamais saberá - ou saberemos -, com certeza, se fez ou não esse "trato".

Mazzari (2010), analisando se houve ou não a consumação do pacto demoníaco, no Grande sertão rosiano, reflete sobre a falta de presença objetiva do diabo na trama e, consequentemente, trata da consumação ou não da aliança com ele, trazendo nova luz à discussão:

Se, desde o início, Riobaldo não esperava deparar-se com uma aparição aterradora, à semelhança da que se manifesta no Fausto de Marlowe, ou envolta em fumaça e cheiro de

${ }^{194}$ Grande Sertão: Veredas. 19ª ed. Rio de Janeiro: Nova Fronteira, 2001, p. 212. 
enxofre, ou ainda em meio a vendaval tremendo (como no livro anônimo de 1587), ao fim do ritual vem-lhe a intuição de que talvez tenha ido ao encontro de um "falso imaginado". Por outro lado, contudo, fica-lhe também a sensação de ter sido ouvido no "envir dos espaços" em meio ao silêncio noturno: "Mas eu supri que ele tinha me ouvido". Aparentemente numa dimensão subjetiva, delineia-se então um "catapruz de sinal" e a Riobaldo parece confirmar-se a condição de pactário ao sentir um "adejo", um "gozo de agarro", desencadeando imagens de um novo nascimento ("rio que viesse adentro a casa de meu pai”) e, por conseguinte, de um novo poder. (2010: 64)

O "trato com o Cão", independentemente de ter sido feito ou não, portanto, ao nosso ver - e em concordância com Mazzari -, surge como um "novo nascimento" para Riobaldo, empoderando-o na forma de uma libertação psíquica, arma contra o recalque e a repressão, como fluxo irrefreado e irrefreável de vontade, jorro de instintos e pulsões, rio em tororoma ${ }^{195}$ que, edipicamente, adentra a casa do próprio pai. E Mazzari prossegue a discussão:

(...) toda a maestria artística envolvida na representação dos passos de Riobaldo nas VeredasMortas consiste em deixar os eventos oscilarem incessantemente entre as esferas da subjetividade e da objetividade. Ao ouvinte e leitor subtrai-se, com o jogo cambiante de afirmativas e negaças, a possibilidade de orientação mais segura; as sensações relatadas apontam-se no registro dos órgãos sensoriais e, ao mesmo tempo, sugerem a anulação destes, do que resulta uma profusão de expressivos efeitos narrativos, à semelhança do oximoro em que se manifesta a expectativa fortemente tensionada da personagem: "Não vendo estranha coisa de se ver".

É verdade que certos sinais lançados pelo narrador na configuração dessa cena (por exemplo, a "mais-força", a "maior-coragem" extraída do "profundo mesmo da gente") fazem por vezes a representação ambígua pender com mais força para a dimensão subjetiva, isto é, a consumação da aliança com o "Satanás dos meus infernos". Há que se considerar, no entanto, que em grande parte é a reconstituição posterior do narrador que seleciona, organiza e elabora os indícios que apontam nessa direção. Envolto ainda na opacidade das vivências, o jagunço Riobaldo retorna das Veredas-Mortas trazendo em si a convicção de ter passado por uma experiência fundamental e, no fundo, inexprimível em palavras: "que isso não é falável. As coisas assim a gente mesmo não pega nem abarca. Cabem é no brilho da noite. Aragem do sagrado. Absolutas estrelas!”. Em última instância, essa experiência seria a consumação efetiva do pacto em meio à cena noturna. Um acordo tácito, afinal, não repugnaria à entidade que, ostentando também os nomes de "Calado" e "Sempre-sério", compraz-se em ocultar-se no "silêncio das astúcias". E ademais, quase quatrocentos anos após a pretensa façanha do doutor Fausto histórico, talvez já não seja mesmo necessário, como nos confessa Adrian Leverkühn em sua patética oratio de despedida, que a confirmação de um pacto diabólico se dê de maneira explícita: "Não penseis, meus caros irmãos e irmãs, que, para a promessa e o estabelecimento do pacto, eu tenha precisado de uma encruzilhada na floresta, de muito pentagrama mágico e conjuração grosseira, uma vez que já São Tomás ensina que, para a apostasia, não se carece de palavras propiciadoras da invocação, mas qualquer ato já é suficiente, mesmo sem homenagem explícita." (2010: 64)

Em meio, como aponta Mazzari, ao “jogo cambiante de afirmativas e negaças” típico do Grande sertão, tendo objetivamente o pacto diabólico se firmado ou não, a incursão às Veredas-Mortas manifesta-se como

${ }^{195}$ ROSA, João Guimarães. Primeiras estórias. “A terceira margem do rio”. $1^{\text {a }}$ edição especial. Rio de Janeiro: Nova Fronteira, 2005, p. 81. 
um epifânico momento de sagração, por Riobaldo, do ímpeto, da coragem, da objetividade e da ação. Nas palavras de Candido: “O demônio surge, então, como acicate permanente, estímulo para viver além do bem e do mal" (1991: 307). E, se em tempo de vaquejadal todo boi é barbatão, em tempo de guerra, de perseguição, de amor proibido, de ameaça, traição e caos no sertão, todo homem se torna bravio, arredio, irrequieto, selvagem, demoníaco, barbatão.

Riobaldo, outrora boi mocho, baetão, agora, com a doideira da boiada, com a traição do Hermógenes que, ainda nas palavras de Candido, "encarna o aspecto tenebroso da Cavalaria sertaneja - um cavaleiro felão, traidor do preito e da devoção tributadas ao suserano" -, com o iminente confrontar-se com seus demos e medos interiores, e com o suposto pacto - ou a crença nele -, virou o solto, o livre, o ousado e destemido Rei do Sertão.

O Sertão é a sombra minha/ e o rei dele é o Capitão!..., afirma, em seus versos, o aedo Urutu Branco, referindo-se a si mesmo, orgulhoso, decidido, e endossando seu poder, sua força, sua potência e prepotência, fazendo sombra até para o sertão - para o "Sertão" com inicial maiúscula -, do qual, agora, é rei e capitão ou melhor, é "Rei", com o "R" maiúsculo, como o termo fora grafado no último verso da quadra anterior da canção, e "Capitão", com “C” maiúsculo, trazendo, assim como fez para o sertão, atributo de nome próprio aos termos ou, mais do que isso, grafando-lhes com "maiúsculas alegorizantes", que fazem dos substantivos masculinos comuns "sertão", “cão", "rei” e "capitão", entidades, alegorias, alargando-lhes o espectro semântico e sugerindo-lhes possibilidades que ultrapassam as do genérico e generalizado substantivo comum em busca da categoria do absoluto, do essencial e até do transcendente.

Vale ressaltar, neste sentido, portanto, que os títulos de "Rei" ou de "Capitão" do "Sertão", alegorizados, mais do que uma conquista individual e humana do jagunço Riobaldo podem sugerir um compartilhar de "reinado" ou de "capitania", de chefia, com o transcendente e o metafísico, com o demo - o “Cão" - ou com Deus.

E o outrora tímido aprendiz de cantor que não demonstrava seus remidos versos para ninguém - que no momento exato do suposto pacto ainda só conseguira pedir para ficar sendo e, logo na sequência a ele, ao acreditado e desacreditado Trato, na dúvida entre Deus ou o demo, consciente de que seria capaz de ceder tudo o que era seu (alma e palma, e desalma) pedira, junto com Deus e o Demo, em dialética comunhão de opostos, para ser mais do que ele próprio ${ }^{196}$-, agora entoava sua canção à plena voz, para todos, entre todos, sobre todos, e com todos lhe fazendo coro. Ou melhor, todos, menos Diadorim. Na voz do próprio narrador: 196 O que eu agora queria! Ah, acho que o que era meu, mas que o desconhecido era, duvidável. Eu queria ser mais do que eu. Ah, eu queria,
eu podia. Carecia! "Deus ou o demo? - sofri um velho pensar. Mas, como era que eu queria, de que jeito, que? Feito o ar de meu ar, feito
tudo: que eu então havia de achar melhor morrer duma vez, caso que aquilo agora para mim náo fosse constituído. E em troca eu cedia às
arras, tudo meu, tudo o mais - alma e palma, e desalma... Deus e o Demo! (GSV, p. 437) - Nota-se nesse trecho da narrativa do GSV, mais 
Arte que cantei, e todas as cachaças. Depois os outros, à fanfa entoaram - mesmo sem entender, só por bazófias - mas rogando no estatuto daquela letra e retornando meu rompante; cantavam melhor cantando. De todos, menos vi Diadorim: ele era o em silêncios. (GSV, p. 480)

Com o silêncio de Diadorim - aparentemente não querendo fazer eco à nova canção de Riobaldo e a tudo o que ela simbolizava -, percebemos o novo chefe jagunço Urutu Branco, como o Fausto da tradição, vendo-se, mais e mais, do seu amor apartado:

Ao de que triste: e como eu ia poder levar em altos aquela tristeza? Aí - eu quis: feito a correnteza. Daí, não quis, não, de repentemente. Desde que eu era o chefe, assim eu via Diadorim de mim mais apartado. (GSV, p. 480)

Mas, se agora Riobaldo consegue passar, de repentemente, por cima de seus sentimentos por Diadorim, e das indecisões e frustrações que, feito um boi mocho, baetão, sempre o acompanharam; se, com o hipotético pacto - manipulação do mal para se atingir o bem possível num sertão onde bem e mal se misturam -, consegue tomar forças para trocar a contemplação pela ação, o remanso pela correnteza e a correnteza por um diferente e muito mais objetivo e calculado - frio - remansar, ainda assim persiste a ambiguidade: alma, coração e máquina motriz da narrativa de Grande sertão: veredas, síntese entre tese e antítese, oximoro, retrato de um sertão que é também, e ao mesmo tempo, Deus e demo, medo e coragem, o mundo e um homem, o dialético homem dos avessos.

Ambiguidade, mola mestra do "princípio geral da reversibilidade", como Candido tratou o "poder recíproco da terra e do homem", em Grande sertão: veredas. Princípio esse que dá "caráter fluido" e “misteriosa eficácia” à narrativa rosiana:

Ambiguidade da geografia, que desliza para o campo do lendário; ambiguidade dos tipos sociais, que participam da Cavalaria e do banditismo; ambiguidade afetiva, que faz o narrador oscilar, não apenas entre o amor sagrado de Otacília e o amor profano da 'militriz' Nhorinhá, mas entre a face permitida e a face interdita do amor, simbolizada na suprema ambiguidade da mulher-homem que é Diadorim; ambiguidade metafísica, que balança Riobaldo entre Deus e o Diabo, entre a realidade e a dúvida do pacto, dando-lhe o caráter de iniciado do mal para chegar ao bem. (1991: 205)

E essa ambiguidade aparece também nos versos de "continuação" da canção de Siruiz, pelo cerzir agora muito diferentemente lírico de Riobaldo: Hei-de amor em seus destinos/conforme o sim pelo não.

uma vez, a ênfase à complementariedade entre o "Bem" e o "Mal" presente, como já tratamos, não apenas no romance de Rosa, mas também no Livro de Jó, do Velho Testamento bíblico, e no Fausto, de Goethe. A respeito, merece nota um dos monólogos de Mefistófeles, no final do "Prólogo no céu": Vejo, uma outra vez, o Velho com prazer,/ Romper com Ele é que seria errôneo./ É, de um grande Senhor, louvável proceder/ Mostrar-se tão humano até pra com o demônio. (Goethe, 2001: 54). O jocoso Mefistófeles afirma que, de igual para igual, poderia até romper com Deus, mas não convém a ele - e a Ele - que o faça. 
O que antes era obrigação de incerteza e angústia, de dilaceramento e frustração, toda noite é rioabaixo/ todo dia é escuridão..., torna-se, após o Pacto, depois do suposto pacto, mesmo em permanente ambiguidade, mesmo conforme o sim pelo não, no habitual "jogo cambiante de afirmativas e negaças" de toda a travessia, não menos poder de decisão e de ação. Outra vez nas palavras de Candido:

O jagunço, sendo o homem adequado à terra ('O sertão é o jagunço') não poderia deixar de ser como é; mas, ao manipular o mal, como condição para atingir o bem possível no Sertão, transcende o estado de bandido. Bandido e não-bandido, portanto, é um ser ambivalente, que necessita revestir-se de certos poderes para definir a si mesmo. O pacto desempenha esta função na vida do narrador, cujo Eu, a partir desse momento, é de certo modo alienado em benefício do Nós, do grupo a que o indivíduo adere para ser livre no Sertão e que lhe consegue levar ao cumprimento da tarefa de aniquilar os traidores, os "Judas". Graças a isto é vencida, pelo menos na duração do ato, a ambiguidade do jagunço, que se fez integralmente paladino. (1991: 308)

Debruçando-nos um pouco mais sobre as minúcias dessa segunda canção de Riobaldo, de um "Eu” que Candido afirma alienar-se em benefício do "Nós”, deixando, árido e ressequido, de lado até, e principalmente, o "Tu" e o tipo de lírico e cortês amor a que esse "Tu" remete em nome de outros seus destinos de um desatinado amor, percebemos, no segundo verso da primeira quadra, a referência, em meio à ambígua geografia sertaneja, às veredas, no plural, onde o "trato com o Cão" foi supostamente firmado: Hei-de às armas, fechei trato/ nas veredas com o Cão.

É sabido que Riobaldo, em conversa com seu interlocutor forasteiro, denomina o local do presumível pacto com o diabo como o das Veredas-Mortas. Relembremos o primeiro relato do jagunço-narrador ao tratar do seu também primeiro encontro com esse lugar:

(...) Tudo é gerais... - eu pensei, por consolo. Um homem, que com a machadinha na mão e sua cabaça a tiracol tratava de desmelar cortiço num pau do mato, esse indicou tudo necessário e deu a menção de onde é que estávamos. $N a$ Coruja ${ }^{197}$, um retiro taperado. $E$ ali, redizendo o que foi meu primeiro pressentimento, eu ponho: que era por minha sina o lugar demarcado, começo de um grande penar em grandes pecados terríveis. Ali eu não devia nunca de me ter vindo; lá eu não devia de ter ficado. Foi o que assim de leve eu mesmo me disse, no avistar o redondo daquilo, e a velhice da casa. Que mesmo como coruja era - mas da orelhuda, mais mor, de tristes gargalhadas; porque a suindara é tão linda, nela tudo é cor que nem tem comparação nenhuma, por cima de riscas sedas de brancura. E aquele situado lugar não desmentia nenhuma tristeza. A vereda dele demorava uma aguinha chorada, demais. Até os buritis, mesmo, estavam presos. O que é que buriti diz? É: - Eu sei e não sei... Que é que o boi diz: - Me ensina o que eu sabia...

\footnotetext{
197 Já tratamos, em nota, do plural e ambíguo simbolismo que envolve a coruja com sua fama tétrica e sua capacidade de enxergar na escuridão. Câmara Cascudo, no Dicionário do Folclore Brasileiro, op. cit. p. 232, ressalta que, nos sertões brasileiros, essa fama sinistra das corujas se mantém: "Anunciam a morte, quando voam sobre a casa dos enfermos, e avisam desgraças, pela simples audição do canto lúgubre". E Cascudo acrescenta: "Quem come carne de coruja fica adivinhando o futuro." Vale lembrar que foi na Coruja que o bando de Zé Bebelo, no qual Riobaldo se inseria, sofreu o trágico surto de malária. E foi ali, também, que Riobaldo começou a ter os pressentimentos sobre sua sina funesta, a vislumbrar a necessidade do "pacto" e a enfrentar Zé Bebelo, transformando-se, aos poucos, em Urutu Branco e tomando para si a alcunha com que o próprio ex-chefe lhe apadrinhara.
} 
Bobice de todos. Só esta coisa o senhor guarde: meia-légua dali, um outro corgo-vereda, parado, sua água sem-cor por sobre de barro preto. Essas veredas eram duas, uma perto da outra; e logo depois, alargadas, formavam um tristonho brejão, tão fechado de moitas de plantas, tão apodrecido que em escuro: marimbus que não davam salvação. Elas tinham um nome conjunto - que eram as Veredas-Mortas. O senhor guarde bem. No meio do cerrado, ah, no meio do cerrado, para a gente dividir de lá ir, por uma ou por outra, se via uma encruzilhada. Agouro? Eu creio no temor de certos pontos. Tem, onde o senhor encosta a palma-da-mão em terra, e sua mão treme pra trás ou é a terra que treme se abaixando. A gente joga um punhado dela nas costas - e ela esquenta: aquele chão gostaria de comer o senhor; e ele cheira a outroras... Uma encruzilhada, e pois! - o senhor vá guardando... Aí mire e veja: as Veredas-Mortas... Ali eu tive limite certo. (GSV, p. 417 418)

Num tétrico retiro denominado Coruja, lugar demarcado entre o ali e o lá, e em meio a pressentimentos do começo de um grande penar em grandes pecados terríveis, Riobaldo, como na glosa que esclarece a canção de Siruiz, já tão tratada neste estudo, faz perguntas ao buriti e o que o buriti diz - e o que o jagunço recebe, por resposta, em complementariedade de opostos - é - Eu sei e não sei... E do boi, animal de predileção de Rosa e uma das mais fiéis representações simbólicas do próprio narrador de seu romance inclusive na canção de Siruiz e, após, nas quadras por ele mesmo compostas -, escuta: - Me ensina o que eu sabia... Na resposta do boi a uma pergunta sequer formulada, deparamos com um destino já sabido, todavia ainda não aprendido e apreendido, cifra a ser decifrada, como se tudo na vida do boi, de Riobaldo, dos buritis, já se soubesse antes, como se o próprio jagunço buscador, tal e qual quem come carne de coruja na tradição popular, pudesse antever o futuro, mas não soubesse, entre o sei e não sei, conforme o sim pelo não, como lidar com isso e, portanto, precisasse entender e aprender.

E o caminho da aprendizagem levaria o paladino-jagunço para meia-légua dali, para um outro corgovereda, parado, sua água sem-cor por sobre de barro preto, para um lugar em que, como um rio que não flui, córrego de águas paradas e sem cor, parece que o tempo parou, e o barro - de que Deus é o oleiro ${ }^{198}$ se empretejou.

Após, por mais cinco vezes no transcorrer da narrativa, Riobaldo trata do lugar com esse nome: Veredas-Mortas - também chamado Veredas-Tortas, num momento específico do romance em que aconselha seu interlocutor a não procurar por esse acreditado fatídico lugar ${ }^{199}$. Três vezes, ao narrar as anoitecidas horas do suposto pacto (GSV, p. 434 a 440). A quarta vez acontece no momento exato da narração da morte de Diadorim, após o duelo fatal com o Hermógenes e a descoberta de que o amado companheiro

\footnotetext{
198 Jó disse a Deus: “As tuas mãos me plasmaram ... Lembra-te de que me formaste como em barro” (Jó 10:8,9). Em Isaías, temos outras alusões bíblicas ao barro de que o homem foi, pelas mãos de Deus, moldado: "Ó SENHOR, tu és nosso Pai, nós somos o barro, e tu, o nosso oleiro; e todos nós, obra das tuas mãos” (Isaías 64:8).

${ }^{199}$ Rumo a rumo de lá, mas muito para baixo, é um lugar. Tem uma encruzilhada. Estradas vão para as Veredas Tortas - veredas mortas. Eu disse, o senhor não ouviu. Nem torne a falar nesse nome, não. É o que ao senhor lhe peço. Lugar não onde. Lugares assim são simples - dão nenhum aviso. Agora: quando passei por lá, minha mãe não tinha rezado - por mim naquele momento? (GSV, p. 113 )
} 
era, na verdade, uma mulher. E, com essa descoberta, percebemos novamente o trágico herói em seu desejo desesperado e "desapoderado" de voltar e de tentar, de alguma maneira, refazer as linhas do tempo e dos funestos destinos de si e de sua amada, desejo esse outrora tantas vezes já evidenciado, inclusive nos versos da canção de Siruiz Vim de lá, volto mais não.../ Vim de lá volto mais não?:

Desapoderei.

Aonde ia, eu retinha bem, mesmo na doidagem. A um lugar só: às Veredas-Mortas. De volta, de volta. Como se, tudo revendo, refazendo, eu pudesse receber outra vez o que não tinha tido, repor Diadorim em vida? ${ }^{200}$ (GSV, p. 616-617)

Por fim, a quinta aparição do nome Veredas-Mortas só surge no desfecho da narrativa e da travessia de Riobaldo. E, com ela, nós, leitores, temos, na voz do próprio narrador, uma surpresa provavelmente similar à que o próprio jagunço desesperado teve e viveu ao constatá-la: o nome dessas sinistras veredas, ao deusdar, era outro:

Eu vim. Pelejei. Ao deusdar. Como é que eu sabia destornar contra a minha tristeza? O dito, vim, consoante traçado. Num lugar, o Tuim, me alembro: eu tive de mudar para outro cavalo. E um sitiante, no Lambe-Mel, explicou-que o trecho, dos marimbus, aonde íamos, se chamava mais certo não era Veredas-Mortas, mas Veredas-Altas... Coisa que compadre meu Quelemém mais tarde me confirmou. Daí, mais para adiante, dei para tremer com uma febre. Terçã. Mas o sentido do tempo o senhor entende, resenha duma viagem. Cantar que o senhor fosse. (GSV, p. 617)

As Veredas-Mortas da narrativa, em verdade, como vimos no trecho do romance transcrito, acima, eram Veredas-Altas. Riobaldo constatou isso ao voltar ao lugar onde acreditava ter todo o seu funesto destino se configurado. E, percebendo que esse lugar não mais existia, pelo menos não na forma como o seu inconsciente anteriormente o viu e vivenciou, o nomeou, descobriu que não poderia receber outra vez o que não tinha tido e que tinha perdido, que não poderia voltar ao que não houve. Seu sábio compadre Quelemém, mais tarde, confirmaria a informação: de fato, o local chamava-se Veredas-Altas e não Veredas-Mortas e, portanto, ao menos na visão de Quelemén, pacto não havia ou, se havia, poderia ter sido feito é com Outro, mais "alto", menos "torto", que não o demo, e mais, ainda na voz de seu compadre e mestre espiritual: Comprar ou vender, às vezes, são as ações que são as quase iguais... (GSV, p. 623). Parodiando o dito popular, parece que, no Grande sertão: veredas, pelo menos seguindo os desígnios de Quelemém, Deus escreve certo por veredas tortas. Mas será que escreve mesmo?... O que é o certo e o que é o errado - ou o "torto" - na mítica e ambivalente geografia rosiana?...

\footnotetext{
${ }^{200}$ Percebe-se, aqui, o retorno à essencial indagação presente no quinto verso da canção de Siruiz, Vim de lá, volto mais não? que, como já tratamos, rompe com o equilíbrio formal e tradicional das típicas quadras das canções populares e, ao mesmo tempo, em oposição ao quarto verso, afirmativo, vim de lá, volto mais não..., propõe a quebra com a linearidade irreversível do tempo em nome de um desejo de voltar e de recuperar o que se perdeu.
} 
Como afirmou Candido, as ambiguidades do sertão não estão mesmo apenas nos homens, estão também na terra. As veredas do segundo verso da canção em análise, tão importantes para a geografia rosiana, para além de "mortas" ou "altas", são "mortas" e "altas", certos, tortos e "tênues canais de penetração e comunicação" entre os opostos complementares do sertão. Nas palavras de Paulo Rónai para explicar o título do romance:

\begin{abstract}
"[...] o "sertão" acaba sendo toda a confusão e tumultuosa massa do mundo sensível, caos ilimitado de que só uma parte ínfima nos é dado conhecer - precisamente a que se avista ao longo das "veredas", tênues canais de penetração e comunicação. Assim o sinal - : - entre os dois elementos do título teria valor adversativo, estabelecendo a oposição entre a imensa realidade inabrangível e suas mínimas parcelas acessíveis, ou, noutras palavras, entre o intuível e o conhecível." (2001: 17)
\end{abstract}

Utéza (1994:56) vê, porém, tal esclarecedora interpretação de Rónai sobre o título do romance em análise - e a importância da significação geográfica das veredas neste título e no universo rosiano -, ainda como em um demasiado "estágio dualista". Concordando com o crítico, mesmo endossando o indubitável valor da análise de Rónai, propomo-nos a ultrapassar essa concepção dualista e adversativa ou antitética polarizada - da relação entre sertão e veredas na perspectiva da Unidade: “O Grande sertão arquétipo implica as veredas, assim como as veredas supõem o Grande sertão", afirma Utéza e subscrevemos, nós, essa proposição. Aliás, vale ressaltar que não há, nas regras gramaticais, indício algum do sinal de dois pontos como o que aparece no título do romance - representando adversidade ou polarização. Geralmente esse sinal representa esclarecimento, enumeração, citação ou síntese do que foi escrito antes. E, para corroborar essa proposição, reproduzimos uma carta do próprio Rosa a Bizarri.

Em correspondência de 11 de outubro de 1963, Rosa explica pormenorizadamente ao seu tradutor italiano a importância do termo veredas não apenas na geografia física do sertão, mas também na constituição mítica e simbólica de sua obra - aliás, mais do que isso, o autor nos dá uma verdadeira aula de geografia sertaneja, demonstrando o seu profundo interesse pelo tema:

\title{
VEREDA
}

Você sabe, desde grande parte de Minas Gerais (Oeste e sobretudo Noroeste), aparecem os "campos gerais", ou "gerais" - paisagem geográfica que se estende pelo Oeste da Bahia, e Goiás (onde a palavra feminina: as gerais), até ao Piauí e ao Maranhão.

O que caracteriza esses GERAIS são as chapadas (planaltos, amplas elevações de terreno, chatas, às vezes serras mais ou menos tabulares) e os chapadões (grandes, imensas chapadas, às vezes séries de chapadas). São de terra péssima, vários tipos sobrepostos de arenito, infértil. (Brasília é uma típica chapada...) E tão poroso, que, quando bate chuva, não se forma lama nem se veem enxurradas, a água se infiltra, rápida, sem deixar vestígios, nem se vê, logo depois, que choveu. A vegetação é a do cerrado : as arvorezinhas tortas, baixas, enfezadas (só persistem porque têm longuíssimas raízes verticais, pivotantes, que mergulham a incríveis profundidades). E o capim, ali, é o áspero, de péssima qualidade, que, no 
reverdecer, no tempo das águas, cresce incrustado de areia, de partículas de sílica, como se fosse vidro moído : e adoece por isso, perigosamente, o gado que o come. Árvores, arbustos e má relva, são, nas chapadas, de um verde comum, feio, monótono.

Mas, por entre as chapadas, separando-as (ou, às vezes, mesmo no alto, em depressões no meio das chapadas) há as veredas. São vales de chão argiloso, onde aflora a água absorvida. Nas veredas, há sempre o buriti. De longe, a gente avista os buritis, e já sabe, lá se encontra água. A vereda é um oásis. Em relação às chapadas, elas são, as veredas, de belo verde-claro, aprazível, macio. O capim é verdinho-claro, bom. As veredas são férteis. Cheias de animais, de pássaros.

As encostas que descem das chapadas para as veredas são em geral muito úmidas, pedregosas (de pedrinhas pequenas no molhado chão claro), porejando aguinhas : chamam-se resfriados. O resfriado tem só uma grama rasteira, é nítida a mudança de aspectos da chapada para o resfriado e do resfriado para a vereda. Em geral, as estradas, na região, preferem ou precisam de ir, por motivos óbvios, contornando as chapadas, pelos resfriados, de vereda em vereda. (Aí, talvez, a etimologia da designação : vereda.)

Há veredas grandes e pequenas, compridas ou largas. Veredas com uma lagoa, com um brejo ou pântano, com pântanos de onde se formam e se vão escoando e crescendo as nascentes dos rios; com brejo grande, sujo, emaranhado de matagal (marimbú); com córrego, ribeirão ou riacho. (Por isso, também, em certas partes da região, passaram a chamar também de veredas ou ribeirões, riachos e córregos - para aumentar nossa confusão. (No começo do "Grande Sertão: Veredas" Riobaldo explica,)

Em geral, os moradores dos "gerais" ocupam as veredas, onde podem plantar roça e criar bois. São os veredeiros. Outros, moram mesmo no chão das chapadas, perto das veredinhas ou veredas altas, que, como disse, também há, nas chapadas : estes são os "geralistas" propriamente ditos (com relação aos veredeiros, isto é, em oposição aos veredeiros). Mas o nome de geralista abrange, igualmente, a todos : os veredeiros e os geralistas propriamente ditos. Quem mora nos gerais, seja em vereda ou chapada, é geralista. Eu, por exemplo. Você, agora, também.

Nas veredas há as vezes grandes matas, comuns. Mas, o centro, o íntimo vivinho e colorido da vereda, é sempre ornado de buritis, buritiranas, sassafrás e pindaíbas. As veredas são sempre belas! (BIZZARRI \& ROSA, 2003: 40-42)

“Tênues canais de penetração e comunicação" no sertão, as argilosas veredas - tantas vezes citadas no romance, inclusive em seu título, e retomadas na canção de Riobaldo - de onde aflora a água absorvida de todos os gerais, feito o caduceu de Hermes, são os elos de uma geografia una, todavia ambígua e ambivalente, que se retroalimenta de si e por si mesma.

As veredas, tidas por Rosa como o oásis do sertão, representam, na paisagem, como afirma Utéza, a “dominante fluida, sob forma de cursos d'água ou brejos reservatórios de germens de vida". Sintetizam a fluidez da vida sertaneja num universo poroso e ressequido não de polaridade, mas de complementariedade, de unidade complementar regida pelo "princípio da reversibilidade”, onde, feito as cobras entrelaçadas do caduceu hermético, em constante confronto, até o capim é perigoso, mas do qual, sob precisa e necessária tensão, brota toda a vida e o sustentável e possível caminho da vida. Voltando-nos à interpretação dos versos da canção, temos a síntese absoluta dessa ambivalência no conforme o sim pelo não. 
E, com a epistolar aula de geografia de Rosa a Bizzarri, compreendemos um pouco mais também do que são os "gerais" e do que representa a Travessia dos Gerais - com iniciais maiúsculas - do primeiro verso da terceira quadra da canção de Riobaldo. Atravessar os "gerais" é se deslocar, sobretudo, nas regiões Oeste e Noroeste do estado de Minas, nos chamados "campos gerais", ou "gerais", estendendo a travessia pelo Oeste da Bahia até Goiás, onde a palavra se torna feminina: "as gerais".

Merece uma breve retomada, aliás, pela própria voz de Riobaldo, a primeira aparição do termo "gerais" - no masculino - no romance e, com ela, a empolgada definição do narrador para o que esses "gerais" representam para sua saga jagunça, para a vida sertaneja e para a obra rosiana:

O Urucúia vem dos montões oestes. Mas, hoje, que na beira dele, tudo dá-fazendões de fazendas, almargem de vargens de bom render, as vazantes; culturas que vão de mata em mata, madeiras de grossura, até ainda virgens dessas lá há. O gerais corre em volta. Esses gerais são sem tamanho. (GSV, p. 24)

Muito já tratamos da importância do Urucuia e de sua geografia - real, mítica e simbólica - para a narrativa rosiana e para a saga riobaldiana. Pelas palavras de Utéza, é o rio Urucuia que dá sentido ao caos telúrico conjugado ao caos humano que o sertão representa:

“Ao longo de seu curso d'água, oriundo das altas terras do ocidente, surgem todas as manifestações de vida, desde a floresta virgem matricial até os embriões de cidade que são as grandes fazendas. Distribuidor das águas fecundantes, fonte energética, é o centro ativo à volta do qual a terra se torna fluida." (1994: 66)

E, se o Urucuia, representação simbólica da travessia e reflexo do próprio Riobaldo, dá sentido ao caos sertanejo, os "gerais" - no masculino plural -, sem tamanho, são o reino, a terra e os domínios desse rio, correndo em volta dele. Analisando, de modo comparativo, o trecho acima transcrito do romance e a primeira aparição, singular, do termo "gerais” na narrativa, Utéza nos apresenta uma instigante interpretação:

Sublinhado por itálicos no texto e determinado por um surpreendente singular, "o" Gerais, terra do Urucuia, erige-se em arquétipo, o que confirma o plural, conforme à norma gramatical, que lhe segue imediatamente: sem tamanho. Incomensurável, esse espaço contém tudo - gerais. Fora e dentro, margem esquerda e margem direita, singular e plural, montanha e vale, fértil e deserto, vazio e cheio, o sertão-gerais nada mais tem a ver com a geografia de Minas: O sertão está em toda parte. (1994: 66)

Durante quase todo o Grande sertão, o arquetípico termo "gerais", que contém tudo, é tratado no masculino, ora no singular, ora no plural, todavia, endossando a explicação da carta a Bizarri, há um momento em que ele é antecedido por artigo feminino no plural, o que diz respeito "às gerais" goianas ou, como diz Riobaldo, a essas gerais de Goiás: 
Pelo que, do trecho, voltamos. Para mais poente do que lá, só uruburetamas. E o caminho nosso era retornar por essas gerais de Goiás - como lá alguns falam. $O$ retornar para estes gerais de Minas Gerais. Para trás deixamos várzeas, cafundão, deixamos fechadas matas. O joão-congo piava cânticos, triste lá e ali em mim. Isto é, minto: hoje é triste, naquele tempo eram as alegrias. (GSV, p. 546)

Como Diadorim e Siruiz, "gerais", em Grande sertão: veredas, também se apresenta como um nome ambíguo, ambivalente de gêneros, "tudo", "todo" e "toda", representando, simultaneamente e em complementariedade, o masculino e o feminino ou o simbólico e mítico andrógino platônico - o hermafrodita alquímico, aliás, tão comum a tantos mitos originários -, de gênero indeterminado, e, portanto, apresentando as potencialidades de ambos os sexos, de ambas as vias, do todo e da toda em tudo. E vale lembrar que Riobaldo e seu bando só chegaram ao feminino de "gerais" - ou às gerais goianas ${ }^{201}$-, pouco antes do confronto final com os hermógenes e a descoberta de que Diadorim era, na verdade, a Diadorim. Por fim, não podemos nos esquecer de que esse confronto se deu no Paredão - vilarejo a dormitar na beira do Rio do Sono.

Diadorim era uma mulher. Diadorim era mulher como o sol não acende a água do rio Urucúia, como eu solucei meu desespero, nos esclarece, desesperado, assombrado e ensombrecido, o Urucuia Riobaldo que mirara e não vira, como se estivesse adormecido, por toda a travessia, o que aos seus olhos o sol, a todo tempo, iluminava e ofuscava, apagava e clareava. E essa descoberta se deu logo após, às margens do rio do Sono, ter presenciado, feito num redemoinho, feito em pesadelo, o confronto final, de morte - e de letal esquecimento -, entre sua amada Diadorim, seu amigo Reinaldo e o pactário Hermógenes, polarização inconcebivelmente trinária num confronto binário, tal e qual a também racionalmente inconcebível busca de uma "terceira margem do rio".

E, mesmo que o caminho de Riobaldo, após a morte do amigo e da amada, tenha se tornado insuportavelmente triste e sombreado, é preciso, pela voz do narrador, numa espécie de ritornelo, tentar voltar atrás e voltar-se sempre para trás, buscar "o” gerais supostamente conhecido, os gerais do Urucuia, os gerais da memória, para procurar ou almejar - quem sabe? - entender o acontecido, o sucedido, o não evitável, e para não se esquecer do que não pode e não deve ser esquecido.

Travessia dos Gerais/ tudo com armas na mão.../ O Sertão é a sombra minha/ e o rei dele é o Capitão!... - Mesmo com armas na mão, mesmo fazendo sombra até para o sertão e, sendo dele, rei e capitão

\footnotetext{
${ }^{201}$ Após a travessia do Liso do Sussuarão e a captura da mulher do Hermógenes, o Urutu Branco e seu bando partem da fazenda do inimigo, que é totalmente destruída, na divisa de Minas com a Bahia, ao norte, e dirigem-se para o oeste, divisa entre Minas e Goiás, em "um arco perfeito", como afirma VIGGIANO (2007: 56), rumando para o oeste e o poente e retornando para os gerais de Minas até o Paredão e o esconderijo dos hermógenes, mas não sem cruzar, antes, o Jalapão e as gerais goianas. UTÉZA (1994: 254) chama atenção para o fato de que Riobaldo fixou na memória apenas os aspectos femininos dessa "viagem de volta": “(...) paisagens côncavas com vegetação muito densa: várzeas, cafundão, fechadas matas."
} 
- ou supostamente dividindo esse reinado e essa chefia com o Cão... ou com Deus -, mesmo vencendo os hermógenes, Riobaldo não foi capaz de impedir a morte de Diadorim. Esquecer, para Riobaldo, era quase como perder dinheiro, ele já dizia, e o preço da vitória sobre os "judas", às margens do Rio do Sono - do letal esquecimento - foi alto demais. Não há como, simplesmente, acordar, despertar, desse letal pesadelo. Portanto, faz-se mister se lembrar dele e dos rumos que levaram - e o levaram - a ele, e, mais do que tudo, faz-se fundamental narrar e contar, sob a égide das Musas e da tradição oral, sua estória, tentando vencer o sono do esquecimento, um sono sem sonhos.

Como afirma Viggiano (2007: 39), o legendário rio do Sono ${ }^{202}$, além de compor o órfico cenário da batalha final contra o Hermógenes, é o palco de alguns dos mais emocionantes episódios do Grande sertão: veredas. Tratemos da importância desse rio no célere caminho de ascensão de Riobaldo até o comando dos jagunços e na própria narrativa de seu tempo de chefia.

Foi numa das margens do rio do Sono, num lugar chamado Marcavão ${ }^{203}$, que Medeiro Vaz morreu e que, pela primeira vez, foi ofertada a chefia do bando a Riobaldo - o qual, não se sentindo ainda preparado, não a aceitou. E, com o retorno de Zé Bebelo do exílio vivido nas gerais goianas, vindo este para vingar a morte de Joca Ramiro, seu outrora salvador, foi às margens do rio Soninho que o bando jagunço, no qual Riobaldo se incluía, chefiado ainda por Bebelo, travou graves lutas contra os hermógenes.

Vencidos os "judas" nas primeiras refregas, todos acreditavam que seria Zé Bebelo quem guiaria o bando até a batalha final contra Ricardão e o próprio Hermógenes, tornando-se o lendário e inesquecível chefe do exército jagunço que varreria o sertão do mal, iminente e eminente figura guerreira e política, mas isso não foi o que aconteceu. Após os primeiros combates sob sua liderança, Zé Bebelo mandou que todos retornassem, atravessando novamente o rio do Sono, em busca de mantimentos e reforço de munição na fazenda São Serafim ${ }^{204}$.

\footnotetext{
202 UTÉZA (1994: 245) associa o rio do Sono ao mítico rio grego Letes, o rio do esquecimento: "Assim o Paredão, pelo nome, assinala as profundezas infernais, como confirma aliás sua localização, nas beiras do rio do Sono - do Letes, o rio do esquecimento."

${ }^{203}$ A ser que, de campinas a campos, por morros, areiões e varjas, o Sesfredo e eu chegamos no Marcavão. Antes de lá, inchou o tempo, para chover. Chuva de desenraizar todo pau, tromba: chuvão que come terra, a gente vendo. Quem mede e pesa esses demais d'água? Rios foram se enchendo. Apeamos no Marcavão, beira do do-Sono. Medeiro Vaz morreu, naquele país fechado. (GSV,p. 94)

${ }^{204}$ UTÉZA (1994: 230) nota que Riobaldo relaciona a fazenda São Serafim com o próprio inferno. Fomos atrás, no romance, do trecho exato em que isso ocorre: Ainda, por suma vantagem disso, demos um tiroteio ganho, na fazenda São Serafim, dos diabos! (GSV, p. 113). Ao tratar como dos diabos o topônimo São Serafim, Utéza afirma: “(...) o narrador chama a atenção para a inadequação do nome da fazenda que, segundo ele, pelo contrário, devia ser consagrada aos sequazes de Satanás e não aos serafins: com efeito estes anjos pertencem à corte celestial e vivem em contato direto com Deus, no mais alto do Empíreo". Vale ressaltar, todavia, que, no mundo dos avessos de Rosa em que tudo é reversível, talvez esse nome não seja tão inadequado assim. De Chevalier e Gheerbrant (2000: 813-814), temos que Serafim significa o Abrasador (Saraf): "Isaias é o primeiro a mencionar anjos com esse nome (6, 2-3; 6-8): Acima dele, em pé, estavam serafins, cada um com seis asas: com duas cobriam a face (por medo de verem a Jeová), com duas cobriam os pés (eufemismo para designar o sexo) e com duas voavam. Estes clamavam uns para os outros e diziam: 'Santo, santo, santo é o Jeová dos Exércitos, a sua glória enche toda a terra...' Nisto, um dos serafins voou para junto de mim, trazendo na mão uma brasa que havia tirado, com uma tenaz, do altar. Com ela tocou-me os lábios e disse: 'Vê, isto tocou os teus lábios, a tua iniquidade está removida, o teu pecado está perdoado.' (...) A mesma raiz linguística sustenta uma evolução dupla: a evolução semântica do símbolo da queimadura; a evolução espiritual da consciência religiosa. Primitivamente, a queimadura era destinada a matar; depois,
} 
Na sequência, várias batalhas, em vai e vem - e, para a maioria dos jagunços, aparentemente sem sair do lugar - se travaram contra os hermógenes. Aí, Riobaldo, descontente com os mandos e desmandos de um Bebelo letárgico e com os rumos da guerra e de si mesmo, e tentando consertá-los e - de tortos - concertálos, já muito pensava e falava das Veredas-Tortas ou Veredas-Mortas:

\begin{abstract}
“(...) demos um tiroteio ganho, na fazenda São Serafim, dos diabos!
Rumo a rumo de lá, mas para baixo, é um lugar. Tem uma encruzilhada. Estradas vão para as Veredas Tortas - veredas mortas. Eu disse, o senhor não ouviu. Nem torne a falar nome, não. É o que ao senhor lhe peço. Lugar não onde. (GSV, p. 113)
\end{abstract}

Essas idas e vindas do bando margeando o rio do Sono, aparentemente sem fim e rumo certo, irritaram o outrora baldo narrador, que afirmava que se esquecer é quase como perder dinheiro (GSV, p. 423) e que começava, agora, diretivo, objetivo, fáustico, a despertar em si a dúvida a respeito da capacidade de liderança de Bebelo. Riobaldo e Diadorim queriam acabar logo com a guerra. Como já referido, desejavam fazer retas as linhas tortas e ir para cima do inimigo traidor.

Mas, sob o comando de Zé Bebelo, ao menos para o próprio chefe, ainda não era chegado o momento: Ao silêncio, Riobaldo Tatarana! Eh, eu sou o Chefe?! (GSV, p. 366) - Bebelo mais indagava do que afirmava. E o Tatarana, como uma lagarta de fogo, com sua pontaria certeira e já antevendo mutações, num vislumbre de asas, respondia: Pois é, Chefe. E eu sou nada. Não sou nada... Sou a coisinha nenhuma, o senhor sabe? Sou o nada coisinha mesmo nenhuma de nada, o menorzinho de todos. O senhor sabe? De nada... De nada... De nada...” (GSV, p. 366-367). Antevê-se nessas falas de Riobaldo, no que ele também mais perguntava do que afirmava a respeito dos supostos saberes - e poderes - de Bebelo, a disputa que, em breve, se daria pelo comando do grupo que se propunha a vingar Joca Ramiro e vencer o esquecimento. Quem, de fato, como Riobaldo cantava, era ou merecia ser o rei e o capitão do sertão? Quem deveria, às margens do rio do Sono, despertar e vencer o esquecimento e a letargia?

Zé Bebelo amolecia. Passado o episódio da fazenda dos Tucanos, onde, cercados pelos “judas”, com Riobaldo - já decidido a depor o chefe e só esperando a ocasião certa - desafiando Bebelo e recebendo dele a alcunha de Urutu Branco, o bando de jagunços segue para o Chapadão do Urucúia, onde todo boi berra e, enfrentando a bexiga, a malária, e o medo do ainda chefe em face da doença, sob a égide de estar em seu território, às margens do Urucuia, território seu, o até então Tatarana vai se tornando, de fato, mais e mais o designado Urutu Branco, nome que o acompanharia até o fim da saga jagunça. E é sob esse nome que, a

ela tem a finalidade de purificar". Portanto, a mesma chama que queima e mata pode também purificar e perdoar dos pecados, o que ressalta, mais uma vez, o caráter dúbio do suposto pacto de Riobaldo que, perto dali, ainda sob a égide de serafins, se firmaria. 
pouco e pouco, Riobaldo torna-se o novo líder guerreiro vingador de Joca Ramiro, depondo Bebelo e mandando-o para longe da cena da jagunçagem, para um outro esquecimento.

Mas, antes, e ainda sob a chefia - ao menos nominal - de Zé Bebelo, os jagunços perdem-se no caminho que os levaria a um lugar chamado Virgem-Mãe - confundido com outro, denominado Virgem da Lage - e, após passar pelo arraial dos Catrumanos, o Sucruiú, local flagelado pela bexiga preta, chegam a uma fazenda abandonada, de propriedade de um tal "seu Habão".

Nesse lugar, denominado o Valado, Riobaldo, doente de malária, resolve ficar por uns dias. Recuperado da febre e sentindo aí seu destino ${ }^{205}$, em face dos medos cada vez maiores de Zé Bebelo em relação ao povo do Sucruiú e aos riscos da bexiga, começa a fazer planos de chefia - planos de Rei e de Capitão, como canta sua canção. E é exatamente aí que o hábil dono da fazenda aparece e lhe presenteia com o seu indomável cavalo de estimação. Conhecedor das coisas e modos do sertão, sê̂ Habão já vislumbrava em Riobaldo o futuro líder dos cangaceiros. Na voz do próprio Riobaldo:

(...) por que seria que o sế Habão se engraçava de me presentear de repente com uma prenda dum valor desse, eu que não era amigo nem parente dele, que não me devia obrigação, quase que nem me conhecia? Aos que projetos ele engenhava em sua mente, que possança minha ele adivinhava? (GSV, p. 447)

Um dos jagunços caçoou de Riobaldo ao lhe perguntar a respeito do nome que o belo e indômito alazão receberia: - Ara, que assim ouvi, Tatarana: o nome que ele vai se chamar é mesmo Barzabu? No que Riobaldo, em regozijo, orgulhoso, lhe responde de pronto: - A não, meu compadre torto! Sossega a velha... Nome que dou a ele, d'ora em diante, conferido, é este - quem que aprender, aprende! - que é: o cavalo Siruiz!.. (GSV, p. 447)

Em posse das rédeas do cavalo recém-nomeado Siruiz, montando o animal outrora jamais montado e dando as costas a Zé Bebelo, Riobaldo deixava para trás seus tempos de Tatarana. A metamorfose se consumara, plena, agora era o Urutu Branco, o Capitão, e, assim como nomeara e domara o Siruiz, podia compor suas próprias quadras, cantar seu próprio destino. Podia ser mesmo o Rei do Sertão: Agora, o tempo de todas as doideiras estava bicho livre para principiar. (GSV, p. 455)

Para Utéza (1994: 234), porém, desde a noite das Veredas-Mortas, Riobaldo, agora como chefe Urutu Branco, não é tão dono de seus atos e das rédeas de seu destino assim. Ele segue, instintivamente, os rumos escolhidos pelo cavalo Siruiz, o que indicaria que, independente de ele se tornar o compositor de seus próprios

${ }^{205}$ E ali, redizendo o que foi o primeiro pressentimento, eu ponho: que era por minha sina o lugar demarcado, começo de um grande penar em grandes pecados terríveis. Ali eu não devia nunca de me ter vindo; lá, eu não devia de ter ficado. (GSV, p.417) 
versos, as "forças cósmicas” - fazendo uso da expressão de Utéza - ou o destino, representados pela canção de Siruiz, continuariam ainda a reger a sua vida e sua travessia.

E a aparente doideira expressada na canção de Riobaldo talvez não fosse tão doida assim: no centro do sertão, o que é doideira às vezes pode ser a razão mais certa e de mais juízo! (GSV, p. 301) - reafirmou o jagunço, entre tantas reflexões e digressões, as leis do sertão, e as leis de Siruiz. E, noutro momento, ainda na voz do narrador, a aparente ajuizada doideira com que conduzia as rédeas de Siruiz - ou se deixava conduzir por elas - se mostra ainda mais clara:

(...) já estava inteirado no comum, nas meias-alegrias: a meia-bondade misturada com maldade a meio. Agora levantava, puxava e arreava meu Siruiz, cavalo para alvoradas. Saía sozinho. (GSV, p. 507) (...) Demos o demo... E possuía era meu caminho, nos peitos de meu cavalo. Siruiz. Aleluia só. (GSV, p. 536).

No confronto final da batalha do Tamanduá-tão, podemos perceber a representação máxima, auge e ápice, da relação entre o Urutu Branco - suposto pactário -, seu cavalo Siruiz e o Sertão - também sertão de Siruiz - a quem faz, nesse momento, sombra e do qual, como afirma sua canção, tornara-se Rei e Capitão:

(...) todo o todo do Tamanduá-tão se alastrou em fogo de guerra.

Suspenso - ouviu? - escapei, à de banda, com meu bom cavalo, repuxei as rédeas. Só assim permaneci, eu estava debaixo duma árvore muito galhosa; canjoão? Que pensei. $E$ rompeu tiro, romperam, na polvorada. Até o capim dava assovio. E, por tudo se desejar de ver, tantamente demorava e ficava custoso, para em alguma justa coisa se afirmar os olhos. O que era feito grande mesa posta, cujos luxos motivos, por dizer, alguém puxa a toalha e, vai, derruba... Quem era que ia poder botar naquilo uma ordem, para um fim com vitória? E estralou bala... Repisei em minhas estribeiras, apertei as pernas nas espendas. Eu tinha de comandar. Eu estava sozinho! Eu mesmo, mim, não guerreei. Sou Zé Bebelo?! Permaneci. Eu podia tudo ver, com friezas, escorrido de todo medo. Nem ira eu tinha. A minha raiva já estava abalada. E mesmo, ver, tão em embaralhado, de que é que me servia? Conservei em punho meu revólver, mas cruzei os braços. Fechei os olhos. Só com o constante poder de minhas pernas, eu ensinava a quietidão a Siruiz meu cavalo. E tudo perpassante perpassou. $O$ que eu tinha, que era a minha parte, era isso: eu comandar. Talmente eu podia lá ir, com todos me misturar, enviar por? Não! Só comandei. Comandei o mundo, que desmanchando todo estavam. Que comandar é só assim: ficar quieto e ter mais coragem. (GSV, p. 569-570)

Ensinando a quietude ao seu cavalo e a seu destino - ou aprendendo com eles -, sem apear, sem dar um tiro sequer, guerreando sem guerrear - feito um portador dos valores da antiga filosofia dos Budôs orientais, que colocavam a superioridade do espírito sobre a força bruta e os inimigos externos como projeção dos internos, ou feito um monge Zen que se propunha a guerrear sem armas, intermediário do influxo cósmico e movido somente pelas forças do espírito -, apenas comandando, sozinho, sob a proteção duma árvore 
muito galhosa - canjoão $^{206}$ ? - e, mais, com a coragem e a força de sua vontade -, sem titubeios e com muita baldanza, o Urutu Branco venceria a guerra do Tamanduá-tão:

(...) À fé, que fiz. Se não vivei Deus, ah, também com o demo não me peguei-refiro; mas um nome só eu falava, fortemente falado baixo, e que pensado com mais força ainda. $E$ que era: - Urutú Branco!... Urutú Branco!... Urutú Branco!... Cujo era eu mesmo. Eu sabia, eu queria. (GSV, p. 570)

Todavia, mesmo falando baixo e clamando só pelo Urutu Branco de si mesmo, e mesmo acreditando contar apenas consigo e com sua própria vontade e coragem, "sabendo, querendo", parece que ainda assim havia algo ou alguém - "Alguém”, com inicial maiúscula, feito também um Rei ou um Capitão, ou feito o próprio Deus, o apóstolo São João ou o famigerado $\boldsymbol{C} \tilde{a} \boldsymbol{o}$ - a mais com quem podia e poderia - acreditava em poder - contar:

E quando a guerra para o meu lado relambeu, feito repentina labareda dum fogo. Uns vieram. E os tiros - deles, - bala batia e rebatia. Cortavam capim do chão, que riscavam com punhado de terra. Tch'avam partes de ramos da árvore por cima de mim, e vagens do angico, que então reconheci por isso. Como quieto fiquei. Eu não era o chefe? Mesmo que uma carga de rifle se passou em meu chapéu-de-couro-de-vaca, e que outra, zoante, em meu jaleco raspou. A mil, que não movi mão, mas dei desprezo. Mas, eu tivesse alargado braço e movido mão, para com tiros de meu revólver ripostar, e eu mal morto estava ponto que enquadrado de passantes balas, que rentes, até quentes. - Urutú Branco... - eu só relembrei, sussurrado ditoso, como quando com mocinha meiga se namora. Cachaças que em minha alegria. Em vento. E balas, mais, só; num enorme num minuto. Mas, bem: que, aluir dali, eu não aluía. Morresse - tive preguiça de pensar-mas, morresse, então morria três-em-pé, de valente: como o homem maior valente no mundo todo, e na hora mais alta de sua maior valentia! À fé, que foi. Dei em lagoa, de tão filho tranquilo... (GSV, p. 570-571)

De corpo fechado, à fé, que foi, como que protegido por uma entidade superior - ou inferior num mundo em que os opostos se espelham, se complementam e se revertem -, nenhuma bala atingia ou poderia atingir

\footnotetext{
206 O canjoão, Senna acuruensis ou Cassia acuruensis, é uma árvore endêmica da região da caatinga baiana, encontrada também nos sertões mineiros. É chamada ainda de canela-velha, besouro, e, segundo o dicionário Caudas Aulete, de São João e São Joãozinho. Nota-se no nome canjoão a possibilidade de leitura como uma composição por aglutinação de com + João, o que levaria à possibilidade de uma interpretação do trecho como estando Riobaldo, no auge da guerra do Tamanduá-tão, sob a proteção de São João - com + João. Segundo VARAZZE, Jacopo de, in: Legenda áurea - vidas de santos, João significa "graça de Deus", ou "em quem está a graça", ou " ao qual foi dada a graça", ou " aquele que recebeu um dom de Deus": "Daí os quatro privilégios recebidos pelo bem-aventurado João. O primeiro foi a predileção que Cristo dedicava a ele. De fato, Cristo amou-o mais que aos outros apóstolos e deu a ele as maiores provas de afeto e familiaridade. Assim, 'graça de Deus' porque foi gracioso a Deus. (...) O segundo privilégio é a incorrupção da carne, pois ele era virgem quando foi escolhido pelo Senhor. Assim, 'nele está a graça' refere-se à graça da pureza virginal, pois queria se casar quando foi chamado pelo Senhor. O terceiro privilégio é a revelação de mistérios concernentes à Divindade do Verbo e ao fim do mundo, daí 'ao qual foi dada a graça'. O quarto privilégio é ter sido encarregado de cuidar da mãe de Deus. Assim, pode-se dizer que 'recebeu um dom de Deus', já que o maior presente que o Senhor podia dar era confiar-lhe sua mãe” (p. 113). Refazendo os cálculos da cronologia do Grande sertão, propostos por Utéza, a partir da informação lançada por voz anônima na chegada do bando de Riobaldo à fazenda Barbaranha - De uns três dias foi o São João, então amanhã é São Pedro... (GSV, p. 467) -, o suposto pacto das Veredas-Mortas se deu na Noite de São João, na passagem do sábado, dia 23, para o domingo, dia 24 de junho. (1994: 199), constatando-se isso, não é de se espantar, a proteção do canjoão ou o compartilhar da graça e do dom de São João. Vale lembrar, por fim, que o Evangelho de São João sempre foi o predileto dos estudiosos de misticismo e de hermetismo.
} 
o tranquilo Riobaldo, na hora mais alta de sua maior valentia. Se morresse, então morria três-em-pé, de valente: como o homem maior valente no mundo todo, como um Rei e um Capitão - como o Cão ou como alguém que, com ele, mal ou bem, como o Fausto, como Jó, pactuou - consciente disso ou não - uma nova trindade: o três-em-pé composto por um homem, Deus e o diabo; o pai, o filho e o santo - demoníaco espírito da ação.

E Riobaldo não morreu. Erguido no cavalo que também se imobilizou, calmo feito em lagoa e sob a égide do canjoão e da canção, o chefe fez o sinal-da-cruz, colocando-se sob a proteção também de um símbolo que sua tradição sertaneja e cristã situa do lado do bem, do grande Bem, e, como afirma Utéza (1994: 243), realizando na sua pessoa um "rito de orientação, sacralizando-se no exato momento em que - retomando os princípios do Budô -, o macrocosmos começa a se movimentar em consequência do impulso que ele próprio, Urutu Branco, deu ao lançar seus cavaleiros”. Nas palavras do próprio Riobaldo:

(...) fiz o sinal-da-cruz, em respeito. E isso era de pactário? Era de filho do demo? Tanto que não; renego! E mesmo me alembro do que se deu, por mim: que eu estava crente, forte, que, do demo, do Cão sem açamo, quem era ele - o Hermógenes! Mas com o arrojo de Deus eu queria estar, eu não estava?! (GSV, p. 569)

Para Utéza, o alcance do gesto de Riobaldo ultrapassa, mais uma vez, a perspectiva restrita do Bem e do Mal: “(...) com o sinal-da-cruz o chefe fixa no centro da sua pessoa, que se vai projetando para cima, a fonte das energias centrífugas que empurravam vargem adentro o Fafafa com seus cavaleiros” (p. 243).

Em torno de um eixo ternário materializado na figura do canjoão, do chefe Urutu Branco e seu cavalo, feito o próprio centro imóvel de um redemoinho, os jagunços dançam, em espiral, o bailado da guerra e, como já vimos, nada atinge ou pode atingir Riobaldo. O chefe não morre. Não pode morrer. E, noutro momento de sua travessia, com o diabo na rua, haverá outro - outra -, outro e outra, para morrer por ele e para, nas contabilidades do Sertão, tentar quitar a sua dívida. Dívida essa, entretanto, que, nas voltas que o mundo dá, mesmo estando no meio do redemoinho, nunca de todo se poderia ou se poderá apartar ou quitar.

O Paredão, segundo Utéza, assinala e representa as “profundezas infernais". Riobaldo teria que, feito Orfeu ou Hermes, feito o próprio Dante da Divina Comédia - ou o jovem que morreu trinta dias após o casamento e, segundo a Legenda áurea (p. 116), foi ressuscitado e trazido de volta do Inferno pelo apóstolo João -, descer aos subterrâneos do mundo - ao Hades ou ao Inferno - para poder voltar. Todavia, para voltar sozinho, sem Eurídice, sem Beatriz, sem Diadorim. 
Para endossar sua tese sobre o simbolismo do Paredão, Utéza cita as pesquisas de Viggiano ${ }^{207}$ e a localização geográfica do lugar, como já afirmamos, nas beiras do rio do Sono - do Letes, o rio do esquecimento - e, tratando do chamado aos Céus típico das míticas ou religiosas descidas aos infernos, acrescenta:

Pela topografia, ergue-se no céu o chamamento vertical do sobrado, seu edifício mais imponente, plantado no meio da horizontal materializada pela única rua. Perfila-se aqui mais uma vez a união dos contrários no símbolo supremo da cruz, enquanto os jagunços se dirigem para o Oriente: Íamos rodeando resolutamente, dando as costas para o sol-entrando. (1994: 245)

E foi o sobrado, eixo central e ponto mais alto - e mais próximo do Céu - do vilarejo do Paredão, numa espécie de torre medieval, símbolo de ascensão e vigilância, o local intuído por Riobaldo - e sugerido por Diadorim - para fixar sua chefia, sua "capitania", de Rei do Sertão e para tentar colocar ordem no caos, nortear a doideira da boiada em que se tornara a realidade sertaneja após a traição de Joca Ramiro pelos "judas":

Com ansêio, olhei, para muito ver, o sobrado rico da banda da mão direita da rua, com suas portas e janelas pintadas de azul, tão bem esquadriadas. Aquela era a residência alta do Paredão, soberana das outras (...) Aquele sobrado, sobradão, parava lá, sobre sereno me prazia todo comandando. (GSV, p. 598)

Assim interpreta Utéza a intuição do paladino Riobaldo ao avistar a torre:

A intuição do jagunço que aspira reassumir a antiga chefia identifica aquela Torre como adequada ao exercício do comando: a partir daquele Eixo do Mundo, ele poderia ordenar no plano contingente o caos que resultara do ataque do Hermógenes e, no absoluto, reger a globalidade do movimento giratório universal. (1994: 246)

Voltemo-nos, agora, à própria narrativa do romance para observarmos o momento exato da escolha do sobrado como eixo e centro das decisões da guerra no Paredão e para evidenciarmos a importância da interferência do desejo de Diadorim para essa escolha e para os rumos que o destino dará às cenas subsequentes a ela.

Logo após avistar o sobrado e intuir que ali seria uma boa torre de comando, Riobaldo titubeia: Ir lá?... É Diadorim que o aconselha: - “Pouco é, para ações. Tu vai lá, Riobaldo...”. Mas o Urutu Branco, em baldo momento, ou pressentindo alguma coisa que o imobilizava - ou, talvez, quisesse imobilizá-lo -, ainda titubeou, retrucou:

${ }^{207}$ VIGGIANO, Alan. "Paredão de Minas: onde o sertão acaba". Nesta reportagem de O Estado de Minas, Belo Horizonte, 9 de janeiro de 1985 , o pesquisador explica o nome do lugar pela presença, no povoado, de uma grande parede de tijolos. 
- “Aqui é que é meu dever, Diadorim. Por o mais perigoso...”-eu falei, muito alerta. Tudo que Diadorim aconselhasse, eu punha de remissa; a modo de que com pressentimentos. (GSV, p. 599)

Entretanto, tal como predizia a canção de Siruiz, que colocava Riobaldo sempre correndo os dias nesses verdes que são os orvalhados olhos da padroeira Diadorim, mesmo em tempos de Urutu Branco, não tardaria para o amado companheiro dissuadi-lo de sua decisão de ação:

- "Tu vai, Riobaldo. Acolá no alto, é que o lugar de chefe. Com teu dever, pela pontaria mestra: que lá em riba, de lá tu mais alcança... Constante que, aqui, o negócio está garantido..."-ele disse, mansinho, de me persuadir. (GSV, p. 599)

No antes e no depois do "pacto", no antes e no depois da doideira na boiada, Gabriela Reinaldo (2005), com quem o tempo todo dialogamos neste trabalho, separa e afasta, contrapondo as canções do Grande sertão - a de Siruiz, as de Riobaldo - e seus contextos:

Em Grande sertão há a estúrdia cantiga de Siruiz, que convida o herói a buscar o amor, amor espiritual, a moça virgem, a padroeira que guiará o herói em sua aventura. E também o canto do homem, do jagunço Riobaldo, canto desarranjado, embolado, que alude à guerra, à precisão, à necessidade [...] O canto da guerra é o canto das armas - lava com ponta de faca e com bala de canhão ${ }^{208}$ - da doideira - deu doideira na boiada - o desentoar da cantiga, destemperada, da dansasão e desordem, do pacto, do caos, do diabo. É o canto que hipnotiza. (p. 188-189)

Todavia, percebendo a influência da moça virgem Diadorim sobre o jagunço, notamos que no "mundo misturado" que é o sertão rosiano, onde, como afirma a própria Reinaldo, "o feio não se aparta do bonito e a alegria se avizinha da tristeza, onde o preto contém o branco e a ruindade é o germe da bondade” (p. 193), onde o que é doideira às vezes pode ser a razão mais certa e de maior juízo (GSV, p. 301), não há como se apartar uma canção de outra ou uma busca de outra, elas se espelham e, tal trevas e luz, são opostos complementares. E Riobaldo, numa ou noutras, por mais que esteja ou não com as rédeas de seu cavalo Siruiz nas mãos, por mais que se creia pactário, está sempre sendo guiado por sua padroeira e pela encantada toada de Siruiz.

O Tatarana, movido pelos olhos do amado companheiro, mirou e admirou o sobrado. Refletiu: $\mathbf{M e u}$ posto? Após, olhou novamente para Diadorim que, firme diante dele se mostrava e se ocultava, firme feito veada-mãe que vem aparecer e refugir, de propósito, em chamariz de finta, para a gente não dar com o veadinho filhote onde é que está amoitado... (GSV, p. 599), E, por fim, tomou a decisão - ou se deixou tomar por ela:

\footnotetext{
${ }^{208}$ Vide o canto de guerra de Augusto Matraga, in: ROSA, João Guimarães. “A hora e a vez de Augusto Matraga”. Sagarana. 55a impressão. Rio de Janeiro: Nova Fronteira, 2001.
} 


\section{Aquele sobrado era a torre. Assumido superior nas alturas dele, é que era para um chefe comandar - reger o todo cantão de guerra! \\ - “Eu vou..." - fui. (GSV, p. 599)}

Sim, a torre era o lugar mais adequado para o Urutu Branco. Para o Capitão que pretendia subjugar o Hermógenes, vingar Joca Ramiro e, após, colocar ordem na doideira na boiada, no caos instaurado pelos hermógenes, e se tornar, de fato, o Rei de todo o Sertão, fazendo-lhe sombra, varrendo-lhe do maior mal, aquele destinado ao nono e último círculo ${ }^{209}$ do Inferno de Dante: o da traição. E, após - quem sabe? - além do bem e do mal, vencendo os circulares labirintos infernais e os designíos de Hades, aproximando ainda mais cantos e versos, poderia, elevado, compartilhar esse reinado com quem bem aprouvesse, inclusive com Diadorim, sem ocultações, sem subterfúgios, sem neblina.

Antes do assassinato de Joca Ramiro, Riobaldo e Diadorim passaram dois meses felizes no Guararavacã do Guacuí, paraíso perdido, éden idílico, um “espaço ideal ao lado do amigo ideal e da mulher ideal” - como afirma Utéza.

O lírico e cordial jagunço Riobaldo acreditava que derrotar os "judas" e matar o Hermógenes eram o preço necessário para se reconquistar a felicidade perdida. Pretendia vencer a doideira de um sertão desvirtuado em que toda rês precisa ser bravia, todo boi é barbatão, para voltar, no tempo e no espaço, e poder apreciar, junto a Reinaldo, junto a Diadorim, no meio das croas - de elevações de terra que emergem das águas dos rios em tempos de vazante -, o bailado e o canto dos pássaros. Voltar a escutar, serenado, a linguagem de seres alados que aprendeu, com o amado amigo, a amar - dentre os quais, e principalmente, $\mathrm{o}$ manuelzinho-da-croa ${ }^{210}$, que parecia andar por sobre as águas e que, sempre em casal, representava a quintessência do amor: o passarinho lindo de mais amor. (GSV, p. 604).

Em "São Marcos", conto de Sagarana no qual o protagonista está envolvido em uma teia de fé, amavios e magia produzidos e evocados pelo poder da palavra, afirma o narrador: "E não é sem assim que as palavras têm canto e plumagem.". Em "Cara-de-Bronze", de Corpo de baile, o vaqueiro Abel responde ao vaqueiro Noró que "Canto de passarim? É quando ele tira para pensar alto...". Em "A hora e a vez de Augusto Matraga", outro conto de Sagarana, a algaravia dos pássaros soa como uma convocação dos céus para Augusto. No último de seus livros de contos, publicado postumamente, Guimarães Rosa saúda a altura que

\footnotetext{
${ }^{209}$ Vale lembrar que, neste círculo, os rios do inferno - Aqueronte, Estige e Flegetonte - deságuam e formam o lago Cocito, totalmente congelado. No fundo deste lago, encontramos Lúcifer preso ao gelo, com grandiosas asas e três cabeças, mastigando em cada boca um dos três maiores traidores da história ocidental até os tempos de Dante: Judas, Brutus e Cássio. O Inferno de Dante é resultado da queda de Lúcifer, por isso é afunilado desde a superfície até o centro terrestre, ou seja, em círculos concêntricos para o fundo e para dentro, o contrário do Paraíso, representado para cima e para fora.

${ }^{210} \mathrm{O}$ nome Manuel deriva de Emanuel, do hebraico Immanuel, composto pelos elementos immánu, que significa "conosco" e El, que quer dizer "Deus" ou "Senhor" e significa "Deus está conosco" ou "Deus conosco".
} 
as palavras, pelo voo e pelo cantar dos pássaros, pode alcançar: Ave, palavra. No Grande sertão não seria diferente: canto dos pássaros, voz do alto.

Afirma Reinaldo (2005):

"Em suas digressões sobre a palavra, para dizer da força do nome, força mágica, epifânica, poética do logos, Rosa usa a alegoria do pássaro [...] Em Grande sertão, o manuelzinho-dacroa, pássaro de predileção de Diadorim, está entre as principais lembranças de Riobaldo, junto às coisas mais importantes de sua vida, como o amor, a cantiga de Siruiz, as lembranças de sua mãe, de sua Nossa Senhora da Abadia. Recordações de fio sirgo (sirgo é o nome que se dá ao bicho da seda), que lhe fazem garimpar as melhores coisas em si mesmo: "No fio sirgo dessas recordações, eu acho que eu bateava outra espécie de bondade.” (p. 183)

Mas como tecer fios de seda em meio à doideira na boiada. Como dar voz aos pássaros em face do caos e do alvoroço dos tiros, urros, berros, dos gritos de dor e das arruaças da guerra?... Para que Siruiz ${ }^{211}$ pudesse voltar a cantar, pudesse retornar à lembrança de todos, vencendo Letes e o sono, despertando-os, elevando-os, e, novamente, quebrando barras, era preciso que o sertão silenciasse novamente. No meio da guerra, o Urutu Branco só conseguia ouvir "cantigas desentoadas" ${ }^{212}$, cantos de raiva, de sangue fervendo, de balas zunindo, e a torre poderia ajudá-lo a ver tudo de cima, a ouvir do alto, a estar mais próximo dos pássaros e de Deus, e a encontrar a elevação e o esclarecimento necessários para a chefia e para a busca do caminho que devolvesse o sertão à ordem e Reinaldo Diadorim a Riobaldo. Aceitou o conselho do companheiro e rumou ao sobrado, elevando-se ao alto e postando-se em uma de suas janelas, fazendo planos para o final do combate:

\section{Então, eu podia, revia:}

- ...Mas, porém, quando isto tudo findar, Diá, Di, então, quando eu casar, tu deve de vir viver em companhia com a gente, numa fazenda, em boa beira do Urucúia... O Urucúia, perto da barra, também tem belas croas de areia, e ilhas que forma, com verdes árvores debruçadas. E a lá se dão os pássaros: de todos os mesmos prazentes pássaros do Rio das Velhas, da saudade - jaburú e galinhol e garça-branca, a garça-rosada que repassa em extensos no ar, feito vestido de mulher... E o manuelzinho-da-crôa, que pisa e se desempenha tão catita - o manuelzinho não é mesmo de todos o passarinho lindo de mais amor?...

Podia ser? Impossivelmente. (GSV, p. 604)

${ }^{211}$ REINALDO (2005: 184) relaciona a palavra Siruiz com o rouxinol:

Decompondo-se o nome do cantor de Grande sertão, Siruiz, têm-se algo como Sir Ruiz, o senhor Ruiz. O que se assemelha ao termo rouxinol em espanhol: ruiseñor. (...) A "pouca carne", a falta de materialidade palpável do rouxinol - pássaro universalmente apreciado pela perfeição do canto, ligado à morte e ao amor, como na peça Romeu e Julieta, de Shakespeare - é assim como Siruiz, "uma voz e mais nada". Além de em Shakespeare, o rouxinol e seu canto virtuoso está presente em inúmeras obras como a Odisseia, de Homero, e "Orfeu”, de Vírgílio. Nesta, Virgílio compara o luto de Orfeu com o "lamento" do Rouxinol.

${ }^{212}$ A gente ouvia a urração, ou cita seja, destemperada, dos inimigos, e um desentoar da cantiga, que toda a pessoa era filho-da, segundo a qual." (GSV, p. 600) 
E foi da alta janela da torre, representada pelo sobrado, entre tiros e impossíveis ponderações sobre o que poderia ter dito a Diadorim e não disse, sobre o que poderia ter feito com o companheiro e não fez, sobre o que poderia ter vivido e não viveu, que Riobaldo teve a pior visão de sua vida: viu o Diabo na rua, no meio do redemunho... (GSV, p. 610)

Segundo Chevalier e Gheerbrant (2000: 773), o redemoinho, devido ao seu movimento helicoidal, simboliza, nas mais diversas tradições e culturas, uma evolução. Todavia não uma evolução qualquer, mas sim aquela que é incontrolada pelos homens e dirigida por forças superiores ou transcendentais, e os estudiosos de símbolos acrescentam: "Pode haver a dupla significação de queda no redemoinho ou de redemoinho ascensional, de regressão irresistível ou de progresso acelerado. Mas caracteriza, pela sua violência, uma extraordinária intervenção no decurso das coisas."

Cascudo também analisou a importância simbólica do redemoinho para a nossa cultura e para a tradição popular:

O remoinho é o vento em espiral, rodando como um parafuso gigantesco. Tem vida própria e atende às intercessões divinas. A origem, diz o povo, é o encontro de dois ventos. Briga de ventos, duelo, vadiação (...) Quando se produz um redemoinho de vento, a que o povo da Beira Alta e noutras partes chama borborinho, acredita-se que anda no ar o diabo, ou bruxas ou qualquer cousa má. Para estes seres fugirem, faz-se uma cruz com a mão, ou diz-se Credo, santo nome de Jesus. (...) O povo foge dele, mas como que o vai seguindo, dizendo: Santo nome de Jesus! Credo! Abrenuntio! mas, principalmente: Vai-te para quem te comeu as leiras! Fazem-lhes cruzes e acompanham depois com a vista a queda das palhas levantadas pelo vento: onde elas caem, cuida-se que foi o sítio em que houve roubo de terra. (...) Em Guimarães ouvi dizer que, quando o borborinho levanta muitas folhas, vai um diabo em cada folha. (2012: 607-608)

O redemoinho do Grande sertão passou e não foram apenas dois ventos que duelaram ou que se encontraram, nem somente folhas e palhas que restaram, após o burburinho, caídas no chão. De sua incontrolável violência, ficaram dois corpos: o do Hermógenes, o de Diadorim. Opostos complementares que, feito o bem e o mal, o amor e o ódio, o corpo e o espírito, o homem e a mulher, Deus e o diabo ou a canção de Siruiz e as canções lírico-guerreiras de Riobaldo, se encontraram, duelaram, dançaram e impulsionaram, durante todo o romance, e durante toda a saga sertaneja, a travessia do herói-jagunço e narrador da estória.

Mesmo com o passar do redemoinho, mesmo com o transpassar dos anos, Riobaldo guardaria na memória todos os sons indistintos do bulício que, à distância, ouvira e os detalhes do que enxergara, mirara e vira, imóvel, sem nada poder fazer, daquela janela, daquela torre, naquela rua:

... o Diabo na rua, no meio do redemunho... O senhor soubesse... Diadorim-eu queria ver - segurar com os olhos... Escutei o medo claro nos meus dentes... O Hermógenes: 
desumano, dronho - nos cabelões da barba... Diadorim foi nele... Negaceou, com uma quebra de corpo, gambetou... E eles sanharam e baralharam, terçaram. De supetão... $e$ só...

E eu estando vendo! Trecheio, aquilo rodou, encarniçados, roldão de tal, dobravam para fora e para dentro, com braços e pernas rodejando, como quem corre, nas entortações. ... O diabo na rua, no meio do redemunho... Sangue. Cortavam toucinho debaixo de couro humano, esfaqueavam carnes. Vi camisa de baetilha, e vi as costas de homem remando, no caminho para o chão, como corpo de porco sapecado e rapado... Sofri rezar, e não podia, num cambaleio. Ao ferreio, as facas, vermelhas, no embrulhável. A faca a faca, eles se cortaram até os suspensórios. ...O diabo na rua, no meio do redemunho... Assim, ah mirei e vi-o claro claramente: aí Diadorim cravar e sangrar o Hermógenes... Ah, cravou - no vão - e ressurtiu o alto esguicho de sangue: porfiou para bem matar! Soluço que não pude, mar que eu queria um socôrro de rezar uma palavra que fosse, bradada ou em muda; e secou: e só orvalhou em mim, por prestígios do arrebatado no momento, foi poder imaginar a minha Nossa Senhora assentada no meio da igreja... Gole de consolo... Como lá embaixo era fel de morte, sem perdão nenhum. Que engoli vivo. Gemidos de todo ódio. Os urros... Como, de repente, não vi mais Diadorim! No céu, um pano de nuvens... Diadorim! Naquilo, eu então pude, no corte da dôr: me mexi, mordi minha mão, de redoer, com ira de tudo... Subi os abismos... De mais longe, agora davam uns tiros, esses tiros vinham de profundas profundezas. Trespassei.

Eu estou depois das tempestades. (GSV, p. 610-611)

Depois das tempestades - e até durante uma delas, talvez a maior, a de maior consequência - Riobaldo muito refletiu sobre se podia ou poderia ter evitado a doideira na boiada e o trágico final de sua travessia como jagunço e chefe de jagunços. Na narração e na pergunta pensada e não feita a Diadorim, na véspera da morte do amigo e da amada, o angustiado e melancólico desejo de compreensão e controle sobre o tempo:

Tempo é a vida da morte: imperfeição. Bobices minhas - o senhor em mim não medite. Mas, sobre uns assuntos assim, reponho, era que eu almejava ter perguntado a Diadorim, na véspera, de noite, conforme quando com ele passeei. Naquela hora, eu cismasse de perguntar a Diadorim:

- "Tu não acha que todo o mundo é doido? Que um só deixa de doido ser é em horas de sentir a completa coragem ou o amor? Ou em horas em que consegue rezar?" (GSV, p. 603)

E, na resposta que jamais ouvira de Reinaldo e de Diadorim, intuía a única certeza possível sobre os rumos que tomaram suas vidas. Nem o amigo nem a amada pensariam no amor ou na fé para nortear esse momento de suas vidas e ditar regras ao destino:

Não indaguei. Mas eu sabia que Diadorim havia de me dar resposta: - “Joca Ramiro não era doido nenhum, Riobaldo; e ele, mataram...” (GSV, p. 604)

Aqui a estória se acabou. Aqui, a estória acabada. Aqui a estória acaba. (GSV, p. 616) - comentou o barranqueiro de rio ao narrar a lembrança do trágico momento em que ultimou o jagunço Riobaldo e abandonou de vez a jagunçagem. 
Pouco antes do desfecho trágico desse romance de guerra, de amor e de morte, porém, cruzado o Liso do Sussuarão e a caminho do Paredão, depois de ouvir, de madrugada, à meia-noite, o uivado inteiro de um cão, um cão mal-uivante ( $G S V$, p. 576), conforme o sim pelo não, um insone Riobaldo começava já a compreender o que regia e regeria seus atos e suas escolhas: (...) entendia que podia escolher de largar ido meu sentimento no rumo da tristeza ou da alegria - longe, longe, até ao fim, como o sertão é grande... (GSV, p. 576-577). E, desse entendimento, brotou o singular dístico, talvez os versos finais, pelo menos os finalmente lembrados e relembrados, em quadra incompleta, de sua última canção:

\title{
Remanso de rio largo... \\ Deus ou o demo, no sertão...
}

Assim Riobaldo narra o lírico e sinistro momento do qual brotaram esses seus últimos versos:

\begin{abstract}
Madrugada de meia-noite. A lua já estava muito deduzida, o morro e o mato misturados. Relanceei em volta. Todo o mundo dormindo. Só o chochôrro mateiro, que sai de debaixo dos silêncios, e um ô-ô-ô de urutau, muito triste e muito alto. Depois, ouvi o uivado inteiro dum cão. Os companheiros todos dormindo, acordado só eu, alevantado de noite. Pesou por diante de meu coração. Devi àquele cão mal-uivante? Idéia tristezinha, que me veio. Por que era que só eu tinha acordado, desoras, tão antes de todos?

Mas eu mesmo queria prosperar de olhos abertos, carecia. O que produzia, era eu aguentar até passar o arrocho no coração. Deus que me punia - que hora tem-ou o demo pegou a regatear? E entendi que podia escolher de largar ido meu sentimento: no rumo da tristeza ou da alegria - longe, longe, até ao fim, como o sertão é grande...

Arte que espiei arriba, levei os olhos. Aquelas estrelas sem cair. As Três-Marias, o Carretão, o Cruzeiro, o Rabo-de-Tatu, o Carreiro-de-São-Tiago. Aquilo me criou desejos. Eu tinha de ficar acordado firme. Depois, daí, vi o escuro tapar, de nuvens. Eu ia esperar, fazendo uma coisa ou outra, até o definitivo do amanhecer, para o sol de todos. Ao menos achei de tirar, do tôo da noite, esse de-fim, canto de cantiga: Remanso de rio largo... / Deus ou o demo, no sertão... (GSV, p. 576-577)
\end{abstract}

Esse entendimento, esse poder de compreensão no rumo da tristeza ou da alegria que lhe fora dado e destinado, de fato - por Deus, pelo diabo, pelo seu próprio inconsciente -, em dia-de-véspera ao trágico desfecho de sua travessia jagunça, poder que Riobaldo tinha conquistado por si e para si, admirando no céu as Três Marias, o Cruzeiro e o Carreiro-de-São-Tiago ${ }^{213}$, porém, não o impediria de cursar o estreito e escorregadio caminho "rodeado de água e de fogo" que o faria confrontar-se com o Hermógenes, e não

\footnotetext{
${ }^{213}$ ROOB, Alexander, in: O Museu Hermético - Alquimia \& Misticismo. GmbH: Taschen, 2006, pág. 564, denota: "São Tiago era o santo padroeiro dos médicos e dos alquimistas. Segundo a "Legenda Áurea”, ele venceu, em Espanha, "Hermógenes" ou "Hermes Trimegisto", o que o obrigou a administrar o seu saber oculto". Na própria Legenda Áurea (p. 561 a 563), vemos que Tiago não apenas venceu o mago Hermógenes, sua "arte mágica", como, salvando-o da ira de seus próprios demônios e "retribuindo o mal com o bem", deu-lhe seu próprio báculo e converteuo ao Cristianismo, no qual, "no temor a Deus", passou a se destacar e a realizar muitas "boas obras". Merece nota o fato de que o Hermógenes, convertido, foi buscar seus livros de artes mágicas e entregou-os para que fossem queimados, mas Tiago não os destruiu, ordenando apenas que fossem jogados ao mar. E o mar sempre devolve tudo à praia. "Estreito e escorregadio é o caminho rodeado de água e de fogo", afirma Roob ao rezar um hino alemão, que data de 1553, de louvor à São Tiago (p. 564). Câmara Cascudo, no Dicionário de Folclore Brasileiro (p. 180), relaciona o Carreiro de Santiago à via láctea: "Todas as almas devem atravessar o carreiro de Santiago no caminho do céu”.
} 
mudaria o curso do rio, não impediria as suas águas urucuianas de se encontrarem com as do São Francisco para, com elas, nelas, seguirem rumo ao mar e, misturados, antes de se lançarem a esse mar, de caírem, de afluírem vertiginosamente, em cachoeira e queda d'água, barranco abaixo.

Feito a mítica Uroborus novamente, do início ao fim e do fim ao começo, depois da queda, do embarrancar e desbarrancar, o rio largo volta a remansar. Riobaldo não prossegue nas armas nem na jagunçagem, retira-se. Casa-se com Otacília, seu amor de prata, herda suas fazendas e as do padrinho-pai, Coronel Selorico Mendes, vira - como previra a canção de Siruiz e os últimos versos de sua própria canção - remansado barranqueiro do São Francisco - remansado?... - e, num esforço comovente, tenta laboriosamente reconstruir, através da narração de sua própria estória e história, toda a experiência vivida, todo o caminho percorrido, buscando, pelos labirintos da memória, pelo gosto de especular ideias, encontrar o sentido de sua travessia, a lógica das coisas e dos sentimentos num sertão em que a lei é também o seu reverso: Deus ou o demo, no sertão...

Endossando a importância - na travessia do sertanejo e na interpretação do Grande sertão: veredas não apenas da canção de Siruiz, mas também dos versos e canções que Riobaldo compôs para dar sequência a ela, espelhando-a pelo avesso, encontramo-nos, ao final do romance - assim como em seu começo - com um barranqueiro-narrador supostamente remansado à margem do mais largo dos rios que é o rio do tempo, da memória e da estória. Contudo, retomando as lições de Heráclito, o rio já não é mais o mesmo, assim como suas águas, tudo se misturou, se mesclou e, hermeticamente, mercurialmente, se confundiu.

Benedito Nunes, em "O amor na obra de Guimarães Rosa"214, afirma que, em sua travessia, o jagunço Riobaldo conhece três espécies diferentes de amor: "o enlevo por Otacília, moça encontrada na Fazenda Santa Catarina, a flamejante e dúbia paixão pelo amigo Diadorim e a recordação voluptuosa de Nhorinhá, prostituta, filha daquela Ana Duzuza, versada em artes mágicas”. E o estudioso acrescenta: "São três amores, três paixões qualitativamente diversas, que chegam por vezes a interpenetrarem-se”. Mas, para Nunes, Otacília, forte como a paz, com quem ao final se casa, é a que exerce "um efeito purificador sobre a alma de Riobaldo", aquela que pacifica suas angústias.

Comparando o Grande sertão a $O$ Banquete, de Platão, e, mais precisamente, ao que chama de a “dialética ascensional” transmitida por Diotima a Sócrates, na qual Eros eleva-se, gradualmente, do sensível ao inteligível, do corpo à alma e da carne ao espírito, num perene esforço de sublimação do qual não se elimina os "estágios inferiores" - pois só por intermédio deles se pode atingir o "alvo superior" -, assim

${ }^{214}$ NUNES, Benedito, in: O dorso do tigre. São Paulo: Editora 34, 2009, p. 137-165. 
como a Amadis de Gaula, atribuindo a Riobaldo o papel de Amadis sertanejo e à Otacília o de Oriana, Nunes vê em Otacília um remanso, “a conversão do amor humano em amor divino, do erótico em místico”:

Para conquistar essa outra beleza, para alçar-se até aquela imagem da paz, que se assemelha aos remansos do Urucuia, e que dorme em sua alma como secreta reminiscência, de quando em quando despertada, Riobaldo deverá pagar tributo à sensualidade de Nhorinhá sensualidade que não o detém e que lhe serve de escala, de via de acesso em direção à Otacília.

(...) Dama inspiradora de Riobaldo, consoladora e mediadora em seu espírito de uma outra vida - vita nuova - cheia de calma e paz, apenas vislumbrada, Otacília mista de princesa e castelã, dona de territórios imaginários, perdura na alma como objeto ideal, fonte de permanente anelo e constante inspiração, como símbolo do termo onde finda a busca amorosa e o destino se completa. (2009: 139-140)

Se parássemos nossos estudos aqui, polarizando o carnal e o espiritual, Nhorinhá e Otacília, poderíamos, com o casamento entre Otacília e Riobaldo, aproximando céu e terra, pacificar o final do Grande sertão e da travessia do narrador jagunço, afirmando - como aparentemente, numa leitura simplificada, poderíamos afirmar que fora proposto no primeiro verso da terceira estrofe da canção de Siruiz e endossado no penúltimo dos versos finais do próprio Riobaldo - que, após as corredeiras, como tinha de ser, o largo rio se remansaria, cessaria a lida guerreira, a busca amorosa, e o destino se completaria, sublimando a cruzada heroica. Entretanto, para chegarmos a essa feliz conclusão, teríamos de deixar de lado o último verso da última canção riobaldiana - em quadra incompleta - e toda sua dúvida e complexidade dialética: deus ou o demo, no Sertão...

No Grande sertão, Riobaldo, muitas vezes, reclama aquilo que considera uma justa separação entre o bem e o mal, de modo que esses opostos pudessem se excluir um do outro, tornando mais claras as regras do confronto. Percebendo a impossibilidade dessa ou de outras tantas polarizações, o jagunço concluiria: esse mundo é todo misturado. O próprio Nunes afirma que há três caminhos amorosos no todo misturado sertão rosiano, não apenas dois, e Diadorim é a terceira via:

Diadorim, ambíguo, menino que é também menina, desperta a alma de Riobaldo, infundelhe o desassossego, toque de Eros, que mais tarde, nos longes do sertão, se converterá em amor. (...)

Diadorim, ser andrógino, é, ao mesmo tempo, divino e diabólico. É ele quem, ainda menino, ensina Riobaldo a ver a beleza que vai pelo mundo. Mas no instante em que ilumina a alma do companheiro, marca-lhe sombriamente o destino. Na amizade com Diadorim-menino estaria a antecipação daquele pacto com o demônio, que Riobaldo se decidiu a firmar. Pois na infância já se emaranham fios de incerta origem, que tecem a vida de um homem, em seu direito e avesso.

Diadorim é um outro modo de amor, incomparável com o de Otacília e de Nhorinhá - amor que tinha um quê de paradisíaco, de idílico, e algo de ameaçador, escondendo o encanto noturno e proibido de uma felicidade enganosa, que se esfumaçou, em meio ao sangue das guerras de vingança, como se evaporam as simulações do Maligno. Nele o divino e o 
diabólico são permutáveis e simbolizam dois momentos da aventura que se realiza no homem - o momento ancestral, do velho ser humano dividido, que permanece presa das forças elementares, materiais e sensíveis, e o momento por vir, que lentamente se prepara, da transformação do humano em divino, e em relação ao qual a vida constitui uma iniciação e uma aprendizagem. (2009: 155-161)

Assim como a canção de Siruiz não se apagou da memória de Riobaldo e o amor de Otacília jamais conseguiu extirpar por inteiro o de Nhorinhá ou o de Diadorim, o rio suposta ou temporariamente remansado não extirpa de si o fluir ou os meandros do caminho, correntes submersas, porvir de corredeira, nem exclui de suas águas as outras tantas, misturadas, de que bebeu até o lugar de sua quietude que, retomando Heráclito, é sempre provisória. O problema da existência de Deus ou do diabo - de Deus e do diabo - e o das relações entre o Bem e o Mal, pano de fundo de todo o romance, trilha sonora de todos os seus amores e de todas as suas dores, assim como caminhou até o último verso da incompleta e também última copla riobaldiana, bebendo de todos seus outros versos e também dos de Siruiz, vai até o remate de sua estória e travessia: Nonada. O diabo não há! É o que eu digo, se for... Existe é homem humano. Travessia. (GSV, p. 624)

Com esse desfecho, numa leitura mais com os pés na terra, poderíamos concluir que Riobaldo, no final de sua vida e trajetória, havia ficado mesmo mais sereno e pragmático, mais remansado. Agora, o jagunço se tornara fazendeiro, herdeiro da Fazenda São Gregório e casado com a herdeira da Fazenda Santa Catarina, e, arranchado, lastreado, amparado pelos conselhos de seu mestre Quelemén, protegido pelos seus jagunços de outrora transformados em vassalos, supostamente não precisaria mais se preocupar com correntezas e quedas d’agua, com tempos de seca ou de enchente, com as ambiguidades do passado ou os reveses típicos do sertão.

Afinal, Riobaldo derrubou o Hermógenes, limpou o sertão da jagunçagem, abandonou as armas, "renunciando aos altos poderes que o elevaram por um instante acima da própria estatura" - como afirmou Candido no "O homem dos avessos" - e se retirou, acompanhado por grande parte de seus fiéis, para se tornar um homem de bem. Contudo, isso não foi o bastante para o cessar de sua travessia. Se, no final da narração, num aparente rompante racional, numa suposta submissão à "megera cartesiana", Riobaldo afirma enfaticamente que o diabo não há, essa não é a primeira vez que isso acontece no romance. Em outras tantas vezes, ele tece essa afirmação para, logo em seguida, se contradizer e voltar atrás, mantendo viva a dúvida crucial sobre sua demoníaca existência ou não. Retomaremos apenas um desses momentos, que, aliás, remete-nos exatamente a essa "folga" vivida pelo jagunço aposentado, como lembrança de seu gosto pela especulação e de seu desejo de remansar, de ter sua aragem de descanso:

De primeiro, eu fazia e mexia, e pensar não pensava. Não possuía os prazos. Vivi puxando difícil de dificel, peixe vivo no moquém: quem mói no asp'ro, não fantasêia. Mas, agora, feita a folga que me vem, e sem pequenos dessossegos, estou de range rede. $E$ me inventei neste gosto, de especular idéia. O diabo existe e não existe? Dou o dito. Abrenúncio. Essas 
melancolias. $O$ senhor vê: existe cachoeira; e pois? Mas cachoeira é barranco de chão, $e$ água se caindo por ele, retombando; o senhor consome essa água, ou desfaz o barranco, sobra cachoeira alguma? Viver é negócio muito perigoso...

Explico ao senhor: o diabo vige dentro do homem, os crespos do homem - ou é o homem arruinado, ou o homem dos avessos. Solto, por si, cidadão, é que não tem diabo nenhum. Nenhum! - é o que digo. O senhor aprova? Me declare tudo, franco - é alta mercê que me faz: e pedir posso, encarecido. Este caso - por estúrdio que me vejam - é de minha certa importância. Tomara não fosse... Mas, não diga que o senhor, assisado e instruído, que acredita na pessoa dele?! Não? Lhe agradeço! Sua alta opinião compõe minha valia. Já sabia, esperava por ela - já o campo! Ah, a gente, na velhice, carece de ter sua aragem de descanso. Lhe agradeço. Tem diabo nenhum. Nem espírito. Nunca vi. Alguém devia de ver, então era eu mesmo, este vosso servidor. Fosse lhe contar... Bem, o diabo regula seu estado preto, nas criaturas, nas mulheres, nos homens. Até: nas crianças - eu digo. Pois não é ditado: "menino - trem do diabo"? E nos usos, nas plantas, nas águas, na terra, no vento... Estrumes. ... O diabo na rua, no meio do redemunho... (GSV, p. 26-27)

Riobaldo não está argumentando em defesa da inexistência do diabo ao seu interlocutor forasteiro, ele está tentando fazer isso a si mesmo, tentando convencer-se, e se contradizendo nessa tentativa, pois mesmo supostamente sem existir, mesmo sem nunca ter sido visto pelo narrador - e, como ele próprio afirma, se alguém devia de ver ou de ter visto o diabo, então, esse alguém seria ele mesmo, possível pactário, servidor vosso -, mesmo assim, logo na sequência, reafirma, de forma titubeante, a sua própria crença, quando narra que o diabo regula seu estado preto, nas criaturas, nas mulheres, nos homens. Até: nas crianças...

Nunes aponta que Riobaldo, ao dizer, ao final da narrativa do Grande sertão, que o que existe é homem humano, numa "feliz redundância poética", estaria suspeitando que "o humano contém só um dos lados da natureza do homem, e que a vida é [também] uma tentativa de travessia - para o outro lado, divino". (2009: 161). Nós acrescentaríamos que a tentativa de travessia do humano Riobaldo se dá, pelos crespos do homem, pelo homem dos avessos, não apenas pelo anseio do divino, mas também pelos desígnios do demoníaco - do daimônico - nele e em nós, as duas faces complementares do mistério: deus ou o demo, no sertão. Deus e o demo no sertão, remetendo a uma terceira onde ambas se misturam e se revertem. "O é e o não é geram-se um ao outro", reverbera, no sertão, onipresente, a voz do Tao Te Ching.

Afirma Candido (1991): “... o homem do sertão [Riobaldo] se retira na memória e tenta laboriosamente construir a sabedoria sobre a experiência vivida, porfiando, num esforço comovedor, em descobrir a lógica das coisas e dos sentimentos". E, de Arrigucci (1994), temos que "Riobaldo, ao repassar o vivido e sua paixão errante por Diadorim, se esquiva da violência mítica do demo que marcou sua existência, expondo-a à luz da razão. Isto faz da travessia desse herói problemático de romance, homem humano, um contínuo aprender a 
viver - a real dimensão moderna da obra-prima de Guimarães Rosa"215. Lendo as narrativas do herói, acompanhando seus passos e transformações, tentando imaginar como seria a audição da canção de Siruiz ou dos versos criados pelo próprio protagonista-narrador do romance em seus tempos de lírica jagunçagem, e, como ele próprio, tentando ouvir e não ouvindo - e, talvez por isso, feito a canção de "Sorôco, sua mãe, sua filha", ouvindo ainda mais - as canções que Diadorim não cantava - pois o timbre de sua voz cantada poderia denunciar sua feminilidade -, vamos sendo conduzidos sertão adentro em busca da tentativa da decifração de seus segredos, de seus mistérios, de seus cantos, e, como o próprio Riobaldo, nosso guia, vamos sendo seduzidos pela esperança de sair dele com uma compreensão, um entendimento um pouco maior de sua hermética e misturada concepção, de seus versos e reversos, de seus enigmas. Nesse sentido, Riobaldo e Sorôco se assemelham, ambos cantam pelo desejo de volta ao lar, e ambos nos encantam trazendo a nós o anseio de, com eles, também seguir e cantar.

“Em 'Sorôco...', como afirma Reinaldo (2005: 222), os companheiros de Ulisses não taparam os ouvidos. O eloquente herói não foi atado ao mastro. Saltaram nas águas. Mas o canto das sereias, que não vigorava certo, arrastou-os para a vida". Em Riobaldo e seu Grande sertão, em águas turvas ou claras, agitadas ou remansadas, a canção não só nos arrasta para a vida e para o lar, mas nos mostra que o lar é o universo, que o sertão é o mundo e que voltar para casa, muitas vezes, é partir para longe, é aceitar a Odisseia de perder-se, e é - aliás também como aconteceu com "Sorôco..." - seguir até onde a canção nos levar.

Este foi o mergulho a que se propôs, ao som e silêncio das canções presentes e entoadas no Grande sertão: veredas, nosso estudo. Esperamos ter tido algum êxito em nosso desejo de contribuir com novos pontos de vista e novas possibilidades de visão sobre o tema. Contudo, certos disso ou não - certos disso e não -, saímos também com mais uma lição jagunça aprendida. Da voz do próprio Riobaldo, narrador e guia desta travessia, faz-se importante lembrar que (...) só se sai do sertão é tomando conta dele a dentro... (GSV, p. 295). Sendo assim, seduzidos, sem cera nos ouvidos, pelo canto das sereias, abocanhados pela mítica Uroborus e relembrando que, não à toa, Guimarães Rosa principiou o Grande sertão: veredas - e a fala infindável de Riobaldo - com a palavra "Nonada" e o finalizou com o símbolo do infinito, desejamos a todos nós, com essa provisória finalização, um bom recomeço de travessia, afinal, ler e reler o Grande sertão: veredas é sempre o ler pela primeira - e primeva - vez. Odisseus. ${ }^{216}$

${ }^{215}$ Em resumo para o ensaio "O mundo misturado: romance e experiência em Guimarães Rosa", publicado em novembro de 1994. Fonte: https://pt.scribd.com/doc/65723983/DAvi-Arrigucci-Jr-O-mundo-Misturado-Romance-e-experiencia-em-Guimaraes-Rosa - acessado em 07.11.2016.

${ }^{216}$ Expressão usada por Guimarães Rosa, em carta datada de 31 de março de 1952 endereçada a Mário Calábria, revelando os aventureiros planos do autor de realizar uma viagem de "40 léguas" acompanhando uma "boiada brava" no sertão de Minas Gerais. Correspondência citada por COSTA, Ana Luiza Martins. "Veredas de Viator". João Guimarães Rosa, Caderno de Literatura Brasileira. Instituto Moreira Salles, $\mathrm{n}^{\circ} 20$ e 21, 2006, p. 29. 


\section{CONSIDERAÇÕES FINAIS}

Assaz o senhor sabe: a gente quer passar um rio a nado, e passa; mas vai dar na outra banda é num ponto muito mais embaixo, bem diversa do que em primeiro se pensou. Viver não é muito perigoso?

(Grande sertão: veredas, Guimarães Rosa) $)^{217}$

Numa orvalhada madrugada de maio, enquanto o frio fiava, o menino Riobaldo vê e ouve os jagunços de Joca Ramiro a se entreterem com a viola e o canto de Siruiz. A canção aquece a noite, traz alento para a lida e ânimo para a luta dos dias de um sertão em guerra. Noutra madrugada fria, agora da vida jagunça do próprio Riobaldo adulto, o herói, cansado da guerra e triste pela notícia da morte de Siruiz, é instruído de uma outra canção, "Olererê Baiana”, cantiga de se viajar e cantar, guerrear e cantar, canto que, como na teogonia hesiódica, cura os doentes - de corpo e de espírito - e revigora, reanima, para o árduo e infindável combate diário. Canções: desejo de retomar a voz das Musas, retornar às palavras cantadas que se irmanam aos mitos e que, restituídas aos seus sentidos originais, "repetem o processo de criação", como tratou Rosa, em seu “diálogo” com Günter Lorenz:

O bem-estar do homem depende do descobrimento do soro contra a varíola e as picadas de cobras, mas também depende de que ele devolva à palavra seu sentido original. Meditando sobre a palavra, ele se descobre a sim mesmo. Com isso, repete o processo de criação. (1991: 83)

Noutro momento da mesma conversa, abordando ainda o imprescindível meditar sobre as palavras, Rosa menciona sua criativa compulsão perfeccionista, sua obsessão pela busca da vera palavra: "Uma palavra, uma única palavra ou frase podem me manter ocupado durante horas ou dias." (1991: 79). Na sequência, minucioso, esclarece o seu método de criação e de inventiva apropriação da linguagem:

Nunca me contento com alguma coisa. Como já lhe revelei, estou buscando o impossível, o infinito (...) Primeiro, há meu método que implica na utilização de cada palavra como se ela tivesse acabado de nascer, para limpá-la das impurezas da linguagem cotidiana e reduzi-la a seu sentido original. Por isto, e este é o segundo elemento, eu incluo em minha dicção certas particularidades dialéticas de minha região [referindo-se a Cordisburgo e ao sertão mineiro], que são linguagem literária e ainda têm a marca original, não estão desgastadas e quase sempre são de uma grande sabedoria linguística. E também está à minha disposição esse magnífico idioma já quase esquecido: o antigo português dos sábios e poetas daquela época dos escolásticos da Idade Média, tal como se falava, por exemplo, em Coimbra. E ainda poderia citar muitos outros, mas isso nos levaria muito longe. (1991: 81).

${ }^{217}$ Grande sertão: veredas. 19a. ed. Rio de Janeiro: Nova Fronteira, 2001, p. 51. 
Fruto de longo convívio com a obra de Guimarães Rosa e, particularmente, com o Grande sertão: veredas, ponto culminante da capacidade inventiva do autor, esta dissertação, almejando o impossível e o intangível, propôs-se como uma minuciosa tentativa de decifração - ou de aprofundamento de leitura, de hermenêutico mergulho em busca de sentidos -, quadra a quadra, verso a verso, palavra a palavra, da canção de Siruiz e dos versos que Riobaldo fez para complementá-la. Para tanto, fazendo-se mister o respeito às vontades, leituras e interesses do autor, objetivamos dar voz não apenas ao caráter racional e lógico usuais ao trabalho dissertativo, mas também propiciar espaço ao intuitivo, ao simbólico, ao mítico ${ }^{218}$ e ao poético.

Concluímos, logo de saída, que o canto e as canções das escrituras rosianas são muito mais do que, numa primeira impressão, aparentam ser. Se tudo, nesta vida, é muito cantável, como afirma Riobaldo, constatamos que, como na Teogonia de Hesíodo, o canto, para Rosa, nunca é mera trilha sonora ou fundo musical para uma estória. Muito mais do que isso, ele a representa, a presentifica e a revela. Decifrados seus sons e silêncios, suas palavras cantadas, deciframos muito da narrativa e aproximamo-nos das intencionalidades do autor.

Confirmando as suspeitas de Arrigucci Jr. a respeito da canção de Siruiz, em "O mundo misturado", após profunda análise e minucioso exercício de debruçar-se sobre essa epifânica canção e sobre os versos e coplas de Riobaldo, apoiados na fortuna crítica do autor e em seus próprios depoimentos e apontamentos, pudemos, de fato, perceber e comprovar que neles se encontram não apenas o revelar e o desvelar do que de mais importante aconteceu com o herói durante sua travessia - comprovando seu caráter oracular e de "caroço" da narrativa -, mas também vislumbramos os ecos de muitos dos interesses e leituras de Rosa, com os quais suas canções e sua obra como um todo dialogam.

Reinaldo (2005: 223) afirma que as canções, na obra rosiana, adquirem diferentes contornos e "vistas em suas relações com a dita 'cultura erudita' ou em suas correspondências com o universo popular do sertão mineiro ganharão outros tantos significados". Concordando com isso, apoiados no acervo de leituras e apontamentos do autor, nos levantamentos de Sperber (1976) sobre a última biblioteca de Rosa, nos estudos de Hazin (1991) sobre a gênese do Grande sertão: veredas, nos levantamentos de Chevalier e Gheerbrant (2000) sobre os significados dos símbolos e na pesquisa da própria cultura e tradição sertanejas, mergulhamos em ambas as possibilidades de correspondências, e concluímos que, nos versos e canções do Grande sertão, além de uma recriação mítico-simbólica da paisagem e da tradição sertanejas do norte de Minas, e, além da profética antecipação da aprendizagem de Riobaldo durante suas andanças, idas e vindas, pelo sertão,

${ }^{218}$ REINALDO (2005: 223) traz uma definição de mito da qual nos valemos para a condução dessa pesquisa: "Mito não apenas como narrativa modelar, fixa, exemplar, que se inscreve racionalmente no contexto de uma dada comunidade. Mas como algo que está ligado ao inconsciente, aos sonhos, aos arquétipos. Como canal de comunicação do homem com uma esfera espiritual, sagrada." 
encontramos também indícios dos interesses mítico-religiosos do autor - tantas vezes já evidenciados em entrevistas e cartas - e pistas sobre muitos dos clássicos da literatura que lhe serviram de inspiração - como, aliás, tentamos evidenciar com as obras citadas neste estudo e que estão servindo de lastro para a análise comparada ora apresentada.

Ao aprofundar os estudos do sentido mítico que a linguagem rosiana assume - uma espécie de canal de comunicação do homem com o incognoscível, o metafísico e o sagrado -, damos voz e fazemos eco a uma citação de Gabriela Reinaldo, com a qual concordamos:

Um sagrado incessantemente remodelado pelas mãos do próprio homem, sujas de barro. Um
sagrado profanamente plasmado. Gastando as palavras do Rosa: “formulação intensificadora
e concretizante, de malhas para captar o incognoscível”. Algo que não se situa numa esfera
acima, mais alta. Mas que sendo formulação intensificadora e concretizante vive também na
linguagem do homem do sertão de Rosa. Homem que recria as palavras, remodela-as ao sabor
do contorno oral que a imagem e o pensamento sugerem. Que mantém com elas uma relação
não de arbitrariedade, mas de instantaneidade, de urgência, de necessidade. Que ainda é dado
ao espanto do nome, à maravilha do verbo, das palavras. Que as escuta cantar. (2005: 224)

Candido (1991) já dizia que "na extraordinária obra-prima Grande sertão: veredas há de tudo para quem souber ler" e que "cada um poderá abordá-la a seu gosto, conforme seu ofício", contudo, nessa magistral obra regida pelo "homem dos avessos" e pelo "princípio geral da reversibilidade" - aliás, tão bem tratados também por Candido -, nesse universo paradoxal e dialético que, como já dissemos, se inicia com o "Nonada" e se finaliza com o símbolo do infinito, e que, como afirmou Hazin (1991), "parece aprisionar entre o não-ser e o ser a fluência da 'estória' que, a exemplo das 'Mil e uma noites', reflete o fascínio exercido pela palavra sobre o criador que a deseja infinita", constatamos o quão difícil é ser categórico em qualquer afirmação demasiado polarizada.

Em Rosa e no seu Grande sertão, confrontando a máxima hamletiana, a conjunção alternativa parece ser trocada pela aditiva, tudo parece ser e não ser, poder e não poder, e, além do bem e do mal, aquilo que é facilmente se reverte em seu oposto que, aliás, paradoxalmente e de forma dialética, já era parte integrante de si, já trazia o tempo todo consigo.

Na voz do próprio Rosa a Lorenz: “... tudo: a vida, a morte, tudo é, no fundo, paradoxo. Os paradoxos existem para que ainda se possa exprimir algo para o qual não existem palavras.” (1991: 68). E, voltando à busca compartilhada com Rosa das veras palavras, num mundo no qual, aludindo Riobaldo, para muita coisa importante falta nome, tentamos ser cuidadosos com quaisquer tomadas de posições extremistas durante todo o percurso da elaboração deste trabalho de pesquisa, e manteremos este cuidado também nestas considerações finais. Aliás, um exemplo deste necessário cuidado diz respeito ao "caráter fáustico" do romance, do qual tanto tratamos neste estudo e ao qual retornaremos brevemente na sequência. 
Retomando depoimento de Rosa a Lorenz, no qual afirma que "Riobaldo não é Fausto"219, concordamos com Consuelo Albergaria - como, aliás, já apontamos no capítulo 4 -, quando ela aponta que o suposto pacto de Riobaldo não é apenas uma simples reedição do mito fáustico. "Riobaldo não é Fausto." - conclui Albergaria - "E nem poderia ser, uma vez que na tragédia de Goethe, o demônio, Mefistófeles, aparece visível e comprovadamente, dialogando e fechando o pacto com o protagonista, o que absolutamente não acontece em Grande sertão: veredas, em que o máximo que se poderia aceitar seria a permanência da dúvida.” (1977: 37). Vale relembrar, como, aliás, também já apontamos, que também Walnice Galvão denota que o que mais se aproxima da materialização do demônio no romance, configurando mais uma de suas tantas ambiguidades, é o "redemoinho" que dá origem à uma das frases chaves do romance e que lhe serve de epígrafe: O diabo na rua, no meio do redemunho. Para Galvão, "O diabo, algo concretizado e corporificado no meio de algo móvel e envolvente como o redemoinho é a imagem-mor do certo no incerto" (1972: 129).

Yudith Rosenbaum (2007), em seu “A batalha final: Riobaldo na encruzilhada dos fantasmas”, mesmo afirmando que Riobaldo, ao narrar os momentos que antecedem o trágico duelo entre Diadorim e o Hermógenes $^{220}$ - em particular o trecho que trata da alma que perdeu o corpo -, "parece confirmar o pagamento da alma ao diabo, que vem cobrar a chefia vitoriosa" (p. 110), ainda assim alimenta a polêmica em torno da questão da existência ou não do pacto no Grande sertão: veredas:

De um lado, Riobaldo precisa acreditar na possessão demoníaca para assim justificar seu pânico. De outro, o romance aposta na visão secularizada moderna, combatendo o arcaísmo que atribui materialidade ao diabo. Afinal, "tudo é e não é". A negação do demônio é o que também almeja Riobaldo do interlocutor culto, mas a tão comentada ambiguidade do texto tensiona essa hipótese iluminista e desencantada do mundo, levando ao limite o ser ou não ser hamletiano que habita o trágico Riobaldo. Não ser ou ser... tão? O narrador, longe de se caracterizar por uma dissimulação controlada, estaria à mercê de um conflito entre o eu e o outro, que o transcende. (2007: 114)

E Rosenbaum cita um outro trecho do desfecho trágico do romance para tratar das dúvidas do narrador a respeito dele mesmo como sujeito desejante, desconfiando de si como detentor da própria vontade, no qual a marca do homem cindido se faz clara:

(...) alguém se riu de mim, como que escutei. $O$ que era um riso escondido, tão exato em mim, como o meu mesmo, abafado. Donde desconfiei. Não pensei no que não queria pensar; e certifiquei que isso era idéia falsa próxima; e, então, eu ia denunciar nome, dar a cita: ...Satanão! Sujo!... e dele disse somentes - S... - Sertão... Sertão... (GSV, p. 607)

\footnotetext{
219 “(...) Riobaldo não é Fausto, e muito menos ainda um místico barroco. Riobaldo é o sertão feito homem e é meu irmão. Muitos de meus intérpretes se equivocaram (...) Riobaldo é mundano demais para ser místico, é místico demais para ser Fausto.” (LORENZ: 1991: 95),

220 "Quem era que me desbraçava e me peava, supilando minhas forças? - 'Tua honra... Minha honra de homem valente!... - eu me, em mim, gemi: alma que perdeu o corpo". (GSV, p. 610)
} 
Sendo assim, considerando as controvérsias e voltando a fazer referência aos estudos de Mazzari, vimos no romance rosiano também a possibilidade de "deslocar a história narrada da trilha fáustico demoníaca para a dimensão do aperfeiçoamento e da aprendizagem" (2010: 32) e mantivemos, durante todo o estudo, o pacto fáustico de Riobaldo como hipótese. Todavia, ainda citando Mazzari, para o trato aprofundado com o romance, não há como deixar o importante motivo fáustico e a face demoníaca de lado:

Se a face demoníaca - "cara de gente, cara de cão" 'que bruxuleia no início do Grande sertão é atribuída de imediato à crendice de um "povo prascóvio", mesmo assim o leitor pode ser remetido a uma esfera que talvez não seja coisa de nonada. Pois ainda que Riobaldo não duvide tratar-se apenas de uma aberração da natureza - muito distante, portanto, de algo como a face gorgônica da Medusa ou o olhar mortífero do basilisco - , a superstição popular parece tê-la concebido naquele âmbito que Mefistófeles, desprendendo-se do disfarce do cão e surgindo pela primeira vez diante de Fausto, diz constituir o seu elemento mais genuíno, isto é, o Mal: "Por isso, tudo a que chamais/ De destruição, pecado, o mal,/ Meu elemento é, integral" (vv, 1.342-4). (2010: 27-28)

E, para mantermos ainda mais viva a dúvida sobre a existência ou não do diabo - e, consequentemente, a ocorrência ou não do pacto -, no peculiar universo ficcional do Grande sertão, e, independentemente da inexistência concreta ou materializada do demônio - "imagem-mor do certo no incerto" -, endossar sua fundamental importância na travessia de Riobaldo, apontamos as semelhantes falas de Riobaldo e de um dos mais expressivos protagonistas da tradição fáustica, Adrian Leverkühn, do Doutor Fausto, de Thomas Mann, a respeito do assunto: "Quem crê no diabo, já lhe pertence”, afirma Adrian (MANN, p. 251), e Riobaldo lhe faz eco: $E$, mesmo, quem de si de ser jagunço se entrete, já é por alguma competência entrante do demônio. (GSV, p. 26). Por fim, não há como deixar de lado as palavras do próprio Rosa a Lorenz, reproduzindo o que diz ser um "provérbio sertanejo", para tratar desse modo tão singular, e tão afeito aos costumes do sertão, de se tratar do assunto: “O diabo não existe, por isso ele é tão forte”. (1991: 94). Fazendo eco às paradoxais palavras de Maria Cecília Marks:

(...) em Guimarães Rosa, e essa é uma distinção fundamental, o diabo não tem corpo, não aparece, não fala. E tanto se faz mais forte quanto o seu silêncio e a sua ausência são presenças persistentes ao longo da narrativa. Esse demônio brasileiro é também ardiloso, mas dono de outras artimanhas, age melhor no vazio e habita a dúvida, que perseguirá o protagonista por toda a vida. (2012: 94)

Outrossim, mesmo admitindo a classificação do Grande sertão: veredas como um romance de formação e da trajetória de Riobaldo estando “entre pacto demoníaco e aprendizagem”, como propôs Mazzari (2010), insistimos, ainda, como Utéza, que Guimarães Rosa sempre teve forte apreço pelo valor alquímico e místico de seus escritos, relacionando-os com as grandes obras literárias e as tradições filosóficas e religiosas do ocidente e do oriente que tratam dessa temática. E, sendo assim, apoiados na pesquisa do viés metafísico 
e na análise do caráter supra-humano - de tentativa de aproximação a outras esferas da existência, para além do bem e do mal - da obra rosiana, concluímos que a travessia de Riobaldo, aliás, como as peregrinações de Dante, de Parsifal e de Fausto, dentre outros heróis de nossa tradição literária com os quais o Grande sertão dialoga, é também um percurso iniciático. Nas palavras do próprio Rosa a Lorenz:

Escrever é um processo químico; o escritor deve ser um alquimista. Naturalmente, pode explodir no ar. A alquimia do escrever precisa de sangue do coração. Não estão certos, quando me comparam com Joyce. Ele era um homem cerebral, não um alquimista. Para poder ser feiticeiro da palavra, para estudar a alquimia do sangue do coração humano, é preciso provir do sertão... (1991: 85)

E, para embasar nossa opção por tratar a travessia de Riobaldo também como um caminho místicoiniciático ou "iniciatório", citamos, outra vez, Candido:

O comportamento dos jagunços não segue o padrão ideal dos poemas e romances de Cavalaria, mas obedece à sua norma fundamental, a lealdade; e não há dúvida que também para eles a carreira das armas tem significado algo transcendente, de obediência a uma espécie de dever. (1991: 301-302)

(...)

Daí o esforço para abrir caminho, arriscando perder a alma, por vezes, mas conservando a integridade do ser como de algo que se sente existir no próprio lanço da cartada. A ação serve para confirmar o pensamento, para dar certeza de liberdade.

"Ao que naquele tempo, eu não sabia pensar com poder. Aprendendo eu estava? Não sabia pensar com poder - por isso eu matava".

"Mas liberdade - aposto - ainda é só alegria de um pobre caminhozinho, no dentro do ferro de grandes prisões. Tem uma verdade que se carece de aprender, de encoberto, e que ninguém não ensina: o beco para a liberdade se fazer".

A vida perigosa força a viver perigosamente, tendendo às posições extremas a que podem levar a coragem, a ambição, o dever. Pelo menos duas vezes ocorre na fala do narrador um conceito que exprime este movimento, e que encontramos, quase com as mesmas palavras, nas "Considerações sobre o pecado, a dor, a esperança e o verdadeiro caminho", de Kafka, onde vem formulado assim: "A partir de um certo ponto não há mais retorno. Esse é o ponto que se precisa atingir". Riobaldo caminha para ele e o alcança através do pacto, que é ao mesmo tempo ascese (sob o aspecto iniciatório) e compromisso (sob o aspecto moral), confirmando a sua qualidade de jagunço. (1991: 308)

Como afirmou Hazin (1991), reverberando as vozes de tantos outros críticos, poetas e pensadores, concluir, de certa maneira, significa reencontrar a introdução. Atar duas pontas em busca da descrição de um almejado círculo perfeito. Introduzimos este trabalho de pesquisa com a proposta de descida aos órficos labirintos infernais e de escuta, sem ceras nos ouvidos, mas também, como Ulisses, atados ao mastro da precaução e da razão, do canto das sereias ora reapresentado na voz e versos de Siruiz e de sua canção. Propusemo-nos ao mergulho na oralidade e na musicalidade do Grande sertão de Rosa, com o necessário 
cuidado de não nos deixarmos sucumbir ao "alto mar"221 que representa suas linhas, sua linguagem e sua incomparável imaginação criadora. Esperamos ter realizado a contento nossa proposta.

Nossa expectativa é que este trabalho tenha cumprido o objetivo de contribuir para a revisão da importância do canto e, particularmente, da canção de Siruiz na interpretação de Grande sertão: veredas, trazendo nova luz e novos vislumbres e possibilidades de visão aos seus cifrados significados e sentidos e ao seu aspecto de chave de entendimento - de "caroço", como afirmou Moura - do romance.

No tocante à obra em análise, vislumbramos ainda a possibilidade de aprofundamento muito maior da pesquisa, com base no aporte teórico desenvolvido por Marcus Vinícius Mazzari, da condição de romance de formação do Grande sertão, todavia, devido à delimitação temática desta dissertação, o assunto não pode ser, aqui, melhor desenvolvido. Finalizando, percebemos, também, que a temática da canção e da musicalidade, em Guimarães Rosa, ainda está muito pouco estudada e que, portanto, sua pesquisa de maneira geral ainda se apresenta incipiente, projetando reais lacunas e espaços a serem preenchidos na fortuna crítica do autor.

Finalizamos estas considerações com as mais do que sábias palavras de Riobaldo a respeito do conhecimento e da necessária humildade que devemos, sempre, ter para com ele: Conto ao senhor é o que sei e o senhor não sabe; mas principal quero contar é o que não sei se sei, e que pode ser que o senhor saiba. $(G S V$, p. 245)

${ }^{221}$ CANDIDO, in "O homem dos avessos", trata como "navegação no mar alto" o "jorro de imaginação criadora na linguagem, na composição, no enredo, na psicologia" que se apresenta em Grande sertão: veredas (1991: 294) 


\section{BIBLIOGRAFIA}

ALBERGARIA, Consuelo. Bruxo da linguagem no Grande sertão: leitura dos elementos esotéricos presentes na obra de Guimarães. Rio de Janeiro, Tempo Brasileiro, 1977.

ALIGHIERI, Dante. A Divina Comédia (tradução de Ítalo Eugênio Mauro - Edição bilíngue). São Paulo: Editora 34, 2010.

A Divina Comédia (tradução e notas de Ítalo Eugênio Mauro - Edição de bolso com prefácio de Otto Maria Carpeaux). $1^{\text {a }}$ ed. São Paulo: Editora 34, 2009.

Vida Nova (tradução de Paulo M. Oliveira e Blasio Demétrio). Biblioteca Clássica vol.

XX. $3^{\text {a }}$ ed. São Paulo: Atena Editora, 1957.

ARAÚJO, Heloísa Vilhena de. O roteiro de Deus: dois estudos sobre Guimarães Rosa. São Paulo: Editora Mandarim, 1996.

ARRIGUCCI Jr., Davi. "O mundo misturado: romance e experiência em Guimarães Rosa”. In: Revistas Novos Estudos CEBRAP (40). São Paulo, outubro, 1994, p. 7-29.

ARROYO, Leonardo. A cultura popular em Grande Sertão: Veredas. Rio de Janeiro: José Olympio Editora, 1984.

BAKHTIN, M. M. Problemas da Poética de Dostoiévski. Trad. Paulo Bezerra. 1ª ed. Rio de Janeiro: Forense Universitária, 1981. . A cultura popular na Idade Média e no Renascimento: o contexto de François Rabelais.

São Paulo: Hucitec, 1999.

BAUMAN, Zygmunt. Modernidade Líquida. Rio de Janeiro: Jorge Zahar, 2001.

BÍBLIA DE JERUSALÉM. São Paulo: Edições Paulinas, 1986.

BIZZARRI, Edoardo \& ROSA, João Guimarães. João Guimarães Rosa: correspondência com seu tradutor italiano Edoardo Bizzarri - $3^{\mathrm{a}}$ ed. Minas Gerais: Editora UFMG \& Rio de Janeiro: Editora Nova Fronteira, 2003.

BRANDÃO, Junito de Souza. Dicionário mítico-etimológico. Petrópolis: Vozes, 2014. . Mitologia Grega. 20a ed. Petrópolis: Vozes, 2013, 3 v.

BURCKHARDT, Titus. Alquimia. Lisboa: Dom Quixote, 1991.

CAMPOS, Augusto de. "Um lance de 'dês' do Grande Sertão". In: COUTINHO, Afrânio (org.). Coleção fortuna Crítica: Guimarães Rosa. Rio de Janeiro: Civilização Brasileira, 1991.

CAMPOS, Haroldo de: Deus e o Diabo no Fausto de Goethe. São Paulo, Editora Perspectiva, 2008.

CANDIDO, Antonio: "Jagunços e mineiros de Cláudio a Guimarães Rosa." In: Vários escritos. São Paulo: Duas Cidades, 1977.

"O homem dos avessos". In: COUTINHO, Eduardo F. (org.) Coleção fortuna Crítica: Guimarães Rosa. Rio de Janeiro: Civilização Brasileira, 1991, p. 294-320. - Repr. Diálogo. São Paulo (8), nov. 1957, sob o título "O sertão e o mundo".

CASCUDO, Luís da Câmara. Vaqueiros e cantadores. São Paulo: Global, 2005.

Dicionário do folclore brasileiro, 12a ed. São Paulo: Global, 2005.

CHEVALIER, Jean \& GHEERBRANT, Alain. Dicionário de Símbolos, 15ª ed. Tradução: Vera da Costa e Silva. Rio de Janeiro: José Olympio Editora: 2000.

COIMBRA, Álvaro da Veiga, Noções de Numismática. SP. Secção Gráfica da Faculdade de Filosofia, Ciências e Letras da Universidade de São Paulo, 1965. 
COSTA, Ana Luiza Martins. "Veredas de Viator". João Guimarães Rosa, Caderno de Literatura Brasileira. Instituto Moreira Salles, no 20 e 21, 2006, p. 29.

COUTINHO, Eduardo F. (org.) Coleção fortuna Crítica: Guimarães Rosa. Rio de Janeiro: Civilização Brasileira, 1991.

Grande sertão: veredas - Travessias. São Paulo: Realizações Editora, 2013.

CUNHA, Euclides da. À margem da História. Org. por Rolando Morel Pinto. São Paulo: Cultrix, 1975.

DE SANCTIS, Francesco. Opere, a cura de Nicolò Gallo, Milano-Napoli: Riccardo Ricciardi Editore, 1961.

DE ROBERTIS, Domenico. Il libro della “Vita Nuova”. Firenze: Sansoni, 1970.

DE VARAZZE, Jacopo. Legenda Áurea - Vidas de santos. Tradução do latim, apresentação, notas e seleção iconográfica Hilário Franco Júnior. São Paulo: Companhia das Letras, 2003.

DOSTOIÉVSKI, Fiódor M.: Os irmãos Karamázov. São Paulo, Editora 34, 2008.

ESCHENBACH, Wolfram von. Parsifal (Tradução de A. R. Schmidt Patier). São Paulo: Antroposófica, 1995.

FREUD, S. “O Estranho” (1919). In: Obras Completas. Rio de Janeiro, Imago, 1976, V. XVII.

GALVÃO, Walnice N. A donzela guerreira - um estudo de gênero. São Paulo: Editora Senac, 1997.

As formas do falso - Um estudo sobre a ambiguidade no Grande Sertão: Veredas.

São Paulo, Perspectiva, 1988.

Senac, 1998.

“Ciclo da donzela guerreira”. In: Galos de outro saco. Ensaios críticos. São Paulo:

São Paulo: Cia. Das Letras, 2010.

GOETHE, Johann Wolfgang Von. Fausto I. (tradução de J. K. Segall). Apresentação, comentários e notas de Marcus Vinicius Mazzari. São Paulo: Editora 34, 2007 (edição revista e ampliada 2011).

. Fausto II. (tradução de J. K. Segall). Apresentação, comentários e notas de Marcus

Vinicius Mazzari. São Paulo: Editora 34, 2011.

. Os anos de aprendizado de Wilhelm Meister (tradução de Nicolino Simone Neto;

apresentação de Marcus Vinicius Mazzari e posfácio de George Lukács). 2a ed. São Paulo: Editora 34, 2009.

GOMES, Lindolfo. Contos Populares. Dias Cardoso \& Cia. Editora, Juiz de Fora, 1918.

HAZIN, Elizabeth. No nada, o infinito (da gênese do Grande sertão: veredas). São Paulo: Tese de Doutorado FFLCH-USP, 1991.

HEIDEGGER, Martin. Ser e tempo. $5^{\text {a }}$ ed. Petrópolis: Vozes, 1995.

HESÍODO. Teogonia - A origem dos deuses. Tradução e estudo de JAA Torrano. $7^{\mathrm{a}}$ ed. São Paulo: Iluminuras, 2009.

HILL, Amariles Guimarães, “Cara-de-Bronze”, in: Navegações - revista eletrônica Pucrs - v. 2, n. 2, p. 9194, jul./dez. 2009. Site: http://revistaseletronicas.pucrs.br/ojs/index.php/navegacoes/article/viewFile/6391/4657.

LAPLANCHE \& PONTALIS, Vocabulário da Psicanálise, trad. Pedro Tamen. $4^{\mathrm{a}}$ ed. São Paulo: Martins Fontes, 2001.

LIMA, Luiz Costa. “O sertão e o mundo: termos da vida”. In: Por que Literatura?. Petrópolis: Vozes, 1969, p. 71-97.

LORENZ, Günter. “Diálogo com Guimarães Rosa”. In: COUTINHO, Eduardo F. (org.) Guimarães Rosa. Rio de Janeiro: Civilização Brasileira, 1991, p. 62-97.

LUKÁCS, Georg. Posfácio de Os anos de aprendizado de Wilhelm Meister, Goethe, J. W. V. São Paulo: Editora 34, 2009, p. 581-601. 
MACHADO, Ana Maria. Recado do nome - Leitura de Guimarães Rosa à luz do nome de seus personagens. Rio de Janeiro: Nova Fronteira, 2003.

MANN, Thomas. Doutor Fausto - A vida do compositor alemão Adrian Leverkühn narrada por um amigo. Trad. Herbert Caro. Rio de Janeiro: Nova Fronteira (Saraiva de bolso), 2011.

MARKS, Maria Cecília. Fausto e a representação do Diabo na Literatura: Um estudo comparativo da tradição fáustica em Guimarães Rosa, Thomas Mann e Fiódor Dostoiévski. Tese de Mestrado FFLCH-SP, 2012.

MARTINS, Nilce Sant'Anna. O Léxico de Guimarães Rosa. São Paulo: Edusp, 2008 (3 edição revista e ampliada).

MARLOWE, Christopher: A história trágica do Doutor Fausto. Trad.de A. de Oliveira Cabral. São Paulo: Hedra, 2006.

MAZZARI, Marcus Vinicius. Apresentação de Os anos de aprendizado de Wilhelm Meister, GOETHE, J. W. V. São Paulo: Editora 34, 2009, p. 7-23.

“A segunda parte do Fausto: 'esses gracejos muito sérios' do velho Goethe”.

In: GOETHE, J. W. V. Fausto II. (tradução de J. K. Segall). Apresentação, comentários e notas de Marcus Vinicius Mazzari. São Paulo: Editora 34, 2011, p. 7-29.

. "Figurações do 'mal' e do 'maligno' no Grande Sertão: Veredas”. In: Revista

de Estudos Avançados, v.22, n.64, 2008, p. 273-290.

"Goethe e a história do Doutor Fausto: do teatro de marionetes à literatura

universal”. In: GOETHE, J. W. V. Fausto I. (tradução de J. K. Segall). Apresentação, comentários e notas de Marcus Vinicius Mazzari. São Paulo: Editora 34, 2007 (edição revista e ampliada 2011), p. 7 a 26.

Labirintos da Aprendizagem - Pacto fáustico, romance de formação e outros

temas de literatura comparada. São Paulo, Editora 34, 2010.

MENESES, Adélia Bezerra de. "Sob o signo de Hermes". In: Interpretações - Crítica Literária e Psicanálise, org. Cleusa Rios Passos e Yudith Rosenbaum (orgs.), São Paulo: Ateliê Editorial, 2014.

MOURA, Murilo Marcondes de. A canção de Siruiz. Texto ainda não publicado, gentilmente cedido pelo autor.

NUNES, Benedito. O dorso do tigre. São Paulo: Editora 34, 2009.

PATIER, A. R. Schmidt, in prefácio a ESCHENBACH, Wolfram von. Parsifal. $3^{\text {a }}$ edição. São Paulo: Editora Antroposófica: 2006.

PLATÃo, Timeu. In: Diálogos. Trad. Carlos Alberto Nunes. Belém: Universidade Federal do Pará, 1977.

PROENÇA, M. Cavalcanti. Trilhas no Grande Sertão. Rio de Janeiro, José Olympio Editora, 1959.

QUERINO, Manuel, A Bahia de Outrora, p. 95, Livraria Progresso Editora, Salvador, 1955.

REINALDO, Gabriela. Uma cantiga de se fechar os olhos... - Mito e música em Guimarães Rosa. São Paulo: Annablume; FAPESP, 2005.

RONCARI, Luiz: O Brasil de Rosa: mito e história do universo rosiano - o amor e o poder. São Paulo: Editora UNESP, 2004.

RÓNAI, Paulo. "Rondando os segredos de Guimarães Rosa". In: ROSA, João Guimarães, Manuelzão e Miguilim, 11ª ed. São Paulo: Editora Nova Fronteira, 2001, p. 17-25.

. "Três motivos em Grande sertão: veredas". In: ROSA, João Guimarães Grande sertão:

veredas (introdução à obra). 19a ed. Rio de Janeiro: Nova Fronteira, 2001, p. 15-20..

ROOB, Alexander. O Museu Hermético - Alquimia \& Misticismo. GmbH: Taschen, 2006.

ROSA, João Guimarães. A boiada. Rio de Janeiro: Nova Fronteira, 2011.

Grande sertão: veredas. 19a ed. Rio de Janeiro: Nova Fronteira, 2001. 
Guimarães Rosa - Obra Completa. Rio de Janeiro: Nova Aguilar, 1994. Manuelzão e Miguilim. 11 $1^{\mathrm{a}}$ ed. Rio de Janeiro: Nova Fronteira, 2001. Primeiras estórias. $1^{a}$ edição especial. Rio de Janeiro: Nova Fronteira, 2005. Sagarana. 55a impressão. Rio de Janeiro: Nova Fronteira, 2001.

ROSENBAUM, Yudith. "Guimarães Rosa e o canto da Desrazão". Revista Ângulo (Lorena), v. 1, 2008, p. $50-60$.

"A batalha final: Riobaldo na encruzilhada dos fantasmas". Revista Literatura e

Sociedade, n. 10, 2007-2008, p. 136-147. Versão on-line. Disponível em: http://www.revistas.usp.br/ls/article/view/23615/25651

ROSENFIELD, Kathrin H. Grande sertão: veredas - Roteiro de leitura. São Paulo: Ática, 1992. Os descaminhos do Demo - Tradição e ruptura em Grande sertão: veredas. Rio de Janeiro: Imago Editora \& São Paulo: Edusp, 1993.

SCHWARZ, Roberto. "Grande Sertão e Dr. Faustus". In: A sereia e o desconfiado. Rio de Janeiro, Civilização brasileira, 1965.

SHAKESPEARE, William. Hamlet (tradução de Millôr Fernandes). Porto Alegre: L\&PM, 2012.

SOBRINHO, João Batista Santiago. "A percepção Viggiana e líquida do sertão". In: Apresentação da $4^{a}$ edição de VIGGIANO, Alan. Itinerário de Riobaldo Tatarana - Geografia e Toponímia em Grande Sertão: Veredas, $4^{\mathrm{a}}$ edição, Belo Horizonte: Editora Crisálida, 2007, p. 7-12.

SPERBER, Suzi F., Cosmos e Caos - Leituras de Guimarães Rosa. São Paulo: Livraria Duas Cidades, 1976. TORRANO, Jaa. "O mundo como função de musas". In: HESÍODO. Teogonia - A origem dos deuses. $7^{\mathrm{a}}$ ed. São Paulo: Iluminuras, 2009.

TZU, Lao. Tao Te Ching. Trad. Waldéa Barcellos a partir de tradução americana de Stephen Addiss e Stanley Lombardo, com introdução de Burton Watson. São Paulo: Martins Fontes, 2002.

UTÉZA, Francis. João Guimarães Rosa: Metafísica do Grande Sertão; tradução: José Carlos Garbuglio. São Paulo: Editora da Universidade de São Paulo, 1994.

VASCONCELOS, Sandra Guardini Teixeira. "Sertão e memória: as cadernetas de campo de Guimarães Rosa". In: ROSA, João Guimarães. A boiada. Rio de Janeiro: Nova Fronteira, 2011.

VIGGIANO, Alan. Itinerário de Riobaldo Tatarana - Geografia e Toponímia em Grande Sertão: Veredas, $4^{a}$ edição, Belo Horizonte: Editora Crisálida, 2007.

WISNIK, José Miguel. "Recado da viagem”. In: Scripta - Revista de Pós-Graduação em Letras e do Cespuc - Edição Especial do Seminário Internacional Guimarães Rosa; v. 1, nº 1. Belo Horizonte: PUC Minas, 1997, p. 160-170. 